\title{
Gezondheid en niet werken : een vergelijkend onderzoek naar gezondheid en leefwijze van werkloze, arbeidsongeschikte, vervroegd gepensioneerde en werkende mannen
}

Citation for published version (APA):

van Horst, F. G. E. M. (1988). Gezondheid en niet werken : een vergelijkend onderzoek naar gezondheid en leefwijze van werkloze, arbeidsongeschikte, vervroegd gepensioneerde en werkende mannen. [, Maastricht University]. Rijksuniversiteit Limburg. https://doi.org/10.26481/dis.19881103fh

Document status and date:

Published: 01/01/1988

DOI:

10.26481/dis.19881103fh

Document Version:

Publisher's PDF, also known as Version of record

Please check the document version of this publication:

- A submitted manuscript is the version of the article upon submission and before peer-review. There can be important differences between the submitted version and the official published version of record. People interested in the research are advised to contact the author for the final version of the publication, or visit the DOI to the publisher's website.

- The final author version and the galley proof are versions of the publication after peer review.

- The final published version features the final layout of the paper including the volume, issue and page numbers.

Link to publication

\footnotetext{
General rights rights.

- You may freely distribute the URL identifying the publication in the public portal. please follow below link for the End User Agreement:

www.umlib.nl/taverne-license

Take down policy

If you believe that this document breaches copyright please contact us at:

repository@maastrichtuniversity.nl

providing details and we will investigate your claim.
}

Copyright and moral rights for the publications made accessible in the public portal are retained by the authors and/or other copyright owners and it is a condition of accessing publications that users recognise and abide by the legal requirements associated with these

- Users may download and print one copy of any publication from the public portal for the purpose of private study or research.

- You may not further distribute the material or use it for any profit-making activity or commercial gain

If the publication is distributed under the terms of Article 25fa of the Dutch Copyright Act, indicated by the "Taverne" license above,

Download date: 26 Apr. 2023 


\section{GEZONDHEID EN NIET WERKEN}

Een vergelijkend onderzoek naar gezondheid en leefwijze van werkloze, arbeidsongeschikte, vervroegd gepensioneerde en werkende mannen.

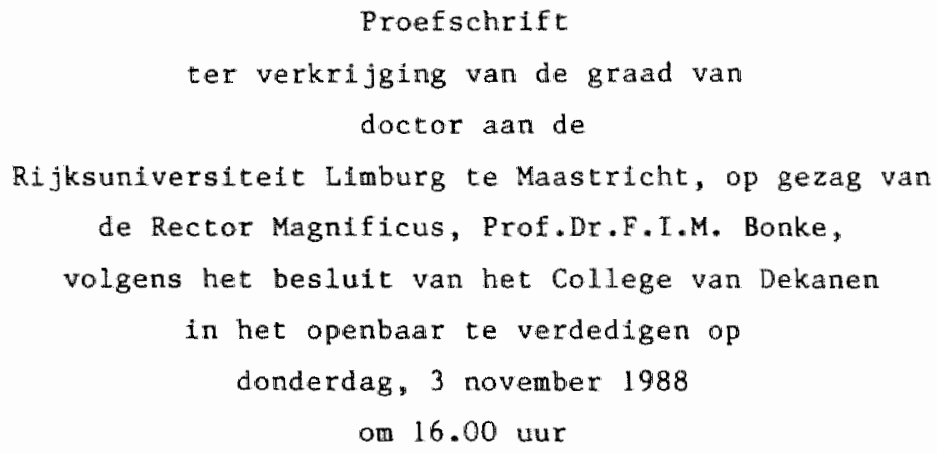



Promotores

Co-promotor

Beoordelings-

commissie
: Prof.Dr.H. Philipsen

Prof.Dr.C.A. de Geus

: Dr.F.J.N. Ni jhuis

: Prof.Dr.J.A. Knottnerus, voorzitter Mw.Prof.Dr.M.J. Drop

Mw.Dr.H.S. Merens-Riedstra

Prof.Dr.J. Persoon

Praf.Dr.J. van der Zee 
Manuscript:

Trudie Seegers

Ine siegelaer-Gerardu

Jim Tatipata

Adviezen:

Trudle Seegers

Oms 1ag:

Guus van Rooy

Lay-out:

Guus van Rooy

Trudie Seegers

Druk:

Ben Meerstad

Het verschijnen van dit proefschrift werd financieel mogelijk gemakt door een bijdrage van de Koninklijke Nederlandse Papierfabrieken nv en de Koninklijke Sphinx nv. 
Aan mijn vader $t$, mijn moeder, Anne, Klaske, Bregje en Jorn 
$-6-$ 
2. WERKENDEN EN NIET WERKENDEN

2.1 Inleiding 18

2.2 De veranderde verhouding tussen werkenden 18

2.3 De beroepsbevolking naar geslacht en leeftijd 22

2.4 Werklozen, arbeidsongeschikten en vervroegd 23 gepeasiomeerden vanaf 1971

2.5 Enkele kenmerken van niet werkenden 27

$\begin{array}{ll}2.5 .1 \text { Inlelding } & 27\end{array}$

2.5.2 Duur niet werken 28

2.5.3 Leeftijd en niet werken 31

2.5 .4 Leeftijd en duur niet werken 32

2.5 .5 Verdeling niet werkenden naar provincie 34 en social-economische klasse

$\begin{array}{lll}2.6 & \text { Samenvatting } & 37\end{array}$

3. NIET WERKEN EN GEZONDHEID

3.1 Inleiding. 39

3.2 Ongezondheid als oorzaak van niet werken 40

3.2.1 Inleiding 40

3.2.2 Verborgen werklozen onder arbeidsongeschikten 41

3.2.3 Verborgen arbeldsongeschikten onder werklozen 44

3.2.4 Verborgen arbeldsongeschikten onder vervroegd 45 gepensioneerden

3.2 .5 Ongezonde werkenden 48

3.3 Ongezondheld als gevolg van nlet werken 49

3.3.1 Inielding. 49

3.3.2 Arbeldsongeschikten 50

3.3.3 Verwroegd gepensioneerden 52

3.3.4 Werklozen 53

3.4 Gezondheidsmetingen onder niet werkenden 59

3.5 Conclusies en samenvatting 60 
4. PROBLEEMSTELITMG, HYPOTHESEN EN ORERATIOMALISATIE

4.1 Inleldang

4. 2 Overwegingen die rlchting geven an het onderzoek

4.3 De probleemstelling en omschrijving van de begrippen

4. 4. Hypothesen

4.4.1 Gezondheld

4.4.2 Gezondheidsopvattingen 75

4.4.3 Riskante gewoonten 79

4.4.4 Participatie 82

4.5 Operationalisatie 83

4.5.1 Gezondheild 83

4.5.2 Gezondheldsopvattingen 86

4.5.3 R1skante gewoonten 87

4.5.4 Partic1patie 87

4.6 Samenvatting 87

5. METHODEN EN POPULATIES

5.1 Inleiding 89

5.2 Methoden van onderzoek 89

5.2 .1 Het panelonderzoek 89

5.2 .2 Het praktijkpopulatie onderzoek 91

5.3 De populaties 9.4

5.3.1 Het panelonderzoek 95

5.3.2 De praktifkpopulatie 101

5.4 Toetsing van verschilien 107

5.5 Samenvating 110

6. AFSLUITING DEEL I 111

DEEL II: GEZONDHEID EN GEZONDHEIDSOPVATTINGEN

7. INLEIDING DEEL II $\quad \$ 14$

8. GERAPPORTEERDE GEZONDHEID EN GEZONDHEIDSOPVATTINGEN

8.1 Inlejding 116

8.2 Een onderlinge vergelljking van niet werkenden 116 naar gezondheid

8.3 Een onderlinge vergelijking van niet werkenden 118

8.4 Een vergelifking van werkenden en niet 119

8.5 Een vergelifking van werkenden en niet 120

$\begin{array}{ll}\text { 8.6 Werkenden naar gezondheidsopvattingen } & 121\end{array}$

8.7 Samenvatting 126 
9. GEZONDHETD, VASTGESTELD DOOR HUISARTSEN

9.1 Inleiding 128

9.2 De probleemlijst 130

9.2.1 Verdeling naar wel of niet aanwezig zijn van 130 problemen

9.2.2 Verdeling naar aantallen problemen 131

9.2.3 De verhouding tussen actieve en inactieve problemen 131

9.2.4 Verdeling van problemen naar componenten 132

9.2.5 Verdeling van problemen naar ICPC hoofdstukken 133

9.2.6 Verdeling van actieve en inactieve problemen 135 naar ICPC hoofdstukken

9.2.7 Een inhoudelijke vergelijking van psychosociale problemen van niet werkenden en werkenden

9.3 Contactregistratie huisarts patiënt 137

9.4 Conclusies en samenvatting 138

10. CONSISTENTIE VAN DE GEZONDHEIDSMETING

10.1 Inleiding 141

10.2 Gezondheid in $1981 \quad 142$

10.3 Gezondheid als clustervariabele 144

10.4 Het gezondheidsprofiel van werkenden en 146

10.5 Conclusies en samenvating 151

11. CONCLUSIES EN DISCUSSIE 153

DEEL III： LEEFWIJZE

$\begin{array}{ll}\text { 12. INLEIDING DEEL III } & 157\end{array}$

13. RISKANTE GEWOONTEN EN HET OORDEEL OVER DE EIGEN LEEFWIJZE 13.1 Inleiding 158

13.2 Een onderlinge vergelljking van niet werkenden 159

naar riskante gewoonten en oordeel over de eigen leefwijze

13.3 Een vergelijking nar riskante gewoonten en oordeel 160 eigen leefwijze van werkenden en niet werkenden

13.4 Conclusies

13.5 Samenvatting 164

14. PARTICIPATIE

14.1 Inleiding 166

14.2 Een anderlinge vergelijking van niet werkenden 167

naar participatie
14.3 Een vergelijking naar participatie van werkenden 168 $\begin{array}{ll}\text { en niet werkenden } & 170 \\ \text { Conclusies } & 171\end{array}$

$\begin{array}{lll}14.4 & \text { Conclusies } & 170 \\ 14.5 & \text { Samenvatting } & 171\end{array}$ 
17. EEN TRANSVERSALE ANALYSE

17.1 Inleiding 179

17.2 Gezondheld en gezondheidsopvattingen 180

17.2 .1 Gezondhe1d 180

17.2.2 Gezondheldsopvattingen 181

17.3 Rlskante gewoonten en oordeel eigen leefwije 182

17.4 Particlpatie 183

17.5 Conclustes 184

17.6 Samenvatting 188

18. EEN LONGITUDIMALE ANALYSE

18.1. Inlelding 189

18.2 Arbeidsongeschikten en werkenden 191

18.2.1 Gezondheid 191

18.2.2 Gezondheidsopvattingen 192

18.2 .3 Riskante gewoonten en oordeel eigen leefwijze 193

$\begin{array}{ll}18.2 .4 \text { Partlelpatie } & 194\end{array}$

18.3 Werklozen en werkenden 195

18.3.1 Gezondheld . 195

18.3.2 Gezondheidsopvattingen 196

18.3.3 Riskante gewoonten en oordeel eigen leefwijze 197

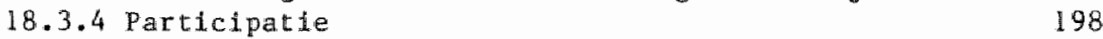

18.4 Conclustes 199

18.5 Samenvatting 201

19. CONCLUSIES EN DISCUSSIE 203

DEEL V: AFSLUTTHO

20. CONCLUSTES EN NAEESCHOUHING 211

21. SAMENWATTWG 223

$\begin{array}{lr}\text { SUMARY } & 230\end{array}$

LITERATUUR $\quad 239$

$\begin{array}{ll}B I J L A G E N & 247\end{array}$

$\begin{array}{ll}\text { DANKWOORD } & 255\end{array}$

$\begin{array}{lr}\text { CURRICULUM VITAE } & 262\end{array}$ 


\section{Introductie}

Met de voorliggende studie willen we een bijdrage leveren aan de discussie over de gezondheid en de leefwijze van nitet werkende en werkende mannen van Nederlandse rationaliteit in de leeftijd van 21 tot 65 jaar. De niet werkenden die in dit onderzoek centraal staan zijn arbeldsongeschikten, werklozen en vervroegd gepensioneerden.

De term "niet werkenden" impliceert dat mannen die tot ến van deze categorieën behoren en (al dan niet deeltijds) betaalde arbeid verrichten, buiten het onderzoek vallen. Onder arbeidsongeschikten verstaan we de niet werkenden die onder een van de volgende arbeldsongeschiktheidswetten vallen: WAO, AAW of ABP-lnwaliditeltspensioen. Werklozen zijn al degenen die geen betaalde arbeid verrichten, een ultkering krijgen vanwege het werkloos $z i j n$, en actief betaald werk zoeken. Onder vervroegd gepensioneerden verstaan we al degenen die voor hun 65e jaar met werken gestopt $z i j n$ vanwege een vervroegde uittredingsregeling, functioneel leeftijdsontslag, rentenierschap of vroege pensionering vanwege tropenjaren.

Herkenden, tenslotte, zijn al diegenen die betaalde arbeid verrichten, als zelfstandige of in loondlenst, zonder onder een van vorenstatande voorzieningen te vallen. Arbeidsloos bestaan ofwel het ontbreken van betaalde arbeid vormt het gemeenschappelijk kenmerk van arbeidsongeschikten, werklozen en vervroegd gepensioneerden.

Gelet op de onderscheiden oorzaken van het nlet werken van genoemde categorieën, en gelet op de verschillende voorzleningen waaronder deze categorieën vallen, mogen we veronderstellen dat zij geenszins homogeen zijn. Ziekte of gebrek 1 igt ten grondslag aan het arbeidsongeschikt zijn. De status van werkloze wordt verkregen door het niet (meer) hebben van een betaalde arbeldsplaats. De oorzaak van vervroegde penslonering is tweeërlel: het berelken van de pensioengerechtigde leeftijd v68r het 65 e levensjaar (bijwoorbeeld ambulancepersoneel), dan wel vervroegde ulttreding conform daartoe bestaande regelingen. 
Afhankelljk van de voorzlening warvan nlet werkenden gebrulk (moeten) maken, varlexten voor hen de financièle consequenties en de beleving van het wegvallen van betallde arbeid.

Dok wat betreft soclaal-demografische varlabelen blijken er onderlinge verschilen: wat leeftjd betreft vormen werklozen naar verhouding de Jongste en vervroegd gepensioneerden uiteraard de oudste categorie, terw1jl de arbeldsongeschikten een tussempositie innemen die dichter bif de vervroegd gepensioneerden dan bij de werklozen ligt.

Onderlinge vergelijking tussen de drie categorleën niet werkenden naar gezondheid en leefwifze ontbreken nagenoeg, terwijl het om meer dan Eén reden van belang is te weten of ze hierin onderling verschillen. Wat het onderscheid tussen werkiozen en arbeidsongeschikten betreft wordt door sommigen gesteld dat dit analytisch en irrelevant is. Deze bewering vloeit voort uit de constatering dat in bedrijfstakken waar een daling optreedt van de werkgelegenheid, een toename gesignaleerd wordt wan WAO-uitkeringsgerechtigden. Dit leidt tot de veronderstelling dat binnen de categorie arbeidsongeschikten een grote groep verborgen werklozen aanwezig is. Een aantal andere auteurs bestrijdt dit en stelt dat werklozen en arbeldsongeschikten geen onderling uitwisselbare categorieën vormen.

Daarnaast vinden we in recente literatuur sterke indicaties dat onder werklozen een deelcategorle verborgen arbeldsongeschikten schuil gaat. Eveneens wordt gesuggereerd dat de teruggang in toetreding tot de arbeidsongeschiktheldsregelingen het gevolg is van een sterke toename van het antal mensen dat gebruik makt van vervroegde uittredingsregelingen.

De tegenstrijdige ultspraken over de gezondheid van werkiozen, arbeldsongeschikten en vervroegd gepensioneerden heeft ons ertoe gebracht in dit onderzoek de gezondheid van deze drie categorieën onderling en met die van werkenden te vergelijken. Zoals gesteld hebben we ook aandacht besteed aan de leefwijze. Niet zelden wordt in de literatuur naar voren gebracht dat gedwongen nlet werken aanzlenlijke gevolgen heeft woor het dagelijks leven, onder meer een verlies van sociale contacten en een toename van voor de gezondheid riskante gedragingen. cok hierowtrent kan het hier te rapporteren onderzoek meer inzicht verstrekken. 
In dit onderzoek zullen we $66 \mathrm{k}$ ingaan op de samenhang tussen enerzijds de duur van het niet werken en anderzijds de gezondheid en de leefwijze. De laatste jaren heeft zich immers een nieuwe dimensie van het werkloosheidsprobleem aangediend, namelijk de toenemende duur van het werkloos zijn. In 1980 was rulm $30 \%$ van de werklozen langer dan ckn jaar zonder werk; vijif jaar later was dit bij meer dan de helft het geval. De kans om weer aan de slag te gaan blijkt trouwens steeds kleiner te worden naarmate de werkloosheid langer duurt; dit verschijnsel is wel eens kernachtig aangeduld met de zinsnede "werklozen worden werklozer".

De cijfers over werkhervatting van arbeidsongeschikten geven evenmin een opwekkend beeld: tien jaar na intrede in de arbeldsongeschiktheidswet heeft slechts é̉n vijfde het werk hervat. Van herintreding van vervroegd uitgetredenen lijkt geen sprake, hetgeen conform de bedoeling is van regelingen inzake vervroegde wittreding.

De afgelopen jaren is dan ook een discussie op gang gekomen over de effecten van langdurige werklooshejd en meer op de achtergrond over de effecten van langdurige arbeidsongeschiktheid op de gezondheid en de leefwijze. Op deze belangrijke vraag zijn we ook in dit onderzoek ingegaan door werklozen en de overige twee categorieën gedurende twee jaar in de tijd te volgen. Gedwongen verlies van betaalde arbeid zou de structuur van het dagelijks leven dusdanig kunnen verstoren dat de kans op voor de gezondheld riskante gewoonten en op een toenemend sociaal isolement aanzienl1 jk vergroot wordt.

Over de leefsituatie van arbeidsongeschikten is immiddels een en ander bekend. Opvallend is dat voor hen niet zozeer het leven met een aandoening, als wel het leven zonder werk een overheersend negatieve rol. speelt.

Over werkloosheid en de gevolgen hilervan voor het dagelifks leven is in Nederland pas de laatste Jaren op beschelden schal gepubliceerd. Dit is verbazingwekkend, vooral als wen zich realiseert dat er in ons land, vergeleken met andere landen in West-Europa, relatief veel werklozen en arbeldsongeschikten zijn. Publicaties betreffen veeleer arbeidsongeschiktheld en werkloosheid dan arbeidsongeschikt en werkloos zijn. Het aantal publicaties over vervroegd gepensioneerden is zeer gering. Omdat de definiëring van niet werkenden per land blifkt te verschillen, evenals hun social-economische positie, zijn onder- 
zoekstesultaten van elders niet zonder weer geldig voor de Nederlandse situatle.

Meer inzicht in de gezondheld en de leefwijze van niet werkenden is ook van belang omdat het grote aantallen mensen betreft. Wanneer we ze bif elkaar optellen, blifkt het om bijna anderhalf miljoen mensen te gaan. Van de gereglstreerde werklozen, arbeldsongeschikten en vervroegd gepensioneerden behoort ruim $70 \%$ tot het mannelifk geslacht.

Anno 1987 bedroeg het aantal werklozen in Nederland officieel 640.000 en het aantal arbeidsongeschikten bijna 700.000. Afhankelijk van de definitie van werkloosheld $11 \mathrm{gt}$ het antal hoger of lager.

Het aantal vervroegd gepensioneerden onder de 65 jaar blijkt moeilijk vast te stellen; het werd anno 1985 geschat op 160.000 personen: circa 90.000 vervroegd uitgetredenen (VUT-ers) en 70.000 mensen voor wie wroege pensionering geldt. In 1983 waren de officiële aantallen van werklozen en arbeidsongeschikten hoger dan in 1988, terwijl het aantal vervroegd gepensioneerden van destijds aanzienlijk lager geschat wordt. De van overheidswege herziene definlëring van werkloosheid zou mede van invloed zijn op de officièle daling van het aantal werklozen. Voorlopig is er geen reden om aan te nemen dat het aantal werklozen dan wel arbeidsongeschikten belangrijk werder zal dalen.

Het belang van dit onderzoek kan ook begrepen worden tegen de achtergrond van de discusie over de tweedeling van de samenleving: zij die werken en $z i j$ die nlet werken. Van een gebroken samenleving zou (nog) geen sprake $z i j n$. Nlettemin waarschuwt het Soclaal en Cultureel Planbureau ervoor, dat werkloosheld en arbeidsongeschiktheid niet verwarloosd mogen worden als veroorzakers van soclale en culturele verschillen. In het kader van het voorgaande kunnen we hieraan toevoegen: als. mogelljke veroorzakers van verschillen in gezondheid. Arbeid is niet alleen van economisch, maar zeer zeker ook van sociaal belang; arbeid wordt zelfs omschreven als een hoofdcategorie van menselijke zelfinterpretatie en zelfwaardering, hetgeen betekent dat iemands persoon$11 \mathrm{jk}$ en matschappelijk prestige primair bepaald wordt door de vraag of, en welke betalde arbeld verricht wordt.

We zullen daarom in deze verhandeling niet alleen ingaan op de vraag of de drie categorieën niet werkenden onderling verschillen, maar ook 
in hoeverre deze drie categorieën verschillen van degenen die wel betaalde arbeid verrichten.

- De indeling van dit boek.

Deze studie bestaat uit vijf delen.

Het eerste deel geeft een inlelding, terwijl deel vijf de afsluiting van dit boek vormt.

In deel I worden eerst de veranderde getalsverhouding van werkenden en niet werkenden én de relatie tussen niet werken en gezondheid aan de orde gesteld. Tevens leiden we in dit deel het onderzoek in met probleemstelling, hypothesen, onderzoekmethoden en onderzoekspopulaties.

In de delen II tot en met IV geven we de onderzoeksresultaten weer op basis van de vergelijking van de onderscheiden categorieën niet werkende mannen onderling ên met werkende mannen.

Deel II handelt over gezondheid en gezondheldsopvattingen. We geven de door de mannen zelf gerapporteerde gezondheid en gezondheidsopvattingen weer; tevens komt gezondheid aan de orde van mannelijke niet werkende en werkende patiënten aan de hand van rapportage van huisartsen. De consistentie van de gezondheidsmeting vormt het laatste gedeelte van dit drieluik.

Deel III handelt over twee aspecten van de leefwijze namelijk de voor de gezondheid riskante gewoonten inclusief het oordeel ower de eigen leefwijze, en de soclale participatie.

Deel IV is gewijd aan de samenhang tussen enerzljds de dur van het niet werken en anderzijds gezondheid, gezondheidsopwattingen, riskante gewoonten en participatie. Het betreft de vergelijking van kortdurig met langdurig niet werkenden, de zogenaamde transversale analyse. Tevens volgen we de niet werkenden in de tifd gedurende twee jaren: de zogenaamde longltudinale analyse.

In deel $V$ tenslotte zetten we de bevindingen nog eens op een rijtje; voorts gaan we in op de betekenis van de resultaten. 



\section{Deel I: Inleiding}

1. Inleiding Deel I

2. Werkenden en Niet Werkenden

3. Niet Werken en Gezondheid

4. Probleemstelling, Hypothesen en Operationalisatie

5. Methoden en Populaties

6. Afsluiting Deel I 



\section{Inleiding Deel I}

De hoofdstukken 2 en 3 zijn wan algemeen inleidende aard, terwijl in de hoofdstukken 4 en 5 het te betreden onderzoekspad beschreven wordt. In hoofdstuk 2 laten we ons leiden door twee vragen:

- welke subpopulaties kunnen we bif de nlet werkenden onderschelden en hoe verhouden de subpopulaties zich getalsmatig tot elkar en tot de werkenden?

- wat is het profiel wan de drie categorleën arbeidsongeschikten, werklozen en vervroegd gepenstoneerden gelet op duur van het niet werken, leeftijd, verdeling naar provincie en sociaal-economische klasse?

In hoofdstuk 3 staat het thema niet werken en gezondheid central. Op basis van literatuuronderzoek worden de drle categorieën niet werkenden vergeleken aan de hand van twee vragen:

- in hoeverre is ongezondheld oorzaak van niet werken?

- in hoeverre is ongezondheid het gevolg van niet werken?

In hoofdstuk 4 leggen we een aantal overwegingen vast die aan het onderzoek richting en inhoud geven. Deze monden uit in de probleemstelling. De te bespreken hypothesen vloelen gedeeltelijk voort ult het besprokene in hoofdstuk 3 en gedeeltelijk uit de literatuur die in dit hoofdstuk ter sprake komt. De methoden van onderzoek komen in het vijfde hoofdstuk aan bod, tezamen met een beschrijulng en verantwoording van de populaties. We ronden dit hoofdstuk af met een overzicht van de door ons in het onderzoek gebruikte statistische technieken. 


\section{Werkenden en Niet Werkenden}

\subsection{Inleiding}

Het doel van dit hoofdstuk is het waatschappelijk verschijpsel "nlet werken" getalsmat1g nader te proflleren. We stellen vast welke categorleën nlet werkenden in de Nederlandse samenleving onderscheiden kunnen worden en hoe deze zich in de loop van de tijd naar amvang ten opzlchte van elkaar en ten opzichte van werkenden ontwikkeld hebben. Omdat werklozen, arbeidsongeschlkten en vervroegd gepensloneerden in dit onderzoek centraal staan zullen we aan hen extra aandacht besteden.

In de tweede paragraaf behandelen we de veranderde verhouding tusisen werkenden en niet werkenden over de jaren 1975-1987.

In de derde paragraaf bespreken we de verdeling van de beroepsbevolking naar leeftijd en geslacht, terwijl we in de vierde paragraaf een overzicht van de aatallen niet werkenden geven. In de vijfde paragraaf gaan we, aan de hand van de beschlkbare literatuur, nader in op enkele kenmerken van de drle categorieën biet werkenden, te weten de duur van het niet werken en verdelingen naar leeftijd, provincie en ooclaal-economische klasse.

\subsection{De veranderde verhouding tussen werkenden en niet werkenden}

Ter voorkoming van misverstanden wijzen we er op dat de term "niet werkenden" in deze verhandeling verwijst naar personen die geen betaalde arbeld verrichten, dan wel buiten de officlële arbeidsmarkt verblifven. Deze omschrijving sluit aan op die van de Wetenschappe11 jke Raad voor het Regeringsbeleid (WRR), waarin onder werkenden of 
actieven die personen verstaan worden, dle daadwerkelljk aan het arbeidsproces deelnemen en daarvoor een geldelijke beloning krijgen (WRR, 1979).

"Nlet werkenden" worden ook weleens "niet actieven" genoemd. Beide termen blijken soms als belastend ervaren te worden; afhankelijk van de gevoelswarde die deze termen voor onderschelden auteurs hebben, vinden we de ene of de andere term terug. Een vrouw of man die de gehele dag actief bezlg is in huishouden en/of gezin, kan niet betiteld worden als "nliet actief", noch als "nlet werkend".

Onder niet werkenden vallen behalve werklozen, arbeldsongeschlkten en vervroegd gepensloneerden, die in deze verhandeling centraal staan, ook andere - economisch - afhankelifken, zoals jongeren in de leerplichtlge leeftijd, studerenden, huisvrouwen/huismannen en gepensioneerden. Vijf miljoen van de circa vifftien miljoen Nederlanders kowen niet in aanmerking voor betaalde arbeid omdat zij te jong (<15) of te oud $(>65)$ geacht worden. Wan de resterende tien miljoen mensem blijkt slechts de helft betaalde arbeld te verrichten. Dit betekent dat circa Eén op de drfe inwoners van Nederland werkzaam is in loondienst, of als zelfstandige.

De verhoudlng tussen werkenden en miet werkenden wordt ten dele bepaald door de demografische opbouw van de bevolking en ten dele door het gedeelte van de bevolking tussen 15 en 65 jaar dat betaalde arbeid verricht.

B1f de bevolkingsopbouw is het van belang te letten op de drie-deling: 0-14 Jaar, 15-64 jaar en 65 jaar en ouder. De eerste en derde categorle zijn in beginsel van betalde arbeld uitgesloten op basls van leeftijd en/of volledige leerplicht. Deze populatie noemen we de niet-potentiële beroepsbevolking, ondat zij niet geacht wordt betalde arbeld te verrichten. De populatie van'15 tot 65 Jaar betitelen we als potentiële beroepsbevolking, omdat de mensen die daaronder vallen in princlpe betaalde arbeld mogen verrichten. Niettemin dient opgemerkt te worden dat 1 n 1978 van de bevolking van 65 faar en ouder, toch nog $5,3 \%$ van de mannen en $1 Z$ van de vrouwen aan het arbeldsproces deelnam (1n 1960 was dit respectlevel1jk $20,7 \%$ en 2,77 - CBS, Statistibche Jaarboeken). Deze populatie zal grotendeels zijn samengesteld ult zelfstandigen en vrije beroepsbeoefenaren. Het aandeel werkende "bejaarden" blijkt duldelijk af te nemen. 
In tabel 2.1 geven we de verhouding van de potentiële en niet-potent1ele beroepsbevolking weer op drie verschillende tijdstippen.

Tabel 2. I Bevolklng van Nederland woor drie leeftijdsklassen 1n 1975, 1978 en 1983 gedifferentleerd naar potentiêle en niet potentiele beroepsbevolking $(z)$.

$1975 \quad 1978 \quad 1983$

1. potent lële beroepsbevolking
$15-65$
63,9
65,3
67,5

2. niet potent1ële beroepsbevolking waarvan:

$0-14$

36,1

34,7

32,5

$>65$

25,3

23,5

20,7

10,8

11, 2

11,8

totaal

$100 \%$

$100 \%$

$100 \%$

Bron: CBS Maandstatistieken.

U1t tabel 2.1 kunnen we opmaken dat het aandeel van de potentièle beroepsbevolking de afgelopen 20 jaar is toegenomen. We zien bij het percentage jongeren $(0-14)$ en ouderen $(>65)$ een tegengestelde ontwikkeling; het aantal jongeren neemt af, het aantal ouderen neemt toe. In een schatting voor het jaar 2000 gaat het Sociaal en Cultureel Planbureau ervan uit dat het aantal mensen dat gebruik zal maken van de AOW, op grond van demograflsche ontwlkkelingen, langzaam verder zal tijgen. Dit proces kan vooral een probleem worden wanneer in de toekomst de potentiêle beroepisbevolking afneemt, en van deze bevolking een steeds kleiner gedeelte betaalde arbeid verricht. Er wordt op gewezen dat vooral boven de 50 jaar de kans om te werken afhankellfk is van leeftijd, opleidingsntveau, al dan nlet alleenstaand $z 1 j n$ en, in mindere mate, van woonreglo. Hoog opgeleiden, samenwonenden en partner-tweeverdieners blijven langer doorwerken dan laag opgeleiden, alleenstaanden en partner-eenverdieners.

We kunnen ons eveneens afvragen welk gedeelte van de Nederlandse bevolking geen betalde arbeld verricht, zowel binnen de tatale populatie als binnen de populatie van 15 tot 65 jaar. In tabel 2.2 hebben we enkele kernc1ffers vastgelegd over de periade 1975-1985. 
Tabe1 2.2 Verhouding niet werkenden / werkenden binnen de Nederlandse populatie en binnen de leeftijdscategorie 15 tot 65 jaar van 1975 tot $1985(\times 1000)$.

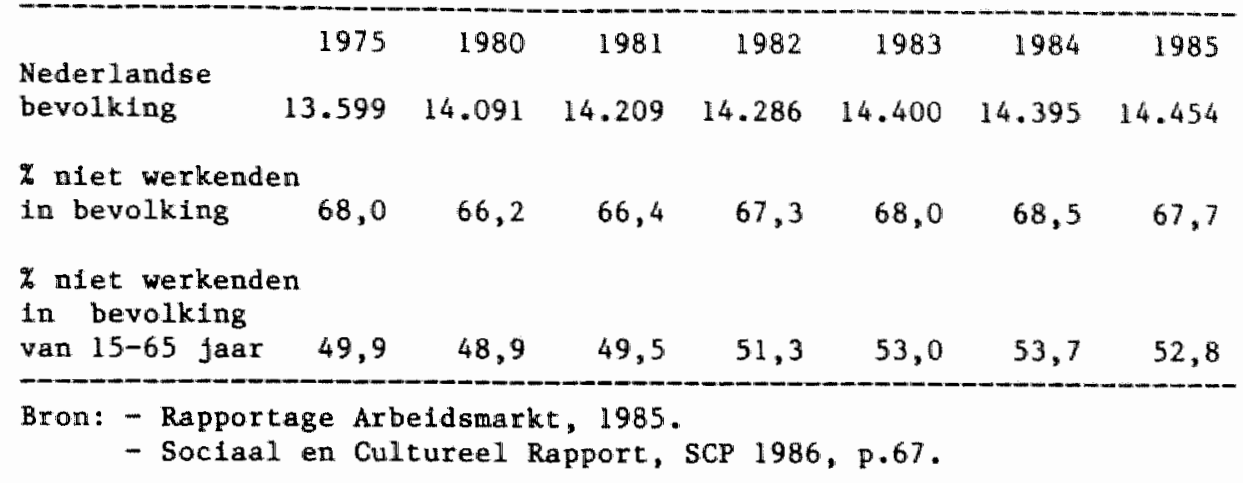

Tussen 1975 en 1980 zien we een vermindering van het percentage niet werkenden; na 1980 zien we een voortdurende toename tot 1984 . In 1985 daalt het cijfer.

Binnen de leeftijdscategorle van 15 tot 65 jaar verricht de helft van de Nederlanders betaald werk. Tot 1980 zien we eerst een afname van het percentage niet werkenden, gevolgd door een toemame tot 1984 , waarna wederom een vermindering optreedt.

Onder niet werkenden tussen 15 en 65 jaar worden de volgende categorieën verstaan: dagonderwijs-volgenden, werklozen, arbeldsongeschikten en anderen. De categorle "anderen", die het grootst in omvang is, kan onderverdeeld worden naar vervroegd gepensioneerden, huiswrouwen en personen met een part-t1me baan minder dan 20 uur per week. In 1975 vormden $z 1 j 71 \%$ van thet totale aatal niet werkenden en in 1985 "slechts" 50\%. Deze veranderde verhouding werd zeer gedeeltelljk beInvloed door een toename van het aantal dagonderwijsvolgenden (in 1975: $19 \%$ en in 1985: 23\%) en in anzienlijke mate door een toename van het aantal arbeldsongeschikten en werklozen tezamen. Het totale antal mensen dat arbeidsongeschikt, dan wel werkloos was, bedroeg in 1975436.000 en In 19851.413 .000 .

Het aantal werklozen steeg van 1975 tot 1985 van 181.000 tot 796.000 ; dat van de arbeldsongeschlkten steeg van 255.000 tot 617.000 in dezelfde perlode. Daarmee $11 \mathrm{gt}$ het probleem van het gedwongen niet werken getalsmat1g duidelijk op tafel (Rapportage Arbeidsmarkt, 1985; Soctaal en Cultureel Rapport, 1986). 
2.3 De beroepsbevolking nar gealacht en leeftifd

In 1971 behoorde $50,6 \%$ van de bevolking van 15 tot 65 jaar tot de Nederlandse beroepsbevolking. Na een anzlenlijke daling tot 48,6\% 1n 1978, steeg het percentage in 1983 tot $51,6 \%$. Deze st1jging komt geheel voor rekening van de vrowwen $(1971: 25,8 \% ; 1983: 34,9 \%)$, want bif de mamnen 18 er sprake van een voortdurende daling (1971:76\%; $1983: 68,87)$.

We kunnen ons voor mannen en vrouwen afzonderlijk afvragen welk gedeelte van de afzonderlijke leeftijdscategorieen aan het arbeldsproces deelneemt. We wijzen erop dat de faren niet geheel parallel lopen met de voorgaande; dit hangt samen met de onderscheiden bronnen die gedeeltelijk andere jaren beschrijuen.

Tabel 2.3 Deelneming aan het arbeidsproces in \% van de bevolking naar leeft1jdsklasse en geslacht in 1971, 1978, 1981, 1983, 1985.

\begin{tabular}{lrrrrr} 
& 1971 & 1978 & 1981 & 1983 & $1985^{*}$ \\
mannen & & & & & \\
$15-24$ & 65 & 50 & 52 & 51 & 49 \\
$25-49$ & 97 & 95 & 95 & 95 & 96 \\
$50-64$ & 85 & 77 & 70 & 68 & 74 \\
$65+$ & 11 & 5 & 4 & 4 & 4 \\
vrouwen & & & & & \\
$15-24$ & 53 & 48 & 51 & 50 & 49 \\
$25-49$ & 24 & 34 & 42 & 47 & 28 \\
$50-64$ & 17 & 18 & 18 & 20 & 1 \\
$\quad 65+$ & 2 & 1 & 1 & 1 & \\
\hline
\end{tabular}

Bron: CBS Statistical Yearbooks.

* betekent: schatting

Tabel 2.3 lat een anzienlijke varlatile zlen van het percentage werkenden over belde geslachten en over verschillende leeftijdsklassen. Tussen 1971 en 1985 blifken mannen tussen 25 en 49 jaar de meest stablele categorle, varlërend van 95 tot $97 \%$. Opvallend is de st1jging van het percentage vrouwen tussen 25 en 64 jaar, dat in de periade 1971 en 1985 aan het arbeldsproces deelneemt. Ook de st1jging van het percentage mannen van 50 tot 64 Jaar tussen 1983 en 1985 valt op. 
Uit een ander overzlcht van het CBS over 1982 bll jkt dat winder dan de helft van de mannen tussen 60 en 64 jaar betaalde arbeld verricht (40\%). In de leeftijdscategorle 55-59 jaar was dit nog $73 \%$. Bij de vrouwen waren de cijfers respectlevelijk 7\% en $21 \%$. Dit bleek in 1981 ook voor alle landen van de Europese Gemeenschap te gelden; voor de gehele EG bleek het percentage werkende mannen tussen 60 en 65 jaar $47,5 \%$ te $z 1 j n$. De reden van stoppen met werken in Nederland onder de kostwinners van 55 tot 65 jaar blijkt overwegend arbeldsongeschiktheid te zijn. Van de mannen van 55-59 jaar die niet meer werken, $1566 \%$ vanult het arbeldsproces naar de arbeldsongeschiktheidswet gestapt en $11 \%$ naar de werkloosheldswet. Voor de categorle mannen van 60-64 jaar waren de redenen achtereenvolgens WAO/AAW (42\%), VUT-regelingen (30\%) en werkloosheld $(6 \%)$. Over de vrouwen van 55-64 jaar zijn minder betrouwbare uitspraken voorhanden. Volgens het CBS hebben zij vaker dan mannen zelf besloten met werken te stoppen; daarnaast hebben zij minder vaak van de WAO/AAW gebruik gemaakt (CBS, leefsituatie, 1982; lb, kerncijfers).

2.4 Werklozen, arbeidsongeschikten en vervroegd gepensioneerden vanaf 1971

Wij richten ons nu op de voor ons relevante categorieën niet werkenden, vanuit de vraag, welke veranderingen in aantallen arbeidsongeschikten en werklozen sedert $1971 \mathrm{zijn}$ opgetreden. Daar over vervroegd gepensioneerden gegevens ontbreken, worden zij in tabel 2.4 bulten beschouwing gelaten. We komen hlerop nog afzonderlijk terug. In de tabel maken we geen onderscheid nar geslacht omdat tot 1980 hierom trent geen betrouwbare cljfers beschikbaar zijn.

Sinds 1971 is er sprake van een continue stijging van het aantal werklozen en arbeldsongeschikten. Tussen 1977 en 1979 zlen we dat de stljging onderbroken wordt door eem lichte dallng van het aantal werklozen. Na 1980 zien we een abrupte stijging; 1n 1981 werd voor beide categorieën gezamenlijk het magische getal van 1 miljoen overschreden. De toename van het aantal werklozen is anzienlijk sterker dan de toename van het aantal arbeidsongeschikten. Het aantal arbeldsongeschikten bl1jkt echter nog steeds het aantal werklozen te overstijgen. 


\begin{tabular}{|c|c|c|c|}
\hline & werklozen & arbeldsongeschikten & totaal \\
\hline 1971 & 68 & 255 & 323 \\
\hline 1972 & 111 & 281 & 392 \\
\hline 1973 & 109 & 309 & 418 \\
\hline 1974 & 132 & 342 & 474 \\
\hline 1975 & 198 & 381 & 579 \\
\hline 1976 & 212 & 506 & 718 \\
\hline 1977 & 208 & 557 & 765 \\
\hline 1978 & 208 & 608 & 816 \\
\hline 1979 & 221 & 643 & 864 \\
\hline 1980 & 238 & 683 & 921 \\
\hline 1981 & 359 & 706 & 1065 \\
\hline 1982 & 510 & 728 & 1238 \\
\hline 1983 & 622 & 741 & 1363 \\
\hline
\end{tabular}

1) U1tgezonderd degenen die in WSW-verband werkzaam zijn (van $1971 \mathrm{t} / \mathrm{m}$ 1982).

Bron: - Ministerle van Sociale Zaken en Werkgelegenheld, 1984, p.97. - Soclaal Cultureel Planbureau, 1986, p.11.

Andere bronnen geven weer entgszins andere cijfers, zonder dat bij voorbaat duldelijk is wat de redenen $z i j n$ van de onderlinge verschillen (vergel1jk: Rapportage Arbeidsmarkt, 1985, p.21; Soclaal en Cultureel Planbureau, $1986, p .67)$. Zo vinden we in de latstgenoemde 1iteratuur in 1983765.000 werklozen in plaats van de in tabel 2.5 vermelde 622.000. De verschillen in cijfers zija terug te voeren op verachillen in rekenmethoden en het hanteren van verschillende definities van werkloosheld (zte onder meer Spruit, 1984). Zo is bekend dat sedert $\$ 985$ werklozen van 57,5 jaar en ouder nlet meer als zodanig worden benoemd. Anno 1937 worden personen als werkloos beschouwd wanneer zlj geen betabld werk verrichten, onmiddeliljk beschikbaar zijn voor betaild werk, en daarnaar actlef zoeken. Tot zover stemt de definitie die officleel in Nederland gehanteerd wordt overeen met die van de ILO (International Labour Organisation). De Nederlandse definitie van de gereglstreerde werkloosheld verschllt op twee punten:

1 ze beperkt zich tot die werklozen die ingeschreven staan bij een arbeldsbureau;

2 ze omvat alleen die mensen die minstens 20 ur per week betaide arbeld willen verrichten.

Er bestaat $n 6 g$ een deel werkloosheld, namelifk die van de verborgen 
werklozen. Het C.B.S. echter tracht met behulp van de arbeidskrathtentelling de totale werkloosheld te meten volgens de ILO-definitie. In deze arbeldskrachtentelling (AKT) wordt onder werklozen verstaan:

- personen die een werkloosheidsultkering ontvangen en/of actief werk zoeken via de G.A.B.'s of uitzendbureaus, door te sollictteren op advertenties, door elgen nawraag bij bedrijven en dergelijke, en tevens beschikbaar $z i j n$ om arbeld te aapwarden;

- personen die wel een werkkring aanvaard hebben, maar met dle werkzaamheden nog niet begonnen zijn.

De AKT leidt enerzljds tot lagere werkloosheldscljfers door deze te ontdoen van bestandsvervulling. Anderzijds vergroot zij de werkloosheld door niet geregistreerde werklozen eraan toe te voegen.

Ten gevolge van verschillen in belde definities komen het Ministerie van Sociale Zaken en het C.B.S. tot getallen, die tiendulzenden uit elkaar liggen (Luttik, 1987).

Het voordeel van de CBS-reglstratie boven die van het mintsterie is dat deze beter aansluit op de internationale matstaven.

Het blijkt moeilijk inzicht te krijgen in de omvang van de verborgen werkloosheld, vooral van de onder vrouwen. Het antal werd in 1983 tussen 100.000 tot 280.000 personen geschat. Het Sociaal cultureel Planbureau (SCP) brengt de interessante opmerking naar voren dat, naarmate de conjunctuur aantrekt, een groter deel van de verborgen werklozen versneld maar de arbeldsmarkt stroomt en daar een extra onverwacht aanbod vormt. Dit aanbod zou vooral huiswrouwen betreffen, maar ook scholleren * suderenden en vervroegd gepensioneerden (SCP 1986). Vanult dit gezichtspunt zou een toename van het aantal werklozen betekenen dat in de samenleving een verbetering van de economle verwacht wordt*

In onderschelden bronnen over aantallen arbeldsongeschikten vinden we eveneens verschillende getallen. Deze discrepanties vallen temeer op omdat de betrouwbarbeid van de ciffers lnzake arbeldsongeschiktheid hoger wordt geschat dan die over werkloosheld. Zonder grondig onderzoek kan de lezer over de oorzaak van deze verschillen slechts gissingen doen. Voor ultvoerige Informatie hierover verwijzen we naar Groothoff (1986). Verschillen hangen onder andere samen met het al dan niet 
opnemen van arbeldsongeschikten die werken, die wan jongs af aan niet 10 stmat zijn tot betalde arbeld, die slechts gedeeltelijk arbeldsongeschikt zijn $(16,3 \%$ in 1987) of die in het bultenland wonen $6 \mathrm{n}$ van specifieke categorlectn. Zo is bekend dat het GMD in de door haar verstrekte overzichten drie deelcategorleën niet opneemt: arbeidsongeschlktel die onder het ABP Invaliditelts Pensioen vallen, arbeidsongeschlkte miltairen en arbeidsongeschikten van de Nederlandse Spoorwegen.

We hebben al eerder gesteld dat van het aantal vuT-ers als vervroegd gepensioneerden alleen schattingen gegeven kunnen worden. De regelingen inzake vervroegde uittreding zijn verbrokkeld, hetgeen nauwkeurige telling bemoellijkt, zo niet onmogelijk maakt (Ministerie Soctale Zaken, 1981; SCP 1986). De eerste experimentele WUT-regelingen werden $1 \mathrm{n}$ december 1976 in het onderwijs ingevoerd en in 1977 in de bouwnljuerheld, kort daarop gevolgd door de metaalindustrle, Hoogovens en de havenbedrijven. Sedert 1980 zijn de vuT-regelingen regulier geworden bij 93 bedriffstakken en 98 grote ondernemingen. Een van de kenmerken van de vuT-regeling is dat deze vrijw111.g $1 \mathrm{~s}$, hoewel hiervan steeds minder sprake $11 j k t$ te zijn (Ministerie Sociale Zaken, 1981). Tijdens het experimentele stadium bedroeg het aantal VuT-ers 277 ; elnd 1980 werd het aantal VUT-uitkeringen op 20.000 geschat. In 1982 zou het antal VUT-ultkeringsgerechtigden circa 35.600 bedragen, in 198364.000 en in 198489.200 (Minsiterie Sociale Zaken, 1981; SCP, 1986; Rapport Arbeldemarkt, 1985).

Het blifkt dus dat er een anzlenlijke toename van het antal vervroegd gepenstoneerden blanen het reguliere kader 15 , hoewel het aantal relatief gering blifft in relatie tot werklozen en arbeldsongeschikten. We mogen echter annemen dat genoemde aantallen een aanzien11jke onderschatting Inhouden. Onder vervroegd gepensioneerden vallen Immers ook degenen die op basis van nlet regullere vuT-regelingen van t1jdelljke aard met werken gestopt z1jn. Zo had de PTT elnd 1980 een t1jdelljke afzonderlijke regeling ontworpen, genaamd Experimenteel Flexibel Uttreden (flexult-regeling), die tot 1 januari 1983 in stand zou blifven. Zonder deze regeling kon men bij de PTT vanaf 63 jaar vervroegd uittreden; voor de flexult-regeling kon men vanaf het zes- 
tigste jaar in aanmerking komen. De flexult-ers konden later niet meer overstappen naar de VUT-regeling. De flexult-regeling had als bijzonder kenmerk dat werknemers ook de gelegenheld kregen gedeeltell jk ult te treden, alsmede gedeeltelijk aan te blijven na het 65 e levensjaar (Hoofddirectie PTT, 1980).

Het aantal van 89.200 is om nog een tweede reden warschijnlijk een onderschatting. De reeds lang bestaande vorm van beroepsgebonden vroege pensionering (onder andere ambulancepersoneel, militairen) betreft immers ook een groat aantal mensen. Wanneer we alle voor hun 65 e gepensioneerden bij de berekening betrekken, bedraagt het aantal (ver)vroeg(d) gepensloneerden In 1985 minstens 158.800 personen (CBS, arbeldskrachtentelling, 1985). Strikt genomen betreft dit gedeeltelijk vervroegd gepenstoneerden in de betekenis van VUT-ers en gedeeltelijk vroeg gepensioneerden.

2.5 Enkele kenmerken van niet werkenden

\subsubsection{Inleiding}

In deze paragraaf zullen we arbeldsongeschlkten, werklozen en vervroegd gepensioneerden beschrijven in termen van de duur van het nlet werken, leeftijd, en verdeling naar provincie en sociaal-economische klasse.

We bespraken achtereenvolgens de dur van het nlet werken, de relatie tussen 1 eeftijd en niet werken, de relatle tussen leeftijd en duur van het niet werken om tot slot stil te staan bil de verdeling van niet werkenden over de provincles en sociaal economische klassen. Per onderwerp geven we achtereenvolgens inforwatie over werklozen en arbeidsongeschikten. Vervroegd gepensioneerden komen pas in paragraaf 2.5.5 aan de orde, omdat de overige gegevens ontbreken. 


\subsubsection{Duur nfet werken}

\section{a Werklozen}

In de wolgende tobel wordt een overzlcht gegeven van de duur van de werkloosheld.

Tabel 2.5 Gereglotreerde werkloosheid naar gereallseerde duur van inBchrijuling 1982 - 1985 (jaargemiddelden) (\%)

\begin{tabular}{rrrrr}
\hline duur In jaren & 1982 & 1983 & 1984 & 1985 \\
$<1$ & 69 & 56 & 47 & 46 \\
$1-2$ & 21 & 26 & 26 & 21 \\
$2-3$ & 6 & 11 & 15 & 15 \\
$3-4$ & 2 & 4 & 7 & 10 \\
$\geq 4$ & 2 & 3 & 4 & 8 \\
total & $100 \%$ & $100 \%$ & $100 \%$ & $100 \%$ \\
\hline
\end{tabular}

Bron: Soclaal Cultureel Rapport, 1986, p.68

Uit tobel 2.5 blijkt dat in de loop van de t1jd een toenemend aantal werklozen langere tijd zonder werk ts. Was in $198269 \%$ één jaar of korter werkloos, in 1985 blljkt dit nog maar het geval te zijn bij minder dan de helft $(46 \%)$. Ter aanvulling wijzen we erop dat in het begin der zeventiger jaren het antal langdurig werklozen "slechts" $10 \%$ was. We zlen tevens dat de twee klassen met de langdurlgste werkloosheld tezamen in drle jaar van $4 \%$ naar $18 \%$ gestegen $z i j n$.

U1t een andere bron kunnen we opmaken dat in $198453 \%$ van de mannen en $49 \%$ van de vrouwen Een jaar of langer zonder werk waren (Rapportage Arbeldsmarkt 1986, p.59).

In het begin der zeventiger jaren was de kans van werklozen op nieuw werk gering; met de toenemende werkloosheld is deze mog geringer geworden (SCP, p.311). Het SCP heeft op basis van door het Ministerle van Soclale Zaken en Werkgelegenheld geleverde gegevens over 1981 tot 1985 berekend, dat natrmate een persoon in jaren langer werkloos is, de kans groter wordt dat deze persoon nog een jaar langer werkloos blifft ("werklozen worden werklozer", advertentie G.A.B.). Na 1985 is er een lets grotere toestroom ontstaan van, vooral kortdurig, werklozen richting arbeldsmarkt (SCP, 1986). 
b Arbeldsongeschilten

Arbeldsongeschiktheld blifkt veelal voor degenen de het betreft ten blifvende aangelegenheld te z1jn: Een jaar na intrede in de MAOAM bl1jkt $11 \%$ het werk hervat te hebben, in het tweede jaar hervat nog eens $4 \%$ het werk. Tussen het derde en tlende jaar st1jgt het totale percentage hervatters met nog mar $6 \%$, zodat er tlen jaar na intrede In een arbeldsongeschiktheldswet slechts $21 \%$ weer met betaalde arbeld gestart is (Buys, 1984). Uittreding blijkt voornamelijk te geschieden op grond van penstonering en overlijden (75\%). Sedert de invoering van de WAO (1968) als verplichte werknemersregeling Én de AAW als volksverzekering (1976) is het aantal toekenningen per jaar groter dan het aantal beëlndiglngen. Wel constateren we een afname van het aantal toekenningen.

Flguur 1 Ontwikkeling arbeidsongeschikten, toekenningen en beëlndigen voor loontrekkenden (x1000).

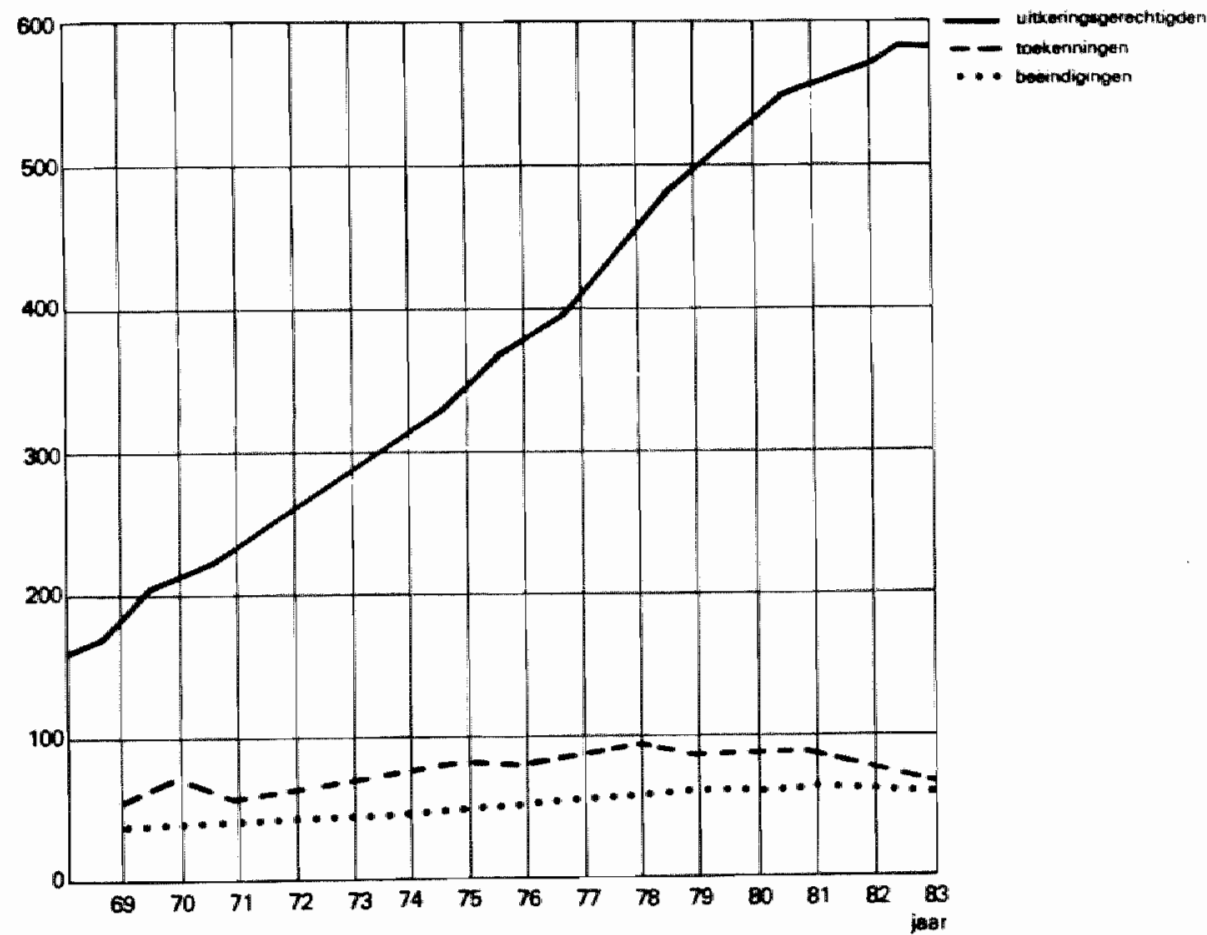

Bron: D. Kagenaar et al., Huisarts en arbeldsongeschikthe1d, 1985, P.15. 
In figur 1 is de ontwikkeling van het antal ultkeringsgerechtigden bedert 1969 gevl suallseerd. Er blijkt sprake van een sterke, gelljkmat1ge grael. De let snellere st1jglng vanaf 1976 hangt samen met de Invoerlng wan de AN In oktober 1976. Vanaf het midden van 1980 zien we een 1 ichte breuk in de $11 \mathrm{jn}$, die samenhangt met een geleidelijke dallng van het antal toekenningen. De groel van begin 1982 wordt halverwege het jaar gevolgd door een stabilisering. Het aantal beelndiglagen st1jgt wanaf 1969 langzaam.

In tabe1 2.6 wrdt de ontwikkellag van het aantal arbeidsongeschikten over de jaren 1981 tot 1985 meer ta detall weergegeven.

Tabel 2.6 Ontwikkelling van de aantallen arbeldsongeschikten WAO/AAW $(\mathrm{x} 1000)$.

$\begin{array}{lrrrrr} & 1981 & 1982 & 1983 & 1984 & 1985 \\ \text { Aantal op 1 januar1 } & 629 & 648 & 662 & 673 & 685 \\ \text { Toekenningen } & 76 & 71 & 66 & 64 & 64 \\ \text { Beëindigingen } & 57 & 57 & 55 & 52 & 59 \\ \text { waarvan door } & 7 & 7 & 9 & 9 & 8 \\ \text { - overlijden } & 29 & 28 & 27 & 25 & 33 \\ \text { - 65-plus } & 21 & 21 & 19 & 18 & 17 \\ \text { - herstel } & 648 & 662 & 673 & 685 & 690 \\ \text { Aantal op 31 december } & (11,8) & (11,7) & (11,6) & (11,6) & (11,6) \\ \text { (1n \% verzekerden) } & & & & & \end{array}$

Bron: WAO/AAW kerncijfers.

De in grafiek 1 weergegeven veranderde verhouding tussen toekenningen en beedndiglingen tussen 1981 en 1983 zien we in tabel 2.6 terug. We zien tevens dat het antal toekenningen in 1984 en 1985 stabiliseert op 64.000, terwij1 het aantal beexindigingen na een daling in 19.84, in 1985 wer stijgt tot 59.000 .

In tabel 2.6 valt tevens op dat de arbeldsongeschiktheldsuitkerlngen in volgorde wan belangrijkheid efndigen door pensionering, herstel en overlijden. Het aantal overledenen varleert tussen 7000 en 9000 arbeldsongeschikten per jaar. Dit alles impliceert voor het merendeel der arbeldsongeschikten: "eens arbeldsongeschikt, altijd arbeldsongeschikt". 


\subsubsection{Leeftijd en nlet werken}

a. Werklozen

In de volgende tabel gaan we in op de vraag hoe de spreiding van de werkloosheld is over de onderschelden leeftijdscategorieën, gedifferentleerd naar mannen en vrouwen. De gereglitreerde werkloosheid wordt berekend in procenten van de afhankelijke beroepsbevolking.

Tabel 2.7 Gereglstreerde werkloosheld naar geslacht en leeftijd (jaargemiddelden) (\%).

\begin{tabular}{|c|c|c|c|c|c|c|c|c|}
\hline \multirow[b]{2}{*}{ 1eeftijd } & \multicolumn{2}{|c|}{$\begin{array}{l}\text { Aandeel } \\
1982\end{array}$} & \multicolumn{2}{|c|}{$\begin{array}{l}\text { af hankel } 1 \mathrm{jke} \\
1983\end{array}$} & \multicolumn{4}{|c|}{$\begin{array}{l}\text { beroepsbevolking } \\
1984\end{array}$} \\
\hline & $\mathbf{m}$ & $v$ & m & v & m & v & $\mathrm{m}$ & $\mathbf{v}$ \\
\hline $15-24$ & 28 & 26 & 33 & 31 & 32 & 32 & 30 & 31 \\
\hline $25-39$ & 12 & 12 & 14 & 14 & 15 & 15 & 14 & 15 \\
\hline $40-49$ & 9 & 12 & 11 & 13 & 12 & 13 & 11 & 13 \\
\hline $50-54$ & 8 & 10 & 10 & 11 & 11 & 12 & 11 & 12 \\
\hline $55-59$ & 9 & 10 & 12 & 11 & 10 & 10 & 7 & 8 \\
\hline $60-64$ & 23 & 21 & 29 & 23 & 23 & 16 & 4 & 3 \\
\hline totaal & 13 & 16 & 16 & 18 & 16 & 19 & 15 & 18 \\
\hline
\end{tabular}

* maming

Bron: Rapportage Arbeidsmarkt, 1985, p.5.4.

Opvallend in tabel 2.7 is de hoge werkloosheid van zowel mannen als vrouwen onder de jongeren. Naarmate de leeftijd toeneemt, zien we een daling van het aandeel van de werkloosheld tot de categorie 60-64 jartgen. Bif deze categorie stijgt het andeel, met witzondering van 1985. Dit laatste heeft te maken met de matregel van de overheld om $57 \frac{1}{2}$ jarigen en ouder te ontheffen van de plicht werk te zoeken.

Het percentage onder de vrouwen blijkt steeds hoger te 11 ggen dan onder de mannen; het onderlinge versch1l verandert in de loop der jaren nauwelijks.

Voorts valt op dat tussen 1982 en 1984 binnen alle leeftifdscategorleën sprake is van een toename, en tussen 1984 en 1985 in de leeftijascategorie 15-55 jaar van een afname, van het percentage werklozen. 


\section{b Arbe1dsongeschikten}

In de volgende tabel geven we de verdelling weer van arbeldsongeschlkten over versch1llende leeft1jdggroepen tussen 1984 en 1986.

Tabe1 2.8 Ontwikkellng van de antallen arbeldsongeschikten WAO/AAW naar leeftifd en geslacht per I januar1 1984, 1985, 1986 $(\boldsymbol{x})$.

\begin{tabular}{|c|c|c|c|c|c|c|}
\hline & \multicolumn{2}{|c|}{1984} & \multicolumn{2}{|c|}{1985} & \multicolumn{2}{|c|}{$1986 *$} \\
\hline & m & $v$ & m & $v$ & 田 & $v$ \\
\hline $\begin{array}{l}15-24 \\
25-34 \\
35-44 \\
45-54 \\
55-65\end{array}$ & $\begin{array}{r}3 \\
10 \\
17 \\
26 \\
44\end{array}$ & $\begin{array}{r}7 \\
16 \\
17 \\
24 \\
36\end{array}$ & $\begin{array}{r}3 \\
10 \\
17 \\
28 \\
43\end{array}$ & $\begin{array}{l}6 \\
15 \\
18 \\
25 \\
36\end{array}$ & $\begin{array}{r}3 \\
9 \\
17 \\
28 \\
43\end{array}$ & $\begin{array}{r}6 \\
15 \\
18 \\
25 \\
36\end{array}$ \\
\hline Totaal & & & & & & \\
\hline
\end{tabular}

* schattingen

Bron: AAW/WAO kerncijfers, 1986

U1t tabel 2.8 blijkt dat, zoals te verwachten was op basis van het voorgaande, het merendeel der arbeidsongeschikten 45 jaar of ouder is. De getallen over de achtereenvolgende Jaren zijn stabiel. Ook dit hoeft ons niet te verbazen, gelet op het relatief kleine aantal toekenningen en beëlndigingen per jaar.

Tot slot valt op dat bij vrouwen de jongeren sterker vertegenwoordigd. zijn dan bij mannea.

\section{5 .4 Leef $1 \mathrm{jd}$ en duur niet werken}

\section{a Werklozen}

In tabe1 1.9 beschrijven we de samenhang tussen duur van Inschrijving. enerz1jds en leeft 1 jdscategorieën anderzijds.

Uit de eerste kolomen van de drie leeftijdscategorleën blijkt dat het aandeel kortdurig werklozen in de tijd afneemt. Bij de langdurig werklozen (tweede kolommen) zien we eveneens een daling, hoewel bif de jongeren een st1jging wargenomen wordt. Opvallend is dat het aandeel. zeer langdurıg werklozen (derde kolommen) tussen 1982 en 1985 sterk toeneemt. 
Uit de tabel kunnen we eveneens aflezen dat namate de leeftujd stijgt, de werkloosheid langduriger wordt.

Tabel 2.9 Geregistreerde werkloosheld naar leeftijd en gerealiseerde dur van inschrijuling (jaargemiddelden) ( $x$ ).

$$
<23 \text { jaar } 23 \text { - } 50 \text { jaar }>50 \text { jaar }
$$

jaar $\leq 6$ mind $6-12>12$ mand $\leq 6$ mind $6-12>12$ mnd $\leq 6$ mind $6-12>12$ mnd

$\begin{array}{llllllllll}1982 \text { a) } & 55 & 24 & 21 & 41 & 24 & 35 & 30 & 21 & 49 \\ 1983 & 45 & 25 & 30 & 31 & 21 & 48 & 20 & 18 & 62 \\ 1984 & 41 & 23 & 36 & 26 & 17 & 58 & 14 & 14 & 73 \\ 1984 & 36 & 28 & 36 & 26 & 18 & 56 & 15 & 15 & 71 \\ 1985 & 38 & 25 & 37 & 26 & 16 & 58 & 18 & 12 & 70\end{array}$

a) per leeft1jdscategorie $1 \mathrm{~s}$ elke rij $100 \%$ Bron: Rapportage Arbeldsmarkt, 1985, p.54.

b Arbeidsongeschikten

In figuur 2 geven we een overzicht van de bestandsopbouw van arbeldsongeschikten naar leeftijd bij aanvang van de uitkering.

Figuur 2 Bestandsopbouw WAO in 1983 naar leeftijd bij aanvang ultkering (mannen en vrouwen).

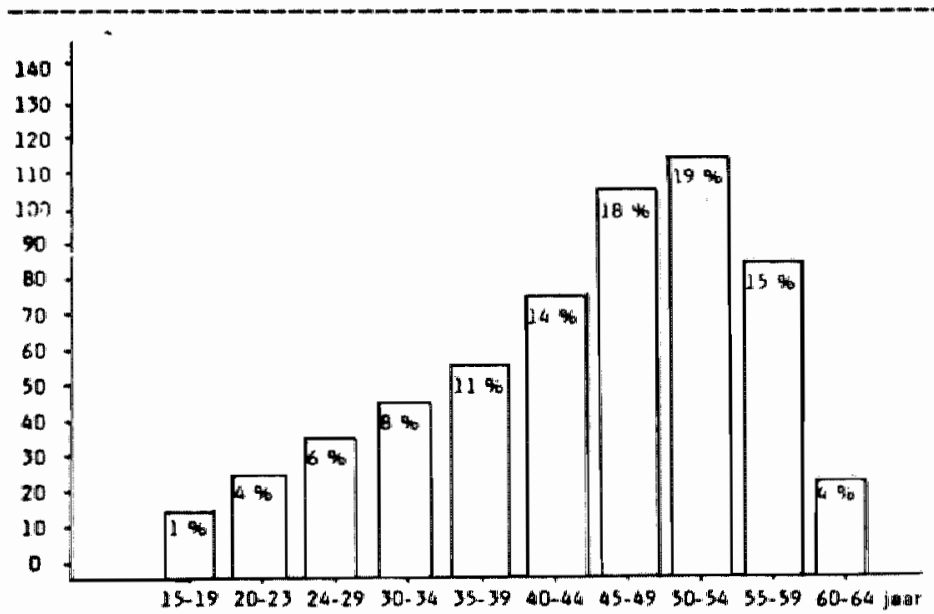

Bron: Begroting Soclale Zaken, 1984, bijlage X, p.68. 
Dit flgutz 2 blijkt dat tot de 54-jarlge leeftijd de instroom gestadig met de leeftijd toeneent, na de leeftljd van 55 jaar is de instroom aanzlenlifk lager. We mogen amnemen dat het totale aantal arbeldsongeschlkten toeneemt narmate de leeftijd vordert, gelet op de geringe herstelkans vooral op oudere leeft1jd. Groothoff (1986) heeft de heratelkans van alle arbeldsongeschikten over de onderscheiden leeft1jdsgroepen als volgt gespecificeerd: tussen de 20 en 24 jaar 1 s deze 70\%. tussen de 40 en 44 jaar $25 \%$ en tussen de 60 en 64 jaar 0\%. Deze berekening heeft betrekklng op de periode 1969-1979.

\subsubsection{Verdeling niet werkenden naar provincie en sociaal-economische klasse}

\section{a Werklozen}

De werkloosheld is alet evenredig verdeeld over de Nederlandse provincies. In elke prowincle heerst onder vrouwen een grotere werkloosheld dan onder mannen. Voorts blijkt in alle provincles een toename tussen 1980 en 1982 .

Utrecht blijkt er in het algemeen het gunstigst af te komen. Uit andere CBS-bronnen komt naar voren dat tot 1978 de positie van NoordBrabant en Limburg verslechterde ten opzichte van de andere provincies. Na 1978 verbeterde deze. Deze tendens zette $z 1 \mathrm{ch}$ voort tot 1985 (CBS, Soctale Maandstatistieken, 1983).

In tabel 2.10 laten we zien op welke wijze werklozen over vier saciaal-economlache klassen verdeeld zijn. Door de verdelling van de werkenden ernaat te platsen, kunnen we de werklozen proflleren. We zlen duldelijk dat onder werklozen vergeleken met werkenden de lagere soclaal-economlsche klassen oververtegenwoordigd zijn. 
Tabel 2.10 Verdeling werkenden en werklozen naar hoogst behalde onderwijsdiploma, gedifferentleerd naar mannen en vrouwen in $1985 \%)$.

\begin{tabular}{|c|c|c|c|c|}
\hline & \multicolumn{2}{|c|}{ werkenden } & \multicolumn{2}{|c|}{ werklozen } \\
\hline & m & v & $\mathrm{m}$ & w \\
\hline lagere school & 14 & 13 & 36 & 28 \\
\hline LBO/MAVO & 28 & 31 & 34 & 35 \\
\hline MBO/HAVO/VWO & 40 & 38 & 22 & 26 \\
\hline HBO/UnIversiteit & 18 & 18 & 8 & 11 \\
\hline Totaal & \multicolumn{2}{|c|}{$100 \%$} & \multicolumn{2}{|c|}{$100 \%$} \\
\hline$N(x 1000)$ & 3358 & 1700 & 396 & 288 \\
\hline non-response in $\%$ & 1.5 & 1.7 & 2.2 & 1.2 \\
\hline
\end{tabular}

Bron: C.B.S., Arbeidskrachtentel11ng, 1985

\section{b Arbeidsongeschikten}

Arbeidsongeschiktheld is evenals werkloosheid ongeligk verdeeld over de provincles. In 1985 had Limburg met $9,5 \%$ de hoogste score, terwifl Zeeland met $5,4 \%$ het laagst scoorde. Letten we op het geslacht, dan blijkt Limburg voor de mannen eveneens het hoogst te scoren $(14,4 \%)$ en Flevoland $(8,4 \%)$ het laagat. Bif de vrouwen zijn dit respectlevelifk Noord Holland $(5,2 \%)$ en Zeeland $(2,8 \%)$.

Analoog aan de weergave van werklozen geven we in tabel 2.11 een vergelijking van arbeldsongeschikten naar sociaal-economische klasse, op basis van het hoogst behalde onderwijsdiploma.

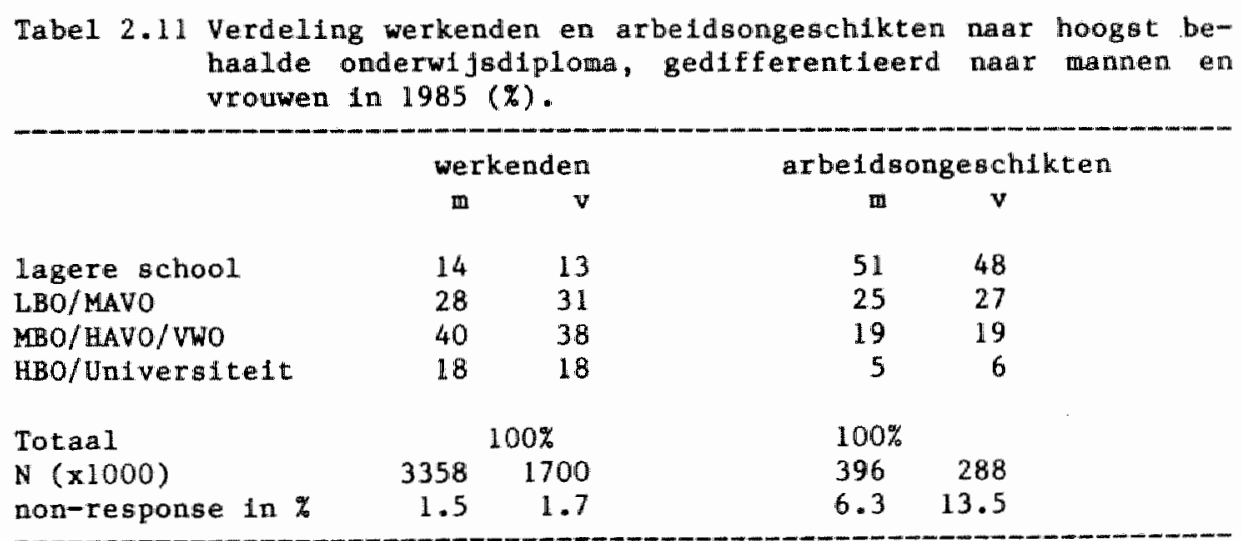

Bron: C.B.S., Arbeldskrachtentelling, 1985 
Ook onder de arbeldsongeachlkten blitken de lagere soclaal-economische klassen oververtegenwoordigd te zijn, zelfs in anzlenlijk sterkere mate dan onder de werklozen.

\section{c. Vervroegd gepensioneerden}

Zoals al eerder gestell zijn weinig gegevens beschikbaar over vervroegd gepensloneerden. Landel1jke registratie ontbreekt. Naast de Informatie dife we eerder vermeldden, heeft het CBS ons op verzoek gegevens verstrekt over de verdeling over de provincles en over de sociaal-economische klassen.

Het blijkt dat de spreiding over de provincies van vervroegd gepenclomeerden - zowel mannen als wrouwen - in werhouding tot de bevolking tussen 50 en 65 jaar b1j mannen varleert van $9 \%$ tot $14 \%$ en bij vrouwen van $2 \%$ tot $7 \%$. Onder mannen geven Zeeland en Zuid Holland met $14 \%$ en 13\% de hoogste percentages en LImburg met 9\% het laagste cljfer te zlen. Onder vrouwen scoort Zuld Holland met $7 \%$ het hoogst en Limburg met $2 \%$ het laagst.

In de volgende en laatste tabel geven we de verdeling over soclaaleconomische klassen weer van wervroegd gepensioneerden in vergelijking met werkenden.

\begin{tabular}{|c|c|c|c|c|c|c|c|}
\hline \multirow[t]{3}{*}{ Tabe1 2.12} & \multicolumn{4}{|c|}{$\begin{array}{l}\text { Verdeling werkenden en vervroegd } \\
\text { hoogst behaalde onderwijsdiploma, } \\
\text { mannen en vrouwen in } 1985(\%) \text {. }\end{array}$} & \multicolumn{2}{|c|}{$\begin{array}{l}\text { gepensloneerden } \\
\text { gedifferentieerd }\end{array}$} & $\begin{array}{l}\text { naar } \\
\text { naar }\end{array}$ \\
\hline & & \multicolumn{2}{|c|}{ werkenden } & \multicolumn{3}{|c|}{$\begin{array}{c}\text { vervroegd } \\
\text { gepensioneerden }\end{array}$} & \\
\hline & & $\mathbf{m}$ & $\mathbf{v}$ & & m & $\mathbf{v}$ & \\
\hline \multicolumn{2}{|c|}{ Lagere school } & 14 & 13 & & 22 & 46 & \\
\hline \multicolumn{2}{|c|}{ LBO/MAVO } & 28 & 31 & & 21 & 25 & \\
\hline \multicolumn{2}{|c|}{ MBO/HAVO/VWO } & 40 & 38 & & 33 & 20 & \\
\hline \multicolumn{2}{|c|}{ HBO/Untversiteit } & 18 & 18 & & 14 & 9 & \\
\hline \multirow{2}{*}{\multicolumn{2}{|c|}{$\begin{array}{l}\text { Totaal } \\
\mathrm{N}(\times 1000)\end{array}$}} & \multicolumn{2}{|c|}{$100 \%$} & \multicolumn{3}{|c|}{$100 \%$} & \\
\hline & & 3358 & 1700 & & 12 & 47 & \\
\hline \multicolumn{2}{|c|}{ non-response in $\%$} & 1.5 & 1.7 & & & 27.2 & \\
\hline
\end{tabular}

Bron: C.B.S., Arbeldskrachtentelling, 1985 
Bezien we tabel 2.12 , dan valt op dat mannelijke vervroegd gepensioneerden weinig afwijken van werkende mannen en vrouwelijke vervroegd gepensloneerden in aanzlenlifke mate verschillen van werkende wrowwen. Omdat er geen gegevens voorhanden $z 1 \mathrm{jn}$ over vervroegd gepensioneerden, gedifferentieerd naar vroeg gepensioneerden en vervroegde uittreders, is het niet mogelijk vast te stellen of deze laatste categorie inderdaad in anzienlijke mate mensen uit hogere sociaal-economische klassen omvat. In de "grijze literatuur", voornamelijk bedriffisapporten, komt dit uitdrukkel1 jk naar voren (o.a. Hoofddirectie PTr, 1980).

\subsection{Samenvatting}

Een op de drie inwoners van Nederland is in loondienst of als zelfstandige werkzaam. Binnen de leeftijdscategorle van 15 tot 65 jaar 18 de helft van de bevolking in loondienst of zelfstandig werkzaam. De categorieën niet werkenden tussen de 15 en 65 jaar worden in afnemende volgorde van grootte gevormd door huisvrouwen, dagonderwijs-volgenden, werklozen, arbeldsongeschikten en vervroegd gepensloneerden. In de loop der jaren zijn de laatste drle categorleën steeds groter geworden.

Van de laatste drie categorieën hebben de vervroegd gepensioneerden de langste staat van (arbelds)dienst achter de rug, terwijl zij in beginsel het betaalde werk nlet meer hervatten.

De leeftljd warop werkenden arbeldsongeschikt worden, varleert van 15 tot 65 jaar. B1j toetreding tot de arbeldsongeschikthetdswet vormen de 50- tot 54-jarigen verhoudingsgewijs de grootste categorle (19\%) en die tussen de 15 en 19 jaar de kleinste (12). In 1986 was meer dan $65 \%$ van de arbeidsongeschikten 45 jaar en ouder; b1jna $40 \%$ was ouder dan 55 jaar. Beëindiging van de arbeidsongeschiktheidsregeling vindt in volgorde van afnemende belangrijkheid plaats door pensionering, herstel en overlifden. Na 10 jaar blifkt slechts $21 \%$ van de arbeldsongeschikten het werk hervat te hebben.

Werklozen komen eveneens over alle leeftijden verspreid voor. Hoe ouder de mensen zifn, des te lager is het percentage dat werkloos ls: 
In 1985 clrca $45 \%$ wan degenen jonger dan 19 faar werkloos; tussen de 50 en 54 Jair was clrca $12 \%$ werkloos. Hiettemin blijkt dat, naarwate de leeftijd stijgt, de duur van de werkloosheld aanzienlijk toeneemt. Rula $70 \%$ van de werklozen ouder dan 50 jaar 1 is meer dan Een jaar zonder werk, tegenover $37 \%$ van de werklozen jonger dan 23 jaar. Blj alle leeftijdscategorieën is de gemiddelde duur van de werkloosheld toegenomen in de periode wan 1975 tot 1985.

De lagere sociaal-economische strata zijn bij werklozen enigszins, en bij arbeldsongeschikten in belangrijke mate oververtegenwoordigd vergeleken met werkenden. Vervroegd gepensioneerde mannen, bestaande ult vroeg gepensioneerden en vervroegde ulttreders, behoren in verge11jk1ng met werklozen en arbeldsongeschikten tot hogere sociaal-economische strata. Zif wjken nlet opvallend af van de werkenden (zie ook CBS, Stat1stisch Magazine, 6,4,86). De vervroegd gepensioneerde vrouwen komen op dit punt overeen met de arbeldsongeschikte vrouwen. Het lijkt erop dat zowel het aantal werklozen als het aantal arbeidsongeschlkten de latste jaren stabiliseren. Naar verwachting zal het aandeel vervroegde utttreders onder de vervroegd gepensioneerden in de mabije toekomst afnemen, gelet op de te verwachten aapassingen van de CAO's op dit punt.

Tengevolge van werkloosheld, arbeidsongeschiktheid en vervroegde pensionering werkte in 1982 nog slechts $40 \%$ van de mannen tussen de 60 en 65 jaar (bij de vrouwen was dit in $19827 \%$ ).

Gelet op de gerlnge kans op werkhervatting onder (vooral oudere) langdurlg werklozen en oudere arbeldsongeschikten mogen we veronderstellen dat het antal werkenden boven de 60 jaar niet zal toenemen. Dit betekent dat de leeftijd warop het definitieve arbeldsloos bestaan beglnt steeds vaker afwijkt van de formele pensioengerechtigde leeftijd van 65 jaar. 


\section{Niet Werken en Gezondheid}

3.1 Inleiding

In onderzoek in verschillende landen komt men tot de conclusle dat niet werken en de dreiging het werk te verliezen met zowel het sociaall functioneren, het welbevinden als de gezondheld negatief samenhangen. Dit vormt voor ons de aanlelding fin dit hoofdstuk twee vragen centraal te stellen: de eerste behelst de rol van ongezondheid als oorzakelijke factor voor het niet werken in de drie voor dit onderzoek relevante categorieën, de tweede betreft de gevolgen voor de gezondheid van niet werken in dezelfde drie categorleën. De eerste vraag komt in paragraaf 3.2 an de orde; de tweede in paragraaf 3.3 .

Het behulp van literatuur over de voor ons relevante categorieën arbeidsongeschikten, werklozen, vervroegd gepensioneerden en werkenden zullen we in het navolgende nader op deze twee vragen Ingaan.

Het ligt voar de hand te veronderstellen dat onder alle onderscheiden categorieën, $65 \mathrm{k}$ onder werkenden, ongezonde mensen te vinden $z 1 j n$. Onder arbeldsongeschikten zal het percentage ongezonden het hoogst zijn, gelet op de oorzaak van het zonder werk geraken. Mogelijk heeft het zonder werk zijn verdere negatieve gevolgen voor de gezondheid. Het percentage ongezonden onder werklozen zal gelijk zijn aan, dan wel lets hoger zijn dan dat onder werkenden, ten gevolge van het gemls van betaalde arbeld. Of een minder goede gezondheld mede tot werkloosheld leidt, dlent ook nader bekeken te worden. Wat vervroegd gepensloneerden betreft, kunnen we vooralsnog geen reden bedenken waram onder hen mér ongezonden zouden zija dan onder werkenden.

In hoeverre vanuit de literatuur deze veronderstellingen ondersteund dan wel verworpen moeten worden zullen we nader bezlen. In paragraaf 3.4 . staan we st11 bij de vraag wat in de verrichte 
onderzoken zoal onder gezondheld verstaan wordt. Verschillende uitkomsten kunned 1mers ook te maken hebben wet onderscheiden wijzen watop gezondheld omschreven en geoperationaliseerd is. In paragraf 3.5. vatten we de bevindingen samen.

\subsection{Ongezondheld als oorzak van niet werken}

\subsubsection{Inletding}

Zlekte en/of gebrek vormen bij arbeldsongeschlkten de primalre oorzaak van het nlet werken. Een klein gedeelte van hen heeft door de aandoening zelfs noolt betalde arbeid kunnen verrlchten (1n 1981 was dit $3,4 \%$ van de totale instroom van nieuwe arbeidsongeschikten). Het merendeel der arbeldsongeschikten is langdurig ziek geworden tijdens de arbeidsloopbaan.

B1j werklozen en vervroegd gepensioneerden is de officlële oorzaak van het nilet werken daarentegen primalr sociaal-economisch van aard. Bij de eerste categorle is het niet werken opgelegd, terwijl het bij een gedeelte van de tweede categorie een vrlje keuze is. We zouden met deze vaststelling kunnen volstaan, om daarmee vervolgens deze paragraaf af te slulten, ware het niet dat we in de literatuur uitspraken vinden, op grond warvan we ons tenminste moeten afvragen of bij arbeldsongeschlkten zlekte of gebrek de enige oorzaak van het niet werken 1 : een gedeelte van de arbeldsongeschikten zou immers volgens sommigen als werkloos bestempeld kunnen worden (o.a. Van Praag en Emanuel, 1981). Tevens moeten we ons afvragen of, vooral bij reorganlsatie, een minder goede gezondheld voor werklozen de ontslagreden kan zifn.

Ook over vervroegd gepenstoneerden vinden we opvallende uitspraken. Zo wordt het dalend antal intreders tot de arbeidsongeschiktheldswet sedert 1981 in verband gebracht met de toename van het aantal mensen dat van vUT-regelingen gebruik makt. Daarmee voork6men zij dat zij als arbeldsongeschikten met betaalde arbeld moeten ophouden (Ministerie van Sociale Zaken, 1981).

Het bovenstaande zou kunnen Impliceren dat: 
- onder arbeidsongeschikten mensen zijn die eigenlijk onder de werkloosheidswet zouden moeten vallen ("verborgen" werklozen onder arbeldsongeschikten);

- onder werklozen mensen zijn die minder arbeidsgeschikt of misschien zelfs arbeidsongeschikt zijn ("verborgen" arbeidsongeschikten onder werklozen);

- onder vervroegd gepensioneerden mensen te vinden zijn die elgenlijk al arbeidsongeschikt zijn, of aan het worden zijn ("verborgen" arbeidsongeschikten onder vervroegd gepensioneerden);

- onder werkenden nawwelijks ongezonden zijn. Onder invloed van de economie zou er sprake $z i j n$ van een toenemende afstoting van minder gezonde en ongezonde werknemers via werklooshelds- en arbeldsongeschiktheidswetten.

In a1 deze gevallen vormt de relatie tussen de gezondheidstoestand voorafgaande aan het niet werken en de aard en de mate van niet werken het probleem.

Op alle punten gaan we hieronder afzonderlijk in.

\subsubsection{Verborgen werklozen onder arbeldsongeschikten}

De eerste twiffel betreft de vraag of er verborgen werklozen zijn onder de arbeldsongeschikten (en zo ja hoe groot dit aantal bij benadering 1s). Dit zou betekenen dat soclal-economische factoren en niet gezondheldsfactoren bij deze arbeldsongeschikten de oorzaak van het niet werken $z i j n$.

In de vakliteratuur wordt erkend dat er sprake 18 van een aanzienlijke verborgen werkloosheld onder arbeldsongeschikten. Circa de helft van de arbeldsongeschikten zou restcapacitelt voor betalde arbeld hebben. Op grond van hun aanzlenlifke medische handicap zouden de voor hen geschikte arbeldsplaatsen evenwel niet toegankelljk zijn (Hunfeld, 1980). De discussie gaat echter niet zozeer over verborgen werkloosheid, maar over verborgen werklozen. Dit zijn mensen die ten onrechte een arbeidsongeschiktheidsuitkering hebben. De bewering dat het om aanzlenlijke aantallen zou gaan - de maximale schatting is $50 \%$ van alle arbeidsongeschikten (Hermans, Sas, Schraven, 1986) - wordt echter 
fel betwit. Toch heeft de overheld har beleldsuitspraken in 1984 hlerop gefundeerd: "ult recente onderzoken kan worden afgeleid dat het antal geheel of gedeeltell jk werklozen blnnen arbeidsongeschiktheidsregelingen aanzlenlijk is" (Begroting Soclale Zaken, 1984 "p.67). Met deze ultsprak anticipeerde de verantwoordelijke staatssecretaris al in 1983 op 1ngrifpende wijzigingsvoorstellen voor soclale zekerheld, die volgens de planning van 1983 in 1985 moesten ingaan (De Graf, 1983).

De redenering achter genoemde vaststelling berust op de constatering dat in bedriffstakken en arbeldssituatles waar een daling optreedt van de werkgelegenhe1d, een toename geconstateerd wordt van het aantal WAO-uitkeringsgerechtigden. Er zijn een aantal gefundeerde protesten gekomen tegen bovenstaande conclusies (Hunfield, 1980; Kruidenier, 1980; Groothoff, 1980). Genoemde auteurs bestrijden de uitspraak dat werklozen en arbeldeongeschikten onderling ultwisselbare categorleën vormen; zij wijzen op de slechte gezondheid, hoge medische consumptie en ongunstige sterftecljfers van arbeldsongeschikten in vergelijking met werklozen. Zo is het aantal ziekenhuisopnames onder arbeidsongeschikten bijna 2,5 keer zo hoog als onder werklozen en werkenden; bovendien 1 s de verpleegduur 3,5 keer zo lang. De sterftekans van mannelijke en vrouwelijke arbeldsongeschikten bleek in 1975 respectievelijk 5 en 9 keer zo hoog als van naar leeftijd vergelijkbare niet WAO-ers. Niettem $\mathbb{1}$ is de sterfte van arbeidsongeschikten in de periode 1968-1982 aanzlenlijk gedaald, zowel per leeftijdsgroep als per geslacht en per jaarcohort arbeldsongeschikten. Groothoff vermeldt in 1986 dat de sterftekans bif blifvend arbeldsongeschikten in verhouding tot vergelijkbare Nederlandse landgenoten bijna drie maal zo hoog is. Opvallend in dit verband is de constatering dat de verhoogde sterftekans voor alle WAO-diagnosen geldt en niet beperkt is tot de sterfte als gevolg van nleuwvormingen of hart- en vaatziekten (Groothoff, 1986).

In de kritlek die gegeven wordt op Van den Bosch en Petersen wordt ook gewezen op manco' In het gehanteerde model; tevens worden vraagtekens gezet bif de toepassing van het model, de operationalisatie en de interpretatie (Kruldenier, 1980). 
Ook andere onderzoekers hebben zich met ziekten onder arbeidsongeschikten bezig gehouden. Zo stellen Philipsen en Halfens (1983) het volgende: "wile op het niveau van het individu nagaat welke weg iemand te gaan heeft voordat hij arbeidsongeschikt wordt verklaard, kan niet goed inzlen hoe men van buitenaf zou kunnen ingrijpen in langdurige ziektegeschiedenissen, langdurige zlekmeldingen en het stelsel van deskundige oordelen warop vaststelling van arbeidsongeschiktheid wegens ziekte of gebreken berust. Er is sprake van een paradox. Op een bovenindividueel niveau bestat een verband tussen arbeldsongeschiktheid en werkgelegenheld. Op individueel niveau vindt een proces van medische beoordeling en bepaling van arbeidsongeschiktheld plaats, waarover veel te zeggen valt, maar nlet dat er de hand mee wordt "gelicht" (pag.162).

Philipsen en Halfens wijzen op de theoretische eenzijdigheid van een macro-economische benadering. Op basis van hun onderzoek uit 1981 houden zij een pleidool om aanvullend onderzoek te doen teneinde tot een evenwichtige beoordeling te komen. In een door henzelf ultgevoerd onderzoek vonden $21 \mathrm{j}$ ook dat arbeidsongeschikten, in tegenstelling tot werklozen "echt" ongezonde mensen zijn.

De aanwezigheld van een groot aantal werklozen onder arbeldsongeschikten zou erop wijzen dat de bepaling van arbeidsongeschiktheid onzorgvuldig gebeurt. Dit lijkt onwaarschijnlijk, omdat de aard van de WAO-voorzlening zodanig is, dat alleen zlekte de oorzaak van niet werken kan zijn (Hermans, Sas, Schraven, 1986). Hooguit kunnen in tifden van laagconjunctuur mensen met langdurige zlekten of chronische aandoeningen eerder "klezen voor" of "aangespoord worden tot" een WAO-carriere. Dat de functie van arbeldsongeschiktheld en partide arbeidsongeschiktheld onder invloed van veranderende politieke en economlsche omstandigheden verschulft, wordt door niemand bestreden. ook Wiersma concludeert dat de toetreding tot de WAO primair door ongelifkheid in gezondheid en in ziektegedrag veroorzaakt wordt, daarb1j aantekenend dat de sociaal-economische situatie ormiskenbaar mede een rol speelt (Wiersma, 1980).

Tot slot achten we het vermeldenswaard dat de meeste arbeidsongeschikten graag betaald werk verrichten (Merens-Rledstra, 1981). Welk gedeelte van deze arbeldsongeschikte werkwiligen zich bij arbeidsbureaus ingeschreven heeft is niet bekend. Zij hebben $\mathrm{in}$ leder geval 
niet de plicht zich aan te melden bij de arbeldsbureaus, en als zij zlch anmelden hebben zif niet de plicht te zeggen dat zij arbeidsongesch1kt $z 1 j n$. Waarschljnl1jk stat dan ook een gedeelte van de niet werkenden "dubbel geboekt", namelifk als arbeldsongeschikte en als werkloze. Het gat niet an deze arbeldsongeschikten als "verborgen" werklozen te beschouwen.

Alleg overzlende is het aanmemelijk dat arbeldsongeschikten als regel echt ongezond $21 j \mathrm{n}$.

\subsubsection{Verborgen arbe1dsongeschikten onder werklozen}

Over de "arbeidsongeschikte" werklozen is weinig bekend. Zo is het ondulde11jk welk deel van de "minder geschikte" werklozen (in 1981: 17\% van alle werklozen - Spruit 1984) minder geschikt is vanwege ziekte en welk deel vanwege bijzondere soclale of persoonlijkheidskenmerken ("nlet bemlddelbaar"). Schultemaker geeft aan dat over de categorie "minder geschikt" geen sluitende definitie bestaat, met het gevolg, dat de toekenning van dit etiket door arbeldsbemiddelaars op vrij arbitraire wijze tot stand komt (Schuitemaker, 1981).

"Arbeldsongeschikte" werklozen zijn waarschijnlifk mensen die vanwege hun zlekteverzuim-verleden bij reorganisaties als eerste ontslagen worden, of niet arbeldsongesch1kt verklaard zijn na een faar ziektewet terwijl zij dat mogelljk wel waren. We moeten de mogelijkheid openlaten dat er ook een deel is dat ten gevolge van werkloosheid ziek geworden 18, wanneer we tenminste de ultspraak "werkloosheid kan tot zlekte lelden" serjeus nemen. Het aantal "arbeldsongeschikte" werklozen $1 \mathrm{~s}$ ons nlet bekend. Zij zouden geheel of gedeeltelijk teruggevonden kumnen worden onder werklozen dle zlch frequent zlek melden op het verplichte perlodieke reglstratleformulier en derhalve gedurende de perlode van de zlekmelding nlet bemlddelbaar $21 \mathrm{fn}$.

Dat het zlekteverzuim-verleden een rol speelt bif ontslag werd vastgesteld door Kruldenter en Bakker (1985). Zij rapporteerden na een studle over het zlekteverzulm van 1977 tot 1983 de volgende bevindingen: mensen die niet via de WAO, mar op andere wijze ontsiagen werden, hadden over dezelfde perlode een aanzienlijk hoger zlekteverzuim dan degenen die hun werk behielden. Het merendeel was het werk 
kwijt geraakt via de werkloosheidswet, een minderheld via vervroegde pensionering.

Verkley en spruit (1987) constateerden moeilijke reintegratile bij minder gezonde werklozen van 30 tot 50 jaar. Zij bleken vaker dan werkenden in dezelfde leeftijd om gezondheidsredenen van baan veranderd, ontslagen, of langdur1g zlek te zijn geweest. Ook was woor hen vaker een WAo-keuring aangevraagd toen $z 1 \mathrm{f}$ nog werkten. Tazelaar en Sprengers (1986) kwawen tot dezelfde bevindingen bij oudere werklozen: $57 \%$ van de gezonde categorle vond binnen een jaar weer nieuw werk, tegenover $25 \%$ van de minst gezonde categorie. Dit alles bevestigt dat gezondheld zowel een negatieve rol speelt in het behouden/verliezen van werk als 1 in het vinden van nieuwe arbeld, wanneer deze weggevallen 18.

Bartley (1985) Wist erop dat selectie door werkgevers op gezondheld een grotere rol gat spelen, narmate de economische situatie slechter wordt.

Deze bevindingen bieden derhalve een belangrijke Indicatie dat een minder goede gezondheld (mede) een oorzakelijke rol kan spelen bij het werkloos worden. Het $11 \mathrm{jkt}$ erop dat verborgen arbeidsongeschikten onder de werklozen een klelne deelcategorle vormen.

3.2.4 Verborgen arbeldsongeschikten onder vervroegd gepensioneerden

over de mogelijke "arbeidsongeschiktheid" onder vervroegd gepensioneerden $1 \mathrm{~s}$ weinig bekend. Desondanks worden hlerover opvallende uttspraken gedaan. Somulge auteurs veronderstellen dat de terugloop van het aantal arbeldsongeschlkten terug te voeren is op de toename van het antal vervroegd gepensloneerden. Dit impliceert dat potentieel arbeldsongeschlkten gebrulk maken van vuT-regelingen. We presenteren daarom een tabel op grond warvan dit volgens het Ministerle van Soclale Zaken aannemel1 jk gemaakt wordt.

We zien dat na 1975 het aantal mensen dat tot de WAO toetreedt afneemt en het amtal mensen dat gebruik makt van de vuT-regeling groeit. Het Ministerie van Soclale Zaken stelt dat de afname van het antal arbeidsongeschikten hoogstwaarschijnlijk het gevolg is van de toename van het antal vervroegd gepensioneerden (Ministerle van sociale Zaken, 1981). Hiertoe worden twee redenen aangevoerd: 
- VuT-ers kunnen geen gebrulk maken van de WAO, omdat $z 1 j$, eenmal in de VUT zifnde, nlet meer volgens de HAO verzekerd (kunnen) zijn;

- toetreding tot de VTT drukt het aantal WAO-verzekerden.

Tabe1 3.1 Vergelijking tussen ontwlkkeling VuT en WAO.

toegetreden tot de toegetreden tot de WAO
vur*

1974

1975

1976

1977

7.300

$\begin{array}{ll}- & 9.000 \\ - & 8.400\end{array}$

1978

3.000

6.800

1979

4.000

6.300

9.000

5.900

* = Schatting GITP

** - Schatting door Mn1sterle

Bron: Vervroegde uftreding in ontwikeling, Ministerie van Soclale Zaken, 1981, p.44

Werknemers die nog geen gebruik mogen maken wan de VuT komen, zo zij het werk willen beëlndigen, voor "de keus" te staan of toe te treden tot de WAO of het nog twee jaar vol te houden en dán gebruik te maken van de VUT. Mede omdat de VUT soclaal gemakkelijker geaccepteerd lijkt te worden dan de WAO, zou men voor df laatste klezen. Langs deze weg, aldus het Ministerle, ontwikkelt de VUT zich tot op zekere hoogte tot een gedeeltelijk alternatief voor de WAO.

Hoewel vorenstaande redener1ng op het eerste gezicht acceptabel 11 jkt, komt het ons voor dat te snel geconcludeerd wordt dat de VUT op zekere hoogte een alternatleve WAO-regellng is. Woor deze reserve $z i j n$ eveneens twee redenen aan te voeren:

- het antal toetredingen tot de arbeidsongeschiktheldswet daalde al voordat de vUT-regeling van kracht werd (1975-1976);

- aan intrede tot de WAO gaat tenminste eén jaar verzuim wegens ziekte vooraf. Hoewel een zekere beslissingsurijheid aan het (permanent) zlek melden ten grondslag 1 igt, is de individuele beslissingswrijheld klelner marmate de aandoeningen objectlever, acuter en ernstger van aard z1jn (Philipsen, 1969, p.63). Derhalve 11jkt het enigszins gewaagd en ongenuanceerd te stellen dat werknemers van 61 en 62 jaar de keuze hebben tussen WAO en VUT. Zo dit wel het geval was, zouden vervroegd gepensloneerden zlch moeten onderscheiden van degenen die op dezelfde leeftijd blifven werken door een hoger ziekteverzulm voor het vertrek. Dit zullen we hleronder nader bezien. 
Uit antwoorden van werkgevers (bouw, metaal en havens) op de vraag of werknemers die wel en geen gebrulk maken wan de VUT-regeling, onderling verschilden in zlektefrequentie, bleek dat daar nauweldjks sprake van was. In de bouw en metal vertoonden de aspliant vuT-ers zelfs een wat lager ziekteverzuim (VUT, 1981).

De antwoorden op de vraag, gericht an werknemers verdeeld naar aanstaande en nlet aanstaande vervroegd gepensioneerden (blijvers), of men na het zestigste jaar wegens ziekte het werk verzuimd heeft, zijn weergegeven in de volgende tabel.

Tabe1 3.2 Ziekteverzulm volgens de werknemers $(\%)$.

\begin{tabular}{|c|c|c|c|c|c|c|c|c|}
\hline \multirow{2}{*}{$\begin{array}{l}\text { ooit ziek } \\
\text { geweest } \\
\text { na 60e jaar }\end{array}$} & \multicolumn{3}{|c|}{ bouw } & \multicolumn{2}{|l|}{ metaal } & havens & \multicolumn{2}{|r|}{ onderwijs } \\
\hline & VUT & blijuers & VUT & blijvers & VUT & blijvers & VuT & blijuers \\
\hline $\begin{array}{l}\text { Ja } \\
\text { neen, nooit }\end{array}$ & $\begin{array}{l}53 \\
47\end{array}$ & $\begin{array}{l}69 \\
31\end{array}$ & $\begin{array}{l}40 \\
60\end{array}$ & $\begin{array}{l}62 \\
38\end{array}$ & $\begin{array}{l}27 \\
73\end{array}$ & $\begin{array}{l}35 \\
65\end{array}$ & $\begin{array}{l}32 \\
68\end{array}$ & $\begin{array}{l}45 \\
55\end{array}$ \\
\hline totaa 1 & 100 & 100 & 100 & 100 & 100 & 100 & 100 & 100 \\
\hline
\end{tabular}

Bron: VUT, vervroegde ulttreding in ontwikkeling, 1981 p.46

Voor alle bedrijfstakken is de conclusie dat anstaande vUT-ers volgens eigen zeggen gezonder zijn, althans minder verzuimden wegens ziekte, dan de blijvers. Het gebruik maken van de vuT-regeling hing in de hier onderzochte populatie nllet samen met ziekteverzuim. Vermoedelifk behoort dus slechts een klein gedeelte van de vervroegd gepensioneerden tot de potentielle arbeidsongeschikten.

Bezien we de resultaten van een onderzoek bif de PTT onder uittreders (c1rca 400 werknemers) en niet-ulttreders (c1rca 300 werknemers) dan blijkt dat belde groepen niet verschillen in gerapporteerde ervaren gezondheid. Wel rapporteren de ulttreders het Jaar voorafgaand aan de ulttreding meer verzulndagen wegens zlekte dan nilt-ulttreders (Janssen en Kools, 1981).

Een ander ons bekend onderzoek betreft een populatile van 2.000 werknemers ult een groot bedrijf, die gedwongen werden van de VUT gebrulk. te maken. Voor het vertrek van deze werknemers hebben artsen de gezondheld vastgesteld, evenals die van een gematchte groep niet-ulttreders. Dok hier bleek nauwelijks sprake van verschillen tussen belde groepen te zifn (Durinck, Kijlstra-ten Theije, 1986). 
Er lijken voldoende redenen om aan te nemen dat het merendeel der vervroegd gepenstoneerden geenszins verborgen of potentieel arbeldsongesch1kt 1s. Werknemers, werkgevers en deskundigen (artsen) $11 j k e n$ hlerin overeen te stemen.

\section{2 .5 Ongezonde werkenden}

De ultspraak dat er gezonde en ongezonde werkenden zijn, zal nlemand verbazen. In de literatuur over het ziekteverzuim komt onder meer naar voren dat het verzulmpercentage tussen 1949 en 1980 ongeveer verdubbeld $1 \mathrm{~s}$ (van 4,6\% naar 9,7\%). De verdubbelingsfactor zou voor alle leeft1jden en woor alle beroepen gelden (Luyckx, 1982). Toch mogen we verwachten dat screening van alle mensen die een betaalde werkkring hebben tot een aanzieniljk hoger percentage dan $10 \%$ zieken zal leiden. In een Dults onderzoek kwam naar voren dat, na screenting van 50.000 werkende mensen in loondienst, 1,5 $\mathrm{z}$ van hen direct 1 n het ziekenhuis opgenomen moest worden en dat een groot deel van de overigen voor nader onderzoek verwezen werd naar huisarts of spectalist (BadenWürttenberg, 1970). Dit zou er op wijzen dat mensen vaak kfezen voor ziek doorwerken (Huysmans, 1973).

Bramlage (1962) kwam tot de conclusie dat het percentage zieke doorwerkers in de leeftijdscategorle van 45-65 jaar $42 \%$ bedroeg. Ook Philipsen constateerde op basis van vele onderzoeken dat zieke doorwerkers een owvangrijke categorle vormen (Ph111psen, 1969). Soeters vermeldde dit ook in 1983. Hij kwam tot de volgende uitspraak: "men dient te bedenken dat de recente daling van het zlekteverzuim, gezondheldsbedrelgende effecten voor werknemers kan hebben". Zo wordt gesuggereerd dat de sterke stijging van de werkloosheid na 1979 een sterke verzulmbeperkende Invloed heeft (Smulders, Van Leeuwen, Van Nooten, 1983). Dit zou betekenen dat het aantal zieke doorwerkers de afgelopen faren mogel1jk toegenomen 1s; aan de andere kant kan de ultstoot van minder gezonde werknemers via werkloosheld- en arbeldsongeschlktheidswet ertoe bljdragen dat relatief veel zleke doorwerkers afgevloeld zifn. Herblj gaan we ult van de vooronderstelling dat zleke doorwerkers tot minder goede arbeldsprestaties komen en om die reden tezamen met de veel verzulmers grotere kans op ontslag hebben. 
Kortom: er zijn ongetwijfeld zleke mensen onder degenen die een betaalde werkkring hebben. Zij zullen een niet geringe minderheld onder de werkenden vormen.

3.3 Ongezondheld als gevolg van nlet werken

\subsubsection{Inleiding}

In dit gedeelte inventariseren we gegevens uit de literatuur over de invloed van het niet werken op de gezondheld. De meeste gegevens zijn ontleend aan buitenlandse literatuur over werklozen.

Het valt aiet te verwachten dat het ongewild verliezen van betaalde arbeid op den duur tot een verbetering van de gezondheld leidt; het tegendeel ligt eerder voor de hand. Niet werken is immers in onze samenleving een ongewenste situatie; we mogen dan ook veronderstellen dat gedwongen niet werken bij de meeste mensen die het treft gepaard gat met identiteitsverlies. Dit verlies kan als indicator gezien worden van een verslechterde psychische of mentale gezondheld. We mogen echter niet ultsluften dat er vooral onder arbeldsongeschikten een deelgroep is bij wie niet werken de gezondheid positief beinvloedt.

Voor een deel der arbeldsongeschikten zou immers kunnen gelden dat juist door het wegvallen wan het werk sprake 1 s van een herstel in het evenwicht draglast-draagkacht; het mogelifike identiteltswerlies ten gevolge van het wegvallen van de soclale functles van werk zou mogelijk gecompenseerd kunnen worden door het bevrifd worden van te zware arbeld en de medische legltimatie van het niet werken.

Voor mensen die vrijwillig vervroegd ultgetreden zljn, kan er zelfs sprake zijn van een identiteltswinst, omdat zij kunnen terugzien op een langdurige loopbaan en owdat het "met de VUT gaan" mogelifk gepaard gat met een aureool; terugtreding ult het arbeldsproces zou immers Impliceren het beschlkbar stellen van de eigen arbeldsplats voor jonge werklozen. Dat hiervan in de praktijk weinig blijkt terecht te komen, doet nlets af aan het feit dat de VUT-regelingen mede vanult deze achtergrond gepresenteerd zijn. Aan de andere kant zullen we in 
de paragraf over VuT-ers zlen dat er $66 \mathrm{k}$ mensen $21 \mathrm{jn}$ die verplicht waren van deze regelling gebrulk te maken. Verder weten we dat onder de rubrlek "vervroegd gepensloneerden" mensen zijn die vanwege het berelken van de pensloengerechtigde leeftijd v66r het 65 e levensjaar, het arbeldsveld moesten rulmen. Identiteltsverlies $11 \mathrm{gt}$ voor hen niet zozeer voor de hand ondat blj de intreding in het arbeidsproces reeds bekend was dat, bijwoorbeeld op 55-jarige leeftijd, het pensioen zou ingaan.

Gegeven onze veronderstelling dat onder werklozen wel, onder arbeidsongeschikten in zekere mate en onder vervroegd gepensloneerden gến sprake 1s van 1dentiteitsverlies, verwachten we dat niet werken voor de eerste categorie wel, voor de tweede categorie in zekere mate en voor de derde categorle geén negatieve gevolgen heeft voor de gezondheid.

In paragraaf 3.3 .2 komen de arbeidsongeschikten aan de orde, in paragraaf 3.3 .3 de vervroegd gepenslioneerden en in paragraaf 3.3 .4 de werklozen.

\subsubsection{Arbeldsongeschikten}

Over de invloed van het niet werken op gezondheid bij arbeidsongeschikten 1 s vanult de literatuur weinig bekend.

In én ons bekend onderzoek komt naar voren dat arbeidsongeschikten in de loop van de tijd meer last krijgen van hun ziekte (Merens-Riedstra, 1981). Hoewel dit onderzoek zich nlet alleen en niet uitdrukke11jk op gezondheid richt, mogen we deze bevinding niet veronachtzamen. De vraag 1 s echter of de verslechtering inherent is aan de zlekte of handlcap dan wel geconditloneerd wordt door de beleving van het niet werken. Jammer genoeg geven de in de voorgaande paragraaf vermelde bevindingen van Hunfleld, Kruldenler en Groothof inzake de gezondheid van arbeldsongeschikten hieromtrent geen uitsluitsel. Belangrijk is de constatering dat bij voortduring van de arbeidsongeschiktheid, arbeidsongeschlkten in toenemende mate ontdekken dat werken meer is dan alleen een bron van 1nkomsten. Men ervaart vooral steeds meer het gemis van functies van werken zoals sociale contacten, matschappelijke status en wardering, structurerling van het dagelijks leven. Func- 
ties, aldus Merens-Riedstra, die in het leven zonder werk door vrijwel geen enkele alternatieve activiteit vervuld blijken te kumen worden (1981, p.146). Daarnaast heeft men steeds het gevoel dat de tijd niet op wardevolle en nuttige wijze besteed wordt. Daarmee heeft de zlekte een ambivalente plaats in het dagelijks leven: enerzijds legitimeert de zlekte het niet werken naar de bultenwacht, anderzijds brengt de ziekte het besef mee dat daarmee de kans op herintred1ng in het arbelidsproces gering is. Niet werken kan voor arbeidsongeschikten $66 k$ problematisch zijn. De ziekte blijkt om twee redenen ongewenst: in de eerste plaats door de psychosociale en economische consequenties ervan, In de tweede plaats door de lichamelifke gevolgen (MerensRledstra, 1981). Voor veel arbeidsongeschikten 1ijkt te gelden dat "non-employability" een emotioneel negatlef beladen kenmerk is. We veronderstellen dan ook dat het nfet werken het welbevinden van arbeidsongeschlkten (op den duur) negatlef beInvloedt. Mede gelet op de lichamelljke kwetsbaarheld van deze categorle veronderstellen we dat het onwelbevinden vervolgens op de lichamelijke gezondheld een negatieve uitwerking heeft.

Onder de arbeldsongeschikten kunnen er evenwel ook Individuen zijn bij wie het eventuele ldentiteitsverlies minder speelt en bij wie het niet werken geen negatleve invloed (meer) heeft op de gezondheld. Het is zelfs denkbaar dat onder de langdurig arbeidsongeschikten gezonden te vinden $21 j n$ die het medisch loket definttief gepasseerd zijn, voor wie zlekte niet meer het organisatiekader van het leven is en bif wie sprake is van een voorwaardelijke gezondheld. We denken dan met name an degenen die eerder om psychlsche redenen afgekeurd $z$ il $j n$ ondat het werk teveel psychische druk met zich meebracht en an degenen die gestabiliseerd invalide zijn ten gevolge van een ongeval.

Hoewel het zeer warschljnlljk om een klelne deelcategorle zal gaan, dlenen we voorzichtig te zijn deze mensen, wanneer zij zich in een onderzoek als gezonden presenteren, bif voorbat het etiket "verborgen werkloos" toe te bedelen.

Al deze overwegingen laten onverlet onze verwachting dat bij de meeste arbeidsongeschikten ten gevolge van het ontbreken van betalde arbeld de gezondhe1d op den duur negatief belnvloed wordt. 


\subsubsection{Veruroegd gepensioneerden}

Ontrent de (causale) relatle niet werken en gezondheld bij vervioegd gepenoloneerden is vrifwel alets bekend utt de literatur, met name niet betreffende degenen de voor hun 65e jaar de regullere pensioengerechtigde leeftijd bereikt hebben.

Ondat voor vervroegd uitgetredenen (VuT-ers) zou gelden dat ulttreding vr1jw111.g 18 , moeten we anuemen dat het zonder werk raken geenszins problematiach 1s, maar veeleer welkom. Het $11 \mathrm{gt}$ dan ook niet voor de hand dat ulttreding in het kader van de VUT tot een minder goede gezondheld leldt.

Er zijn echter twee deelcategorleen werknemers voor wie de VUT problematisch kan $z \mathfrak{j} \mathrm{n}$ : voor degenen die al dan nlet overeenkomstig de CAO, met vervroegd pensioen moesten gaan en voor hen die het dringend advies krijgen in het kader van ad hoc VUT-regelingen ult te treden. Volgens de CAO geldt verplicht vervroegde penslonering in leder geval voor de grafische industrie (VUT 1981). De tweede groep zouden wij. conform de terminologle van het leger, kunnen betitelen als de "aangewezen vrifwilligers". Volgens een berekening van het Ministerie van Soclale Zaken in 1981 zou de eerste groep een minderheid zija. Bij Philips en de Havenbedrifven was het antal verplicht vervroegd gepensioneerden respectlevel1jk $7 \%$ en $28 \%$ over de perlode 1977 tot 1980 . Voor de drie overige vermelde bedrijven en bedriffstakken (Hoogovens, Bouw en Metaal) bedroeg het gemiddelde percentage 17\%. Ons zijn geen andere studles bekend warin na 1981 onderzoek 18 gedaan naar de mate warin "verplichte" en "geadviseerde" vervroegde penslonering voorkomt.

U1teraard houdt deze verplichting niet automatisch in dat het merendeel van de betrokkenen het ongewenst vindt. Wanneer het vertrek onvifwllig wordt, gaat het karakter van de vuT echter meer 11jken op dat van de arbeldsongeschikthelds- en werkloosheidsregelingen en moeten we wel rekentng houden met eventuele negatleve effecten op de gezondheld. Een verschil is het vrijwel ontbreken van financiele problemen voor vervroegd gepensioneerden. Voor arbeldsongeschikten en werklozen zijn deze aanzlenlijk.

De enfge ons bekende studie naar effecten wan (verplichte) verwroegde pensionering is verricht bij Philips. Twee jaar na de eerste meting 
van betreffend onderzoek (zie 3.2.4) bleek de gezondheid van de ultgetreden groep niet af te wijken van de groep die is blijven werken. Blj belde groepen was wel sprake van een "normale" verslechtering van de gezondheid in verband met veroudering (Durlnck, Kijlstrg-ten Thije, 1986).

Hoewel we de resultaten van deze ene studie niet mogen generalliseren naar alle (verplichte) verwroegd gepensioneerden, is er vooralsnog geen reden om aan te nemen dat vrijwillig of niet vrijwilig ulttreden via de VUT of via regullere vroege pensionering effecten heeft op de gezondheid. Nochtans zijn deze effecten ook niet uit te sludten.

\section{3 .4 Werklozen}

De meeste internationale studies over de Invloed van niet werken op gezondheid hebben vrijwel uitsluitend betrekking op werkloosheid. De vraag of werkloosheid schadelijk is voor de gezondheld is op twee niveaus onderzocht.

Op geaggregeerd niveau worden werkloosheidsciffers en andere vooral economische parameters in verband gebracht met zlekte- en sterftecijfers. Op individueel niveau worden individuen als analyse-eenheid genomen. Hun gezondheid wordt gerelateerd aan de status van het werkloos zijn.

Op elk niveau wordt zowel aandacht besteed aan de directe relatie nlet werken en gezondheld, als aan de indirecte relatie met de leefsituatie als Interventërende factor.

a Studies op geaggregeerd niveau

Brenner deed op geaggregeerd niveau longltudinall onderzoek. Hij bestudeerde in de USA de relatie tussen economische variabelen, inclusief de werkloosheids- en sterftecljfers over een lange periode, namelifk 1909-1976. Sterfteclffers bleken significant samen te hangen met vroegere werklooshe1d: zijn cancluste was dat werkloosheid een uitgesteld effect van 2 jaar had op sterftec1jfers (Brenner, 1980). In de internationale literatuur ifjkt er een zekere overeenstemming te bestaan over de megatieve invloed van werkloosheld op gezondheld, 
hoewel er nawel1 fks mprake is van overeensteming over de vrag hoe slecht de gezondheld van werklozen dan wel 1s. De bevindingen variëren van geestel1jke/psychlsche en Ilchamelijke problematiek tot overlijiden en zelfmoord: "unemployment k111s". Wanneer de term geestelijke gezondheld ruiw geinterpreteerd wordt, blijkt uit onderzoeksbevindingen dat het zelfbeeld of de zelfwardering aangetast kan worden. Deze resultaten worden echter $1 \mathrm{n}$ twijfel getrokken (N1jhuls, Rnipschild, 1982).

De ultspraak "umemployment k1118" baarde wellswaar opzien, maar kwam geenszins ongeloofwaard1g over (Brenner, 1971, 1977, 1979, 1982). Vooral hartzlekten en cirrhose zouden hieraan een aanzlenlijke bijdrage leveren. Naat natuurlifke dood werd ook zelfmoord gesignaleerd. Brenner en anderen onderzoeken sinds 1970 de samenhang tussen economische conjunctuur-ontwikkelingen en ziekte of sterfte. Werkloosheidsclffers wormen hlerbiy indicaties voor economische teruggang, terwijl mortaliteit en morblditelt, alsmede opnamen in ziekenhuizen en psychiatrische Intichtingen, indicaties vormen voor de gezondhell van de bevolking.

Zif constateerden dat vier factoren van Invloed waren op de sterfteclffers In Engeland en Wales in de perlode 1936-1976 (Brenner, 1979):

- de hoogte van het nationaal inkomen als indicatie voor voeding, sanitalre voorzleningen, opleiding en medische technologie;

- werkloosheidsciffers;

- snelle economische groei, welke samengat met instabiliteit en Btrese voor specifleke groepen;

- ultgaven van de overheld in het kader van sociale voorzieningem. Belangrijk voor ons 1 s dat zlj vaststelden dat het werkloosheidspeil op significante wijze positief samenhangt met sterftecijfers.

Gravelle, Kerkhinson en Stern (1981) herhaalden het onderzoek met hetzelfde materlaal. Z1j kwamen tot de constatering dat de samenhang tussen werkloosheld en sterfte niet meer signiflcant was wanneer de perfode ultgebreld werd van 1922-1976. Zij wezen erop dat het door Brenner gevonden verband bijna ultslultend berust op een forse achteruitgang in werkloosheid tussen 1940-1942. Naar aanlelding van de discussles over de tegenstrijdige uitkomsten merkt Warr het volgende op: "aparte analyses van de sterftecijfers gedurende kortere perioden dan de door Brenner onderzochte (en gedurende een langere pertode, 
name11jk 1922-1976) bleken niet in staat ook mar een enkel significant verband met de werkloosheid aan te tonen" (Warr, 1983, p.27). McAvinchey (1984) kwam in zijn onderzoek omtrent schotland tot gedifferentleerde uitspraken. Bij twalf leeftijdscategorieên van mannen vond hij in twee categorieën een positief, en In twee andere categorleẹn een negatief verband tussen werkloosheld en sterte; in de acht resterende categorieën vond hij geen enkel verband. Forbes en McGregor (1984) bevestigden na een herhaling van het onderzoek de juistheid van deze bevindingen van McAvinchey.

Vele auteurs zifn het erover eens dat het onderzoek van Brenner wardevol is omdat het nieuwe stimulansen gaf tot verdere exploratie. Een van de hierult voortvloelende hypothesen is die van Eyer (1977): zlekte en dood zijn in tijden van depressie mede het gevolg van de daaraan voorafgaande stresserende hoogconjunctuur; zowel hoog- als laagconjunctuur zouden bijdragen aan een slechte gezondheid. Hij stelt dan ook voor meer nadruk te leggen op spectfleke doodsoorzaken in plats van sterfte als geheel. Zo zou volgens Eyer dood ten gevolge van verkeers- en bedriffsongevallen vooral in verband staan met een overspannen arbeldsmarkt, omdat daar een aanzlenlifk groter aantal mensen aan het werk is dan in een periode van laagconjunctuur; deze mensen worden blootgesteld aan ongevalsrisico's op strat en extra werkdruk.

We zouden ons ook voor kunnen stellen dat ziekten $66 \mathrm{k}$ en vooral terug te woeren zijn op een periode met een snel dalende conjunctuur. Wanneer de daling lang genoeg aanhoudt 11jkt het aannemel1jk dat voortdurende angst voor mogelijk ontslag, samenhangend wet eventuele reorganlsatle en bedriffssluiting, een belangrijke stressor 1s. Zo zijn er vele interpretaties mogelijk over gevonden samenhangen, terwij1 bij herhald onderzoek blijkt dat ook de ultkomsten lang alet altijd consistent zijn. Dit heeft later geleld tot methodologische kritlek op de zogenaande macrostudies (Spru1t, 1983; WHO, 1983; Nifhuls, Knlpschild, 1982 ; Gravelle, 1984 ).

Zelfs wanneer men in een herhaald onderzoek tot dezelfde resultaten komt is de vraag welke (causale) betekenis hieraan gegeven mag worden.

In de verrichte macrostudies worden ook tal van op zich relevante variabelen betrokken zoals woonomstand1gheden, alcohol- en tabakige- 
brulk, woclale steun, voeding en gezondheldszorgkosten ( 0. a * svensson, zollner, 1981).

Het blljkt moellijk afzonderlijke varlabelen te 1 soleren ondat zij walk met andere vartabelen ale clusters voorkomen. Zo hebben mensen wit lagere soclaal-economische strata vergeleken met die uft hogere strata lagere $10 k o m e n$, een minder goede gezondheld, slechtere behuizlng em minder opleldlng, terw1f1 ze daarenboven vaker en langer werkloos $\mathrm{zlJn}$, meer riskante gewoonten en minder goede voedingsgewoonten hebben. Mogelljk verbchillen de lagere en hogere strata ook in gezondheldsopvattingen, hetgeen weer 1 nvloed kan hebben op hun gezondheidsen zlektegedrag (Halfens 1988).

vermeldensward in dit verband is dat demografische factoren van Invloed 11fken op het zonder werk geraken: ouderen, laag opgele1den en alleenstaanden blifken eerder uit het arbeldsproces te treden dan jongeren, hoog opgeleiden en samenwonenden (CBS, Statistisch magazine, 1986; Warr, 1982; Maassen, 1987; Spru1t, 1987). Tegelijkertijd is er de vraag in hoeverre deze factorea samenhangen met gezondheid en andere hiervoor genoemde vartabelen.

b Kritlek op de studies op geaggregeerd niveau

Resultaten van de hlervoor genoemde studles hebben bijgedragen tot een methodologische en theoretische bezinning over onderzoek naar de causale relatie tussen niet werken en gezondheld. Teneinde greep te krijgen op de causale keten tussen niet werken en gezondheid wordt een ateeds sterker pleldool gevoerd om micro-studies (op individueel nlveau) ult te voeren. Gegeven de complexitelt wan het proces dat op gezondheld inwerkt, beplelt onder andere Gravelle (1985) cross-sect1oneel en longltudinal onderzoek op indivdueel nfveau te verrichten. prospecteve en retrospectieve cohortstudies worden eveneens aanbevolen om beter inzicht te verkrijgen in de causale relatie tussen niet werken en gezondheld (N1jhuis, Knipschild, 1982).

Het tot nog toe verrichte cross-sectionele onderzoek levert weinig signiflcante verbanden op tussen nlet werken en gezondheid. Warr (1983) acht dit verrassend omdat een verband alleen al voor de hand $11 \mathrm{gt}$ vanwege de selectleve uitval: minder gezonden lopen grotere kans zonder werk te blljven, terw1jl gezonden grotere kans hebben opnleuw werk te vinden. 
De invloed van de duur van het niet werken zou bij uitstek in longitudinale studies onderzocht kunnen worden met een groep niet werkenden, aangevuld met werkenden als contrast. Bil zodanig opgezette studies kan immers met meer zekerheld lets gesteld worden over de causale invloed van werkloosheid op gezondheid. In de praktijk echter blijkt dit onderzoek zeer schaars.

Langs deze wegen kan ook kennis vergaard worden over varlabelen dle tot niet werken en gezondheid predisponeren en verschillen die de relatie tussen niet werken en gezondheid doorkrulsen (zoals riskante gewoonten).

In de literatuur vinden we ook pleldooten meer explorerend-beschrigvend en transversaal onderzoek te verrichten om zodoende tot ontwikkeling van gedragsmodellen te komen (Spruit, 1983; WHO, 1983). Tot nog toe zijn weliswar aanzetten gegeven tot gedragsmodellen op deelterreinen, maar getoetste kennis is fragmentarisch. Zo is immiddels bekend dat onder werklozen soclale steun een voorspellende waarde heeft voor gezondheid. Ook is bekend dat mannen van middelbare leeftijd, die de opvatting toegedaan zifn dat zij de eigen situatle kunnen beInvloeden, een betere gezondheid hebben dan die welke van mening zijn dat alleen anderen hun situatie kunnen beInvloeden (Gore, 1978; Krause, Strijker, 1984).

\section{c Studies op individueel niveau}

Gravelle (1985) voert als voorbeeld van goed onderzoek dat van Banks en Jackson ult 1982 aan. Deze onderzoekers hadden een populatle jonge schoolverlaters gevolgd vanaf het moment dat $z \mathbb{1}$ de school verileten tot anderhalf jaar later. Zij kwamen tot de conclusie dat een slechte mentale of geestelijke gezondheld niet oorzaak, maar gevolg 1 s van het werkloos zijn.

Ten onzent wjzen Verkley en Spruit (1987) op basis van een longitudimaal onderzoek erop dat langdurig werklozen in de loop van de tijd een minder gezonde leefwijze rapporteren en een slechtere score krijgen op gezondheldsvragenlijsten. Dit kwam vooral tot uiting in algemene malaise en lichamelijke klachten. $21 j$ constateerden dat de "blifvend" werklozen en "b11jvend" werkenden verder uit elkar groelen. Dezelfde auteurs leggen hun bevindingen nast die van soortgelijk onderzoek in Groot-Brittantë (Warr, 1985) en Zweden (Lev1, Brenner, 1985). Ook daar werden werklozen clrca twee jaar gevolgd. Gemiddeld ging de gezondheid 
van de werklozen in belde landen achterult, hoewel vooral in zweden een klelne deelpopulatle wan de werklozen daarvoor verantwoordelijk was. By een gedeelte was er sprake van ampassing aan de situatie, hetgeen vooral inhield een toenemende vaardigheld in het hanteren van de rol wan werkloze, en afname van de onzekerheld over de reacties en verwachtingen van de mensen ult de omgeving (Warr, 1985).

Belangr1jk daarbij is of werklozen vanult de ongeving steun ontvangen. Soclale steun kan lmmers onwelbevinden ten gevolge van verlies van arbefd helpen opvangen en daarmee zlekte mogelijk voorkomen (Gore, 1978).

In een Nederlands onderzoek onder 750 werklozen in de Randstad (en 750 werkenden ter controle) is an dit onderwerp andacht besteed (Verkley, Spruit 1987). Een klein gedeelte van de werklozen, $17 \%$, ervoer het werkloos zijn eerder als plezlerig dan als problematisch. Deze bevindingen waren conform die van Wezel (1975). Bijna de helft, 47\%, beleefde het niet werken als onplezler1g, maar niet als iets afschuwel1jks, terw1j1 circa Eén derde, $36 \%$, de situatle als zeer problemat1sch ervoer.

Sprult et al. (1987) geven aan dat werkloosheid vaker tot eenzaamheid leldt wanneer men een gering aantal relevante anderen in zijn omgeving heeft en zlch zorgen maakt over zlchzelf en het gezin. Wanneer de kwalitelt van de relaties minder sterk 1s, wordt de eenzaamheld als schrijnender ervaren. Het hebben van zorgen over het niet werken, Inclusief financiele problemen, verkleint de neiglng om anderen op te zoeken en over de situatie te spreken.

U1t een ander onderzoek, waarbij werklozen een faar gevolgd zijn, komt naar voren dat bif het voortschrijden van de tijd dat men zonder werk 1.8 de eenzaamheld $z 1 \mathrm{ch}$ over een grotere groep ultbreidt: ten tijde van ontslag voelde $2 \%$ zich eenzaam en een Jaar later $30 \%$ van degenen die werkloos bleven (Tazelaar, Sprengers, 1984).

Tegen de achtergrond van het vorenstaande concluderen spruit et al. (1987) dat er sterke anwijzingen zijn dat de grotere eenzaamheid onder werklozen aan de toestand van de werkloosheld zelf geweten kan worden.

Soclale steun wordt door Warr (1983) naar voren gebracht als een van de varlabelen die een interveniërende rol blijken te spelen op de causale relatie werkloosheld-gezondheld. Andere varlabelen, die hij op 
basis van een literatuurstudie naar voren brengt, zijn binding aan het werk, leeft1jd, geslacht, duur van de werkloosheld, soclale klasse, financlële druk, niveau van persoonlifke actlvitelten, het volgen van programma's voor werklozen, persoonlijke begelelding, eerdere ervaringen met werkloosheid, de gepercipleerde oorzaak van werkloosheid, het plaatselijke werkloosheidspell en persoonlijke stressgevoeligheld (Warr 1983).

Op individueel niveau is tot nog toe ook welnig bekend over riskante gewoonten van niet werkenden. Daarenboven zijn ultspraken hierover tegenstrijd1g (Warr, 1983; Crawford, Plant, Kreitman, Latcham, 1987). Kennis over deze variabelen geeft de mogelijkheid extra kwetsbare groepen op te sporen om vervolgens voor hen speciale interventieprogramma's te ontwikkelen.

\subsection{Gezondheidsmetingen onder niet werkenden}

Uit voorgaande paragrafen kunnen we concluderen dat (on)gezondheid van niet werkenden op vele manleren geoperationaliseerd is. Een 1llustratieve opsomming van onderschelden wijzen waarop ongezondheid en zlekte onder werklozen gemeten is, vinden we in een overzichtsrapport van Nijhuis en Knipschild (1983). Zij hebben ruim 60 nationale en internationale artikelen geinwentariseeerd, daarbij lettend op de gehanteerde operationalisaties en gebruikte onderzoekmethoden. Op grond van de operationalisaties hebben $z 1 j$ drie hoofdrubrieken gemaakt, te weten geestelijke gezondheid, lichamellfke gezondheld en zlektegedrag. De onderverdeling van geestelljke gezondheld in termen van "gevoellens van doelloosheid", "veranderingen in het self esteem", "soctaal 1solement" en "t1jdsbeleving", 11 lustreert de gehanteerde relkw1jdte van geeste$11 j k e$ gezondheld. De variatie in gehanteerde operationalisaties van (on)gezondheid is dermate groot dat alleen met de ideële definitie van gezondheid, zoals de who hanteert, het geheel omvat kan worden: gezondheld is een toestand van lichamelljk, poychisch en matichappelijk welzijn.

Niet zelden zien we dat de term "gezondheldsproblemen" gehanteerd wordt in onderzoek over werklozen. Een dergelljke term geeft kennel1 fk de rulmte alle aspecten van het menselijk bestaan onder "gezondheld" te laten vallen. Ter 1llustratle geven we het volgende weer: "The 
psychological, economic and soctal comsequences of unemployment (...) can lead to a broad spectrum of health problems in the long run such as deprestion, Alcohol addiction, drag abuse and other chronlc health and soclal conditions leading to chromic vulnerablift" (Svensson, Zollner, 1985, p.1).

Als men deze brede definitle hanteert, dan moet geconcludeerd worden dat werkloo en arbeldaongeschikt zijn tot ongezondheld leidt. Op grond van de vermelde literatuurstudie van Nijhuis en Knipschild moeten we in leder geval ook concluderen dat tot nog toe niet bewezen is dat in tijden van welvart 1 de westerse kapitalistische wereld werkloosheld de 11chamelijke gezondheld beInvloedt. Omdat wij het begrip ongezondheld enigszins willen afbakenen, achten we het van belang de eerder vermelde onschrijving van geestelijke gezondheid niet over te nemen. Aan de andere kant dienen we te voorkomen dat ongezondheld zodan1g afgebakend wordt dat deze ingeëngd wordt tot ziekte in de betekenls wan het met behulp van blomedische bepalingen aantonen van een pathologisch substraat. De kans is dan groot dat we voorbijgaan aan zlekte als beleving. Daarom klezen wlj voor gezondheldsindicatoren met een enigszins objectief en indicatorem met een enigszins subjectlef of belevingskarakter. Daarbilj moeten we ervoor waken dat we zlektegedrag uitsluiten. Ziekte en ziektegedrag zijis immers nauw aan elkaar verbonden. Zlektegedrag is een onvermijdelijke categorie in de beoordellng van lemands gezondheld, hetgeen in gezondheldszorg en samenleving erkend wordt (Philipsen, Halfens, 1983). In het volgende hoofdstuk zullen we de 11 jn van deze keuze verder doortrekken.

\subsection{Conclusies en samenvatting}

In dit hoofdstuk zijn we an de hand van binnen- en bultenlandse 1iteratuur Ingegaan op de samenhang tussen niet werken en gezondheid. Enerzlfds hebben we de invloed van (on)gezondheld op het nife werken, dan wel zomder werk geraken, besproken; anderzijds kwaw de invloed van niet werken op gezondheld ter sprake.

Wat het eerste betreft $11 j k t$ het annemel1jk dat een slechte gezondheid niet alleen tot arbeldsongeschiktheld leldt, maar voor een deel ook tot werkloosheid. Nooral bij reorganisaties blifkt deze relatie een rol te spelen; bif bedrijfssluitingen lijkt dit niet het geval. 
Dat een slechte gezondheld tot vervroegde pensionering leidt, kan niet worden aangetoond en $11 \mathrm{gt}$ ook niet voor de hand. Voorts hebben we nar voren gebracht dat $86 \mathrm{k}$ onder mensen die een betalde werkkring hebben warschljnlijk een niet te onderschatten winderheid tot de zieken behoort.

Het betrekking tot de vraag of nlet werken tot een slechte gezondheid leldt, blijken de bevindingen in de literatur opvallend ulteen te lopen. Dit is mede afhankelijk van de methode van onderzoek en de gehanteerde operationallsatle van gezondheld. Arbeldsongeschikt zijn, beInvloedt warschijnlijk op den duur de subjectieve gezondheld negatief vanwege het gemis aan arbeld, ondanks het medisch allbi. Ook achten we het niet onwaarschijnlijk dat hierdoor de objectleve gezondheld negatief beinvloed wordt, vanwege de lichamel1jke kwetsbaarheid. Werkloos zijn beInvloedt mogelijk de subjectleve gezondheld en niet de objectleve gezondheld. Het is niet denkbeeldig dat een klelne groep minder gezonde werklozen bif onvoldoende steun uit de ongeving op den duur tot een dusdanig identiteitsverlies komen dat $21 \mathrm{j}$ in een neerwartse spiraal van een verslechterende gezondheid terecht komen.

Het ligt niet voor de hand dat het niet werken de gezondheid van vervroegd gepensioneerden beinvloedt.

Samenvattend komen we tot het volgende schema: de linker kolom betreft de vraag of bij de afzonderlijke categorleën gezondheld tot niet werken gele1d heeft. De rechter kolom betreft de vraag of niet werken tot ongezondheid leidt; "Subjectlef" staat voor subjectleve gezondheld en "objectief" voor objectleve gezondheld.

Samenvattend overzlcht: ongezondheid als oorzaak en als gevolg van het niet werken, gedifferentleerd nar niet werkenden en werkenden.

$\begin{array}{ll}\begin{array}{l}\text { ongezond- } \rightarrow \text { niet } \\ \text { held }\end{array} & \begin{array}{l}\text { niet } \rightarrow \text { ongezond- } \\ \text { werken } \\ \text { weid }\end{array} \\ \text { ja } & \begin{array}{l}\text { subjectlef: ja } \\ \text { objectief: mogelljk }\end{array} \\ \text { mogelijk een } & \text { subjectlef: ja } \\ \text { klelin deel } & \text { objectlef: neen }\end{array}$

VUT

niet warschljnlijk

nlet warechijnlijk

werkenden

mogeli jk een klein

R. v.t.

deel ongezond; kan

tot verlies van

werk lelden 
Gelet op de 11teratur-1nventarlsatie en terugkoppelend naar onze veronderstellingen in paragraaf 3.1 kunnen we alet tot preclese ultspraken komen over de relatieve gezondheidstoestand van de drie categorleën niet werkenden en werkenden.

In het voorgaande hebben we ook gezien dat resultaten van onderzoeken op een hoog geaggregeerd niveau bljgedragen hebben tot een methodologigche en Inhoudelijke bezinning over de relatie niet werken en gezondheld. Er bl1jkt duldel1 1 k behoefte aan drie "typen" onderzoek, bij voorkeur op individueel niveau, om inzicht te krijgen in de relatie nilet werken en gezondheld:

1 explorerend-beschrijvend onderzoek om tot ontwikkeling van gedragsmodellen te komen;

2 transversal onderzoek;

3 longitudinaal onderzoek.

Tegen deze achtergrond hebben we, zoals uft het volgende hoofdstuk blijkt, gekozen voor transversaal en longltudinaal onderzoek op microatveau.

Ondat gezondheld niet zelden zodanlg geoperationallseerd is dat ook vele aspecten van het dagelijks leven hieronder vallen, lifkt het aanbevelingswaardig in ons onderzoek over gezondheld en nilet werken, de term "gezondheld" enigszins in te perken op de wijze zoals beschreven 1 paragraaf 3.4 .

Daarnaast achten we het van belang apart aandacht te besteden aan voor de gezondheld riskante gedragingen en sociale particlpatie; beide kunnen lmmers de relatle nlet werken en gezondheld doorkruisen. 


\section{Probleemstelling, Hypothesen en Operationalisatie}

\subsection{Inleiding}

Voortbouwend op de bevindingen in het vorige hoofdstuk vervolgen we in dit hoofdstuk met de probleemstelling, hypothesen en operationalisatie, achtereenvolgens in de paragrafen $4.3,4.4$ en 4.5 .

Voorafgaand geven we mede aan de hand van de eerder besproken literatuut een overzicht van bevindingen en overwegingen die richting en inhoud bepalen van ons onderzoek. Hiervoor is paragraaf 4.2 gereserweerd.

\subsection{Overwegingen die richting geven an het onderzoek}

Tegenstrijdige ultspraken over de onderlinge verschillen in gezondheld tussen de drie categorieen niet werkenden roepen de vraag op in hoeverre de drie etiketten "arbeidsongeschikt", "werkloos" en "vervroegd gepensloneer $d^{\prime \prime \prime}$ onderling lnwisselbaar zijn.

Eerder verwezen we naar ultspraken die aangeven dat het onderachelden van werklozen en arbeldsongeschikten analytisch en irrelevant is.

Gelet op de verschillende oorzaken van het zonder werk geraken en de afzonderlijke voorzleningen waronder de onderscheiden categorieen vallen, mogea we echter verwachten dat de mensen die hieronder vallen verte van gelijk zijn in gezondheld.

Wetenschappelijke uitspraken over gezondheld van arbeidsongeschdkten en werklozen berusten op rapportage van betrokkenen zelf. Deze bevin dingen worden soms in twijfel getrokken (Tazelaar, 1983). Eerder vermelde bevindingen inzake hogere sterftecijfers onder arbeidsongeschikten en hogere cijfers over ziekenhulsopnames (en opnameduur) 
11 Jhen het wantrouwen jegens resultaten op basis van zelfrapportage niet weg te nemen. Zoals arbeldsongeschikten verdacht kunmen worden van overrapportage inzake zlekte en onwelbevinden, zo kunnen werklozen verdacht worden wan "onderrapportage": bij werklozen die graag willen herintreden 18 de kans op trucage nar de "flinke" kant het grootst (Tazelaar, 1983).

Vooral de tegenstrijdige bevindingen in de buitenlandse literatuur over de effecten van werkloosheid op gezondheid geven aanlelding de samenhang tussen de duur van (gedwongen) niet werken en gezondheld in Nederland nader te exploreren. De stuatie in ons land is om meer dan een reden nlet vergelijkbaar met die in het buitenland. Dit komt onder meer door een total andere wetgeving en veelal andere financlële implicaties van het zonder werk geraken. Daarom is meer kennis over de samenhang tussen werkloosheid en gezondheld van groot belang * Wanneer (langdurend) niet werken een dusdanige stressor is dat de gezondheid van betrokkenen negatief beinuloed wordt, is het van belang hiermee rekenlng te houden bij het te voeren (werkloosheids)beleid. Meer inzlcht hierover is vooral van belang omdat Nederland in de westerse wereld een van de landen is met het hoogste werkloosheidscijfer en de langste werkloosheidsduur: in 1986 was zelfs bijna $60 \%$ wan de werklozen langer dan 12 maanden zonder werk (volgens OESO normen).

Indien bijvoorbeeld langdurig werklozen een slechtere gezondheid hebben dan de kortdurig niet werkenden, kan dit ook het gevolg zijn van een negatleve selectle, ondat, zoals eerder vermeld, gezonde werklozen en minder ongezonde arbeidsongeschikten een grotere kans zouden hebben in het arbeldsbestel te reintegreren. Dat zou tot een cumulatie lefden van ongezonden onder de langdurig niet werkenden. Het is denkbaar dat een eventuele slechte gezondheld onder langdurig niet werkenden gedeeltelljk een selectle-effect en gedeeltelijk een effect is van constante en toenemende stressoren die het gedwongen niet werken met zich twee zou brengen.

Uitsluitsel hieromtrent is niet alleen theoretisch van belang, maar kan ook belangrijk zijn wanneer handvatten gezocht worden om de eventuele negatieve effecten van het niet werken te beïnvloeden. 
Een vraag die niet zelden gesteld wordt is deze: heeft het gemis van betaalde arbeid behalve invloed op gezondheid ook invloed op gezondheidsbedreigende factoren als riskante gewoonten en sociaal isolement? Wetenschappelijke kennis hieromtrent kan bok aanleiding geven tot de vraag of het beleid inzake niet werkenden bijgesteld dient te worden.

Een belangrijk discussiepunt is tevens of er sprake is van een naderende twee-deling van de samenleving tussen werkenden en niet werkenden.

Uit het leefsituatie-onderzoek van 1982 komt naar voren dat werkloosheld en arbeldsongeschiktheid de bestaande verschillen met werkenden wel intensiveren, maar dat de invloed ervan niet zo groot is dat van nieuwe scheidslijnen, of zelfs van dichotomisering van de samenleving sprake is (Becker, Vink, 1984).

Het vorenstaande brengt ons ertoe in ons onderzoek de volgende aandachtspunten centraal te stellen.

- Verschilien in gezondheid tussen arbeidsongeschlkten, werklozen en vervroegd gepensloneerden enerzijds en, tussen deze categorleën en werkenden anderzijds;

- Betrouwbarheid van gezondheidsutuspraken door arbeidsongeschikten en werklozen, door deze te vergelijken met uitspraken van (huis)artsen over de gezondheid van dezelfde categorleën op basis van medische dosslers;

- Samenhang tussen de duur van niet werken en gezondheid; in die betekenis dat vastgeste1d kan worden of ongezondheld onder de onderscheiden categorleën langdurig niet werkenden een selectie-effect, dan wel een causaal gevolg van niet werken 15 ;

- Samenhang tussen niet werken enerzijds en riskante gewoonten en particlpatie anderzijds; ook wat dit thema betreft is het van belang vast te stellen of niet werken inwloed heeft op riskante gewoonten en participatie, en zo ja, in hoeverre dit voor alle drie categorieën niet werkenden geldt.

Er zijn uiteraard nog meer relevante aandachtsvelden vast te stellen op het terreln van niet werken. Genoemde onderwerpen zijn, gelet op de literatur op dit terrein, de belangrijkste. De tegenstrijdige opvattingen over de relatie nlet werken en gezondheid én over de beweerde 
onderlinge 1nwlselbatheid van arbeldsongeschikten, werklozen en vervroegd gepensloneerden op basis van gezondheid vragen erom deze onderwerpen centraal te stellen. In hoofdstuk drie vonden we aanwijzingen dat werkloos en arbeldsongeschlkt zijn tot een slechtere (mentale) gezondheid leldt, tot minder soclale contacten en tot meer riskante gewoonten. Het is echter niet altijd duldelijk of selectieve ultval tot een vertekening van de uitkomsten geleid heeft. Crosssectionele onderzoeken wijzen gedeeltelljk op een samenhang tussen werkloos zijn en welbevinden in causale termen, maar we moeten ermee rekening houden dat in de loop van de tijd, nast de verwachte teruggang van het gevoel van welbevinden ook een proces van zelfselectie kan meespelen: "degenen met een hoger niveau van welbevinden kunnen wellicht beter een nieuwe baan vinden, omat zij bijwoorbeeld meer zelfvertrouwen toner In een sollicitatiegesprek" (Warr, 1983).

Tot nog toe is niet angetoond dat werkloosheid en arbeidsongeschiktheid - in de betekenis van geen werk hebben - de fysieke gezondheid negatief beInvloeden, hoewel in het algemeen aangenomen wordt dat dit het geval is (Warr, 1983). Daarnaast zijn er tegenstrijdige uitspraken over zowel maatschappelijke 1solatie van niet werkenden als over de mate warin onder hen voor de gezoncheid riskante gedragingen voorkomen (o.a. Becker, Vink, 1984; Knibbe, 1984).

Vooral longitudinale analyse kan ons meer inzlcht geven hierin. We dienen hieraan toe te voegen dat gegeven genoemde aandachtsvelden de definitieve probleemstelling mede inhoud gekregen heeft door de keuze ons onderzoek gedeeltelijk het karakter te geven van secundalre analyse op bestaand materlaal. Dit betreft de gegevens van de lande11jke studie Nederland Oke die in 1981 en 1983 uitgevoerd is. De keuze van dit materiaal is ingegeven door de volgende overwegingen:

- het betreft een representatieve landelijke steekproef onder niet werkenden en werkenden;

- het materlaal dekt in aanzlenlijke mate de door ons relevant geachte aandachtsvelden;

- het is een panelstudie, wardoor we niet werkenden in de tijd kunnen volgen;

- het materiaal is "in huis", waardoor extra kosten en inspanning, nodig om de gegevens van elders te betrekken, vermeden konden worden. 
Het onderzoeksmateriaal bledt damenboven het yoordeel dat we andere in Nederland oké beschikbare relevante gegevens in relatie tot niet werken, $68 \mathrm{k}$ in het onderzoek kunnen betrekken. Deze gegevens betreffen gezondheidsopvattingen, vooral de beheersingsoriêntatie als bijzondere specificatie hiervan. Deze oriëntatie is gerelateerd aan gezondheid en ziekte én gezondheids- en ziektegedrag. Met behulp hiervan kunnen we vaststellen in hoeverre de afzonderlijke categorleën niet werkenden en werkenden verschillen in opvatting of de beheersing van hun gezondheld aan henzelf dan wel aan anderen of het toeval toegeschreven kan worden. We mogen immers veronderstellen dat de beheersingsorientatie relevant is voor gezondheids- en ziektegedrag, indien gezondheid en zlekte (ook) een motivatie vormt voor het gedrag (Halfens et al, 1988).

De keuze om secundair materiaal te analyseren brengt uiteraard ook nadelen met $z$ ich mee.

Het nadeel van het Nederland oké materiaal is twee-ledig:

- het bestand vrouwen is dusdanig klein dat het niet verantwoord was niet werkende vrouwen in het onderzoek op te nemen. Daarbij was de categorie werklozen gesplitst in twee subcategorieèn, namelijk werkloze vrouwen en werkzoekende huisvrouwen. Werkzoekende huisvrouwen lijken geenszins bij voorbat vergelijkbaar met werkloze huisvrouwen. Belde subcategorieën en die van arbeidsongeschlkten en vervroegd gepensioneerden $z i j n$ dermate klein in aantal dat het verre van verantwoord leek te onderzoeken in hoeverre deze overenkwamen naar relevante kenmerken.

- niet alle gegevens warin men als onderzoeker gelnteresseerd $1 \mathrm{~s}$ z jn aanwezig. Zo hadden we graag de beleving van het niet werken gemeten. Tevens hadden we graag meer indicatoren van soclale participatie in het onderzoek betrokken dan de beschikbare; we denken daarbyj aan de omvang van het sociale netwerk, de daarult ervaren practische en emotionele steun en de wederkerigheid inzake steun. 
4.3 De probleemstelling en omschrijuing van de begrippen

De probleemste11ing is als volgt geformuleerd:

1 Verschillen drle categorleën niet werkende mannen, te weten arbeldsongeschikten, werklozen en vervroegd gepensioneerden, onderlung, en In vergelfjking met werkende mannen naar gerapporteerde gezondheid, gezondheldsopvattingen, riskante gewoonten en particlpatie?

2 Kont zelfrapportage over gezondheld wan niet werkende en werkende mannen overeen met rapportage door hulsartsen aan de hand van medische dossiers?

3 BeInvloedt de duur van het niet werken de gezondheid, gezondheidsopvattingen, riskante gewoonten en particlpatie, en zo ja, in welke richting?

De toegepaste begrippen worden nu nader toegelicht.

- Niet werkenden en werkenden

De onderzoekspopulatie wordt in de eerste plats gedefinieerd door geslacht (mannelijk), nationalitelt (Nederlands) en leeftijd (21 $t / \mathrm{m}$ 64 Jaar), en door de els dat de respondenten niet wonachtig zijn in een instelling van welke aard dan ook (verpleeghuis, penitentiaire inrichting, ziekenhuls, zwakzinnigeninrichting, klooster of kazerne).

Onder werklozen verstaan we in dit onderzoek degenen die geen betaald werk (meer) hebben en werkzoekend zijn. Dit houdt in dat werklozen die part-time werken en een full-time baan zoeken, dan wel betald werk verrichten dat niet of onvoldoende aansluit bij hun opleiding of ervarlng en (beter) passend werk zoeken, niet in het onderzoek betrokken zullen worden.

Arbeldsongeschikten in dit onderzoek zijn degenen die arbeidsongeschikt verklaard zijn op basis van de Wet op de Arbeidsongeschiktheid (WAO), de Wet op de Arbeidsongeschiktheldsverzekering (AAW) en ABPInvalidteltspensloen en geen betaald werk verrichten. Arbeidsongeschikten die voltijds of deeltijds betaald (aangepast) werk doen, sluiten we derhalve uit.

onder vervroegd gepensioneerden verstaan we degenen die nog geen 65 jaar oud zijn en voor hun 65 e levensjaar met pensioen zijn gegaan op 
basis van welke regeling dan ook (vervroegde uittreding, functioneel leeftijdsontslag, eerder pensioen vanwege "tropenjaren" of rentenierschap), zonder dat zij betaald werk verrichten.

Werkenden tot slot zijn alle Nederlandse mannen die betald werk verrichten en niet onder een van vorengenoemde categorieën vallen.

\section{- Gezondheid}

Vooruitlopend op hoofdstuk vijf - methoden en populaties - wijzen we erop dat de vraagstelling, voorzover het gezondheid betreft, beantwoord wordt aan de hand van twee onderzoeken. Het eerste onderzoek gaat uit van gegevens van het eerder vermelde landelijk onderzoek dat in het kader van de actle "Nederland oke" uitgevoerd is "secundaire analyse); het tweede betreft een praktijkpopulatie-onderzoek in enkele hulsartspraktijken die in én gezondheidscentrum ondergebracht $z i j n$. Dit betekent dat gezondheid op twee manieren gemeten is:

- In het landelijk onderzoek wordt gezondheid gemeten met behulp van ultspraken van de respondenten zelf op geleide van door interviewers gestelde vragen. Uitspraken van de respondenten betreffen: aanwezigheid van lichamelijke aandoeningen/handicaps en doktersbezcek (gerapporteerde objectieve gezondheid), lichamelijke klachten, beoordeling van de eigen gezondheid, zelfmedicatie of medicijngebruik op eigen Inttiatief en zorgen over de eigen gezondheid (gerapporteerde subjectieve gezondheid). Zelfmedicatie als indicator voor ziektegedrag relkt verder dan subjectieve gezondheid sec; het betreft het innemen van pljnstllers, norit, laxeermiddelen, slaap- en kalmeringsmiddelen;

- in het praktijkpopulatie-onderzoek wordt de gezondheid van de patiënt vastgesteld op basis van medische dossiers door de hulsarts. Uitspraken van de huisartsen betreffen problemen van de patiënt, die rechtstreeks op diens actuele gezondheld betrekking hebben dan wel een bedreiging van diens gezondheld kunnen vormen. Tevens is ten behoeve van dit onderzoek het aantal arts-patient contacten over 1986 vastgelegd. Rapportage van de hulsarts van gezondheldsproblemen noemen (objectlef) vastgestelde gezondheld. 
- Gezondheldsopwattingen, rlskante gewoonten, participatie en duur van het niet werken

Onder gezondheldsopvattingen verstaan we zowel meningen over het belang dat gezondheid heeft in relatie tot andere waarden, als de beheersingsoriëtatie in relatie tot gezondhelds- en zlektegedrag. Beheersingsorfëntatle kan worden beschreven als een algemene verwachting owtrent wle of wat gebeurtenissen beheerst en in welke mate (Halfens, 1985). Halfens onderscheidt hieraan drie van elkaar onafhankelijke dimensles, namelijk de mate warin men de eigen gezondheld meent te kunnen belnvloeden (Interne beheersingsoriëntatie), de mate warln men meent dat artsen als machtige anderen de gezondheid kunnen beInvloeden (de externe beheersingsorlëntatie ofwel de oriëntatie op machtige anderen), en als derde dimensie, de mate waarin men de opvatting toegedaan is dat gezondheld beinvloed wordt door kans of toeval (kans of toevalsorlëtatie) (Halfens, 1985).

Onder riskante gewoonten verstaan we gewoonten die de gezondhell negatief kunnen beinvloeden. In dit onderzoek worden betrokken het roken van sigaretten, gebruik van alcoholhoudende dranken en het ontbreken van lichaamsbeweging. Hoewel meer riskante gewoonten bij het onderzoek betrokken kunnen worden, zoals verkeersgedrag, hebben we ons tot deze beperkt omdat in de 11teratuur over niet werkenden ultspraken hlerover tegenstrijdig $21 j \mathrm{n}$.

Tot slot zijn we gernteresseerd in particlpatie als operationalisatie van soclale integratie. Gegeven het beschikbare onderzoeksmateriaal hebben we dit in twee richtingen uitgewerkt, namelijk het aantal contacten met mensen in de directe sociale omgeving (familie, vrienden, kennissen, clubgenoten) en particlpatie in breder verband: het stemmen bif verklezingen en lidmatschap van enfg kerkgenootschap.

- De duur van het niet werken

De term "duur van het niet werken" heeft in dit onderzoek twee betekenissen, namelijk een transversale en een longitudinale. Transversaal betreft de vergelijking van kortdurend en langdurend niet werken in 1983 op gezondheld, gezondheidsopvattingen, riskante gewoonten en participatie. 
Longitudinaal betreft de analyse in de tijd (181-'83) warbij we de invloed van de duur van het niet werken vaststellen op gezondheid, gezondheldsopvattingen, riskante gewoonten en participatie.

De begrenzing tussen kort- en langdurend niet werken hebben we gelegd bij 24 jaar. Deze begrenzing werd voornamellijk bepaald door drie overwegingen, waarbij de derde pragmatisch van aard is:

- voor 1 januari 1987 ontstond na $2 \frac{1}{2}$ jaar werkloosheid voor betrokkenen een belangrijke omslag, namelljk die warop zij van de bijstand afhankelijk werden;

- $1 \frac{1}{2}$ tot $2 \frac{1}{2}$ jaar wordt in de literatuur als "gewenningsperiode" aangegeven na het optreden van een "1ife event" (Weeda, 1984);

- de populatie die op het moment van het onderzoek ến jaar of korter zonder werk was, bleek zo gerling in omvang dat uitspraken over de samenhang tussen duur niet werken en gezondheid hachelifk zouden worden, ook al zouden deze statistisch verantwoord blijken te zijn. In de intermationale literatuur over het verloop van welbevinden na het werkloos worden zien we dat tegenstrijdige periodes genoemd worden voordat een dieptepunt in welbevinden optreedt. Niet zelden wordt drie maanden tot een half jaar genoemd in onderzoeken warbij de onderzochten meestal niet langer dan een jaar gevolgd zijn (Warr, 1983).

\subsection{Hypothesen}

Bij elk te bespreken onderwerp, te weten: gezondheid, gezondheldsopvattingen, rlskante gewoonten en participatle hebben we hypothesen geformuleerd. Onze hypothesen vloeien gedeeltelijk voort ult de 11 teratuur die in hoofdstuk 3 besproken is, en gedeeltelijk uit de literatuur die we hierna per onderwerp zullen bespreken.

Per onderwerp onderschelden we drie sets van hypothesen of onderstellingen:

- set 1 betreft onderstellingen over verschillen en overeenkomsten tussen de diverse categorleën niet werkenden;

- set 2 omvat onderstellingen over verschillen en overeenkomsten tussen nlet werkenden en werkenden;

- set 3 betreft onderstellingen over de samenhang van de duur van het niet werken met gezondheld, gezondheldsopvattingen, riskante gewoonten en participatie. 
De hypothesen worden getoetst op basis van transversale en longitudinale analyses. Transwersale analyse betreft de onderlinge vergelijking van kort- en langdurig niet werkenden; de langitudinale analyse betreft de Invloed van de duur van het niet werken.

\subsubsection{Gezondheid}

Gerapporteerde gezondheid

Bij arbeidsongeschikten is een slechte gezondheid de oorzaak van het niet werken. Daarom zullen zij in objectief en subjectlef opzicht een slechtere gezondheld hebben dan werklozen, vervroegd gepenstoneerden en werkenden. Werklozen onderschelden zich op hun beurt weer in subfectleve gezondheid van vervroegd gepensioneerden en werkenden, ten gevolge van het genis aan arbeld en de daaraan, in hoofdstuk 3.3 vermelde, gekoppelde functies. Niettemin liggen de literaturrbevindingen in Nederland niet geheel in dezelfde $11 \mathrm{jn}$. Volgens Van der Zee (1982) hebben werklozen wél een hogere neuratische labllitelt dan werkenden, maar verschillen ze niét in het aantal lichamelijke klachten. Becker en Vink (1984) stellen dat werklozen hun eigen gezondheld iets ongunstiger beoordelen dan werkenden. Omdat naar wij verwachten bij de meeste vervroegd gepensioneerden het gemis aan betaalde arbeid afwezig 15 , mede omdat zij meestal vr1jwillig met werken gestopt zijn, zal hun gezondheid ook op den duur nlet afwijken van die van werkenden. Daarmaast mogen we, gelet op het vermelde in hoofdstuk 3 , aannemen, dat zij zich op het moment van ontslag in gezondheid niet van werkenden onderschelden.

We veronderstellen dat de duur van het niet werken bij arbeidsangeschlkten een verslechtering in objectleve en subjectieve gezondheld met zich meebrengt. De verslechtering van de subjectieve gezondheid wordt mede in de hand gewerkt omdat voor hen "leven zonder werk" problematischer is dan leven met een handicap (Merens-Rledstra, 1981). Dit zal nar wij veronderstellen een negatieve weersilag hebben op hun toch al kwetsbare lichamelljke gezondheld.

Daarnast speelt ook nog een selectie-effect mee. Naarmate de arbeidsongeschiktheid langer duurt, wordt de kans op reintegratie in het 
arbeidsproces geringer. Van de arbeidsongeschikten die het werk hervatten, doet $71 \%$ dit binnen twee jaar na intrede in de arbeidsongeschiktheidswet (Buys, 1984). Het lijkt ons annemelijk dat dit het relatief meer gezonde deel betreft, daar de voornamste redenen tot uittreding pensionering en overlijden zijn, zoals reeds in hoofdstuk 3 geconstateerd is. In ditzelfde hoofdstuk constateerden we ook een selectie-effect onder werklozen. We verwachten dan ook dat onder hen de duur van het niet werken samenhangt met een slechte objectieve en subjectieve gezondheid. De slechte objectieve gezondheld hangt voornamelijk samen met het selectie-effect, terwijl de slechte subjectleve gezondheid vooral een causaal gevolg is van het lang zonder werk zijn (Bartley, 1985; Kruidenier, Bakker, 1985; Warr, 1983; Verkley, Spruit, $1987)$.

Hypothesen gerapporteerde gezondhefd

1 Niet werkenden onderling

1.1 Arbeidsongeschikten zijn intrinsiek ongezonder, dat wi1 zeggen dat zij een slechtere subjectleve en objectieve gezondheid hebben dan werklozen en vervroegd gepensioneerden.

1.2 Werklozen hebben een slechtere subjectieve gezondheid dan vervroegd gepensioneerden, maar komen in objectleve gezondheid met vervroegd gepenstoneerden overeen.

2 Niet werkenden en werkenden

2.1 Arbeldsongeschikten hebben een slechtere subjectieve en objectieve gezondheld dan werkenden.

2.2. Werklozen hebben een slechtere subjectieve gezondheld dan werkenden, maar komen in objectieve gezondheld met werkenden overeen.

2.3 Vervroegd gepensloneerden komen in subjectieve en objectieve gezondheid overeen met werkenden.

3 De duur van het niet werken

3.1 Langdurig werklozen en arbeldsongeschikten hebben een slechtere subjectieve en objectieve gezondheld dan de kortdurig niet werkenden; deze relatie tussen duur van het niet werken en gezondheld doet zich niet voor bij vervroegd gepensioneerden. 
3.2 De duur van het niet werken heeft een negatief effect op de subJectleve en objectleve gezondheid wan arbeidsongeschikten.

3.3 De duur van het niet werken heeft een negatief effect op de subJectieve gezondheld van werklozen; $z 1 j$ heeft geen effect op de objectleve gezondheld.

3.4 De duur van het nlet werken heeft bij verwroegd gepensioneerden geen negatief effect, noch op de subjectleve, noch op de objectieve gezondheld.

Relatle gerapporteerde en objectief vastgestelde gezondheid

Op grond van de in hoofdstuk 3.2 vermelde uitspraken van onderzoekers over de slechte gezondheid, hoge medische consumptie en ongunstige sterfteclffers van arbeldsongeschikten in vergelijking met werklozen mogen we veronderstellen dat de gerapporteerde gezondheld niet afwijkt van de gesignaleerde gezondheid. Gelet op de literatuur warin gezondheidsrapportage betreffende het voorkomen van chronische aandoeningen door buurtbewoners vergeleken wordt met rapportage door huisartsen en wijkverpleegkundigen, mogen we hetzelfde veronderstellen (Van den Bos, Van der Maas, 1987). Bovendien vormt het aordeel over de eigen gezondheld een belangrijke voorspeller van mortaliteit, hetgeen ook een reden is om geen grote verschillen te verwachten tussen gerapporteerde en objectief vastgestelde gezondheid (Kaplan, Camacho, 1983).

Hypothese over relatie vastgestelde en gerapporteerde gezondheid

Zelfrapportage over gezondheld vam nlet werkende en werkende mannen komt overeen met rapportage door huisartsen aan de hand van medische dossters. 
4.4.2. Gezondheidsopvattingen

Belang gezondheid

De gezondheid van arbeidsongeschikten is slecht, nat wij veronderstelden. Daarom zullen zij gezondheld hoger waarderen dan werklozen en vervraegd gepensioneerden. De, veronderstelde, minder goede subjectieve en objectieve gezondheid van de langdurig werklozen en arbeldsongeschikten zal invloed hebben op de wardering van gezondheid (Halfens et al., 1988). Gezondheid wordt, naar wij veronderstellen, door arbeidsongeschikten en werklozen in de loop van de tijd hoger gewardeerd omdat hun gezondheid achterult gat: bij arbeldsongeschikten geldt dit voor de subjectieve en objectleve gezondheid en bij werklozen alleen voor de subjectieve gezondheid. We leiden onze hypothesen mede af van de constatering dat mensen die zich zelf minder gezond of ongezond achten een meer expliciete opvatting over gezondheid hebben dan mensen die zichzelf gezond achten (Currer, Stacey, 1986). Ongezond zifn loopt ons inzlens parallel met het centraal stellen van gezondheid en daarmee een groter belang toebedelen aan gezondheld.

Hypothesen belang van gezondheid

1 Niet werkenden onderling.

1.1 Voor arbeidsongeschikten neemt gezondheid een hogere prioriteit in ten opzichte van andere warden dan voor werklozen en vervroegd gepensioneerden.

1.2 Voor werklozen heeft gezondheid eenzelfde prioriteit ten opzichte wan andere warden als voor vervroegd gepensioneerden.

2 Niet werkenden en werkenden

2.1 Arbeldsongeschikten geven aan gezondheid een hogere prioritelt ten opzichte van andere warden dan werkenden.

2.2 Werklozen en vervroegd gepensioneerden geven aan gezondheid dezelfde prioritelt ten opzichte van andere warden dan werkenden.

3 De duur van het niet werken

3.1 Gezondheld heeft voor langdurig werklozen en arbeidsongeschikten 
een hogere priorltelt ten opzlchte van andere warden dan voor kortdurig niet werkenden. Kort- en langdurig vervroegd gepensioneetden verschllen onderling, nlet in hun prioriteltenstelling van gezondhetd.

3.2 De duur van het niet werken bevordert bif arbeidsongeschikten en werklozen dat gezondheld een hogere priorlteit krijgt ten opzichte van andere warden.

3.3 De duur van het niet werken heeft bij vervroegd gepensioneerden geen invloed op de prioriteitenstelling van gezondheid ten opzichte van andere warden.

Mate warin men meent de elgen gezondheld te kunnen beInvloeden (interne beheersingsoriẻntatie)

Arbeldsongeschikten hebben veelal een lang patiëntencarriere achter de rug, waardoor een sterke, door hulpverleners bevestigde, afhankelijkheid is ontstam. Dit geldt mogelijk ook - zij het in mindere mate voor langdurig werklozen. Dit brengt de opvatting met zich mee de elgen gezondheld minder te kunen beinvloeden (Halfens e.a., 1988). DHt geldt logischerwijs nlet voor werklozen als geheel en evenuin voor vervroegd gepensioneerden en werkenden. De opvatting de gezondheid niet zelf te kunnen beInvloeden, wordt bij arbeidsongeschikten in de loop van de tijd versterkt, omdat, naar wij veronderstellen, chronicitelt als zodanig dit effect oproept; deze chronicitelt brengt een voortdurende consultatie mee van professionele hulpverleners. Langdurige werkloosheid zal in de loop van de tijd vanwege de slechter wordende subjectleve gezondheld ertoe bijdragen dat onder werklozen eveneens de opvatting versterkt wordt niet hun elgen gezondheid te kunnen belnvloeden. De veronderstelde slechtere objectieve en subjectleve gezondheld van langdurig werklozen vergeleken met kortdurig werklozen brengt derhalve een lage fnterne oriëtatie met zich mee.

Hypothesen interne beheersingsorlëntatie inzake gezondheid

1 Nlet werkenden onderling

1.1 Arbeldsongeschikten menen minder dan werklozen en vervroegd gepensioneerden hun elgen gezondheid te kunnen beinvioeden. 
1.2 Werklozen komen wat betreft hun interne beheersingsorientatie inzake gezondheid overeen met vervroegd gepensioneerden.

2. Niet werkenden en werkenden.

2. I Arbeidsongeschikten menen minder dan werkenden hun gezondheld te kunnen beInvloeden.

2.2 Werklozen en vervroegd gepensioneerden verschillen niet van wer kenden in opvatting over de mate warin zil zelf hun gezondheid kunnen beinvlaeden.

3. De duur van het niet werken.

3.1 Langdurig werklozen en arbeldsongeschikten zijn in vergelifking met kortdurig niet werkenden minder van wening dat zij de eigen gezondheid kunnen beInvloeden. Kort- en langdurig vervroegd gepensioneerden verschillen onderling niet.

3.2 De duur van het niet werken belnvloedt de interne beheersingsorlëntatie van arbeidsongeschikten: hoe langer zonder betaalde arbeid, hoe minder men van mening is de eigen gezondheid te kunnen beĩnvloeden.

3.3 De dur van het niet werken heeft wel invloed op de interne beheersingsoriëntatie van werklozen en geen invloed op de interne beheersingsoriëntatie wan vervroegd gepensioneerden.

Mate warin de eigen gezondheid door artsen als machtige anderen belnvioed wordt (externe beheersingsoriëntatie)

In het hiervoor vermelde onderzoek van Halfens komt naar voren dat mensen met een ziekte niet alleen een lagere interne beheersingsorientatie, maar ook een hogere externe beheersingsoriëntatle hebben dan gezonden (Halfens et al., 1988). Dit impliceert dat arbeidsongeschikten vergeleken met werklozen, vervroegd gepensloneerden en werkenden een hogere externe oriëntatie hebben. Bovendien zal - gezien het verloop van de gezondheld - de externe oriëtatie van arbeldsongeschikten op den duur sterker worden. Onder werklozen verwachten we in de loop van de tijd geen hogere score. Eerder veronderstelden we reeds dat de durr van het niet werken invloed heeft op de interne be- 
heereingsorlentatie wan werklozen en nfer op hun externe beheersingsorlentatie. Dit vloelt voort uit de eveneens eerdere onderstelling dat de subjectieve gezondheid van werklozen wel achteruit gat maar de objectieve gezondheld niet, hetgeen niet noadzakelifk een hogere mate van medische afhankelijkheld met zich meebrengt. Niettemin zullen tranbversaal bezlen - langdurig werklozen vergeleken met kortdurig werklozen wel een hogere externe orlëntatie hebben omdat wij onder de langdurlge deelcategorle een slechtere objectieve en subjectieve gezondheld veronderstelden.

Hypothesen exterme beheersingsoriëntatie Inzake gezondheid

1 Niet werkenden onderling

1. 1 Arbeldsongeschikten menen meer dan werklozen en vervroegd gepensloneerden dat machtige anderen hun gezondheid kunnen befnvioeden.

1.2 Werklozen komen in hun externe beheersingsorjëntatie overeen met vervroegd gepensioneerden.

2 Niet werkenden en werkenden

2.1 Arbeldsongeschikten menen meer dan werkenden dat machtige anderen hun gezondheid kunnen beinvloeden.

2.2 Werklozen en vervroegd gepensioneerden verschilien niet in opvatting van werkenden over de mate warin machtige anderen hun gezondheid kunnen beInvioeden.

3 De duur van het niet werken

3.l Langdurig werklozen en arbeidsongeschikten zijn in vergelijking met kortdurig niet werkenden meer van mening dat machtige anderen hun gezondheid kunnen beInvloeden. Kort- en langdurig vervroegd gepenstoneerden verschlllen onderling niet.

3.2 De duur van het niet werken belnvloedt de externe beheersingsorlëntatie van arbeidsongeschikten: hoe langer zonder betaalde arbeld, hoe meer $z i j$ van mening $z 1 j n$ dat machtige anderen hun gezondhefd kunnen beInvloeden.

3.3. De duur van het niet werken heeft geen invloed op de externe beheersingsoriëntatie van werklozen en vervroegd gepensioneerden. 


\subsubsection{Riskante gewoonten}

In de literatuur zijn weinig artikelen te vinden die handelen over de relatie tussen werkstatus en voor de gezondheld riskante gewoonten. Smart (1974) en Warr en Payne (1983) zijn enkele van de weinige auteurs die in hun artikelen op het gebruik van alcoholhoudende dranken en rookgewoonten ingaan. Smart wijdde een artikel aan het gebrulk van alcoholhoudende dranken onder werkenden en niet werkenden. Evenals de twee andere genoemde auteurs (Warr en Payne, 1983) concludeerde Smart dat mensen na ontslag ninder alcoholgebrulk rapporteerden. Smart identificeerde wel respondenten die persoonli jke drankproblemen hadden v6б́r ontslag en bij wie het drankgebruik na ontslag intensiveerde. Westcott rapporteerde in 1985 over een onderzoek in Groot-Brittannlë van 1983. Uit een voorlopige analyse kwam naar voren dat verlies van betalde arbeid het gebrulk van alcoholhoudende dranken en het roken van sigaretten intensiveerde. Warr en Payne signaleerden in vorenvermeld onderzoek een stijging van het aantal sigaretten dat door werklozen na ontslag gerookt werd, maar deze toename gold alleen voor ondervraagden uit de arbeldersklasse en niet voor die ult de middenklasse. Brenner wees in een van zijn macro-studles over de relatie tussen economische ontwikkelingen en gezondheld op de nadelige effecten van economische instabilitelt en recessle op het gebruik van sterk alcoholische dranken en het roken van sigaretten en daarmee op de gezondheid (Brenner, 1985). Voor Nederland stelden Becker en Vink (1984) vast dat arbeidsongeschikten en werklozen minder drinken dan werkenden. Knibbe (1984) constateerde versch1llen in consumptie van alcoholhoudende dranken onder mannen nar gelang de werksituatie (werkzoekend, arbeidsongeschikt, gepensioneerd en werkend). Hij kwam tot de hypothese dat de structurering van het dagelijks leven van invloed is up het gebrulk, zif het dat dit sterker geldt voor Rotterdam dan voor Limburg. In Limburg was er uitsluttend bij werkzoekende mannen sprake van een, vergeleken met werkende mannen, intensief drankgebruik. In Rotterdam gold dat ook voor arbeidsongeschikten en gepensioneerden. Knibbe constateerde voorts dat arbeidsongeschikten bijzonder risico"s lopen wanneer zij in het proces geraken van gangbaar tot problematisch drankgebruik, vanwege het relatief hoge percentage arbeidsongeschikten dat dagelijks slaap- of kalmerende middelen 
gebrulkt. Wat rookgewoonten in Nederland betreft hebben we kunnen constateren dat mannen zonder beroep meer roken dan mannen met beroep (van Reek, 1984). Becker en Vink (1984) kwamen tot overeenkomstige aawijzingen. Ook wat deze riskante gewonten betreffen mogen derhalve samenhangen verondersteld worden met niet werken.

De derde variabele die we onder riskante gewoonte opgenomen hebben is het antbreken van lichaamsbeweging. Uit sociografische studies uit zowel de dertiger, zeventiger als tachtiger jaren kowt naar voren dat werkloosheld een samenhang vertoont met onverschilligheid, verveling, lusteloosheid, ultstelgedrag en loomheid (Fagin, Little, 1984; De Lange, Senhorst, 1985; Fryer, 1987). Het 11jkt ons dan ook aannemelijk dat arbeldsongeschikten en werklozen minder dan werkenden tot regelmatige lichamsbeweging komen. Dit geldt ons inziens niet voor VUT-ers ondat zij vrijwillig met werken gestopt zijn, mede ondat zij een (meer) zinvolle structuur in het dagelijk leven menen te kunnen brenger. Of dit ook geldt voor degenen die vanwege functioneel leeftijdsontslag vór hun $65 \mathrm{e}$ jaar de loopbaan beëindigd hebben, is ons njet bekend; wij veronderstellen van wel, omdat zij jaren van te voren wisten dat $z i j$ op een bepaalde leeftija (bijvoorbeeld 55) met pensioen zouden gaan.

Een niet onbelangrijke vraag is of er een relatie bestaat tussen gezondheid van niet werkenden en riskante gewoonten. Uitkomsten op dit terrein lijken niet met elkaar in overeensteming. Knibbe stelde vast dat geheelonthouders van 40 jaar en ouder een slechtere gezondheid kebben dan niet geheelonthouders. Arbeidsongeschikten echter met een minder posttlef oordeel over de elgen gezondheid bleken zich niet duldelljk $\mathrm{ln}$ drankgebruik te onderscheiden van die met een positiever oordeel. Ondat knlbbe wel een duidelijke samenhang constateerde tussen de structurering van het dagelijks leven, hetgeen primair geindiceerd is in het vertichten van betaalde arbeid, en drankgebruik, zullen we onze hypothese toch vanuit dit gezichtspunt inhoud geven. Mede ondat hij vaststelde dat arbeidsongeschikten ten dele weinig en ten dela veel alcoholhoudende dranken gebruiken, gaan we ervan uit dat $z i j$ mér riskante gewoonten hebben dan werkenden en vervroegd gepensioneerden, maar minder dan werklozen.

Het lijkt ons aannemelijk dat arbeidsongeschikten op den duur meer riskante gewoonten vertonen, evenals werklozen, omdat het gemis van 
arbeid op den dur zwarder weegt dan de chronlsche andoening (Merens-Riedstra, 1981).

Dit proces wordt bij arbeidsongeschikten mogelljk nog versterkt amdat $z i j$, op den duur, van mening zijn dat zij minder hun eigen gezondheld kunnen belnvloeden. Bij vervroegd gepensioneerden verwachten we geen verandering in de loop van de tije omdat zij bij het besluit met werken te stoppen, al een zinvolle alternatieve structuur voor het dagelijks leven uitgestippeld hebben. Conform bovenstaande redenering verwachten we onder langdurig werklozen en arbeidsongeschikten meer riskante gewoonten dan onder kortdurig niet werkenden.

\section{Hypothesen riskante gewoonten}

1 Niet werkenden onderling

1.1 Arbeidsongeschikten vertonen minder riskante gewoonten dan werklozen, maar meer dan vervroegd gepensioneerden.

1.2 Werklozen hebben meer riskante gewoonten dan vervroegd gepensioneerden.

2 Niet werkenden en werkenden

2.1 Arbeidsongeschikten en werklozen hebben meer riskante gewoonten dan werkenden.

2.2 Vervroegd gepensioneerden komen in riskante gewoonten overeen met werkenden.

3 De duur van het niet werken

3.1 Langdurig werklozen en arbeidsongeschlkten hebben in vergelijking met kortdurig niet werkenden meer riskante gewoonten. Lang- en kortdurig vervroegd gepensioneerden verschillen onderling niet.

3.2 De duur van het nlet werken bevordert het ontwlkkelen van riskante gewoonten van arbeldsongeschikten en werklozen.

3.3 De duur van het niet werken heeft geen effect op riskante gewoonten van vervroegd gepensioneerden. 


\subsubsection{Participatie}

Verlles van betalde arbeid brengt met zlch mee dat de meeste contacten die men wia het werk onderhield op den duur verbroken worden. Het zouden vooral deze contacten $z i j n$ die verantwoordelijk zijn voor het kleinere aantal contacten na het werkloos worden (Sprengers, Tazelaar, 1987). Werklozen blifken gemiddeld in lichte mate eenzamer dan werkenden. Deze eenzaamheld, die in leder geval niet zou gelden voor 40\% van de werklozen, wordt mede in de hand gewerkt door het gerilnge aantal contacten ên de kwalitelt ervan (Sprult, Verkley, De Jong-Gierveld, Steverink, 1987).

Uit een ander onderzoek komt naar voren dat werklozen en arbeidsongeschikten weliswaar meer dan werkenden aan vrijwil11gerswerk en hobby"s doen, maar minder vaak lid zijn van verenigingen (Becker, Vink, 1984). Belangstelling voor de politiek lijkt onder nlet werkenden kleiner dan onder werkenden, terwij1 arbeidsongeschikten vergeleken met werklozen meer politieke belangstelling hebben (Becker, Vink, 1984). Specifieke vergelfjkingen Inzake participatie tussen niet werkenden onderilng ontbreken. We nemen aan dat arbeldsongeschikten, vanwege de legitimatle van hun nlet werkende status door de ziekte, meer soclale contacten hebben dan werklozen, maar minder dan werkenden. Dit zal mogelijk mede in de hand gewerkt worden door het bestaan van belangenverenigingen van en voor arbeldsongeschikten; dergelijke verenigingen bestaan voor zover wij weten niet voor werklazen.

Tevens onderstellen 1 dat vervroegd gepensioneerden niet van werkenden verschillen, ondat zij, zoals eerder aangegeven, een alternatieve structuur voor het dagel1jk leven voor ogen hebben, eveneens een gelegitimeerde status van niet werken hebben $e_{n}$ omdat in hun leeftijdscategorle een groter deel van de mannen niet werkt. Daamee is de kans op contacten met leeftijdsgenoten groter dan wanneer het merendeel zou werken. We nemen aan dat de duur van het niet werken bij werklozen en arbeidsongeschikten bijdraagt tot een kleiner netwerk en tot een kleiner aantal contacten. Dit kleiner aantal contacten wordt mede in de hand gewerkt doordat degenen met veel "lossere" contacten via verenigingen en clubs grotere kans zouden hebben betaalde arbeid te vinden (Sprengers, Tazelaar, 1987). 
Hypothesen participatie

1 Niet werkenden onderling

1.1 Onder arbeidsongeschikten is in vergelijking wet werklozen sprake van een grotere mate van participatie; in vergelijking met vervroegd gepensioneerden is sprake van mindere particlpatie.

1.2 Onder werklozen vinden we een lagere participatiegraad dan onder vervroegd gepensioneerden.

2 Niet werkenden en werkenden

2.1 Arbeldsongeschikten en werklozen vertonen een lagere participatiegraad dan werkenden.

2.2 Vervroegd gepensioneerden hebben eenzelfde participatiegraad als werkenden.

3 De duur van het niet werken

3.1 Onder langdurig werklozen en arbeidsongeschikten is, in vergelijking met kortdurig niet werkenden de participatiegraad lager. Kort- en langdurig vervroegd gepensloneerden verschillen niet van elkaar.

3.2 De duur van het niet werken bewerkstelligt een afnemende mate van participatie onder arbeidsongeschlkten en werklozen.

3.3 De duur van het niet werken heeft geen invloed op de mate van participatie van vervroegd gepensioneerden.

\subsection{Operationallsatie}

\subsubsection{Gezondheid}

Omdat, zoals in paragraaf 4.3 aangegeven, gezondheld vastgesteld wordt onder een landelijke steekproef ult de bevolking (gerapporteerde objectleve en subjectieve gezondheld) en onder praktijkpopulatles (vastgestelde objectleve gezondheld) zullen we twee operationalisaties geven van de variabele gezondheid, namelijk Een met betrekking tot de gerapporteerde en één met betrekking tot de vastgestelde gezondheid. 


\subsubsection{De landel1jke steekproef}

In de landelijke steekproef werden zes maten voor gezondheld opgenomen:

1 de an- of afwealgheld van een chronische/langdurige aandoening, waarvoor men regelmatig onder controle is;

2 het aantal malen dat men gedurende het afgelopen jaar contacten heeft gehad met een behandelend arts;

3 de score op de voEG-11jst (Vragenlijst onderzoek Ervaren Gezondheid). In 1981 is de verkorte versie, bestaande uit 21 vragen, gebrulkt. In $19831 \mathrm{~s}$ een lange versle voorgelegd van 40 vragen (Van Reek et 1., 1983; Joosten, Drop, 1987);

4 het aantal medicifnen dat men gedurende een maand op eigen initiatief genomen heeft;

5 beoordeling van de eigen gezondheid aan de hand van een viffpuntschal, variërend van zeer goed (5) tot zeer slecht (1);

6 zorgen maken over de eigen gezondheld eveneens aan de hand van een vijfpuntschaal, variërend van noolt (5) tot zeer vaak (1).

De vijfde maat houdt een algemene zelf-beoordeling in van de eigen gezondheid. De beoordeling van de elgen gezondheld kan beschouwd worden als een voorspeller van morbiditeit en mortaliteit (Kaplan, Camacho, 1984). Tezamen met de vOEG-score en het medicijngebruik verwijzen deze vragen vooral naar de beleving van de gezondheid. Om deze reden betitelen we deze als een cluster betreffende de gerapporteerde subjectleve gezondheld. De eerste twee maten hebben een meer objectlef karakter, hetgeen we tot uftdrukking hebben laten komen in de term "gerapporteerde objectieve gezondheid".

\subsubsection{Prakt 1 kpopulatie onderzoek}

In de hulsartspraktijk hebben de artsen 1 in 1987 per patiënt de volgende gegevens vastgelegd:

1 de probleemlljst; op deze lifst wordt een opsoming gegeven van vier typen problemen, namelifk medisch-lichamelijke en psychosociale problemen, alsmede problemen in de arts-patiënt relatie (bijvoorbeeld somatische fixatie) en overige problemen (bijvoorbeeld risicopatient, gebrulk genotmiddelen); 
2 het aantal contacten met de patiënt in 1986 .

De door de huisarts relevant geachte problemen werden geclassificeerd aan de hand van het ICPC-systeem (International Classification of Primary Care), dat ontwikkeld is vanult het RFE-systeem (Reason for Encounter) (Lamberts, Wood, 1987; Meljer et a1., 1987).

In het kader van het ontwikkelen van een registratienetwerk voor huisartsen 1 s de $\mathbb{I C P C}$ in de praktijk geintroduceerd, mede ten behoeve van dit onderzoek. De opbouw van de ICPC geven we weer in de hiernavolgende figuur, die we in het kort bespreken.

Figuur 3 apbouw van de ICPC.

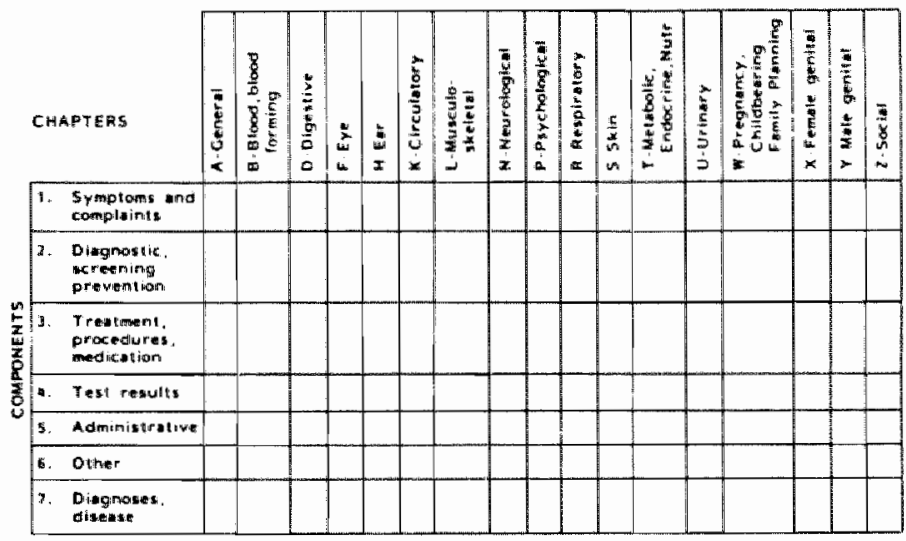

Bron: Lamberts en Wood, 1987

De structuur van de ICPC berust op twee assen met als een as de 17 horizontaal afgedrukte hoofdstukken en als andere as de 7 vertical afgedrukte componenten. Voor ons $z 1 j n$ alleen relevant de 17 hoofdstukken, met uitzondering van de hoofdstukken $W$ en $X$ omdat deze slechts relevant zijn bij vrouwen, en de componenten 1 (symptomen en klachten) en 7 (diagnosen en ziekten). Er is gekozen voor een alfanumerieke codering met drie symbolen. Het eerste symbool verwljst naar het hoofdstuk (bijwoorbeeld $\mathrm{Skin}=\mathrm{S}$ ). De twee volgende symbolen (b1jvoorbeeld 29) verwijzen naar de component. De componenten zljn steeds op dezelfde wijze gerangschikt: de codes 1 t/m 29 voor klachten en symptomen, $30 \mathrm{t} / \mathrm{m} 69$ voor de vijf verschillende componenten $(2 \mathrm{t} / \mathrm{m} 6)$ die naar verrichtingen verwijzen en $70 \mathrm{t} / \mathrm{m} 99$ voor de diagnosen (ontleend aan 
Meyer et a1, 1987). In 1980 1s de RFE-C in Nederlandse hulsartspraktijken getest. Later is een 1nternationale studie naar de praktische haalbaarheid gedaan in negen landen. De classiflcatie blijkt "goed hanteerbaar en adquat" ook als de huisarts zelf tijdens het spreekuur codeert (Van der Horst et al., 1985). Niet alle hulsartsen hebben in hun patiëntosslers naast de gebrulkelljke verslaglegging een aparte probleeml1jst. De verslaglegging is een logboek van arts-patlënt contacten; de probleemlljat een daarult geabstraheerde opsoming van (relevante) problemen die in de consultaties aan de orde zijn (geweest). Voor het praktijkpopulatie-onderzoek is een computerprograma ontwikkeld ten behoeve van de ICPC probleeml1jst (Dupults et al, 1986, 1987). Om vast te stellen of een probleem een actlef (A) of inactief (I) karkater heeft, is ten behoeve hiervan de mogelijkheid geboden de code A of I toe te voegen. In hoofdstuk 9 wordt de betekenis hierwan nader uitgelegd.

\subsubsection{Gezondheidsopvattingen}

4.5.2.1 Gezondheldsopvattingen: belang van gezondheid

Het belang van gezondheid wordt vastgesteld door aan de respondenten negen waarden voor te leggen en hen te vragen welke daarvan belangrijker, even belangrijk of minder belangrijk zijn dan gezondheid. Deze waarden zijn: gezin, vrijheid, vriendschap, huisvesting, werk, sociale zekerheid, geloof, sport en geld.

4.5.2.2 Gezondheldsopvattingen: mate warin men de elgen gezondheld kan beInvloeden.

Deze opvatting wordt gemeten met behulp van een serie vragen waarmee langa drie onafhankelijke dimensies kan worden vastgesteld in hoeverre men meent de gezondheld zelf te kunnen beinvloeden (interne beheerslingsoriëntatle), In hoeverre artsen als "machtige anderen" dit kunnen, en in hoeverre dit afhankelijk is van kans of toeval (Halfens, 1985). Onze hypothesen hebben alleen betrekking op de interne en de 
externe beheersingsoriëntatie, omdat over de kansorientatie van niet werkenden voor zover wif weten geen literatur beschikbar is.

\subsubsection{Riskante gewoonten}

Als riskante gewoonten zijn drie specifieke gedragsaspecten in de analyse betrokken, namelijk het roken van sigaretten, gebruik van alcoholische dranken en gebrek aan lichaamsbeweging. Het gaat niet alleen om de vraag of, maar ook in welke mate hiervan sprake $i s$. Daarnaast hebben we ook de vraag naar de beoordeling van de ellgen leefwijze in ons onderzoek opgenomen, tenelnde vast te stellen of riskante gewoonten samenhang vertonen met de beoordelfng van de eigen leefwiljze.

\subsubsection{Participatie}

Particlpatie wordt vastgesteld aan de hand van de volgende vijf aspecten:

1 contacten met wrienden/kennissen;

2 contacten met familie;

3 contacten met (ex-) collega's;

4 lidmaatschap van verenigingen of clubs. Wanneer men aangaf hiervan lid te zijn, werd vastgesteld hoeveel de tijdsbesteding in uren per week is;

5 stemgedrag bij de laatste landelijke verkiezingen. Gevraagd werd of men gestemd heeft (wel of niet);

6 lidmatschap van kerkgenootschap, sekte of andere organisatie van levensbeschouwelijke grondslag (wel of geen lid).

\subsection{Samenvatting}

In dit hoofdstuk $z i j n$ we begonnen met een aantal overweglingen die richting geven aan het onderzoek. Deze overwegingen berusten mede op de resultaten van het literaturroverzicht van hoofdstuk 3 . 
Vervolgens hebben we in paragraaf 4.3 de probleemstelling omschreven en de daarin gebrulkte begrippen nader ultgewerkt.

De hypothesen z1jn in paragraaf 4.4 vastgelegd. Alvorens de hypothesen weer te geven hebben we eerst op basis van geraadpleegde 1iteratuur ter aanvulling op hoofdstuk 3 de relevante bevindingen beschreven. Tot lot komt in paragraaf 4.5 de operationalisatle aan de orde. 


\section{Methoden en Populaties}

\subsection{Inleiding}

Het onderzoek omvat wat betreft de relatie cussen niet werken en gezondheid twee afzonderlijke delen, namelijk een panelonderzoek en een onderzoek in enkele huisartspraktijken. In dit hoofdstuk zullen beide onderzoeken afzonderlijk besproken worden.

In paragraaf 5.2 komen de onderzoeksmethoden aan de orde, in paragraaf 5.3 de populaties en in paragraaf 5.4 de gebruikte statistische methoden.

\subsection{Methoden van onderzoek}

\subsubsection{Het panelonderzoek}

De redenen om de probleemstelling te onderzoeken op bas is van het Nederland Oke materiaal hebben we in het vorige hoofdstuk gegeven. In deze paragraaf zullen we de in betreffend onderzoek gevolgde methode in het kort verantwoorden.

In het kader van een actie ter bevordering wan een gezonde leefwijze kreeg de $\mathbb{R i j k s u n i v e r s i t e i t ~ L H m b u r g ~ w a n ~ d e ~ S t i c h t i n g ~ N e d e r l a n d ~ o k e ~ d e ~}$ opdracht een landelijk onderzoek te doen naar de gezondheld, gezondhefdsopvattingen en leefwljze van de Nederlandse bevolking. Dit onderzoek is uftgevoerd in 1981. In augustus 1981 is hierover gerapporteerd (Adriaanse et a1., 1981). In 1982 is besloten de onderzochte populatie als panel te vervolgen. Dit kreeg in 1983 zijn beslag. Het onderzoek van 1981 werd daarbij als eerste meting beschouwd, dat van 1983 als tweede. De survey van 1983 betrof een herhalde meting bij dezelfde personen, en bevatte tevens dezelfde variabelen. De rapportage van het. 
tweede deel vond plaats in 1984 (Halfens et a1., 1984). In het Nederland oke onderzoek $21 j n$ vier populaties onderscheiden waaruit steekproeven werden getrokken: de algemene bevolking tussen 21 en 65 jaar (1), de niet werkenden in dezelfde leeftijdscategorie (2), onderwijzend personeel (3) en professionele gezondheldszorgwerkers, te weten praktiserende huliartsen, wjkverpleegkundigen en maatschappelijk werkenden (4).

De gegevene werden verzameld met behulp van een gestructureerde vragenlijst, die werd ontwkkeld door medewerkers van de universiteit. De interviews werden uitgevoerd door een extern onderzoeksbureau. Dit gebeurde door interviewers die daartoe een speclale training gekregen hadden. Alle respondenten $z$ jjn thuis bezocht. Ter compensatie van de te verwachten panel-uitval is aan de tweede meting in 1983 een nieuwe steekproef toegevoegd. In paragraaf 5.3 geven we een verantwoording hiervan.

De steekproeven $z 1 j n$ op getrapte en a-selecte wijze getrokken.

- Eerst werden de gemeenten getrokken. Daarbij werd uitgegaan van het aantal inwoners dat in een provincle verdeeld is naar urbanisatiegraad. De inwonertallen per gemeente berusten op een CBS telling (CBS, 1982 ).

- Vervolgens werden per gemeente evenveel postcades getrokken als er gesprekken gerealiseerd moesten worden. Het verkregen aantal adressen werd vervolgens gedeeld door het aantal te ondervragen adressen, wardoor een trekkingsinterval woor de selectie van adressen ontstond. Elk $\mathrm{n}^{\text {de }}$ adres werd aldus geselecteerd uit het totaal der adressen.

- De derde stap betrof de selectie der personen volgens het principe der richtgetallen. Een te interviewen persoon moest in leder geval voldoen aan de gestelde steekproefcriteria: tussen 21 en 65 jaar én 4 dagen of meer per week deel uitmaken van het huishouden. Deze procedure gold zowel voor de steekproef van de totale bevolking als voor de ateekproef van nlet werkenden.

Voor de steekproef niet werkenden golden bovendien nog enkele aanvullende criterla. Met behulp van de geselecteerde startadressen is de "random-walkmethode" toegepast. Dit houdt in dat de interviewer lopend vanuit het startadres, net zolang doorgat met de eerste, tweede, enz. 
deur eerst links en dan rechts te nemen, tot een bewoner gevonden wordt die voldoet aan ét van de volgende criteria:

- 6 maanden of langer werkloos

- 3 maanden of langer ziek

- gepensioneerd vór het $65^{\mathrm{e}}$ levensjaar

- arbeidsongeschikt (WAO/AAW).

Bleek bij de bevolkingssteekproef iemand niet thuis $z 1 j n$, dan werd maximaal twee keer een nieuw bezoek gebracht, zowel op een andere dag als op een ander tijdstip. Voor de steekproef niet werkenden is door middel van "oversampling" getracht het als doel gesteld netto atatal gesprekken te realiseren, omdat een grote non-response verwacht werd (Research \& Marketing, 1981). In totaal dienden uit de eerste steekproef 200 respondenten en uit de tweede steekproef 250 respondenten geInterviewd te worden.

De hoofdonderwerpen van het onderzoek waren: gezondheid, gezondheidsopvattingen en leefwijze (roken, gebruik alcoholische dranken, geneesmiddelen gebrulk, lichaamsbeweging, voeding en velligheid). De meeste vragen van 1981 werden in 1983 herhaald.

De in de volgende hoofdstukken beschreven resultaten berusten, met uitzondering van hoofdstuk 9, op analyse van het materiaal uit de hierboven genoemde panelstudie.

\section{2 .2 Het praktijkpopulatie-onderzoek}

Dit onderzoek heeft betrekking op de praktijkpopulatie van vijf hulsartsen, afkomstig uit én geacademiseerd gezondheidscentrum. De totale populatie onvatte per $\mathbb{1}$ januar 1987 clrca 10.000 patiënten; $60 \%$ ervan behoorde tot de zlekenfondspatiëntenpopulatie en $31 \%$ tot de particuliere patiëntenpopulatie. Half mart 1987 werd aan alle mannen tussen 21 en 64 jaar een brlef gestuurd, ondertekend door de Rijksuniversiteft Limburg en de hulsartsen van het centrum. In deze brief werd. in algemene termen, dat wl zeggen zonder specifiek te verwijzen naar dit onderzoek, verzocht om een bijgevoegd enqueteformulier in te vullen en in de eveneens bijgevoegde portvrije enveloppe terug te sturen. Het enquêteformulier bestond uit een $A-$ en een B-deel. Het 
A-deel van het patientenfarmiler werd gebruikt om de patiëntenadministratle ar te wullea, het $\mathbb{B}$-deel was bestemd voor wetenschappelijk onderzoek. De hulsartaen en de RL, ondersteund door een reglsterreglement, garandeerden de anonimiteit. Daarenboven werd besloten dat, ow te beglnnen met het in kaart brengen van alle patienten, een eerste ronde gemakt zow worden onder de mannen van 21-65 jaar.

Na twee weken (1 nmidels had $43 \%$ van de aangeschreven patiënten geantwoord) werd een herinneringsbrief verstuurd, hetgeen resulteerde in een extra respons van $21 \%$. Van een tweede herinnering werd afgezlen ondat de hufsartsen vreesden dat deze teveel druk op de patienten zou leggen.

De vragen hadden betrakking op de achtergrondwariabelen. Het A-deel omvatte: geslacht, leeftijd, burgerlijke staat en verzekeringsvorm; het B-deel: woonverband, sociaal-economische klasse op basis van (vroeger) beroep en opleiding.

Tevens werden im het B-deel vragen gesteld over de werksituatie, op het moment van het invulien van het formulier (1987), alsmede de werksituatle in 1985 en 1986. Wat betreft werksituatie werd ook verwezen naar verschillende vormen van niet werken: studerend, militaire dienst, werkloosheld, arbeidsongeschiktheid, vervroegde uittreding, functioneel leeftijdsontslag en pensioen. Daarnaast werd gevraagd of In 1985, 1986, dan wel in 1987 het gevaar bestond de baan te verliezen In verband met collectlef ontslag en/of reorganisatie.

Alle pattëntengegevens zljn door de praktijkassistentes op een nieuw ontwlkkeld Hulsarts Informatie en Onderzoekssysteem (HIOS) ingevoerd, nadat de formulieren gescreend waren op volledigheid, duidelijkheid en consistentie. Het HIOS stat beschreven in artikelen van Dupults et al (1986, 1987). Een gedeelte van de formulieren is pas ingevoerd nadat de arts of assistente over de ontbrekende of anduidelijke gegevens met de betreffende patient telefonisch contact opgenomen had. In sommige gevallen kon de arts zelf de aanvullende gegevens leveren.

Bif de start van het onderzoek werd verwacht, op basis van het geschatte percentage werklozen, arbeidsongeschikten en vervroegd gepensioneerden In Noord Limburg, dat er circa 400 mannelijke niet werkenden in de praktijk aanwezig zouden zijn. Van de gevonden niet werkenden en werkenden hebben de huisartsen probleemlijsten gemaakt, overeenkomstig de opzet van de probleemgeoriënteerde verslaglegging ( $z i e$ 
hoofdstuk 4). Deze lifsten werden door de betreffende huisartsen samengesteld, zonder dat zij op basis van dit onderzoek geInformeerd waren over wie wel en wie niet werkten. Hiermee wilden we een eventuele vooringenomenheid bij het opstellen van de lijsten voorkomen. viteraard waren een aantal patiënten blj hen bekend als niet werkend, maar men kon aan de hand van de groene NHG patiëntenkaart geen verantwoord systematisch overzicht maken. Het al dan niet verrichten van betaalde arbeid werd blijkbaar niet beschouwd als een relevant achtergrondgegewen voor de hulpverlening en praktijkvoering.

Afgesproken werd om aan de hand wan de groene NHG-patientenkaarten zoveel mogelijk in de tijd terug te gaan, en per gesignaleerd probleem aan te geven in hoeverre dit op het moment van het opwaken van de probleemlijst een actief of inactief karakter had.

Een probleem heeft een actief karakter wanneer dit naar het oordeel van de huisarts een min of meer gezondheidsbedreigend ristco inhoudt, dan wel voor de patient dusdanige hinder oplevert in het dagelifks leven dat het probleem voortdurend aandacht van de huisarts behoeft. De formele omschrijving van een "probleem" luidt: datgene warvoor door werkers in de gezondheldszorg nadere aandacht, onderzoek of handelen nodig is, omdat het lichamelijk of geestelijk welzijn van de patiënt verminderd kan worden of reeds verminderd is (Sandlow 1978; geciteerd in: Metsemakers en Plagge, 1987). Sandlow heeft een grove indeling naar typen problemen gemaakt, overeenkomstig het vermelde in paragraaf 4.5.1.2. Een probleem is actief in de operationele betekents wanneer het langdurig onder de aandacht van de hulsarts of de patient staat, hetgeen blijkt wit:

- speciaal dieet, medicatie of specifieke therapie

- (verder) onderzoek waarmee arts/patiënt nog bezlg blijft

- progressief verloop ervan

- regelmatige controle ervan door de huisarts.

Een probleem wordt geacht inactief te zijn op het moment dat de hulsarts constateert dat het, al dan niet voorlopig, opgelost 1s (bifvoorbeeld relatieproblemen, hypertensle) dan wel geen speciale aandacht meer behoeft (geslaagde hartoperatie, operatleve verwijdering van aambelen). Om te voorkomen dat het geheel aan de aandacht ontsnapt blijft het op de probleemlijst staan met de aantekening. "Inactief", aangevuld met de datum warop dit geconstateerd is. 
Omat de opvattingen wan de hulsartsen over de vraag wanneer er sprake is van een (actlef) probleem, onderling kunnen verschillen, hebben wij binnen de populatie van elke hulsarts afzonderlijk niet werkenden met werkenden gematcht, op basis van eerdergenoemde achtergrondkenmerken. Als de arts nlet wist of op de pelldatum een eerder gesignaleerd probleem een actlef dan wel een Inactief karakter had, werd hlj/zij geacht een vraagteken te platsen.

Aanvankelijk hebben de hulsartsen de problemen genoteerd op de groene kaart. Daarna heeft dezelfde arts de problemen ingevuld op een formulier dat voor computerinvoer geschikt was (Dupuits et al., 1987). Later hebben de hulsartsen alle problemen rechtstreeks ingevoerd. Z1j hebben elk probleem een ICPC-code (International Classification of Primary Care) gegeven. Met een speciaal daartoe ontwikkeld programa werd bevorderd dat de toedeling van de code op betrouwbare wijze gebeurde. Voor een verantwoording van de betrouwbarheid van het RFE-deel van de ICPC-1ijst en een beschrijving wan de ICPC verwijzen we respectlevel1 jk naar Van der Horst et al. (1985) én Lamberts (1987) en Meyer et al. (1987).

Naast de probleemlljst 1 s van alle patiënten die de enquête beantwoordden het aantal contacten met de hulsarts over 1986 en (een gedeelte van) 1987 vastgelegd. Daartoe werd een code van de ICPC gereserveerd, dle voor de probleemlijst nlet van toepassing was. Over de betrouwbarheld van het aantal vastgelegde contacten kunnen we alleen vermelden dat de huisartsen ons verzekerd hebben dat alle contacten vastgelegd zifn en worden.

De resultaten van dit praktifkonderzoek komen in hoofdstuk 9 aan de orde.

\subsection{De populaties}

In de eerste deelparagraaf bespreken we in het kort de steekproeven ult de Nederlandse bevolking van 1981 en 1983 en de steekproeven uit de niet werkende bevolking. In de tweede deelparagraaf bespreken we de praktijkpopulatie. 


\subsubsection{Het panelonderzoek}

\subsubsection{Totale bevolking}

In 1981 zijn 1278 respondenten (response: $73 \%$ ) uit de getrokken steekproef geinterviewd; in 19831193 respondenten. Conform de opdracht een panelonderzoek uit te voeren, zijn in 1983 de 1278 respondenten wit 1981 opnieuw benaderd. Om eem veelvoud van redenen (in volgorde van belangrijkheid voornamel1 jk "weigering" en "niet thuis") heeft $31 \%$ niet aan het tweede interview deelgenomen, hetgeen inhoudt dat $69 \%$ van de respondenten uit 1981 twee achtereenvolgende malen aan het onderzoek meegewerkt heeft. De aanvullende populatie in 1983 omvatte 311 respondenten (response 58\%), waarmee de steekproef uit 1983 op $\$ 193$ respondenten kwam (Adriaanse et al., 1981; Halfens et al., 1981; Halfens, 1985$)$.

De representativitelt van de steekproef uit 1981 is ten aanzien van een aantal kenmerken gecontroleerd door middel van vergelijking met een normpopulatie van het National Onderzoek Persmedia (NOP), waarin alle personen van 2l-64 jaar, levend in huishoudingen opgenomen zijn. Ten aanzien van provincie, urbanisatiegraad, opleiding en sociale klasse zijn er geen opvallende verschillen tussen de steekproef Nederland oké $(n=1278)$ en genoemde normpopulatie $(n=75.247)$. Voor verdere verantwoording hieromtrent verwijzen we naar Halfens et al. (1984) en Halfens (1985).

\section{3 .1 .2 Niet werkenden}

In 1981 zijn met 247 niet werkenden (mannen en vrouwen) gesllagde interviews gehouden (response: $76 \%$ ); in 1983 betrof het 253 respondenten. Deze cijfers waren conform de opdracht aan het onderzoeksbureau, namelijk in beide fasen respectlevelijk 200 en 250 interviews te houden. Van de 247 in 1981 geinterviewden zijn 153 respondenten in 1983 voor een tweede keer ondervraagd. Van de 94 ultvallers welgerden er $48(51 \%)$; de overige $46(49 \%)$ bleken om ulteenlopende redenen nlet geinterviewd te kunnen worden. Voor de meesten yan hen (28) bleek de reden ziekte of overlijden; voor de overigen gold dat zlj niet bereik- 
bat waren varwege verhuling, foutlef adres etc. Respondenten die in 1983 weer an het werk waren, zijn niet van het onderzok ultgesloten. Er was een relatief groot aantal uitvallers wegens ziekte of overliden (28 van 247 ) In vergelfjking met het aantal in de totale bevolkingssteekprofe (22 van 1278).

We vervolgen nu met een nadere beschrijving van de populatie niet werkenden en letten daarblj op de oorzakk van het niet werken én op de achtergrondvarlabelen.

We beperken ons nu tot mannen. De steekproef van 247 niet werkenden bestond wor $90 \%$ wit mannen. Daarmee wijkt deze wat betreft de samenstelling narar geslacht aanzienlijk af van de algemene bevolking.

In de 11teratuur zijn alleen gegevens beschikbaar over werkiozen en arbeidsongeschikten: de verhouding werkloze mannen en vrouwen in 1981 was $3: 1$, de verhouding onder de arbeldsongeschikten $2,5: 1$. In 1983 bleef voor de werklozen de verhouding ongeveer gelijk, texwijl die van de arbeldsongeschikten in de richting van $3: 1$ verschoof. Een sluitende verklaring voor de ondervertegenwoordiging van vrouwen kunnen we niet geven. We nemen aan dat vrouwen minder geneigd waren hun identiteit van 'geen betaalde arbeld verrichtend' keabaar te maken, wellicht ondat het niet betald werken in hun leven een minder centrale plaats inneemt dan bij mannen. Dit laatste lijkt aannemelijk gezien het feit dat vrouwen, vergeleken met mannen, meer tijd (moeten) besteden aan andere rollen: huisvrouw, moeder en echtgenote. Zoals in hoofdstuk 4 a1 vermeld ontneemt het nagenoeg ontbreken wan vrowwen ons de moge11 jkheid nader onderzoek te verrichten nas de effecten wan niet werken onder vrouwen. Dit valt te betreuren, omdat wetenschappelijk verantwoorde informatie over vrouwen die ongew1d geen betalde arbeld kunnen verrichten, nagenoeg ontbreekt. In 1983 lag het aantal niet werkende vrouwen lets hoger dan in 1981 , name $11 \mathrm{k} 13 \%$.

Om de categorle mannelifke niet werkenden zo groot mogelijk te maken, althans groter dan het aantal van 222 (90\% van 247) hebben we de niet werkende mannen ult de bevolkingssteekproef toegevoegd an onze steekproef niet werkenden. EÉn categorie niet werkende mannen hebben we buiten de populatie gelaten, namelijk degenen die rapporteerden arbeldsongeschikt te z1jn omdat ze op het moment van het interview drie maanden of langer zlek thuis waren, doch (nog) geen WAO/AAw uitkering 
of ABP-invaliditeitspensioen genoten. Gelet op onze vragstelling leek het ons niet juist deze categorie als arbeidsongeschikt op te nemen, temeer omdat van degenen die drie maanden in de ziektewet lopen twee derde (nog) niet in de WAO/AAW terecht komt (Groothof 1981, Luyckx 1982, Kruidenier 1982: in Buys, 1984).

De "steekproeven" niet werkende mannen zien er voor 1981 en 1983 afzonderlitjk en voor het panel 1981/1983, als volgt uit (tabe1 5.1):

Tabel 5.1 Aantallen niet werkende mannen voor 1981 en 1983 afzonderIijk en voor het panel 1981/1983, gedifferentieerd naar oorzaak van het nlet werken.

1981

49

179

46

Arbeidsongeschikten

Vervroegd gepensioneerden

Totaal

274
1983

89

155

49

293
$1981 / 1983$

(2x gein-

terviewd)

In dit onderzoek zijn arbeidsongeschikten enigszins over- en werklozen enigszins ondervertegenwoordigd. Arbeidsongeschikten zijn sterker wertegenwoordigd omdat $z 1 j$ vergeleken met werklozen vaker thuis (bereikbaar) zijn; mogelijk vloeit dit voort uit hun hogere leeftijd, hun gezondheidstoestand en het relatief hoge aantal gehuwden. Daarenboven waren jongeren ( $15-19$ jaar) van het onderzoek ultgesloten.

Hoewel over vervroegd gepensioneerden geen precieze landelijke cijfers bekend $z 1 j n$, mogen we veronderstellen dat ze in onze steekproef verhoudingsgewijs royaal vertegenwoordigd zijn. Deze veronderstelling berust op de 1 in hoofdstuk 2 vermelde cijfers inzake de categorleér. Het aantal arbeldsongeschikte en werkloze mannen is circa vijf keer zo hoog als het aantal vervroegd gepensioneerde mannen. In onze steekproeven zijn er verhoudingsgewijs aanzienlijk meer vervroegd bepensloneerden. Het is niet bekend welk gedeelte van de vervroegd gepensioneerden gebruik gemakt heeft van een vervroegde uittredingsregeling en welk gedeelte om andere redenen v66r de 65-jarige leeftijd gepensioneerd is.

Van de twee keer geinterviewden is het aantal arbieidsongeschikten het 
grootst, gevolgd door respectievell jk verwroegd gepensioneerden en werklazen. Dit wordt wede veroorzaakt door het feit dat arbeidsongeschlkt en verwroegd gepensioneerd zijn een duurzamer karakter heeft. dan werkloos $z 1 j n$, vanwege de beschikbarheid van de laatste categorie voor de arbeldsmarke.

Tabel 5.2 geeft een overzlcht van de mutaties in het aantal respondenten tussen 1981 en 1983. W1t de oorspronkelijke populatle (274) is ex een ultval van bijna de helft: 129, waarvan 25 vanwege het vinden van werk en 104 om andere redenen. Het percentage hervatters is het hoogst onder de werklozen (12 van de 49: $24 \%$ ); van de arbeldsongeschikten heeft $6 \%$ (11 van de 179), en van de verwroegd gepensioneerden $4 \%$ ( 2 van de 46) weer werk gevonden. De werkherwatcers zijn wél geinterviewd, mar toegevoegd aan de algemene bevolkingssteekproef en verwijderd wit die van de niet werkenden.

Tabe1 5.2 Overzicht mutaties niet werkende populatie $1981 \rightarrow 1983$.

$\begin{array}{lll}\text { werklozen } & \text { arbeidson- } & \text { vervroegd } \\ \text { geschikten } & \text { gepensioneerden } & \end{array}$

Populatie 1981

49

179

46

274

uitval na 81 :

- werk gevonden

- andere redenen

$$
-12
$$

$-11$

$-71$

$-2$

$-25$

$-16$

97

27

$-104$

Populate 81-83

21

$+11$

$+57$

$+18$

$+40$

$+14$

$+8$

$+43$

- neuwe populatie

89

155

49

293

Na 1981 zijn 43 mensen, die In 1981 werkten, tot de categorie niet werkenden toegetreden ( 11 via de WW, 18 via de WAO/AAW en 14 via verwroegde penstonering). Tevens zien we dat 105 mannen als niet werkenden voor het eerst in de steekproef niet werkenden of in de bevolkingssteekproef opgenomen zijn.

"Andere redenen" voor uitual zijn onder meer zlekte en overlijden. 
Tabel 5.3 Percentage uitval tussen 1981 en 1983 van geInterviewde populatie wegens ziekte en overlijden.

\begin{tabular}{|c|c|c|c|c|c|c|}
\hline & \multicolumn{2}{|c|}{ werklozen } & \multicolumn{2}{|c|}{$\begin{array}{l}\text { arbelison- } \\
\text { geschikten }\end{array}$} & \multicolumn{2}{|c|}{$\begin{array}{c}\text { vervroegd } \\
\text { gepensioneerden }\end{array}$} \\
\hline & abs. & $\%$ & abs. & $\%$ & abs. & $\Psi_{0}$ \\
\hline populatie 1981 & 49 & & 179 & & 46 & \\
\hline $\begin{array}{l}\text { ultval wegens } \\
\text { - zlekte } \\
\text { - overlijden }\end{array}$ & - & 2 & $\begin{array}{r}9 \\
15\end{array}$ & $\begin{array}{l}5,1 \\
8,3\end{array}$ & $\begin{array}{l}5 \\
3\end{array}$ & $\begin{array}{r}10,8 \\
6,5\end{array}$ \\
\hline Totaal & & 2 & & 13,4 & & 17,3 \\
\hline
\end{tabular}

Vamwege overlijden is de uitval het grootst onder arbeidsongeschikten en het kleinst onder werklozen; veruroegd gepensioneerden nemen een tussenpositie in die dichter bij arbeidsongeschikten dan bij werklozen ligt. Uitval wegens ziekte is het grootst onder vervraegd gepensianeerden. Het totaal aantal uttvallers (33) correspondeert niet met het eerder vermelde aantal van 28 omdat in onze populatie ook niet werkenden opgenomen $z i j n$ die uit de totale bevolkingssteekproef afkomstig zijn. We dienen hierbij op te merken dat vervroegd gepensioneerden de oudste en werklozen de jongste categorie vormen, zoals we in tabel 5.4 zullen zien. Dit impliceert dat ook in geval van correctie op leeftijd het aantal uitvallers onder de arbeldsongeschikten het hoogst blijft. De "overige" andere redenen $z i j n$ onbereikbararheid en weigering.

Tabel 5.4 Vergelijking verdeling werkloze, arbeldsongeschikte en vervraegd gepensioneerde mannen in 1981 en 1983 maar leeftijd $(\%)$

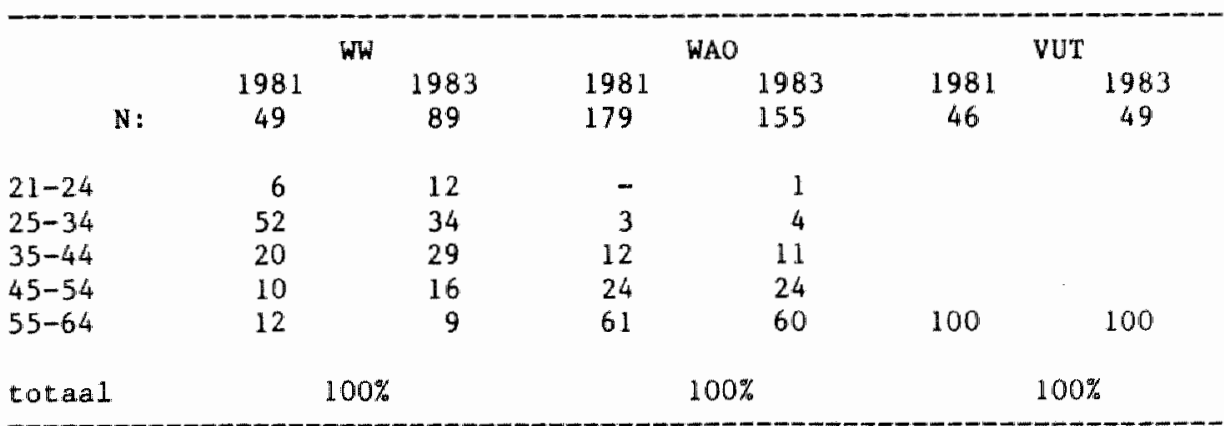


De leeftijdswerdellng (tabel 5.4) blifkt duidelijk te verschillen: werklozen zijn het Jongst (modale klasse 25-34), vervroegd gepensioneerden het oudst, terw 11 arbeidsongeschikten een middenpositie innemen, dichter bij de VuT-ers dan bij de werklozen.

In tabel 5.5 geven een overzicht van de burgerlijke stat.

Tabel 5.5 Vergelijking verdellng werklaze, arbeldsongeschikte en vervroegd gepensioneerde mannen in 1981 en 1983 naar burger1i.jke staat $(\%)$.

\begin{tabular}{|c|c|c|c|c|c|c|}
\hline & \multicolumn{2}{|c|}{ WW } & \multicolumn{2}{|c|}{ WAO } & \multicolumn{2}{|c|}{ VUT } \\
\hline $\mathrm{N}:$ & $\begin{array}{c}1981 \\
49\end{array}$ & $\begin{array}{c}1983 \\
89\end{array}$ & $\begin{array}{l}1981 \\
179\end{array}$ & $\begin{array}{l}1983 \\
155\end{array}$ & $\begin{array}{c}198.1 \\
46\end{array}$ & $\begin{array}{c}1983 \\
49\end{array}$ \\
\hline gehuwd & 74 & 58 & 91 & 83 & 83 & 92 \\
\hline samenwonend * & 2 & 6 & 2 & 5 & 2 & 2 \\
\hline ongehuwd (ngg ${ }^{*}$ ) & 20 & 27 & 2 & 4 & 4 & - \\
\hline geschelden & 4 & 6 & 4 & 4 & 2 & 2 \\
\hline wed uwnaar & - & 1 & 2 & 5 & 9 & 4 \\
\hline onbekend & - & 2 & - & - & - & - \\
\hline totaal & \multicolumn{2}{|c|}{$100 \%$} & \multicolumn{2}{|c|}{$100 \%$} & \multicolumn{2}{|c|}{$100 \%$} \\
\hline
\end{tabular}

* $\mathrm{ngg}=$ niet gehuwd geweest

Werklozen onderscheiden zich door een hoog percentage dat "nooit gehuwd geweest" is, hetgeen naar wij mogen aannemen samenhangt met het grote aantal jongeren binnen deze groep.

De verdeling naar sociaal-economische klasse, berustend op opleiding en laatste beroep, is weergegeven 1 in tabel 5.6 .

Tabel 5.6 Vergelijking werkloze, arbeldsongeschlkte en vervroegd gepenstoneerde mannen in 1981 en 1983 naar sociaal-economische klasse $(\%)$.

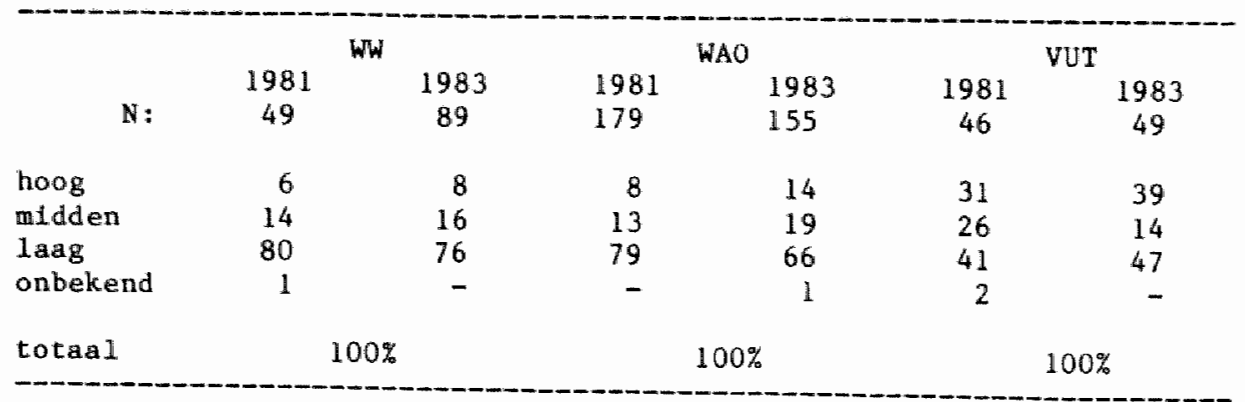


Vervroegd gepensioneerden blijken zich wat betreft sociasl-economische klasse duidelijk te onderscheiden van de overige twee categorieern: een relatief hoog percentage behoort tot de hoge en middenklasse. Bij de arbeidsongeschikten valt het verschil tussen 1981 en 1983 op: in 1983 is het percentage in de hogere klassen hoger dan in 1981 . Bij de werklozen zien we met betrekking tot de sociaal-economische kllasse geen verschuiving. Tot slot wijzen we erop dat in 1983 werklozen voor het merendeel (74\%) korte tijd zonder werk zijn, arbeidsongeschikten daarentegen zijn voor het merendeel (76\%) 2,5 jaar of langer zonder werk. Wan de verwroegd gepensioneerden heeft $60 \%$ sedert korte tijd en $40 \%$ sedert lange tijd het arbeidsleven verlaten. In 1981 is de duur van het niet werken onbekend, omdat deze variabele niet opgenomen werd.

In bijlage I hebben we de verdelingen van de drie categorie ën weergegeven naar landsdeel en urbanisatiegraad voor 1981 en 1983.

We wijzen erop dat de verdeling van het panel over de achtergrondkenmerken niet belangrijk afwijkt van de steekproef van 1981 en 1983 afzonderlijk. Gegevens over het panel staan vermeld in bijlage II.

5.3.2 De prakt1jkpopulatie

5.3 .2 .1 De totale praktijkpopulatie

In de volgende tabel geven we de leeftijdsverdeling van de gemeenschappelijke praktijkpopulatie van de vijf huisartsen.

Tabel 5.7 Leeftijdsverdeling van de prakt1jkpopulatie, gedifferentieerd naar mannen en vrouwen $(\%)$.

\begin{tabular}{rccc} 
Leeftijd & $\begin{array}{l}\text { Mannen } \\
\mathbf{N}=4852\end{array}$ & $\begin{array}{l}\text { Vrouwen } \\
\mathbb{N}=5074\end{array}$ & $\begin{array}{c}\text { Totaa } \\
\mathbf{N}=9926\end{array}$ \\
$0-20$ & 27 & 23 & 25 \\
$21-64$ & 63 & 61 & 62 \\
$\geq 65$ & 10 & 16 & 13 \\
& $100 \%$ & $100 \%$ & $100 \%$ \\
\hline
\end{tabular}


U1t tabel 5.7 blijkt dat van de totale populatie $25 \%$ jonger is dan 21 jatar en $13 \% 65$ jaar en ouder; voor de mannen 1 s dit respectievelijk $27 \%$ en $10 \%$. Dit betekent dat $63 \%$ van de mannen in de voor ons relevante leeftijd van 21 tot 65 jaar valt. Buitenlanders en instellingebewoners die databij inbegrepen $z i j n$, kunnen in dit overzicht niet onderschelden worden omdat niet altijd bekend is welke personen daartoe behoren.

5.3.2.2 De onderzoekspopulatie

In deze paragraaf bespreken we hoe de onderzoekspopulatie tat stand gekomen is en hoe de onderzoekspopulatie er uitziet.

- Beschrijving onderzoekspopulatie naar werken/nlet werken

De doelgroep bestaat uit mannen van 21 tot 65 jaar, met de Nederlandse nationaliteit en niet wonend in instellingen. Gegeven deze omschrijving behoorden 2158 patiënten tot de onderzoekspopulatie. Van hen hebben 1423 personen het formulier ingevuld, van wie $15 \mathrm{zich}$ beperkten tot naam en adres, daarbij aantekenend niet te willen meewerken. De response bedraggt derhalve $65,3 \%$. Voor een ultvoerfige verantwoording verwijzen we naar bijlage III.

We vervolgen nu thet de tabellen 5.8 en 5.9 , die beide gedestilleerd zijn utt de basistabel die onder bijlage IV vermeld staat. In deze basistabel wordt duidelijk hoe beide tabellen in elkaar grijpen. Uit tabe1 5.8 blijkt dat $74 \%$ van de onderzoekspopulatie wit de huisartspraktifken betald werk verricht, voor het merendeel in een volledige baan. Circa cén vijfde verricht geen betaalde arbeid, maar heeft eerder wel gewerkt. De categorle die een oplelding volgt omvat $3 \%$ van het totaal. Het aantal mannen dat het hulshouden verzorgt, dan wel in miltalire dienst vertoeft, is miluder dan $1 \%$. 
Tabel 5.8 Verdeling van de mannelijke praktijkpopulatie van 21-64 jaar naar gerapporteerde voornaamse dagelijkse bezigheden $(\mathrm{N}=1408)$.

\begin{tabular}{lrr} 
& N & \\
- volledige baan & 958 & 70 \\
- deeltijd baan & 58 & 4 \\
- geen werk, maar voorheen & 295 & 21 \\
- betald werk verricht & 38 & 3 \\
- geen werk, volgt opleiding & 4 & \\
- hilitman & 7 & 2 \\
- anders & 32 & \\
& & \\
total dienst & 1392 & 100 \\
niet ingewuld & 16 & \\
\hline
\end{tabular}

In de volgende tabel geven we een overzicht van de verdeling naar onderscheiden 1oon(dervings)woorzieningen waaronder de onderzoekspopulatie valt.

Tabel 5.9 Verdeling van de mannelijke praktijkpopulatie van 21-64 jaar naar gerapporteerde loon(dervings)voorzieningen waaronder een deel van de populatie valt $(\mathrm{N}=1408)$.

\begin{tabular}{|c|c|c|}
\hline & $\mathrm{N}$ & $\%$ \\
\hline - (gedeeltelijk) werkloos & 83 & 6 \\
\hline - volledig arbeidsongeschikt & 184 & 13 \\
\hline - gedeeltelijk arbeldsongeschikt & 35 & 3 \\
\hline - gedeeltelljk werkloos/ & & \\
\hline gedeeltelijk arbeidsongeschikt & 5 & \\
\hline - vervroegde uittredingsregeling & 42 & 3 \\
\hline - functioneel leeftijdsontslag & 4 & \\
\hline - penstioen & 2 & \\
\hline - anders & 1035 & 75 \\
\hline totaal & 1390 & 100 \\
\hline nlet ingevuld & 18 & \\
\hline
\end{tabular}

In tabel 5.9 valt op dat de categorleĕn volledig en gedeeltelijk arbeidsongeschikten aanzienlijk groter zljn dan de categorle (gedeelte$11 j \mathrm{k}$ ) werklozen ( 16 versus $6 \%$ ). De categorle gedeeltelijk werkloos / gedeeltelijk arbeidsongeschikt is zeer klein (5). De in omvang grootste categorie "anders", bestaat voornamelijk uit werkenden. De 42 respondenten die onder een vervroegde uittredingsregeling vallen, omvatten $3 \%$ van het totaal. Wellicht ten overvloede wijzen we erop dat in afwljking van ons landelijke onderzoek, alle verwoegd gepensioneerden VUT-ers zijn. 
De volgende tabel (5.10) geeft een overzicht wan de definitieve onderzoekspopulatie. Het betreft, ulteraard, alleen de niet werkende werklozen, arbeldsongeschikten en vervroegd gepensioneerden.

Tabel 5.10 Definitieve onderzokspopulatie niet werkende mannen uft de praktijkpopulatie.

N

werklozen

a rbeidsongeschikten

vervroegd gepensioneerden

totaal

265
$\%$

24

64

12

Teneinde tot verantwoorde uitspraken te komen over het eventuele verschil in gezondhetd tussen werkenden en niet werkenden, hebben we precisle-matching toegepast, warbij we paren niet werkenden en werkenden gevormd hebben op basis van leeftijd, sociaal-economische klasse en burgerlijke staat. De vergelijkingsgroep werkenden is gerecruteerd ut de 923 respondenten die een wolledige baan hebben. Bij elke niet werkende hebben we een werkende gezocht die in dezelfde leeftijdsklasse zit (maximaal verschil 5 jaar), die tot dezelfde sociaal-economische klasse behoort (respectievelijk: ongeschoolde en geschoolde arbeiders, employées, zelfstandige, hogere en hoge beroepen) en dezelfde burgerlijke staat heeft (respectlevelijk: gehuwd of samenwonend, ongehuwd, weduwnar, gescheiden). Binnen de groep respondenten met betaald werk was nlet voor elke niet werkende een "partner" aanwezig.

Tabel 5.11 geeft een overzlcht wan de aantallen gematchte niet werkenden.

Tabel 5.11 Aantal gematchte nllet werkenden per categorie.

$\begin{array}{ll}\text { totaal } & \text { percentage } \\ \text { antal } & \text { gematchten } \\ \text { niet } & \\ \text { werkenden } & \end{array}$

werklozen

63

68

43

arbeldsongeschikten

170

53

90

vervroegd gepensioneerder

32

75

24

total 1

265

59 
De proportie gematchte niet werkenden varieert per categorie; van de arbeldsongeschlkten is in verhouding tot de andere categoriecrin niet werkenden het laagste percentage gematcht. Dit hangt samen met het feit dat er weinig oudere mannen zijn binnen de lagere social economische klassen die nog betaalde arbeid verrichten.

- Beschrijving onderzoekspopulatie naar achtergrondkenmerken

In tabel 5.12 worden de werkenden en de (gematchte) niet werkenden naar leeftijd beschreven.

Tabel 5.12 Ondexlinge vergelijking van werkende en totale en gematchte niet werkende mannen nar leeftijd $(\%)$.

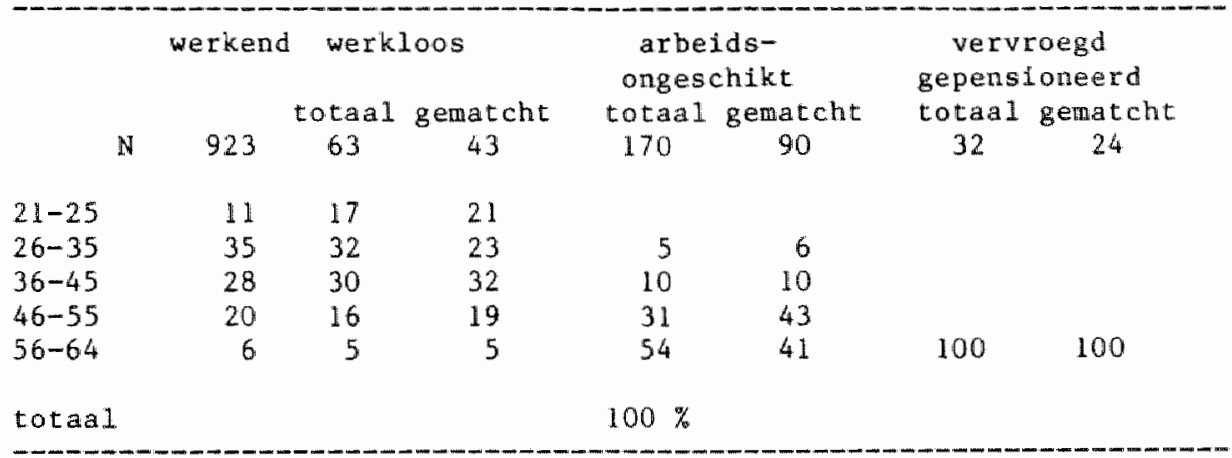

Op grond van deze gegevens kunnen we vaststellen dat de leeftijdsverdeling van gematchte werklozen en arbeidsongeschikten in aanzienlijke mate overeenkomt met de niet gematchten.

In de volgende tabel geven we de vergelljking naar burgerlijke staat.

Tabel 5.13 Vergelijklng van werkende en niet werkende mannen naar burgerlijke stat $(\%)$.

\begin{tabular}{|c|c|c|c|c|c|c|c|}
\hline \multirow[b]{3}{*}{$\mathrm{N}$} & \multirow{3}{*}{$\begin{array}{l}\text { werkend } \\
915\end{array}$} & \multicolumn{2}{|c|}{ werkloos } & \multicolumn{2}{|c|}{$\begin{array}{l}\text { arbeids- } \\
\text { ongeschikt }\end{array}$} & \multicolumn{2}{|c|}{$\begin{array}{l}\text { Wervroegd } \\
\text { gepensioneerd }\end{array}$} \\
\hline & & totaal & gematcht & totas & gematcht & totas & gematcht \\
\hline & & 63 & 43 & 168 & 90 & 32 & 24 \\
\hline gehuwd & 73 & 43 & 58 & 81 & 94 & 94 & 100 \\
\hline samenwonend & 6 & 6 & 7 & 1 & & & \\
\hline ongehuwd & 19 & 33 & 33 & 6 & 5 & & \\
\hline wedumnar & - & 2 & & 2 & & 3 & \\
\hline gescheiden & 2 & 16 & 2 & 10 & 1 & 3 & \\
\hline totaa 1 & & & & $0 \%$ & & & \\
\hline
\end{tabular}


De gematchte categorleän nlet werkenden wljken niet opvallend af van de totale categorleer. Onder de gematchten constateren we bij de werklozen en arbeidsongeschikten een oververtegenwoordiging van gehuwden en een ondervertegenwoordiging van gescheidenen. Bij de vervroegd gepensioneerden is de discrepantie tussen gematchten en niet gematchten kleiner.

De latste tabel betreft de soclaal-economische klasse, in termen van de ITS-code (Deze 15 toebedeeld op basis van het - laatste - beroep en/of opleiding).

Tabel 5.14 Onderlinge vergelijking van werkende en niet werkende mannen naar sociaal-economische klasse $(\%)$.

werkend werkloos

totaal gematcht

N

- ongesch. arbelders

- geschoolde arbeiders

- employés

- zelfst.

- hogere beroepen

- hoge beroepen
774 63

$9 \quad 13$

$23 \quad 35$

$30 \quad 30$

54

$22 \quad 11$

11

7
43

$$
11
$$

32

37

2

11

7

\section{arbeids-} ongeschikt totaal gematcht $70 \quad 90$ 13

$$
40
$$

26

26
7

12

1
7

totan 1 $100 \%$

vervroegd. gepensioneerd totaal gematcht 32 24 4 


\subsection{Toetsing van verschillen}

In dit onderzoek staat het onderling vergelijken van categorieen niet werkenden en werkenden centraal. Afhankelijk van de aard wan de vergelijking, het meetniveau van de onderzoeksgegevens en het type uitspraken dat ons voor ogen staat, hebben we een keuze gemaakt uit het arsenal van statistische technieken.

Een van de door ons meest gebruikte statistische technieken bij de vergelijking van nlet werkenden onderling en van niet werkenden net werkenden is ANOVA (Analysis of Variance), een variantie-analysetechniek (SPSS-manual, 1986). Met behulp van deze techniek worden verschillen getoetst onder constanthouding van variabelen. De constant gehouden variabelen zijn leeftijd, burgerlijke staat en sociaal-economische klasse. Waar niet werkenden onderling vergeleken worden is ook de duur van het niet werken in de rij opgenomen. Een belangrijk voordeel van ANOVA is dat geen voorwaarden gesteld worden aan het meetniveau. De keuze voor ANOVA is mede ingegeven door het betrekkelijk kleine antal respondenten; een alternatief van deze multivarlate analysetechniek zou bivariate analyse kunnen $z i j n$ met behulp van kruistabellen. Om echter de met de afhankelijke varlabele verondersteld gerelateerde variabelen constant te houden zou elaboratie noodzakelijk zijn. Deze techniek is én nogal bewerkelijk ên confronteert de onderzoeker noodzakelijkerwijs met klelne aantallen. De keuze voor ANOVA vloeit voort uit de probleemstelling en de hypothesen: de verschlllen en overeenkomsten tussen categorieën willen we fmmers alleen en uitsluitend in relatie brengen met de werkstatus, hetgeen met $z$ ich meebrengt dat we de effecten van achtergrondkenmerken en de duur van het niet werken moeten ultsluiten. De resultaten van de hoofdstukken 8, 13, 14 en 17 berusten op berekeningen met behulp wan ANOVA.

Tenelnde uttslutsel te krijgen over de ongecorrigeerde verschillen en overeenkomsten tussen enerzijds niet werkenden onderling en anderzijds tussen niet werkenden en werkenden, hebben we gezondheidsclusters geconstrueerd van respondenten. Hoewel we ook andere technieken hadden kunnen toepassen geeft de gekozen benadering de mogelijkheld vast te stellen hoe respondenten individueel over de onderschelden gezondheidsvariabelen verdeeld zijn. Hierbij hebben we gebruik gemaakt van 
similarite1tscoefficlenten yan Gowet (1971), ondat het hierdoor mogelijk is gexondheldsvarlabelen van verschHllende orde met elkar te vergelijken. Langs deze weg zijn overeenkomsten vastgesteld tussen respondenten op basis van hun scores op de simllariteitsmatrix. Vervolgens $z 1 j n$ deze respondenten volgens de "complete linkage" methode over de clusters verdeeld (BMDP, 1987). In hoofdstuk 10 bespreken we deze methode ultwoeriger. Een kruistabel van deze clusters met niet werkenden en werkenden levert een ongecorrigeerd gezondheldsproflel op.

Vergelijking van het ongecorrlgeerde en gecorrigeerde profiel geeft de mogelijkheid een schatting te maken van de relatieve invloed van de onder controle gehouden variabelen ten opzlichte van de werkstatus.

Discriminantanalyse is toegepast om uitsluitsel te krijgen over de specifieke bijdrage van werkstatus, achtergrondkenmerken en duur niet werken, en de gezamenlijke overige in dit onderzoek gebruikte varlabelen, aan de verklaring van verschillen in gezondheld tussen de respondenten die eerst in het gezondheidscluster naar gezondheid gehomogeniseerd $z i j n$. De meeste resultaten van hoofdstuk 10 berusten op clusteranalyse; enkele berusten op discriminamtanalyse.

De vierde - strikt genomen niet statistische - methode die in dit onderzoek gebruikt is, is precisie-matching. Een gedeelte van de resultaten van de hoofdstukken 9 en 18 berust op deze methode. Met deze methode wordt beoogd de invloed van mogelljk "storende" varlabelen op de afhankelijke varlabele (gezondheld) gelijkelijk te laten varlëren over categorleën die met elkaar vergeleken worden (Segers en Hagenaars, 1980). Precisle-matching brengt derhalve met $z i c h$ mee dat de storende varlabelen in de verschillende te vergelijken onderzoeksgroepen met dezelfde relatieve frequentie voorkomen.

Uiteraard veronderstelt een dergelijke methode dat men de mogelijk storende variabelen moet kennen.

Een nadeel van deze op zich elegante methode is dat respondenten kunnen uitvallen omdat geen geschikte vergelijkingspartner gevonden kan worden. Aan de keuze am in de huisartspraktijken niet werkenden met werkenden te matchen ligt in de eerste plaats een praktisch argument ten grondslag. Het was bij de start van het praktijk-onderzoek 
miet duidelijk of de gegevenswerzameling binnen de geplande periade afgerond kon worden. Er waren elders in de eerste lijn immers nog geen ervaringen met het vaststellen vam probleemlijsten en het ten behoeve daarvan classificeren van problemen met behulp wan de ICPC. Daarenboven verkeerde het computerprograma van het HIos nog in een experimenteel stadium. Derhalwe hebben we op basis van de verzamelde achtergrondgegevens van patienten eerst precisie-matching toegepast om eventueel uitsluitend op basis hiervan tot voorlopige conclusies te kunnen komen. De planning bleek inderdaad niet gehaald te worden, maar desondanks hebben de huisartsen in tweede instantie ook de probleemlijsten gemaakt van de niet werkende arbeidsongeschikten, werklozen en vervroegd gepensioneerden die buiten de gematchte populaties vielen. Dit gaf ons de mogelijkheid te controleren of de gematchte niet werkenden afweken wan de totale categarieën, nadat we eerder al vastgesteld hadden dat $\mathrm{zij}$ in achtergrondkenmerken overeenkwamen.

De door ons gebruikte Chi-kwadraat toets en de Fischer's Exact ProbabIlity Test (hoofdstuk 9 en 10) hebben we gekozen om in geval wan kruistabellen tot uitspraken te komen over al dan niet statistische verschillen.

Resteren nog twee gebruikte technieken, de Mann-Whitney U-Wilcoxon Rank Sum W Test en de Wilcoxon Matched Pairs S1gned Rank Test (hoofdstuk 18). Beide zijn non-parametrische toetsen warmee verschilien tussen al dan niet gematchte graepen getoetst zijn. Voor meer informatie hierover verwijzen we onder andere naar eén van de SPSS-manuals.

De in de tabellen vermelde getallen warbij met behulp wan ANONA getoetst is of de drie categorieën niet werkenden verschlilen, resulteren ult Eén analyse. De uitspraken over verschllien tussen twee categorieën berusten op afzonder1ijke ANOVA's; de witkamsten kunnen enigszins afwijken van die welke in de tabellen zijn verneld.

Toetsing van verschillen op basis wan hypothesen, gebeurde steeds eenzijdig. Voor zover geen hypothesen geformuleerd waren, vond exploratie van verschillen plaats op basis van tweezijdige toetsing. De getallen in de tabellen waar toetsing plaatsvond wet behulp van de Mann-Whitney U-Wilcoxon Rank Sum W Test ên de Wilcoxon Matched Palrs Signed Rank Test hebben we verkregen met behulp van de T-test. Gelet op het 
karakter van het materlaal én de onbekendheid over de verdeling van de populatie over de variabelen van waruit de steekproeven afkomstig zifn, berusten de ultspraken over de verschillen niet op deze test.

\subsection{Samenvatting}

In dit hoofdstuk zijn de onderzoekmethoden en de populaties besproken wan de twee onderzoeken warop de resultaten van de volgende hoofdstukken gebaseer $z^{i j n}$. In paragraaf 5.2 zijn het panelonderzoek en het onderzoek onder de praktijkpopulatie aan de orde gesteld. Paragraaf 5.3 belicht de belde populatie-samenstellingen. Wat de panelstudie betreft hebben we een verantwoording gegeven van de veranderlng in populatie tussen de pelljaren 1981 en 1983. De uitval wegens ziekte en sterfte onder de categorieën niet werkenden wordt apart toegelicht; de ultval wegens sterfte blijkt het hoogst onder de arbeidsongeschikten. Tevens hebben we de populatie ult de landelijke steekproef en de huisartspraktijken beschreven naar achtergrondkenmerken. Daarenboven is de genatchte populatie in kaart gebracht en vergeleken met de niet gematchte populatie. In paragraaf 5.4 zijn de statistische methoden besproken en verantwoord. 


\section{Afsluiting Deel I}

Met voorgaande hoofdstukken hebben we ons onderzoek ingeleid: enerzijds door het thema werkenden en niet werkenden nader uit te werken teneinde de matschappelijke owvang van het niet werken duidelijk te maken, anderzijds door de relatie tussen niet werken en gezondheid onder de loep te nemen.

Er is onder meer naar voren gekomen dat er sprake is van cegenstrijdige bevindingen op een aantal punten:

- de mate waarin arbeidsongeschikten, werklozen en vervroegd gepensioneerden naar gezondheid onderling uitwisselbare categorie ën zijn;

- de mate warin gedwongen niet werken, vooral werkloos zijn, tot omgezondheid leidt;

- de mate waarin gedwongen niet werken tot riskante gewoonten en social isolement leidt.

Een en ander heeft ertoe geleid dat we zoals in hoofdstuk 4 naar voren kwam, gezondheid centraal gesteld hebben. Daarnaast hebben we er voor gekozen riskante gewonten en particlpatie in het onderzoek te betrekken. Centraal in dit onderzoek staat de vergelijking van de drie categorieën nïet werkenden onderling en met werkenden naar gezondheid. Gellet op de methodologische kritieken (op vooral buitenlands onderzoek) en de daaruit voortvloeiende anbevelingen hebben we wat de invloed van de duur niet werken betreft gekozen voor transversale en longitudinale analyses op micro-niveau tenelnde tot verantwoorde ultspraken te komen; tevens hebben we ervoor gekozen werkenden als contrastgroep in het onderzoek te betrekken. Een en ander is uitgewerkt in de hoofdstukken 4 en 5 . 
In de volgende delen II, III en IV komen de onderzoekresultaten aan de orde. Elk deel omvat een afgegrensd thema. In deel. II beperken we ons. tot gezondheld en gezondheidsopvattingen. In deel III komen riskante gewoonten en particlpatie aan de orde. In belde delen worden arbeldsongeschikten, werklozen en vervroegd gepensioneerden met elkar en met werkenden vergelekew. In deel IV worden de in de delen II en III behandelde onderwerpen in relatie tot de duur wan het niet werken besproken.

In het vijfde en laatste deel geven we de conclusies en nabeschouwing weer alsmede de samenwating. 


\section{Deel II: Gezondheid en Gezondheidsopvattingen}

7. Inleiding Deel II

8. Gerapporteerde Gezondheid en Gezondheidsopvattingen

9. Gezondheid, vastgesteld door Huisartsen

10. Consistentie van de Gezondheidsmeting

11. Conclusies en Discussie 


\section{Inleiding Deel II}

De in het vierde hoofdstuk geformuleerde hypothesen over gezondheid worden in dit deel getoetst. Dit geldt niet voor de hypothesen met betrekking tot de durr van het niet werken; deze komen in deel IV aan de orde.

De resultaten vermeld in hoofdstuk 8 hebben betrekking op de gerapporteerde gezondheld van niet werkenden uit de landelijke steekproef. Naast gezondheld komen in hoofdstuk 8 ook de gezondheldsopvattingen ter sprake; dit vanwege de sterkere samenhang van deze opwattingen met de beleving van ziekte en gezondheid dan met gezondheids- en ziektegedrag (Halfens et al., 1988).

Hoofdstuk 9 beschrijft onderzoeksresultaten uit de huisartspraktijken; deze betreffen de door huisartsen vastgestelde gezandheid van niet werkenden en werkenden. Aan de hand van de gegevens hieromtrent toetsen we de resultaten met betrekking tot door niet werkenden zelf gerapporteerde gezondheid. In de conclusies van de hoofdstukken 8 en 9

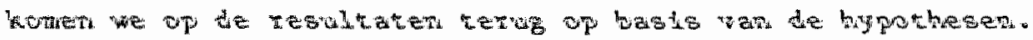

In aansluteing op het in hoofdstuk 5 vermelde, wijzen wij er nogmals op dat de ultkomsten in het kader van de geformuleerde hypothesen Eenzijdig, en de uitkomsten in het kader van de exploratle, tweezijdig getoetst zijn* Het gedeelte van de onderwerpen waraver we geen hypothesen geformuleerd hebben, past in deze exploratie.

Alle in hoofdstuk 8 vermelde getallen zijn gemiddelden. Zoals vermeld In hoofdstuk $5 \mathrm{zijn}$ dit gecorrigeerde cijfers, dat wil zeggen dat we de Invloed van achtergrondkenmerken statistisch uitgeschakeld hebbem. Onderlinge overeenkomsten en verschllien die hier gerapporteerd worden, kunnen derhalve niet teruggevoerd worden op verschillen in leeftijd, soclaal-economische klasse en burgerlijke staat. Bij de vergelijking van niet werkenden onderling hebben we ook gecorrigeerd voor verschillen in de duur van het niet werken. 
Ter voorkoming van misverstanden wijzen we nog op het volgende: uitspraken over werschillen per variabele tussen twee categorieen niet werkenden onderling ( $A O$ met WW; $A O$ met VUT; Wh met VUT) berusten op ANOVA. De cijfers in de tabellen berusten op ANova van alle drie categorieën tezamen. Zij hoeven niet overeen te komen met de ultkonsten van de vergelijking van twee categorieën. Vanwege de overzichtelijkheld hebben we hiervoor gekozen. In elke tabel van hoofdstuk 8 van dit deel (en van de hoofdstukken uit deel III) is de kolom "toetsing verschillen" opgenomen. In deze kolom staat per varlabele de ultkomst van drie verschillende vergelijkingen vermeld, op basis van ANOVA na correctie op verschillen in achtergrondkenmerken en duur van het niet werken. Wanneer er bij de drie vergelljkingen geen verschillen naar voren komen, is de cel blanco gelaten. We wijzen erop dat in alle tabellen arbeidsongeschikten weergegeven worden met AO, werklozen met WW, en vervroegd gepensioneerden met VUT. De afkorting VUT, uitgezonderd hoofdstuk 9 , is strikt genomen niet juist, omdat zoals eerder vemeld, onder vervroegd gepenstoneerden vuT-ers vallen, mar aok personen die om andere redenen vobr hun 65 e jaar gepensloneerd zijn. In hoofdstuk 9 staat de afkorting. WUT voor echte vUT-ers.

In het tiende hoofdstuk gaan we nog eens na hoe consistent de bevindingen van hoofdstuk 8 zijn. We doen dit langs twee wegen: in de eerste plats stellen we vast of de panelstudie in 1981 hetzelfde gezondheidsprofiel oplevert; in de tweede plaats toetsen we de robunstheid van de resultaten van hoofdstuk 7 door de onderzoeksgegevens nog eens op een andere manier te benaderen, namelifk via clusteranalyse. Deze techniek geeft ons bovendlen de mogelijkheld vast te stellen hoe de afzonderlijke categorieën niet werkenden en de categorle werkenden verdeeld zijn over zleken en gezonden. In hoofdstuk 11 tenslotte vatten we de bevindingen nog eens samen in de vorm van conclustes en discussie. 


\section{Gerapporteerde Gezondheid en Gezondheidsopvattingen}

\subsection{Inleiding}

In dit hoofdstuk bespreken we de resultaten van de analyse warin niet werkenden onderling en met werkenden zijn vergeleken naar achtereenvolgens gezondheld en gezondheidsopvattingen.

De opbouw van dit hoofdstuk is als volgt: In de paragrafen 8.2 en 8.3 worden de drie onderscheiden categorieën niet werkenden met elkaar vergeleken. Daarna wordt in de paragrafen 8.4 en 8.5 elke categorie af zonderlijk vergeleken met werkenden.

\subsection{Een onderlinge vergelijking van niet werkenden naar gezondheld}

In tabel 8.1 geven we een vergelijkend overzicht wan de gezondheld van de drie categorleẻn niet werkenden.

Arbeldsongeschikten hebben in vergelijking met werklozen en wervroegd gepengioneerden een slechtere score op alle gezondheidsmaten. Arbeidsongeschlkten hebiben:

- vaker een chromische aandoening: $69 \%$ versus $21 \%$ en $36 \%$;

- frequenter contact met een arts (huisarts of specialist): 6,1 keer per faar versus 1,1 en 2,1 keer per jaar;

- meer lichamel1jke klachten: 15,6 versus 7,9 en 7,6 klachten;

- een slechtere beoordeling van de elgen gezondheld: matig versus goed;

- een hoger percentage gebruikers van medicijnen op eigen initiatief ( $53 \%$ versus $31 \%$ en $32 \%$ ) en een groter medicijngebruik onder de gebruikers ( 75 versus 31 en 25 medicijnen per maand);

- vaker zorgen over hun elgen gezondheid: soms versus zelden. 
Tabel 8.1 Arbeidsongeschikte, werkloze en vervroegd gepensioneerde mannen onderling vergeleken naar gezondheid (1983).

\begin{tabular}{|c|c|c|c|c|}
\hline & $\begin{array}{c}\mathrm{AO} \\
(1) \\
(\mathrm{N}=1.55)\end{array}$ & $\begin{array}{c}W W \\
(2) \\
(N=87)\end{array}$ & $\begin{array}{c}\text { VUT } \\
(3) \\
(N=48)\end{array}$ & $\begin{array}{l}\text { toetsing } \\
\text { verschilien }\end{array}$ \\
\hline $\begin{array}{l}\% \text { chronische } \\
\text { aandoening }\end{array}$ & 69 & 21 & 36 & $\begin{array}{l}1 \neq 2,3^{* * *} \\
2=3\end{array}$ \\
\hline $\begin{array}{l}\text { doktersbezoeken } \\
\text { afgelopen jaar } \\
\text {-frequentie- }\end{array}$ & 6,1 & 1,1 & 2,1 & $\begin{array}{l}1 \neq 2,3^{* * *} \\
2=3\end{array}$ \\
\hline $\begin{array}{l}\text { score lichame- } \\
\text { lijke klachten. }\end{array}$ & 15,6 & 7,9 & 7,6 & $\begin{array}{l}1 \neq 2,3^{* * *} \\
2=3^{* *}\end{array}$ \\
\hline $\begin{array}{l}\text { beoordeling eigen } \\
\text { gezondheid }\end{array}$ & $\begin{array}{l}\operatorname{mat} 1 \mathrm{~g} \\
(3,3)\end{array}$ & $\begin{array}{l}\text { goed } \\
(4,1)\end{array}$ & $\begin{array}{l}\text { goed } \\
(4,0)\end{array}$ & $\begin{array}{l}1 \neq 2,3^{* * *} \\
2=3\end{array}$ \\
\hline $\begin{array}{l}\text { medicijngebruik } \\
\text { op eigen initiatief }\end{array}$ & & & & \\
\hline $\begin{array}{l}\text { - \% medicijngebrui- } \\
\text { kers }\end{array}$ & 53 & 31 & 32 & $\begin{array}{l}1 \neq 2,3^{* *} \\
2=3\end{array}$ \\
\hline $\begin{array}{l}\text { - antal medicijnen/ } \\
\text { maand (gebruikers) }\end{array}$ & 75 & 31 & 25 & $\begin{array}{l}3=1,2 \\
1 \neq 2\end{array}$ \\
\hline $\begin{array}{l}\text { zorgen eigen } \\
\text { gezondheid }\end{array}$ & $\begin{array}{l}\text { soms } \\
(2,7)\end{array}$ & $\begin{array}{l}\text { zelden } \\
(1,4)\end{array}$ & $\begin{array}{l}\text { zelden } \\
(2,1)\end{array}$ & $\begin{array}{l}1 \neq 2,3^{* *} \\
2=3\end{array}$ \\
\hline 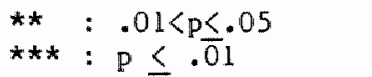 & & \multicolumn{3}{|c|}{ eenzijdig getoetst } \\
\hline
\end{tabular}

Ten aanzien van het aantal medicljnen blijken arbeldsongeschikten niet van vervroegd gepensioneerden, mar wel van werklozen te verschillen. Werklozen en vervroegd gepensioneerden verschillen wat gezondheid betreft niet.

We concluderen dat arbeidsongeschikten een intrinsiek slechtere gezondheid rapporteren dan werklozen en vervroegd gepensloneerden. Werklozen en vervroegd gepensioneerden verschillen onderling nagenoeg niet. 
8.3 Een onderlinge vergelijking vam nlet werkenden naar gezondheidsopvattingen

Tabel 8.2 geeft een overzicht van de gezondheidsopvattingen van de dre categorleën ntet werkenden. De scores inzake het belang van gezondheld kunnen warlëren van 3 (van klein belang) tot 15 (van graot belang). De drle dimensies van de beheersingsorlëntatie kunnen varieren van score 6 (laag) tot score 36 (hoog).

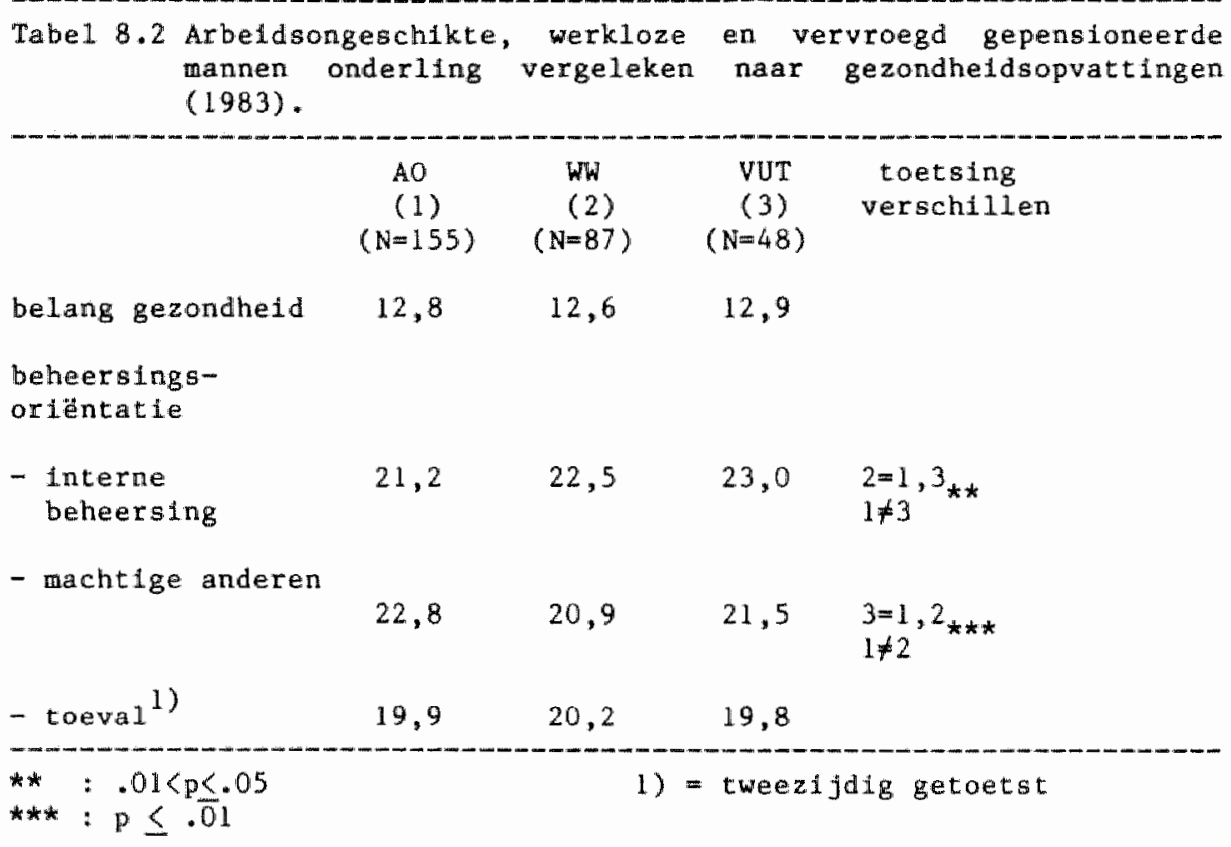

De drle categorieën niet werkenden komen op twee van de vier aspecten van gezondheldsopvattingen overeen: opvattingen over het belang van gezondheld en de toevalsdimensie van de orlëntatie.

Het beeld op de overige twee aspecten is gedifferentieerd:

- werklozen konen wat interne oriëntatie betreft overeen met beide andere categorieën; vervroegd gepensioneerden blijken een hogere score te hebben dan arbeidsongeschikten;

- vervroegd gepensioneerden komen in de oriëntatie op machtige anderen overeen met beide andere categorieën; arbeidsangeschikten hebben hlerin een hogere score dan werklozen. 
8.4 Een vergelljking van werkenden en niet werkenden natar gezondheid

In deze paragraaf zullen we werkenden met arbeidsongeschikten, werklozen en vervroegd gepensioneerden vergelijken.

Onwille van de leesbaarheid zullen we in de tabel geen cijfers weergeven, maar alleen vermelden of er overeenkomsten, dan wel (significante) verschillen bestaan. In de bespreking van de tabellen geven we alleen de cijfers weer, wanneer er verschilien blijken te aijn.

Tabel 8.3 geeft de resultaten van de vergelijking weer.

Tabel 8.3 werkende $(\mathrm{N}=412)$ en niet werkende mannen, vergeleken naar gezondheld (1983).

\begin{tabular}{|c|c|c|c|}
\hline & \multicolumn{3}{|c|}{ werkenden vergeleken met: } \\
\hline & $\mathrm{AO}$ & WW & VUT \\
\hline $\begin{array}{l}\text { \% chronische } \\
\text { aandoening }\end{array}$ & $\min i^{* \star *}$ & 0 & 0 \\
\hline $\begin{array}{l}\text { doktersbezoeken } \\
\text { afgelopen jaar } \\
\text {-freq.- }\end{array}$ & $\mathrm{mi} i^{* * *}$ & 0 & 0 \\
\hline $\begin{array}{l}\text { score lichame- } \\
\text { lijke klachten }\end{array}$ & $m i^{\star \star \star}$ & 0 & $m e^{* *}$ \\
\hline $\begin{array}{l}\text { neg. beoordeling } \\
\text { eigen gezondheid }\end{array}$ & $\operatorname{mi}{ }^{\star \star *}$ & 0 & 0 \\
\hline $\begin{array}{l}\% \text { medici jngebrui- } \\
\text { kers op eigen } \\
\text { intiatief }\end{array}$ & $\min i^{\star * *}$ & 0 & 0 \\
\hline $\begin{array}{l}\text { aantal medicijnen } \\
\text { per maand op elgen } \\
\text { inttiatief (gebr.) }\end{array}$ & $\operatorname{mi} i^{\star \star \star}$ & 0 & 0 \\
\hline $\begin{array}{l}\text { zorgen eigen } \\
\text { gezondheid }\end{array}$ & $\min 1^{\star * *}$ & 0 & 0 \\
\hline $\begin{array}{l}* *: 01 \leq \mathrm{p} \leq .05 \\
\star * *: \mathrm{P} \leq .01 \\
0=\text { geen significan }\end{array}$ & & & \\
\hline
\end{tabular}


De vergelljking van werkenden met arbeldsongeschikten geeft een homogeen beeld te zien: blj alle gezondheldsaspecten vinden we zeer duide$11 \mathrm{jk}$ onderlinge werschillen.

Werkenden hebben in wergeldjking wet arbeldsongeschikten (de cijfers betreffen de vergelijking in de eerste kolom):

- minder chronische aandoeningen: $31 \%$ resp. $68 \%$;

- rinder frequent contact met een arts: 2,1 resp. 6,2 ;

- minder lichamelijke klachten: 8,1 resp. 15,1;

- een positiever oordeel over de elgen gezondheld: goed resp. matig;

- een lager percentage medicijngebruikers: $34 \%$ resp. 50\% (werkenden en kortdurig arbeldsongeschikten komen overeen);

- een geringer medicijngebrulk op elgen initiatlef per maand onder de gebrulkers: 12,7 resp. 39,0 ;

- minder zorg over de eigen gezondheid: zelden resp. soms.

De tweede kolom geeft eveneens een homogeen beeld: werkenden blijken van werklozen niet te verschillen.

Werkenden blijken evenmin te verschillen van vervroegd gepensioneerden. Er is Eén ultzondering: zij blijken meer lichamelijke klachten te hebben, namel1jk 7,9 versus 6,3 .

8.5 Een vergelijking van werkenden en niet werkenden naar gezondheidsopvattingen

Conform de opzet van de vorige paragraaf presenteren we nu de onderlinge vergelifking naar gezondheidsopvattingen. In tabel 8.4 vermelden we de resultaten.

Werkenden komen met arbeidsongeschikten overeen in hun opvattingen over het belang van gezondheld en wet betrekking tot de toevalsorientatie. Wat interme beheersing en machtige anderen betreft blijken werkenden van arbeidsongeschikten te verschillen: werkenden zijn meer van mening dat $2 i j$ hun eigen gezondheid kunnen beinvloeden $(22,7$ versus 21,3 ) en zijn minder de opvatting toegedaan dat machtige anderen hun gezondheid kunnen beInvloeden $(19,7$ versus 21,8$)$. 
Werkenden verschillen niet wan werklozen.

Werkenden blijken miet te verschillen van vervroegd gepensioneerden in de interne en toevalsoriëntate. Wel vinden we verschilien in opvattingen over het belang van gezondheid en de oriëntatie op machtige anderen: werkenden hechten minder belang aan gezondheid $(12,0$ versus 12,7); daarnaast zijn zij minder van mening dat machtige anderen de gezondheid kunnem beInvloeden $(19,3$ versus 21,2$)$.

Tabel 8.4 Werkende $(\mathbb{N}=412)$ en niet werkende mannen, vergeleken naar gezondheidsopvattingen (1983).

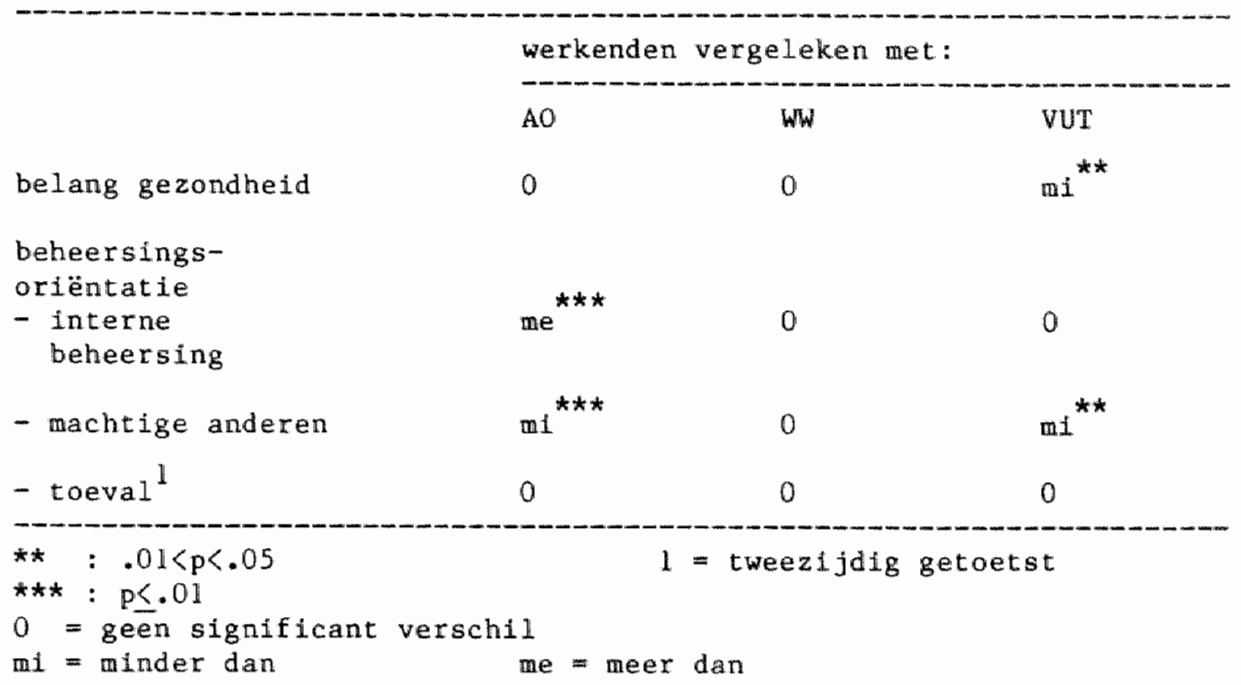

\subsection{Conclustes}

In deze paragraaf geven we zowel conclusles met betrekking tot de in hoofdstuk 4 geformuleerde hypothesen, als conclusies op basis van bevindingen warower geen hypothesen geformuleerd $z 1 j n$. Achtereenvolgens bespreken we de thema's gerapporteerde gezondheid en gezondheidsopvattingen. Omwille wan de overzichtelijkheid zullen we de hypothesen herhalen. Telkens onderscheiden we twee vergelifkingen: tussen niet werkenden onderling en tussen niet werkenden en werkenden. 
8.6. Lerapporteerde gezondhedd

Set 1 Wet werkenden anderling

$\begin{array}{ll}\text { hypothese } & \text { opmerkingen / } \\ \text { bevestigd } & \text { bijzonderheden }\end{array}$

1.1 Arbeldsongeschikten hebben

a. een slechtere subjectleve gezondheld dan

- werklozen ja

- vervroegd gepensioneerden ja

b. een slechtere objectieve gezondheld dan

- werklozen ja

- vervroegd gepensiloneerden ja niet in medicijngebruik

1.2 Werklozen hebben

a. een slechtere subjectieve gezondheid dan

- vervroegd gepensioneerden neen geen verschil

b. eenzelfde objectleve gezondheid als

- vervroegd gepensioneerden ja

Onze hypothesen blijken merendeels bevestigd te worden zoals uit voorgand overzlcht blijkt: arbeidsongeschikten blijken een intrinsiek slechtere gezondheid te hebben dan werklozen én vervroegd gepensioneerden.

Set 2 Niet werkenden en werkenden

$$
\begin{array}{ll}
\text { hypothese } & \text { opmerkingen / } \\
\text { bevestigd } & \text { bijzonderheden }
\end{array}
$$

2.1 Arbeidsongeschikten hebben

a. een slechtere subjectieve gezondheld dan werkenden ja

b. een slechtere objectieve gezondheid dan werkenden 


\subsection{Werklozen hebben}

a. een slechtere subjectieve gezondheid dan werkenden geen verschil

b. eenzelfde objectieve gezondheid als werkenden ja

\subsection{Vervroegd gepensiloneerden komen}

met werkenden overeen in:

a* de subjectieve gezondheid

b. de objectieve gezondheid

Ook deze hypothesen worden op én na bevestigd; vergeleken met werkenden hebben arbeidsongeschikten een intrinsiek slechtere gezondheld. Vervroegd gepensioneerden komen nagenoeg en werklozen komen geheel met werkenden overeen. De verwachte slechtere subjectieve gezondheid van werklozen vergeleken met werkenden wordt niet bevestigd. Opvallend is dat werklozen en werkenden niet van elkaar verschillen in subjectieve gezondheid.

\subsubsection{Gezondheidsopvattingen}

Set 1 Niet werkenden onderling

$\begin{array}{ll}\text { hypothese } & \text { opmerkingen } / \\ \text { bevestigd } & \text { bijzonderhederi }\end{array}$

Belang gezondheld

1.1 Arbeidsongeschikten achten gezondheld belangrijker dan

a. werklozen

neen

geen versch11

b. vervroegd gepensioneerden

neen geen verschil

1.2 Werklozen achten gezondhe1d even belangrijk als vervroegd gepensioneerden 
Interne beheersingsorientatie

1.3 Arbeldsongeschlkten hebben een

lagere interne orfentatie dan

a. werklozen

neen

geen verschil

b. vervroegd gepensloneerden

ja

1.4 Werklozen komen overeen in de interne orientatie met

verwroegd gepenstoneerden

ja

Externe beheersingsorlëntatie

1.5 Arbeidsongeschikten hebben een hogere externe oriëntatie dan

a. werklozen

ja

b. vervroegd gepensioneden

neen

geen verschil

\subsection{Werklozen komen overeen in}

externe oriëntatie met

vervroegd gepensioneerden

ja

Van onze drie hypothesen over het belang van gezondheid worden er twee verworpen. Gelet op de verschillen in gezondheid tussen enerzijds arbeidsongeschikten en anderz1jds werklozen en vervroegd gepensioneerden werbast het ons wel dat deze twee hypothesen verworpen worden.

De hypothesen over de lnterne beheersingsoriëntatie worden in twee van de drie gevallen bevestigd. Niettemin verbaast het ons dat arbeldsongeschikten en werklozen onderling overeenkomen terwijl arbeidsongeschikten we1 lager scoren dan vervroegd gepensioneerden. Ondat arbeidsongeschikten wêl verschillen van vervroegd gepensioneerden, maar werklozen en vervroegd gepenstoneerden weer onderling overeenkomen is er geen reden om te veronderstellen dat gedwongen niet werken samenhang vertoont met de interne beheersingsoriëntatie.

Ook de hypothesen over de orientatie op machtige anderen worden in twee van de drle gevallen bevestigd: arbeldsongeschikten zijn de enigen die zich onderscheiden door een hogere oriëntatie en wel alleen ten opzichte van werklozen. 
Wat betreft de toevalsoriëntatie - waarover we geen hypothesen geformuleerd hebben - vinden geen onderlinge verschilien.

Set 2 Niet werkenden en werkenden

$$
\begin{array}{ll}
\text { hypothese } & \text { opmerkingen } / \\
\text { bevestigd } & \text { bljzonderheden }
\end{array}
$$

Bellang gezondheid

2.1 Arbeidsongeschikten achten

gezondheid belangrijker dan

werkenden neen geen verschll

$2.2 a$ Werklozen achten gezondheid even belangrijk als werkenden ja

b Vervroegd gepensioneerden achten gezondheid even belangrijk als werkenden

Interne beheersingsoriëntatie

2.3 Arbeidsongeschikten hebben een

lagere interne oriëntatie dan werkenden

2.4a Werklozen hebben eenzelfde

interne oriërtatie als

werkenden

ja

b Vervroegd gepensioneerden hebben

eenzelfde interne orientatie

als werkenden

Externe beheersingsariënatie

2.5a Arbeidsongeschikten hebben een

hogere externe orlëntatle dan

werkenden

ja

b Werklozen hebben eenzelfde

externe oriëntatie als werkenden ja

c Vervroegd gepensioneerden

hebben eenzelfde externe

oriëntatie als werkenden 
Twee van de drle hypothesen over het belang dat aan gezondheid gehecht wordt, worden verworpen: arbeldsongeschikten verschilien niet van werkenden, terwjl verwroegd gepensloneerden mét belang aan gezondheid hechten dan werkenden.

De drie hypothesen over de interne oriëntatle worden alle bevestigd. Conform onze verwachting onderscheiden allển arbeldsongeschikten zich van werkenden en wel door een lagere orlëntatle.

Twee van de drie hypothesen over de externe orlëntatle worden bevest1gd: arbeldsongeschikten hebben een hogere externe oriëntatie dan werkenden en werklozen verschillen niet van hen. Dat de vervroegd gepensianeerden een hogere oriëntatie blijken te hebben dan werkenden, hadden we niet verwacht.

\subsection{Samenwatting}

Arbeidsongeschikten rapporteren overwegend een slechtere gezondheid dan werklozen en vervroegd gepensioneerden, terwijl de laatste twee onderling niet verschillen.

De drie categorieën niet werkenden verschillen niet in opvatting over het belang van gezondheid; zij verschillen evenmin in toevalsoriëntatie. In de interne orlëntate verschillen de werklozen vanuit een tussenpositie niet van belde andere categorieën, terwijl arbeldsongeschikten in vergelijking met vervroegd gepensioneerden van mening zijn minder invloed op de elgen gezondheid te hebbea.

In de oriëntatle op machtige anderen verschillen vervraegd gepensioneerden niet van belde andere categorleën; arbeidsongeschikten $z 1 j n$ in vergelfjking met werklozen echter van mening dat machtige anderen mécr inwloed op hun gezondheld kunnen ultoefenen.

Werkenden rapporteren een betere gezondheid dan arbeidsongeschikten en verschillen op dit punt niet van werklozen en vrijwel niet van vervroegd gepensioneerden; werkenden rapporteren alleen meer lichamelijke klachten dan vervroegd gepensioneerden. 
Werkenden blijken $z$ ich voorts van arbeidsongeschikten vooral te onderscheiden door een hogere interne beheersingsariëtatie en een lagere orientatie op machtige anderen; vergeleken met vervroegd gepensioneerden blijken zij zich te onderscheiden door minder belang te hechten aan gezondheid en een lagere oriëntatie op machtige anderen. Werkenden en werklozen, tot slot, verschillen niet. 


\section{Gezondheid, vastgesteld door Huisartsen}

\subsection{Inleiding}

In dit hoofdstuk vergelijken we de eerder in hoofdstuk 5 beschreven nlet werkende en werkende mannelijke patiënten ult de huisartspraktijk met elkaar. Ging het in hoofdstuk 8 om de gerapporteerde gezondheid, In dit hoofdstuk staat de gezondheld centraal zoals deze door de huisarts vastgesteld 1s. Met behulp van gegevens uit de praktijk kunnen we nagaan of de door huisartsen vastgestelde gezondheid wan mannelijke werkende en niet werkende patiënten overeenkomt met de zelfrapportage hierontrent in het panelonderzoek. Zoals ult hoofdstuk 4 blijkt, is de gezondheid vastgesteld met behulp van de probleemlijst en het aantal huisarts-patiënt contacten over 1986. De probleemlijst achten wij een meer valide indicator voor de objectleve gezondheld ondat de op de probleemlijst vermelde problemen niet alleen berusten op bevindingen van de hulsarts zelf, maar ook op bevindingen van andere hulpverleners uit de eerste en tweede $11 \mathrm{jn}$ warvan de hulsartis naax wij aannemen op de hoogte is gesteld (onder meer via specialistenbrieven).

Rapportage vam de onderzoeksbevindingen naar anleiding van de hypothesen, komt aan de orde in de deelparagrafen 9.2 .1 en 9.2 .2 (probleemlijat) en in paragraaf 9.3 (comtactfrequentie).

In de overige deelparagrafen rapporteren we het explorerend gedeelte van het praktijkonderzoek:

- deelparagraaf 9.2 .3 behandelt de verhouding actieve/niet actieve problemen onder werkenden en niet werkenden;

- de verdeling van problemen over de ICPC-componenten en hoofdstukken wordt respectievelijk in 9.2 .4 en 9.2 .5 beschreven; 
- in deelparagraaf 9.2.6 combineren we de gegevens van 9.2 .4 en 9.2.5. Dit explorerend gedeelte is toegevoegd om eventuele verschillen in de aard van de problemen tussen werkenden en niet werkenden op te sporen. Inmers:

- gegevens over de verhouding actieve/inactieve problemen verschaffen ons de mogelijkheid na te gaan of al dan niet werken hiermee samenhangt;

- gegevens aangaande de verdeling van problemen over ICPC-componenten kunnen ons inzicht verschaffen in de vraag of niet werken meer samenhangt met klacht- of symptoomgebonden problemen (component 1 ) dan met diagnosegebonden problemen (component 7 );

- gegevens over de verdeling van problemen over ICPC-hoofdstukken stellen ons in stat uitspraken te doen over de vraag of het al dan niet werken samenhangt met specifieke problemen (orgaan-, systeengebonden en psychosociale problemen).

We realfseren ons dat de informatie uit het explorerend gedeelte verder reikt dan de primaire doelstelling van dit hoofdstuk, namelijk de vergelijking van zelfrapportage met rapportage door huisartisen. Gezien de scharse literatuur over nlet werken en gezondheid binnen het vakgebied huisartsgeneeskunde is een dergelijke exploratie alleszins de moeite ward.

Zoals in hoofdstuk 5 beschreven, hebben we in het deelanderzoek prec1sie matching toegepast. Bij elke niet werkende is een werkende gezocht die overeenkomt in achtergrondkenmerken. Hoewel de gematchte arbeldsongeschikten, werklozen en vervroegd gepensioneerden, wat deze kenmerken betreft, overeenkomen met de respectievelijke totale categorieén waruit zij geselecteerd zijn, zijn we toch nog nagegaan of per categorie gematchten en niet gematchten onderlinge verschilien bestaan in het antal problemen en de contactfrequentie met de hulsarts. Dit bleek niet het geval.

We hebben de gematchte niet werkenden en werkenden ook nog gecontroleerd op verzekeringsvorm; ook op deze variabele bleken zij onderling niet te verschillen. 
9.2 De probleemil jot

Twee typen problemen hebben we butten de analyse gelaten, namelijk appendictits en vasectorie. De artsen verschilden van mening of deze relevant zijn voor de probleemlijgt. Daarom hadden somigen deze problemen wel en anderen ze niet vermeld.

9.2.1 Verdeling naar wel of niet aanwezig $z i j n$ van problemen

Tabel 9.1 geeft een overzicht van de aan- en afwezigheld van problemen. Steeds vermelden we de gegevens van de gematchte niet werkenden en werkenden. In de tabellen korten we de term werkenden af met "WE".

Tabel 9.1 Verdeling naar het wel of niet aanwezig zijn van problemen ander de gematchte categorieën niet werkende en werkende manuen $(\%)$.

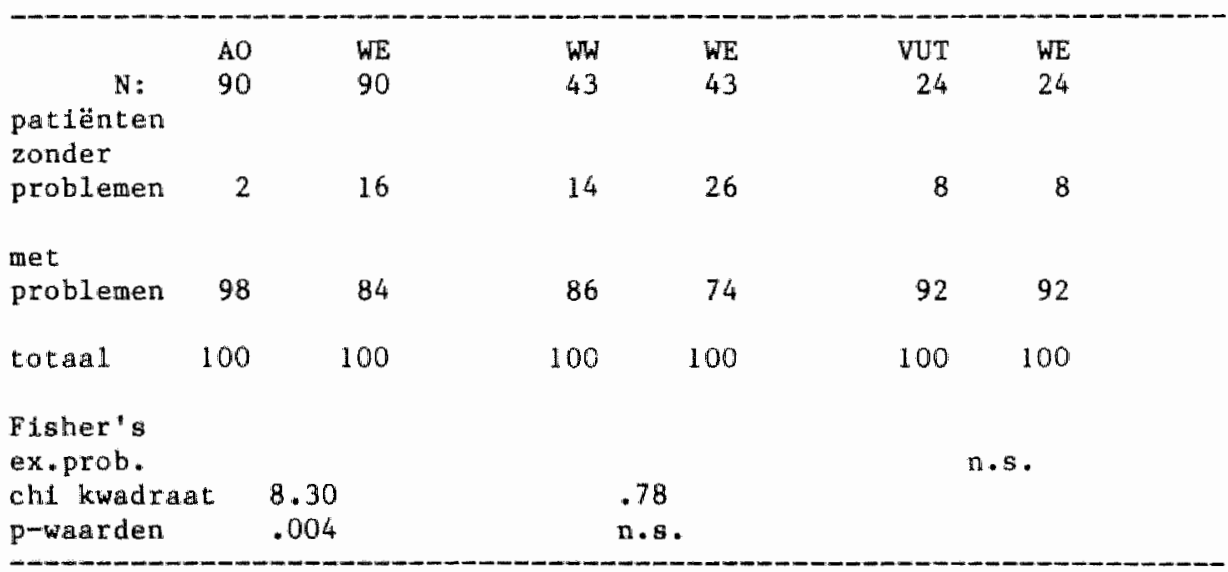

Uit de vermelde resultaten kunnen we, mede gelet op de toetsingsresultaten, het volgende concluderen:

- onder 由lle categorleën hebben de meeste mensen problemen;

- onder arbeidsongeschikten komen meer mensen met problemen voor dan onder werkenden;

- werklozen en vervroegd gepensioneerden verschillen in dit opzicht niet van werkenden. 
9.2.2 Verdeling naar aatallen problemen

In deze paragraal gaan we na in hoeverre niet werkenden van werkenden verschillen in antal problemen. Voor de volledigheid vermelden we eveneens cijfers inzake gemiddelden, standaarddeviatie en range. Toetsing gebeurt op basis van de mediaan.

Tabel 9.2 Enkele kengetallen betreffende aantal problemen van gematchte categorieën niet werkende en werkende mannen.

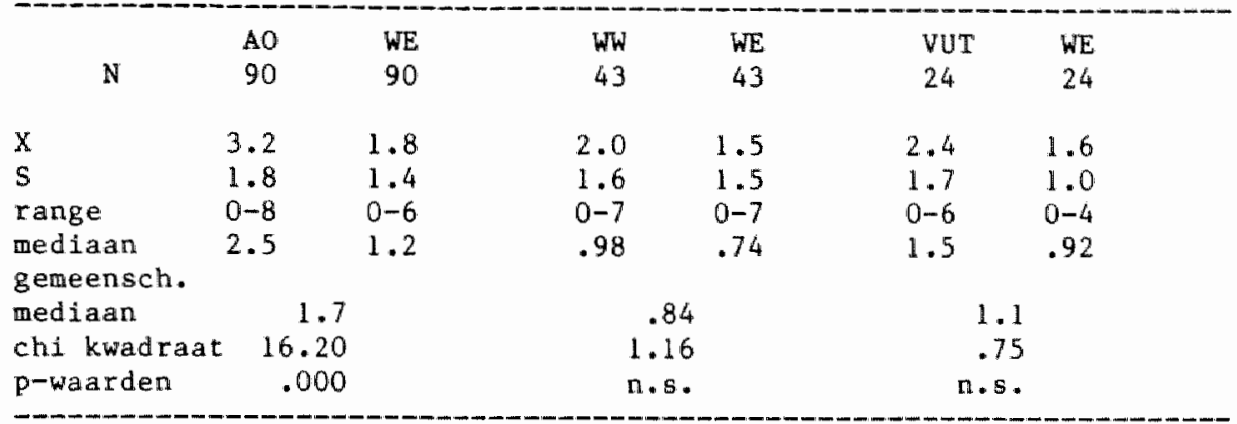

Toetsen we de verschillen op basis van de mediaan dan blijkt het volgende:

- arbeidsongeschikten hebben meer problemen dan werkenden;

- werklazen en vervraegd gepensioneerden verschillen niet van werkenden.

9.2.3 De verhouding tussen actieve en inactieve problemen

In het eerste gedeelte van het explorerend praktijk onderzoek geven we de verhouding tussen actieve en niet actieve problemen weer.

Teneinde vast te stellen of niet werkenden verschillen van werkenden in de verhouding tussen actieve en inactieve problemen geven we een overzicht in tabelvorm. 
Tabel 9.3 Verdeling problemen nat actleve en inactleve status, gedifferentleerd naar gematchte niet werkende en werkende mannen $(\%)$.

\begin{tabular}{|c|c|c|c|c|c|c|}
\hline & $\mathrm{AO}$ & $W E$ & WW & $W E$ & VUT & WE \\
\hline \multicolumn{7}{|l|}{ M pro- } \\
\hline blemen & $288 * *$ & $163^{*}$ & 88 & $61^{* *}$ & 57 & 38 \\
\hline \multicolumn{7}{|l|}{ actieve } \\
\hline $\begin{array}{l}\text { status } \\
\text { inact leve }\end{array}$ & 45 & 40 & 42 & 31 & 28 & 34 \\
\hline gtatus & 55 & 60 & 58 & 69 & 72 & 66 \\
\hline totaal & \multicolumn{2}{|c|}{$100 \%$} & \multicolumn{2}{|c|}{$100 \%$} & \multicolumn{2}{|c|}{$100 \%$} \\
\hline N pat. & \multirow{2}{*}{\multicolumn{2}{|c|}{.74}} & 43 & 43 & 24 & 24 \\
\hline chi kwadraat & & & \multicolumn{2}{|c|}{1.80} & \multicolumn{2}{|c|}{.68} \\
\hline p-waarden & $\mathrm{n}$. & & & & & \\
\hline
\end{tabular}

* : exclusief 1 probleem warvan status onbekend is

** : exclusief 2 problemen warvan status onbekend is

U1t tabel 9.3 kunnen we aflezen dat niet werkenden en werkenden niet verschillen in de verdeling van de problemen naar actieve en inactieve status.

\subsubsection{Verdeling van problemen naar componenten}

De instructies van de probleemlijst zijn zodanig dat alle problemen in component 1 (klachten en symptomen) of component 7 (vaststaande diagnosen) geplaatst worden. De vraag wordt dan hoe de verdeling over deze twee rubrieken $1 \mathrm{~s}$. In tabel 9.4 laten we dit zien.

Tabel 9.4 Verdeling problemen over de ICPC-componenten van gematchte niet werkende en werkende mannen $(\%)$.

\begin{tabular}{|c|c|c|c|c|c|c|}
\hline & $\mathrm{AO}$ & $W E$ & WW & WE & VUT & WE \\
\hline $\begin{array}{l}\text { N pro- } \\
\text { blemen }\end{array}$ & 290 & 164 & 88 & 63 & 57 & 38 \\
\hline $\begin{array}{l}\operatorname{comp} \cdot 1 \\
\text { comp. } 7 \\
\text { totaal }\end{array}$ & $\begin{array}{r}30 \\
70 \\
1\end{array}$ & $\begin{array}{l}31 \\
69\end{array}$ & $\begin{array}{r}32 \\
68 \\
1\end{array}$ & $\begin{array}{l}29 \\
71\end{array}$ & $\begin{array}{l}23 \\
77 \\
10\end{array}$ & $\begin{array}{l}26 \\
74\end{array}$ \\
\hline $\begin{array}{l}\text { N pat. } \\
\text { chi } \\
\text { kwadraat } \\
\text { p-waarden }\end{array}$ & 90 & 90 & 43 & 43 & $\mathrm{n}$ & 24 \\
\hline
\end{tabular}


Duidelijk komt naar voren dat in alle categorieen het merendeel der problemen onder component 7 valt. Dit houdt in dat bij werkenden en niet werkenden het merendeel der problemen een diagnostisch etiket gekregen heeft. Circa $30 \%$ heeft een etiket op klacht- of symptoomniveau, hetgeen wil zeggen dat de huisarts geen of onvoldoende aanwizingen kon vinden voor een verantwoorde diagnose. Gezien deze verde1 ing verbaast het ons niet dat de toetsingsuitslagen geen significante verschillen tussen de gematchte niet werkenden en werkenden laten zien.

\subsubsection{Verdeling van problemen naar ICPC hoofdstukken}

De volgende vraag waarover we ons buigen is of niet werkenden en werkenden onderling verschillen in localisatie van de problemen, overeenkomstig de hoofdstukken van de ICPC.

De analyse-eenheid wordt gevormd door de patiënt met problemen. Dit betekent dat we alléén erop letten of de patiēnt op specifleke hoofdstukken scoort, afgezien van de frequentie.

Omdat de problemen nogal ongelijk over de hoofdstukken verdeeld zijn, beperken we ons bij de beantwoording van vorengestelde vraag tot de hoofdstukken die het meest frequent gescoord zijn én hoofdstukken die, gelet op de literatuur, betekenis hebben in het kader van niet werken. Woor een aanzienlijk gedeelte vallen de hoofdstukken die vanuit beide gezichtspunten in aanmerking komen, samen. Twee hoofidsukken blijven ulteraard bulten beschouwing, namelijk W (zwangerschap, geboorte en gezinsplanning) en $X$ (vrowwelijk gential). Hoofdstuk W blifft buiten beschouwing omdat gezinsplanning geen gezondheldsprobleem in engere betekenis is én omdat de hoofdstukonderdelen "zwangerschap en geboor$t^{\text {th }}$ bij mannen uiteraard buiten de orde zijn. (overigens blijkt, zoals verwacht mocht worden, geen enkel probleem in beide hoofdstukken gescoord te $z i j n)$.

De meest frequent gescoorde hoofdstukken zifn de volgende: L (loconotorisch), K (hart en vaat), $\mathrm{E}$ (psychologisch), D (spijsvertering), $\mathbb{R}$ (resplratoir) en $T$ (metabool, endocrien). In de literatur inzake de oorzak van afkeuring van arbeidsongeschikten worden, zoals vermeld in 
hoofdstuk 3, vooral genoemd: psycholagische problemen (P), locomotorische problemen (L) en hart-en vaatziekten ( $K$ ). In de internationale 11teratuur (zie eveneens hoofdstuk 3) inzake zlekten die het gevolg van werkloosheld kunnen $z \mathfrak{H} f n_{\text {, worden }}$ genoemd: ziekten van hart en bloedvaten $(K)$, hoge bloeddruk $(K)$, psychosociale problemen ( $P$ en $Z$ ). Samenvattend betekent $d t t$ dat we de volgende hoofdstukken in de onderlinge vergelijking opnemen: $D, K, L, P, R, T$ en $Z$. Dit houdt in dat tien van de zeventien hoofdstukken bulten beschouwing blijven, name11jk A (algemeen), B (bloedvormende organen), E (ogen), H (oren), N (neurologisch), S (huid), U (urinewegen), W (zwangerschap, geboorte en gezinsplanning), $X$ (vrouwelijk genitaal) en $y$ (mannelijk genitaal).

We geven de vergelijking weer van arbeidsongeschikten en werkenden op basis van de in hoofdstukken ondergebrachte problemen. Omdat werklozen en vervroegd gepensioneerden niet van werkenden verschillen in de verdeling van gezondheldsproblemen over de ICPC hoofdstukken, hebben we hen niet in de tabel opgenomen.

Tabel 9.5 Verdeling van de gezondheldsproblemen van gematchte arbeidsongeschikte en werkende mannen over zeven ICPC hoofdstukken.

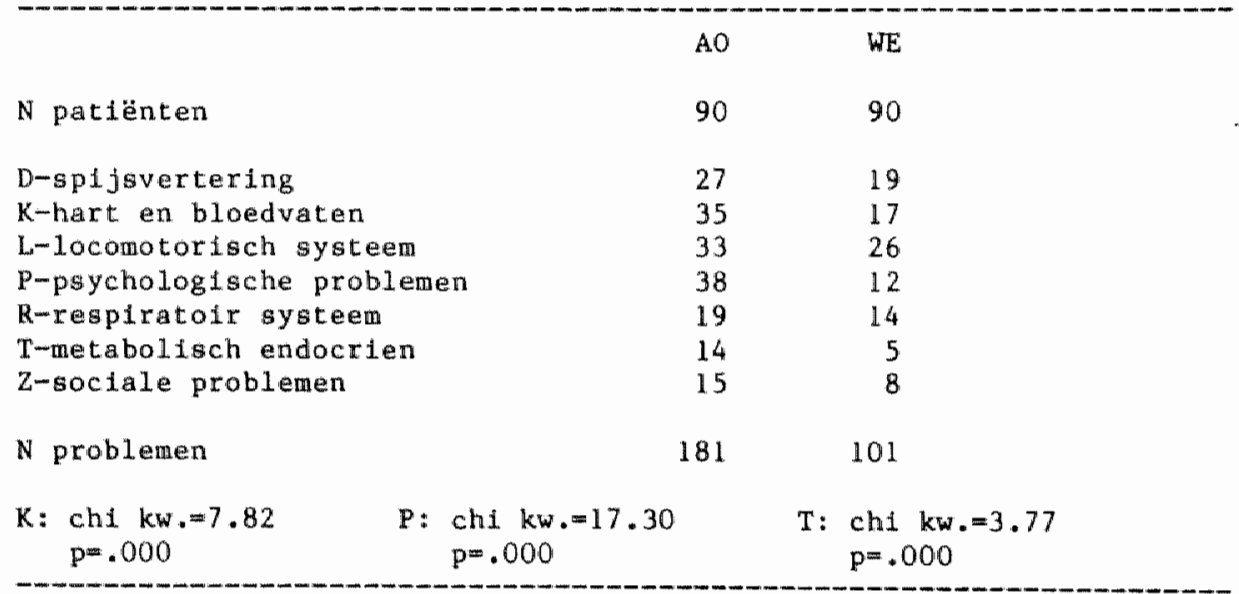

Toetsing van de onderlinge verschillen makt düidelijk dat de categorie arbeidsongeschikten vergeleken met werkenden mér mensen omvat met hart- en vastproblemen, psychologische en metabole problemen. 
9.2.6 Verdeling van actieve en inactieve problemen naar ICPC hoofdstukken

In deze paragraaf komt de verdeling van actieve en niet actieve problemen over de afzonderlijke hoofdstukken aan de orde. Eerder, in paragraaf 9.2 .3 hebben we geconstateerd dat over alle hoofdstukken gezamenlijk, miet werkenden en werkenden niet verschillen.

In deze deelparagraaf beperken we ons tot rapportage van bevindingen van de eerder gekozen zeven hoofdstukken.

Tussen arbeidsongeschikten en gematchte werkenden vinden we slechts één verschil: onder werkenden hebben problemen in hoofdstuk $Z$ (sociaal) vaker een actief karakter dan onder arbeldsongeschikten ( $63 \%$ versus $25 \%$ ). Tussen werklozen en vervraegd gepensioneerden enerzijds en de met hen gematchte werkenden anderzijds vinden we geen verschil1en.

9.2.7. Een inhoudelijke vergelijking van psychosociale problemen van niet werkenden en werkenden

Omdat psychosociale problemen onder gedwongen niet werkenden een actueel thema vormen in de wetenschappelijke literatur en in de opiniebladen, achten we het van belang in te gaan op de vraag of arbeidsongeschikten en werklozen van de met hen gematchte werkenden verschillen in spectfieke problemen zoals deze door de bulsarts zijn genoteerd.

De problemen hebben we geinventarlseerd aan de hand van de af zonderlijke ICPC codes, de daarbij behorende vaste tekst en de door hullartsen eventueel toegevoegde vrije tekst. Zoals de titel wan deze deelparagraaf al aangeeft, nemen we de psychologische en soclale problemen gecombineerd in de vergelijking tussen niet werkenden en werkenden op.

In tabel 9.6 geven we een iahoudel1jk overzicht van de problemen wan arbeldsongeschikten en gematchte werkenden. 


\begin{tabular}{|c|c|c|c|c|}
\hline \multirow[b]{2}{*}{ 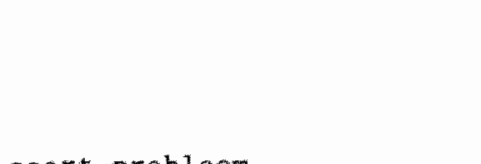 } & \multicolumn{2}{|c|}{$\begin{array}{l}\text { arbeldsonge- } \\
\text { schikten }\end{array}$} & \multicolumn{2}{|c|}{ werkenden } \\
\hline & $\mathrm{abs}$ & $\%$ & $a b s$ & $\%$ \\
\hline - psycho-somatisch & 10 & 16 & 2 & 9 \\
\hline - (vroegere) werkproblemen & 10 & 16 & 4 & 17 \\
\hline - nerveus, angst, gespannen & 9 & 14 & 5 & 22 \\
\hline - depresslef & 8 & 12 & 0 & 0 \\
\hline - misbruik alcohol & 8 & 12 & 3 & 13 \\
\hline - relatieproblemen partner & 5 & 8 & 4 & 17 \\
\hline - misbrulk tabak & 4 & 3 & 2 & 9 \\
\hline - versilaving medicjjnen & 3 & 5 & 1 & 4 \\
\hline - anders & 6 & 10 & 2 & 9 \\
\hline totaa 1 & 63 & 100 & 23 & 100 \\
\hline
\end{tabular}

U1t tabel 9.6 kunnen we afleiden dat de meeste psychosociale problemen verhoudingsgewijs even valk voorkomen onder arbeidsongeschikten als onder gematchte werkenden. Onder voorbehoud van de kleine aantallen kunnen we concluderen dat het erop lijkt dat bij arbeidsongeschikten. vergeleken met werkenden de volgende problemen vaker voorkomen: psycho-sonatische problemen en depressiviteit.

Vermeldenswaard is dat onder arbeidsongeschikten én keer de cade z6: "probleem in verband met werkloosheid" in de probleemlijst voorkomt. In de hoofdstukken $\mathrm{P}$ en $\mathrm{Z}$ wordt "arbeidsongeschikt of WAO" nog vier keer vermeld in de vrije tekst, gekoppeld aan de volgende omschrijvingen:

- "nerveus/angst/gespannen"; het probleemcluster blijkt tot arbeldsongeschiktheid geleid te hebben (tweemal);

- met het hiervoor genoemde probleem; zonder nadere toelichting (énmat 1);

- overspanning op het werk, welke weer voortvloeit uit vroegere traumatische oorlogservaringen; deze heeft tot "WAO" geleid (Énmaal).

Mede ondat arbeidsongeschiktheld weinig in combinatie met omschrijvingen uit de hoofdstukken $P$ en $Z$ genoemd is, zijn we nagegaan hoe vaak 
deze term in verband met andere hoofdstukken vermeld is. "Arbeidsongeschiktheid" bleek nog vier keer voor te komen, namelijk als vrije tekst achter respectievelijk: spondylolisthesls, rugpijn (lumbal en thoracaa1) met ultstraling, HNP-rugsymptomen/klachten $(2 \mathrm{x})$.

Arbeidsongeschiktheid is al bij al bij 9 van de betreffende 90 patienten vermeld, warvan acht keer samenhangend met een ander probleem.

Gelet op het kleine aantal psychosociale problemen onder werklozen en werkenden en de grote diversiteit kunnen we op basis hiervan geen conclusies trekken.

De code 26 "probleem met werkloosheid" werd bij geen der werklozen in de probleemlijst aangekrulst. In de vrije tekst komt onder werklozen éên keer de toelichting "geen werk, thuissituatie" voor, als enige vrije tekst b1j probleem P2 "acute stress, verstoring psychisch evenwicht situatief".

\subsection{Contactregistratie huisarts patiënt}

In deze paragraaf bespreken we de contactfrequentie tussen hulsarts en patiënt over 1986 .

In tabel 9.7 geven we enkele kengetallen betreffende de gematchte niet werkenden en werkenden.

Tabel 9.7 Enkele kengetallen betreffende contacten hulsarts patient van gematchte categorleën nlet werkende en werkende mannen.

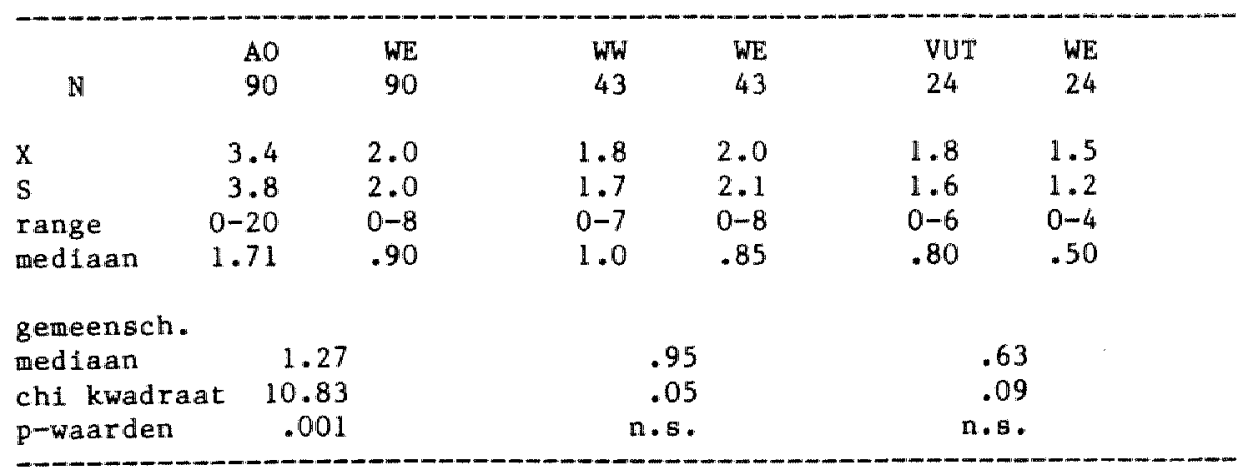


Tabel 9.7 leert ons dat:

- arbeidsongeschlkten waker contact met de hulsarts hebben dan werkender,

- werklozen en vervraegd gepensioneerden in dit opzicht niet van werkenden verschillen.

\subsection{Conclusies en samenvatting}

Omdat in de conclusies de nadruk 1 igt op het toetsen van hypothesen, zullen we eerst de voor dit hoofdstuk relevante hypothese herhalen: zelfrapportage over gezondheld van niet werkende en werkende mannen komt overeen met rapportage door huisartsen aan de hand van medische dossiers.

We hebben gezien dat ten behoeve van deze toetsing gezondheid aan de hand van twee indicatoren gemeten is, te weten het antal met behulp van de ICPC lijst vastgestelde problemen en het aantal arts-patiënt contacten over ến jaar.

In de analyse hebben we ons beperkt tot een onderlinge vergelijking. van elk der niet werkende categorieën met werkenden. De wijze waarop we deze wergelijking uitgewoerd hebben, laat ook uitspraken toe over verschillen en overeenkomsten tussen de drie categorieën onderling. Bovenvermelde hypothese blijkt bevestigd te worden, zaals we hierna zullen zien. We zullen achtereenvolgens de conclusies inzake arbeidsongeschikten, werklozen en vervroegd gepensioneerden bespreken.

Arbeldsongeschikten blijken de enlge categorie te vormen warin mér mensen met problemen voorkomen dan onder werkenden, daarnaast blijken arbeidsongeschikten meer problemen te hebben.

We concluderen derhalve dat de hypothese wat betreft arbeldsongeschikten en voorzover getoetst op geleide van de eerste indicator bevestigd wordt.

Voor werkenden en niet werkenden geldt dat de problemen overwegend op component zeven gescoord zijn. Dit houdt in dat de problemen van alle categorleẹn merendeels op het diagnostisch niveau gelabeld zijn en in de minderheid der gevallen op klacht-/symptoom-niveau. 
Wanneer de patiënten met problemen als analyse-eenheid nemen dan constateren we onder arbeldsongeschikten mér mensen met hart- en vaatproblemen, psychologische en metabole problemen dan onder werkenden.

Vervroegd gepensioneerden en werklozen verschillen niet van werkenden. Naar verdeling van problemen in actieve en niet actieve status verschillen niet werkenden en werkenden niet. Bij de meest frequent gecodeerde hoofdstukken afzonderlijk zien we nagenoeg hetzelfde beeld. De enige uitzondering betreft hoofdstuk $Z$ (sociale problemen): arbeidsongeschikten hebben vergeleken met werkenden minder vaak actleve sociale problemen.

Over het laatste aandachtspunt inzake psychosaciale problemen (hoofdstuk $P$ en $Z$ gezamenlijk) het volgende: wanneer we de specifieke problemen onder de hoofdstukken $P$ en $Z$ onder de loep nemen, valt op dat vooral psycho-somatische problemen en depressiviteit vaker onder arbeldsongeschikten genoemd worden dan onder werkenden. Opvallend is echter dat deze problemen een inactief karakter hebben.

Letten we op de tweede indicator (doktersbezoek), dan blifkt de hypothese eveneens bevestigd te worden.

Het voorgaande impliceert dat de door huisartsen vastgestelde gezondheid van arbeidsongeschikten en vergelijkbare werkenden op populatie niveau niet verschilt van de door overeenkomstige categorieën zelf gerapporteerde gezondheld.

De hypothese dat de door huisartsen vastgestelde gezondheid van werklozen en verwroegd gepensioneerden ên de met deze groepen vergelijkbare werkenden niet afwljkt van de door overeenkomstige categorleën werkenden gerapporteerde gezondheld, wordt nagenoeg geheel bevestigd. Er is derhalve geen reden te veronderstellen dat er sprake 1 s van "cognitieve trucage".

Omdat we de afzonderlijke nlet werkende categorieën steeds met werkenden vergeleken hebben, mogen we op basis van de bevindingen hieromtrent ook concluderen dat arbeldsongeschikten een slechtere gezondheld hebben dan werklozen en vervroegd gepensioneerden. 
We gluten deze paragrataf af met de conclusie dat huisartsen klaarblijkelijk arbeldsongeschikt en werkloos zijn, nawwelijks als een psychosoctal probleem beschouwen dat dusdanige andacht vragt dat het op de probleemlijst vermeld wordt. 


\section{Consistentie van de Gezondheidsmeting}

\subsection{Inlelding}

Met de voorgaande hoofdstukken van deel I zouden we het onderwerp "gezondheid" als afgesloten kunnen beschouwen.

Omdat "gezondheid" de meest centrale varfabele van dit onderzoek is, hebben we ons echter afgevraagd hoe consistent de in hoofdstuk 8 gerapporteerde gezondheidsprofielen van de afzonderlijke categorieën z.i ja.

Om hierover tot een uitspraak te kunnen komen hebben we twee wegen bewandeld.

De eerste betreft een herhaling van de gezondheldsmeting van 1983 voor de populatie die in 1981 in het panel onderzocht is. Verondersteld mag worden dat de gegevens van 1983 niet tot belangrijk andere resultaten hebben geleid dan die van 1981. Ondat de populatie van 1981 slechts gedeeltelijk dezelfde respondenten omvat als die van 1983 - zie hoofdstuk 5 -, mogen we des te meer warde hechten aan een overeenkomstige uitslag. Ondat de gezondheidsmeting van 1981 reeds eerder door anderen is gepubliceerd, zullen we volstaan met dit onderzoek aan te halen. Paragraaf 10.2 is hierwoor gereserveerd.

De tweede weg is die warbif we via een andere benadering dé gegevens van 1983 opnleuw analyseren. We gaan hierbij ult van de scores op alle gezondheidsvariabelen gezamenlijk. Op deze wijze proberen we op basis van een vifftal later te noemen varlabelen de respondenten in horogene groepen in te delen. Vervolgens zullen we toetsen in hoeverre de onderscheiden categorleën niet werkenden in verband gebracht kunnen worden met deze homogene gezondheldsgroepen. De hieruit resulterende proflelen vergelljken we met die van hoofdstuk 8 .

om tot homogene groepen te komen hebben we gebrulk gemaakt van de 
simliartheitsmatrix van Gower. Zoals vermeld in hoofdstuk 5 houdt deze methode in dat respondenten in een matrix gegroepeerd worden op basis van gelljke scores op de afzonderijjke variabelen. Hierbij zijn we uitgegaan van de indelling van respondenten op de kwartielen. Respondenten met similariteit of gelljkenis wan éen worden eerst samengenomen. "Afkappen" gebeurt zodra er sprake is van een "natuurlijk breukpunt" in de afname van de gelijkenis, daarbij rekening houdend met clusters die voldoende groot zijn. De overeenkomsten tussen respondenten die in de matrix geclusterd zijn worden vastgesteld volgens de "complete Iinkage" methode (volgens BMDP). We hebben woor "Gower" gekozen omdat deze methode voorzover ons bekend, de enige is waarbij gebrulk gemakk kan worden van coëfficiënten tussen variabelen van verschillende orde of meetniveau. De resultaten van deze clusteranalyse worden in paragraaf 10.3 gerapporteerd.

De werdeling van niet werkenden en werkenden over de onderscheiden gezondheidsclusters komt aan de orde in paragraaf 10.4 . We zullen vooral aandacht besteden aan de vraag welk gedeelte van de onderscheiden categorieën niet werkenden en werkenden tot de gezonden en welk gedeelte tot de zieken behoort.

10.2 Gezondheid in 1981

Aan de hand wan het Nederland Oke material van 1981 hebben onderzoekers de volgende drie door hen geformuleerde stellingen getoetst (Philipsen, Halfens, 1983).

1 Arbeldsongeschlkten hebben een beduidend slechtere gezondheid dan werkenden;

2 Werklozen hebben geen slechtere gezondheid dan werkenden;

3 Mogeligk bestat binnen de arbeidsongeschikten een definieerbare categorie mensen van wie de gezondheid niet afwijkt van werklozen, en dus ook niet van werkenden.

Hoewel vervroegd gepensloneerden ook in het onderzoek betrokken waren, zijn er geen stellingen over deze categorle geformuleerd. De reden hierwor is dat destijds over hen in de Nederlandse situatie nauwe$11 \mathrm{jks}$ iets bekend was. 
Howel de populatieomschrijving in aazienlijke mate overeenkomt met die van ons in 1983, zijn er twee verschilpunten te constateren:

1 het onderzoek van 1981 omvat allến gehuwde mannen; in ons onderzoek zijn weliswaar de meeste mannen gehuwd, maar ongehuwden komen ook voor:

2 onder de arbeidsongeschikten van $1981 \mathrm{zijn}$ ook respondenten begrepen die langdurig ziek zifn, zonder dat ze onder de WAO/AAW of het ABP-invaliditeitspensioen vallen.

In 1981 omvatte de totale populatie gehuwde niet werkende mannen 190 respondenten, te weten 144 arbeldsongeschikten, 20 werklozen en 26 vervroegd gepensioneerden.

Alvorens tot toetsing over te gaan is vanwege gevonden verschilien in achtergrondkenmerken tussen niet werkenden en werkenden precisie-matching toegepast. Deze matching resulteerde in 86 arbeidsongeschikten en werkenden, 20 werklozen en werkenden, 20 vervroegd gepensioneerden en werkenden. Per categorie zijn de niet werkenden en werkenden vergeleken op vier gezondheidsmacen: aan- of afwezigheld van chronische aandoeningen, aantal malen dat men het laatste jaar met een dokter contact had, score op de verkorte VOEG (2l items) en het aantal de laatste maand geslikte medicijnen, die op eigen initiatief aangeschaft z.il jn.

De eerste conclusie van het onderzoek was dat arbeidsongeschikten duidelijk ongezonder zijn dan werkenden, werklozen en vervroegd gepensioneerden.

De tweede conclusie was dat werklozen, vervroegd gepensioneerden en werkenden uitwisselbaar zijn vanuit het gezichtspunt van de gezondheidstoestand.

Genoemde auteurs hebben geen onderzoek gedaan naar de gezondheld van kort- en langdurig niet werkenden. Ook als zij dit overwogen zouden hebben, was dit nllet mogelifk geweest omdat in 1981 niet gevraagd was hoe lang men zonder werk was.

Onder voorbehoud van de lets afwijkende populatie mogen we concluderend stellen dat bij vergelijking het gezondheldsproflel van 1981 niet blijkt af te wijken van dat van 1983 . 


\subsection{Gezondheid als clustervariabele}

De clusteranalyse is toegepast op alle 703 respondenten van de landelijke steekproef in 1983, bestaande uit de eerder beschreven niet werkende en alle werkende wannen. Een klein gedeelte van hen (22) kon nlet lngedeeld worden omdat deze respondenten op ến of meer variabelen niet gescoord hadden.

De gekozen vartabelen komen overeen met die in hoofdstuk 8. Eén variabele, namelijk "zorgen maken over de eigen gezondheid" hebben we in eerste instantie niet in de analyse betrokken, omdat wij deze niet als een gezondheidsvariabele in de strikte betekenis beschouwen.

De voor ons doel geschiktste en best interpreteerbare clusterindeling leverde vler afzonderlijke clusters op.

Het eexste cluster $(N=127)$ wordt gekenmerkt door:

- aanwezigheid van chronische of langdurige aandoeningen (100\%);

- veel doktersbezoek ( $44 \%$ wier keer of meer);

- veel 1 ichamelijke klachten ( $71 \%$ acht klachten of meer);

- een meerderheid met een matige beoordeling van eigen gezondheid $(54 \%)$

- overwegend geen tot weinig medicatie op eigen initiatief ( $84 \%$ geen). Het tweede cluster $(N=151)$ dat evenals het eerste cluster gekenmerkt wordt doar ongezondheid, heeft de wolgende karakteristieken:

- een meerderheid met chronische of langdurige aandoeningen (60\%);

- vee 1 doktersbezoek ( $48 \%$ vier keer of meer);

- weel. 1ichame11jke klachten ( $82 \%$ acht klachten of meer);

- de helft met een matige beoordeling van de eigen gezondheid ( $49 \%$;

- overwegend veel tot zeer veel medicatie op elgen initiatief ( $98 \%$ vee 1);

Het verschil tussen het eerste en tweede cluster is voornamelijk gelegen in het percentage chromische aandoeningen (100 versus 60\%) en de medicatie ( $84 \%$ geen, versus $98 \%$ veel tot zeer veel). Deze twee verschillen brachten ons tot het onderscheld "chronisch ziek" en "zlek" * De meest opvaliende discrepantie tussen chronisch zieken en zieken betreft het nemen van medicijnen op eigen initiatief. Gelet op de overige kenmerken van het tweede cluster mogen we stellen 
dat er mogelijk sprake is van concurrentie wan medicljnen door dokcers voorgeschreven en medicijnen die mensen op eigen gezag aanschaffen en innemen.

Om de veronderstelling over "zorgen ontrent gezondheid" te toetsen, hebben we de variabele "zorgen maken over gezondheid" toch in de verdere analyse betrokken, gerelateerd aan de clustervariabele. Belde variabelen bleken een signiflcante onderlinge relatie te hebben ( $\mathrm{p}=$ .000 ), warbij het tweede cluster de hoogste score bleek te hebben op "zorgen gezondheid".

Het derde cluster $(N=319)$, betiteld als "gezonden" heeft het volgende profiel:

- geheel ontbreken van chronische of langdurige aandoeningen;

- weinig doktersbezoek ( $88 \%$ nul tot drie keer);

- weinig lichamelijke klachten ( $66 \%$ minder dan acht klachten);

- overwegend goede beoordeling van de elgen gezondheld ( $89 \%$ goed tot zeer goed);

- overwegend ontbreken van zelfmedicatie ( $82 \%$ geen).

Gelet op de hiernavolgende kenmerken ontkwam het wierde en laatste cluster $(N=84)$, niet aan de naam "kerngezonden":

- geheel ontbreken van chronische of langdurige aandoeningen;

- zeer weinig doktersbezoek (100\% nul tot drie keer);

- zeer weinig lichamelijke klachten ( $80 \%$ minder dan acht klachten);

- geheel goede beoordeling van de elgen gezondheld ( $100 \%$ zeer goed);

- in rulme meerderheld geen zelfmedicatie (68\% geen).

Genoemde clusters bleken significant van elkaar te verschillen ( $\mathrm{p}=$ .000 ), hetgeen een voorwaarde 1 s om te mogen spreken van onderacheiden clusters. Daarenboven volgen de clusters elkaar zodanig logisch op, dat we mogen spreken van een zekere schaalbaarheld; daarmee 11jkt deze verdeling veeleer een ordinal dan een nominaal karakter te hebben. De vraag die resteert is hoe de niet werkenden en werkenden over deze clusters verdeeld $z 1 j n$. 
10.4 Het gezondhe1dsproflel van werkenden en nlet werkenden

Gegeven de resultaten van de in hoofdsuk 8 gemaakte vergelijking van niet werkenden onderling En wet werkenden, op basis van de afzonder11 jke gezondhetdsvarlabelen, mogen we verwachten dat werkenden, werklozen en vervroegd gepensioneerden vooral in de clusters 3 en 4 zullen voorkomen, en arbeidsongeschikten vooral in de eerste twee clusters. Daarnaast zal het totale cluster ons antwoord geven op de vraag welk gedeelte van de arbeldsongeschikten een goede gezondheld, en welk gedeelte van de overige categorieën een slechte gezondheid heeft. In tabel 10.1 geven we de verdeling weer van niet werkende en werkende manen over de gezondheidsclusters.

Tabel 10.1 Verdeling van niet werkende en werkende mannen over de gezondheidsclusters $(\%)$.

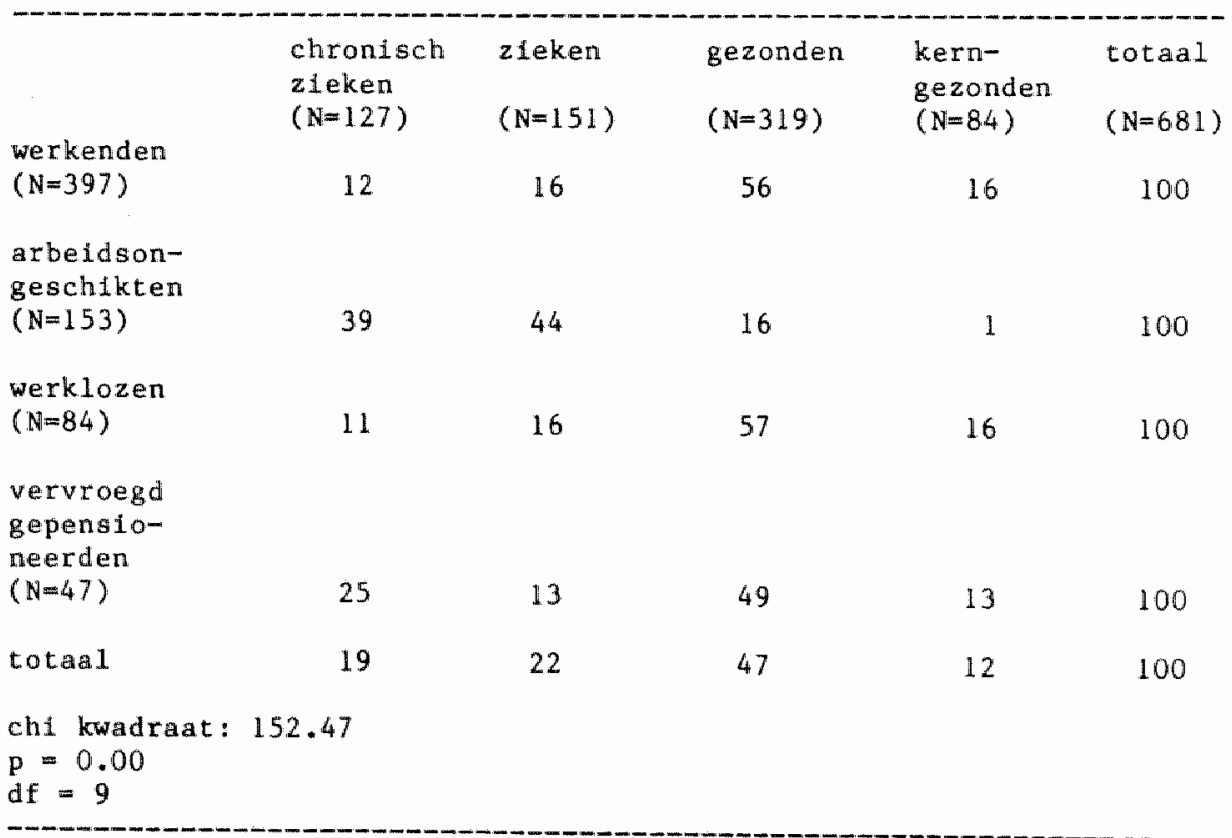

Overeenkomstig onze verwachting blifkt dat:

- arbeldsongeschikten ( $83 \%$ ) merendeels onder beide categorteën zieken vallen; 
- werkenden (72\%) en werklozen (73\%) in rulme meerderheid tot beide categorieën gezonden behoren;

- de meerderheid van de vervroegd gepensioneerden (62\%) eveneens tot de gezonden behoort.

Op het eerste gezicht is het opvallend dat het percentage ongezonden onder de gezond veronderstelde niet werkenden het hoogst is onder de vervroegd gepensioneerden (37\%). Toch hoeft dit ciffer ons niet te verbazen, ook al omdat eerder bleek dat vervroegd gepensioneerden in gezondheid overeenkomen met werkenden. We mogen immers aannemen dat het relatief hoge percentage ongezanden met leeftijd en niet met vervroegd gepensioneerd zijn samenhangt.

Concluderend mogen we stellen dat het gezondheidsprofiel in aanzien1 ljke mate overeenkomit met dat van hoofdstuk 8 .

Gelet op de resultaten van de gecorrigeerde vergelijking uit hoofdstuk 8 én de ongecorrigeerde vergelijklng uit dit hoofdstuk mogen we aannemen dat achtergrondkenmerken en de duur van het niet werken een aan de "werkstatus" ondergeschikte verklaring geven voor verschillen in gezondheid. Nadere analyse zal ons méer informatie geven over het achtergrondsprofiel van de volgende vier naar gezondheid inconsistente sub-populaties uit tabel 10.1 :

- $17 \%$ gezonde arbeldsongeschikten;

$-27 \%$ zieke werklozen;

- $28 \%$ zieke werkenden;

- $37 \%$ zieke vervroegd gepensioneerden;

Vooral de in tabel 10.1 vermelde $17 \%$ gezonden onder de arbeidsongeschikten en $27 \%$ zleken onder de werklozen zijn getallen die ons inziens nadere aandacht vragen. Deze getallen interesseren ons in het bijzonder in het kader van de discussie over de verborgen arbeldsongeschikten onder de werklozen.

op het eerste gezicht 11 jken de $17 \%$ gezonde arbeldsongeschikten verborgen werklozen te zijn. De zleken onder de werklozen wekken het vermoeden dat we met verborgen arbeldsongeschikten te maken hebben. Om tot enige profilering van deze en andere hyervoor vermelde inconsts- 
tente subgroepen te komen zullen we nagaan of zieken zich van gezonden onderschelden, vooral gelet op achtergrondkenmerken en de duur van het nfet werken.

We hebben een btapsgewijze en een niet stapsgewijze discriminantanalyse ultgevoerd, met het gezondheidscluster als afhankelijke variabe1e. Alle door ons geanalyseerde variabelen hebben we hierblj betrokken.

De belangrijkste verklaring voor verschillen in gezondheid leverde de stapsgewljze benadering op met een clusterindeling waarbij de clusters 1 en 2 (zleken) en de clusters 3 en 4 (gezonden) samengenomen $z i j n$. Gecorrigeerd op toeval bleek dat alle variabelen gezamenlijk $46 \%$ van de verschillen in gezondheid verklaarden. De kans om tot de zieken te behoren werd in aflopende mate geconditioneerd door arbeidsongeschiktheld (F-waarde: 183,2), duur niet werken (F-waarde: 112,9) en leeftijd (F-warde: 73,8$)$. Pas daarna volgde een reeks van andere variabelen. Hiermede wordt nogmaals bevestigd dat zowel de gecorrigeerde als de niet gecorrigeerde onderlinge vergelijking van onderscheiden categorieën naar gezondheid tot dezelfde uitslagen leidt: arbeidsongeschikten blijken steeds intrinsiek ongezonder. Duur van niet werken en leeftijd geven een aan de werkstatus aanvullende verklaring voor verschillen in gezondheid. Daarmee is eveneens duidelijk geworden dat burgerlijke staat en sociaal-economische klasse nagenoeg geen rol spelen in de verklaring van verschillen in gezondheid. De duur van niet werken en leeftijd leveren na arbeidsongeschiktheid de belangrijkste verklaring van verschillen in gezondheid.

Met deze wetenschap keren we terug naar tabe1 10.1. Op basis van voorstaande bevindingen mogen we derhalve veronderstellen dat:

1 gezonde arbeidsongeschikten zich van zieke arbeidsongeschikten onderscheiden door een fongere leeftijd en een kortere arbeidsongeschiktheldsduur;

2 zleke werklozen ouder zijn dan gezonde werklozen én langere tijd werkloos zijn;

3 zieke werkenden ouder zijn dan gezonde werkenden;

4 zieke vervroegd gepensioneerden langere tijd zonder werk zijn dan gezonde (verschil in leeftijd is hier niet van toepassing). 
In de tabel 10.2 geven we op basis van het onderscheid ziek-gezond een overzicht van de niet werkende en werkende mannen, gedifferentlëerd naar leeftijd en duur zonder werk. Zleken vormen een samenvoeging van. de eerste twee, gezonden van de latste twee clusters.

Tabel 10.2 Verdeling zieke en gezonde mannen naar werkstatus, gedifferentiëerd naar leeftijd en duur zonder werk $(\%)$.

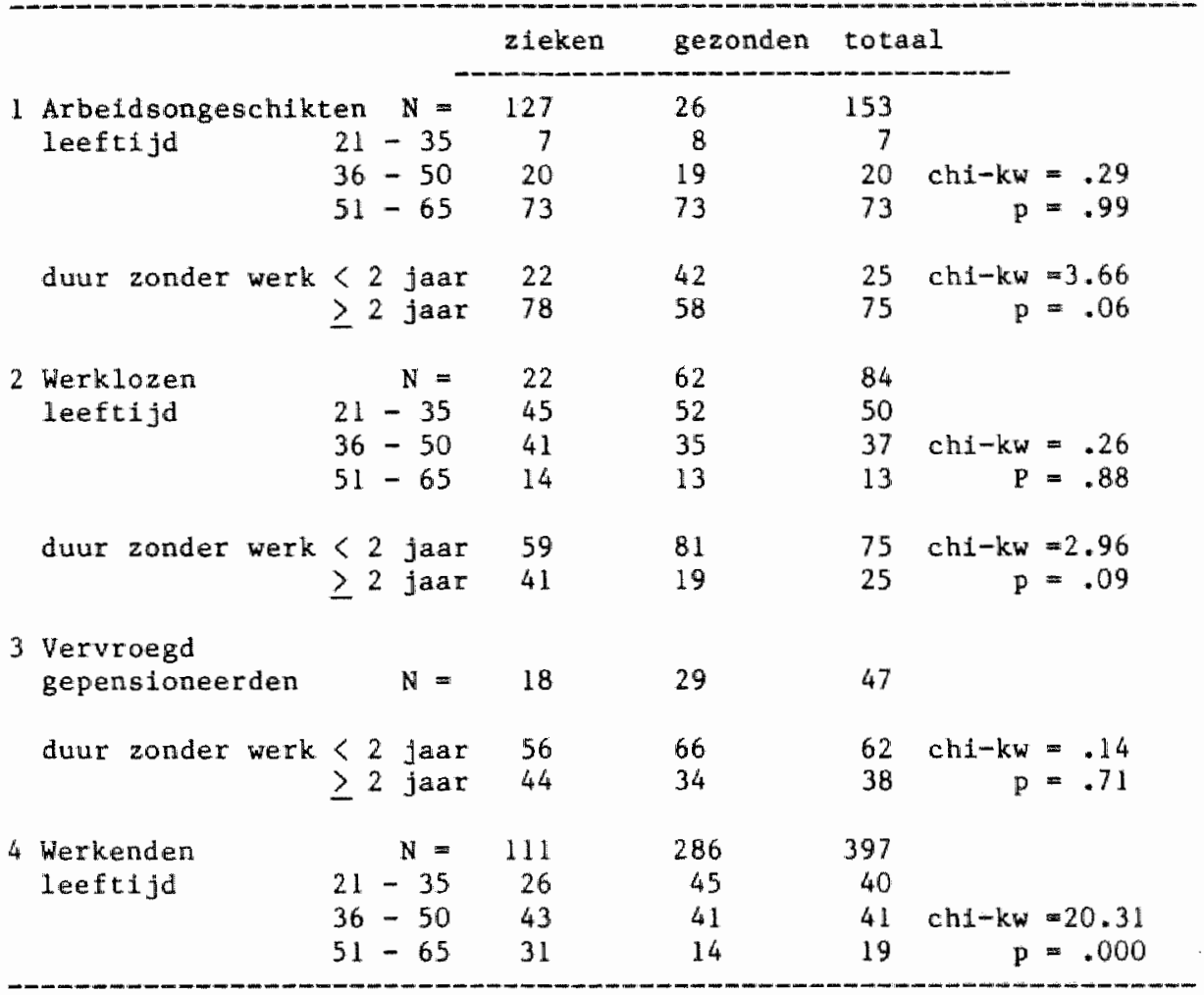

Dat de leeftijdsverdeling onder vervroegd gepenstoneerden ontbreekt, evenals de rubrlek "duur niet werken" onder werkenden, behoeft ons niet te verbazen ondat vervroegd gepensioneerden allen tot de oudste leeftijdscategorle behoren en de rubriek "duur niet werken" voor werkenden uiteraard niet van toepassing í.

De volgende resultaten zijn in overeensteming met de eerder geute veronderstellingen:

- gezonde arbeidsongeschikten vertonen een tendens kortere tijd zonder werk te $z i j n$ dan zieke arbeidsongeschikten; 
- zieke werklozen vertonen een tendens langere tijd zonder werk te zijn dan gezonde werklozen;

- zieke werkenden ziljn ouder dan jonge werkenden.

Contrasterend aan onze veronderstellingen vinden we eveneens dat:

- gezonde arbeldsongeschikten niet in leeftijd verschillen van zieke arbeldsongeschikten;

- zleke werklozen niet in leeftijd verschillen van gezonde werklozen;

- zieke vervroegd gepensioneerden zich niet van gezonde vervroegd gepenstoneerden onderscheiden in de duur dat men zonder werk is.

Het mag op het eerste gezicht opvallend genoemd worden dat we onder werkenden wél en onder arbeidsongeschikten en werklozen géen relatie vinden tussen leeftijd en gezondheld. Voor de arbeidsongeschikten is dit begrifpelijk ondat allen geselecteerd zijn op basis van een slechte gezondheld. Voor de werklozen hebben we geen verklaring. Gezonde en zieke arbeidsongeschikten blijken overigens overwegend ouder dan 51 jaar (respectievelijk $73 \%$ en $72 \%$ ), terwijl gezonde en zieke werklozen overwegend jonger dan 50 jaar blijken (respectievelijk $86 \%$ en $87 \%$ ). overigens blijkt uit verdere elaboratie dat binnen vrijwel alle naar gezondheid gehomogeniseerde deelpopulaties van arbeidsongeschikten en werklozen geen samenhang bestaat tussen leeftijd en duur van het niet werken. De enige ultzondering hierop vormen de zieke arbeidsongeschikten; hier komt naar voren dat ouderen langere tijd zonder werk zijn dan jongeren (chi kwadraat 6.85; $\mathrm{p}=.04$ ). De deelpopulaties gezonde arbeldsongeschikten $(\mathrm{N}=26)$ en zieke werklozen $(\mathrm{N}=23)$ zijn relatief nogal klein om tot uitspraken te komen waraan veel betekenis gegeven kan worden. Overigens hoeft het ons niet te verbazen dat er binnen de gezonde arbeidsongeschikten geen relatie is tussen leeftijd en de duur van het nilet werken: dat het aandeel gezonde langdurig arbeidsongeschlkten niet veel groter is dan dat van de gezonde kortdurig arbeidsongeschikten kan immers zeer wel het gevolg zijn van de relatief snelle reintegratie in het arbeldsproces van de gezonden.

De categorie dle in deze bespreking resteert wordt gevormd door werkenden: de positieve relatie tussen leeftijd en gezondheid duidt op een met het stijgen van leeftijd toenemende verstoring van het evenwicht draaglast-draagkracht. Opzienbarend is deze bevinding niet. Bijna Eén derde van de zieke werkenden is ouder dan 51 jaar; opvallend 
is dat het aandeel binmen de leeftijdscategorle 36-50 jaar groter is, namelijk 4l\%. Het ligt voor de hand te veronderstellen dat dit verschil voortkomt uit afvloeling van ouderen in geval van zlekte vila de arbeidsongeschiktheidswet en mogelijk via de werkloosheidswet.

Niettemin weten we uit de literatuur dat het aantal zieke mensen onder de categorie werkenden aanzienlijk is; dit geldt ook voor het percentage mensen dat ingeval van wlekte blijft doorwerken. In een landelijke steekproef gaf $25 \%$ te kennen "gewoon" doorgewerkt te hebben toen men zich de latste keer ziek voelde.

onder de niet actieven gaf $15 \%$ aan "gewoon" doorgegaan te zijn met de gebruikelijke activiteiten in geval van ziekte (Adriaanse et al, 1981). Eerder al rapporteerde $42 \%$ van de beroepsbevolking boven de 45 jaar bij gezondheidsklachten door te werken (Bramlage, 1962).

Uit een onlangs afgesloten onderzoek onder wAO-intreders komt nat voren dat een gedeelte van hen lange tijd doorwerkte, nadat $z 1 j$ bemerkten dat de gezondheidsklachten de prestaties op het werk negatief bejuvloedden (GMD, 1987). Het percentage zieken onder de werkenden is derhalve niet opzlenbarend.

We dienen wel op te merken dat over onze $28 \%$ zieke werkenden geenszins gesteld is dat zij allen ziek thuls bleven; wel weten we dat we de langdurig zieken onder de werkenden buiten onze werkende populatie gehouden hebben.

\subsection{Conclusies en samenvatting}

Omdat gezondheld de belangrijkste variabele in dit onderzoek 18 ; hebben we ons in dit hoofdstuk gebogen over de consistentle van de bevindingen.

Aan de ene kant hebben we vastgesteld dat in de panelstudie van 1981 de bevindingen overeenkomen met die van 1983 (10.2). Aan de andere kant hebben we ons materiaal nog eens langs een andere weg geanalyseerd, namelijk via clusteranalyse (10.3). In paragraaf 10.4 bespraken we de verdeling van niet werkenden en werkenden over de onderscheiden gezondhefdsclusters. Hierbij viel op dat: 
1 het gezondheidsprofiel, op basis van AwovA met correctie, overeenkomt met dat op basls van clusteranalyse;

2 achtergrondkenmerken en duur niet werken een aan werkstatus ondergeschikte verklaring geven voor verschlllen in gezondheld;

3 de duur wan het niet werken en de leeftijd nd arbeidsongeschiktheid de belangrifkste verklaring geven voor verschillen in gezondheid in onze totale populatie van werkenden en alet werkenden;

4 het percentage gezonden onder de arbeldsongeschikten kletner is dan het percentage zleken onder de werklozen.

onder arbeldsongeschlkten en werklozen bleek gén en onder werkenden. wel een samenhang tussen leeftijd en gezondheid. Onder arbeldsongeschikten en werklazen bleken de langdurig niet werkenden een slechtere gezondheid te hebben dan de kortdurig niet werkenden. 


\section{Conclusies en Discussie}

In dee 1 II is duidelijk geworden dat arbeidsongeschikten een intrinsiek slechtere gezondheid hebben dan werklozen, vervroegd gepensioneerden en werkenden. Tevens komt naar voren dat werklozen, vervroegd gepensioneerden en werkenden vrijwel geheel overeenkomen. De hypothesen blijken grotendeels bevestigd. Twee bevindingen contrasteren met onze verwachtingen: werklozen hebben gến slechtere subjectieve gezondheid dan vervroegd gepensioneerden en werkenden, maar komen met hen overeen.

Onze hypothesen over de gezondheidsopvattingen met betrekking tot de niet werkenden onderling blijken voor meer dan de helft bevestigd te worden. Arbeidsongeschikten blijken, in tegenstelling tot onze veronderstelling niet wan werklozen en vervroegd gepensioneerden te verschillen in het belang dat gezondheid voor hen heeft; evenmin blijken zij een lagere interne oriëntatie te hebben dan werklozen, terwijl zij met vervroegd gepensioneerden overeenkomen. Arbeidsongeschikten blijken wel een hogere oriëntatie op artsen als machtige anderen te hebben dan werklozen.

De hypothesen over de vergelijking van niet werkenden en werkenden onderling worden grotendeels bevestigd. Niet werkenden blijken tevens vaker van werkenden dan van elkaar te verschillen. Opvallend is echter dat arbeidsongeschikten gezondheld niet en vervroegd gepensioneerden gezondheld wêl belangrijker achten dan werkenden. Mogelijk heeft bij vervroegd gepensioneerden de wens een goede gezondheld te behouden mede een rol gespeeld bij het beslult met werken te stoppen. Arbeldsongeschikten onderschelden zich in vergellfking tot de andere categorleën niet werkeaden het meest uitdrukkelijk van werkenden naar gezondheldsopvattingen: vooral de lagere interne orlëntatie en de hogere 
orléntatie op artsen als machtige anderen valt op. Gezien hun afhanke11 jkheid yan het medische circuit is dit niet verwonderlijk.

Gelet op de grote overeenkomst tussen de door niet werkenden gerapporteerde en door hulsartsen vastgestelde gezondheid van niet werkenden en werkenden, mogen we annemen dat er geen reden is om te twijfelen aan de betrouwbaarheld van gezondheidsrapportages van mensen zelf over hun gezondheid. "Cognitleve trucage" onder arbeidsongeschikten en werklozen is niet aangetoond.

Gelet op de algemeen veronderstelde belasting van het gedwongen niet werken En de gezondheidsrisico"s van vooral arbeidsongeschikten, achten we het opvallend dat noch arbeldsongeschikt zijn, noch werkloos zijn als "psychosoctaal probleem" vermeld is op een probleemlijst.

Een belangrijk aandachtspunt betreft de consistentie van de onderzoeksbevindingen over de gerapporteerde gezondheid. Resultaten van 1981 uit dezelfde panelstudie van andere onderzoekers leveren eenzelfde proflel op.

De door ons op een andere wijze dan in hoofdstuk 8 verrichte analyse van gezondheld, namelijk clusteranalyse, bevestigt de uitkomsten van de ANOVA analyse. Daarenboven hebben we gezien dat de duur van het miet werken én leeftijd verschillen in gezondheid mede blijken te verklaren. In hoeverre de duur van het niet werken een oorzaak is van een slechtere gezondheld komt 1 deel IV aan de orde. Vooruitlopend hierop wijzen we erop dat in hoofdstuk 5.3 (tabel 5.3) al naar voren kwam dat de totale populatie-uitval tussen 1981 en 1983 vanwege over11jden onder arbeidsongeschikten en vanwege ziekte onder vervroegd gepensloneerden relatief het grootst is.

Gelet op de door de overheid gehanteerde schatting van $50 \%$ verborgen werklozen onder de arbeldsongeschikten is het percentage gezonde arbeidsongeschikten van $17 \%$ opvallend laag.

Hoewel we ons percentage van 17 niet zonder meer gelifk magen stellen aan het percentage "verborgen werklozen", komt dit getal redelijk overeen met de schatting van $15 \%$ verborgen werklozen van Hermans, Sas en Schaven (1986). Onze eerder uitgesproken veronderstelling dat het 
mexendeel van hen van jonge leeftijd zou zijn, blijkt niet juist. Blijft nog de vraag open in hoeverre de door 17\% der arbeldsongeschikten gerapparteerde "gaede gezondheld" het gevolg is van het - ten gevolge van het wegvallen van betaalde arbeid - herstelde evenwcht draaglast-draagkracht. Vanut dit gezichtspunt zou hun goede gezondheid een voorwaardelijk karakter hebben dat bestat bij de gratie van het niet meer (hoeven) werken.

Daarenboven trof ons dat het percentage zieke werklozen hoger is dan het percentage gezonde arbeidsongeschikten: $27 \mathrm{w}$.

Omdat werklozen in gezondheld met werkenden overeenkomen, kan het percentage van $27 \%$ zieke werklozen ons niet echt verbazen. Zoals zeer waarschijnlijk een aanzienlijk deel der zieke werkenden potentieel arbeidsongeschikt 1 s, zo zou een anzienlijk deel van de zieke werklozen "verborgen arbeidsongeschikt" kunnen zijn.

De kans op relntegratie in het arbeidsproces van zieke werklozen zou nog wel eens kleiner kunnen zijn dan dat van arbeldsongeschikten, gelet op de matregelen die voor de laatste groep wel (Nifhuis en Bullinga, 1987) en voor de eerste groep niet genomen $z 1 j n$. We achten het zeer wel denkbaar dat zieke werklozen een grotere kans op reintegratie hebben, zodra voor hen eenzelfde belleid gevolgd zou worden. Voorzover er sprake is van matschappelijke scheidslijnen in gezondheid blijkt een duidelijke intensieve scheidslijn tussen enerzijds arbeidsongeschikten en anderzijds werklozen, vervroegd gepensioneerden en werkenden.

Wat betreft gezondheidsopvattingen $1 \mathrm{~s}$ er nauwelifks sprake van matschappelijke scheidslijnen. Het meest opvallend is nog de gedeeltelijke scheidslijn tussen arbeldsongeschikten en werkenden; arbeidsongeschikten hebben een lagere interne en een hogere externe oriëntatie dan werkenden. 


\section{Deel III: Leefwijze}

12. Inleiding Deel III

13. Riskante Gewoonten en het Oordeel over de eigen Leefwijze

14. Participatie

15. Conclusies en Discussie 



\section{Inleiding Deel III}

In dit gedeelte toetsen we de in het vierde hoofdstuk geformuleerde hypothesen over riskante gewoonten en participatie. In hoofdstuk 13 geven we de resultaten weer inzake gerapporteerde riskante gewoonten en het oordeel over de eigen leefwijze. Over het laststgenoemde onderwerp hebben we geen hypothesen geformuleerd.

De resultaten inzake gerapporteerde particlpatle worden in hoofdstuk 14 weergegeven.

Conform deel II geven we ook hier gecorrigeerde cijfers, hetgeen inhoudt dat we de invloed van de achtergrondkenmerken en de duur van het niet werken uitgeschakeld hebben. Voor een ultgebreidere verantwoording hlervan verwijzen we naar deel I (5.4) en de inleiding van deel II.

Wellicht ten overvloede wijzen we erop dat de resultaten van dit deel ên van deel IV uitsluitend berusten op de gegevens van Nederland Oké uit 1983 . 


\section{Riskante Gewoonten en het Oordeel over de eigen leefwijze}

\subsection{Inletding}

Ook in dit hoofdstuk vergelijken we weer de drie categorieën niet werkende mannen onderling (13.2) én met werkende mannen (13.3). Deze vergelijkingen worden aan de hand van drle maten voor riskant gedrag gemakt, te weten: ontbreken van regelmatige lichaamsbeweging, roken en gebruik van alcoholhoudende dranken. Daarnaast bespreken we het oordeel van de respondenten over hun leefwijze.

Ontbreken van lichaamsbeweging houdt in dat men rapporteert dat er geen sprake is van regelmatige lichaamsbeweging.

Aan het rookgedrag onderscheiden we twee aspecten, namelijk of men rookt en zo ja hoeveel per dag. Waar het de hoeveelheid betreft, hebben we alleen onder de sigaretten en shagrokers de aantallen vastgesteld. Het aantal pijp- en sigarenrokers was dermate klein dat we besloten hebben hilervan de hoeveelheld buiten beschouwing te laten. Het percentage rokers betreft alle mannen die roken, ongeacht de vraag wat $z 1 j$ roken.

We rapporteren eveneens over twee aspecten van het alcoholgebruik, namelijk of men alcoholhoudende dranken gebrulkt en zo ja, hoeveel glazen per week.

Het oordeel over de eigen leefwijze werd door de ondervraagden gegeven aan de hand van een zeven puntsschaal, varlerend van: 1 = zeer gezond, 2 - gezond, 3 = entgszins gezond, en zo verder tot 7 = zeer ongezond. We bespreken ook hier allén de cljfers op basis van de vergelijking. na correctie.

In paragraaf 13.4 geven we de conclusies weer op basis van de hypothesen. Voorts geven we in 13.5 een samenvatting van de bevindingen. 
13.2 Een onderlinge vergelifking van nlet werkenden nar riskante gewoonten en oordeel over de elgen leefwlje

In tabel 13.1 geven we een overzicht van de vergelijking wan de drie categorieën niet werkenden.

Tabel 13.1 Arbeidsongeschikte, werkloze en vervroegd gepensioneerde mannen onderling vergeleken naar riskante gewoonten en oordeel elgen leefwijze (1983).

\begin{tabular}{|c|c|c|c|c|}
\hline & $\begin{array}{c}\text { AO } \\
(1) \\
(N=155)\end{array}$ & $\begin{array}{c}\text { WW } \\
(2) \\
(N=87)\end{array}$ & $\begin{array}{c}V \mathrm{U} \\
(3) \\
(N=48)\end{array}$ & $\begin{array}{l}\text { toetsing } \\
\text { verschilien }\end{array}$ \\
\hline $\begin{array}{l}\text { \% ontbreken } \\
\text { lichaamsbeweging }\end{array}$ & 71 & 47 & 49 & $\begin{array}{l}1 \neq 2 \neq 3^{* *} \\
2 \neq 3 * *\end{array}$ \\
\hline$\%$ rokers & 66 & 70 & 47 & $\begin{array}{l}3 \neq 1,2^{* *} \\
1=2\end{array}$ \\
\hline $\begin{array}{l}\text { gemiddeld aantal siga- } \\
\text { retten per dag (rokers) }\end{array}$ & 18 & 15 & 21 & $\begin{array}{l}3=1,2 \\
1 \neq 2\end{array}$ \\
\hline $\begin{array}{l}\text { \% gebruikers alcohol- } \\
\text { houdende dranken }\end{array}$ & 76 & 85 & 86 & $\begin{array}{l}2 * 1,3 \\
1 \neq 3\end{array} * *$ \\
\hline $\begin{array}{l}\text { gemiddeld aantal glazen } \\
\text { per week (drinkers) }\end{array}$ & 12 & 16 & 13 & \\
\hline $\begin{array}{l}\text { oordeel over de } \\
\text { elgen leefwljze }\end{array}$ & $\begin{array}{l}\text { enigszins } \\
\text { gezond } \\
(2,7)\end{array}$ & $\begin{array}{l}\text { gezond } \\
\qquad(2,3)\end{array}$ & $\begin{array}{l}\text { gezond } \\
(2,1)\end{array}$ & $\begin{array}{l}1 \neq 2,3^{*} \\
2=3\end{array}$ \\
\hline $\begin{array}{l}*: .05<\mathrm{p}<.10 \\
\star *: .01<\mathrm{p}<.05 \\
\star * *: \mathrm{p} \leq .01\end{array}$ & & $1: t$ & ezijdig & etoetst \\
\hline
\end{tabular}

Bij bestudering van tabel 13.1 kunnen we vaststellen dat:

- arbeidsongeschikten duidelijk minder regelmatig lichaamabeweging hebben dan werklozen en vervroegd gepensioneerden: $71 \%$ versus $47 \%$ en 49\%; werklozen en vervroegd gepensioneerden verschillen eveneens onderling;

- van de arbeldsongeschikten en werklozen een aanzienlijk groter aantal rookt dan van de vervroegd gepensioneerden $666 \%$ en $70 \%$ versus 47\%). Arbeidsongeschikten en werklozen verschillen nilet;

- rokers onder vervroegd gepenstoneerden niet verschillen van de overige twee categorleën in de hoeveelheid slgaretten per dag* Arbeidsongeschikte rokers roken wel meer sigaretten dan rokende werklozen; 
- werklozen nlet van de overige twee categorieën verschillen in het percentage dat alcoholhoudende dranken gebrulkt. Van de arbeidsongeschikten drinkt een kleiner gedeelte alcoholhoudende dranken dan van de vervroegd gepensioneerden ( $76 \%$ versus $86 \%$ );

- de "drinkers" onder de drle categorleën verschillen onderling niet in het aantal glazen per week;

- arbeldsongeschikten een minder positief oordeel over de eligen leefwijze hebben dan de overige twee categorieën (enigszins gezond versus gezond); werklozen en vervroegd gepensioneerden komen onderling owereen.

13.3 Een vergelijking naar riskante gewoonten en oordeel over de eigen leefwijze wan werkenden en niet werkenden

In deze paragrat vergelijken we werkenden met arbeidsongeschikten, werklozen en vervroegd gepensloneerden (Tabel 13.2).

Tabe1 13.2 Verschillen/overeenkomsten in riskante gewoonten en oordeel elgen leefwijze tussen werkende $(N=412)$ en niet werkende mannen. (1983)

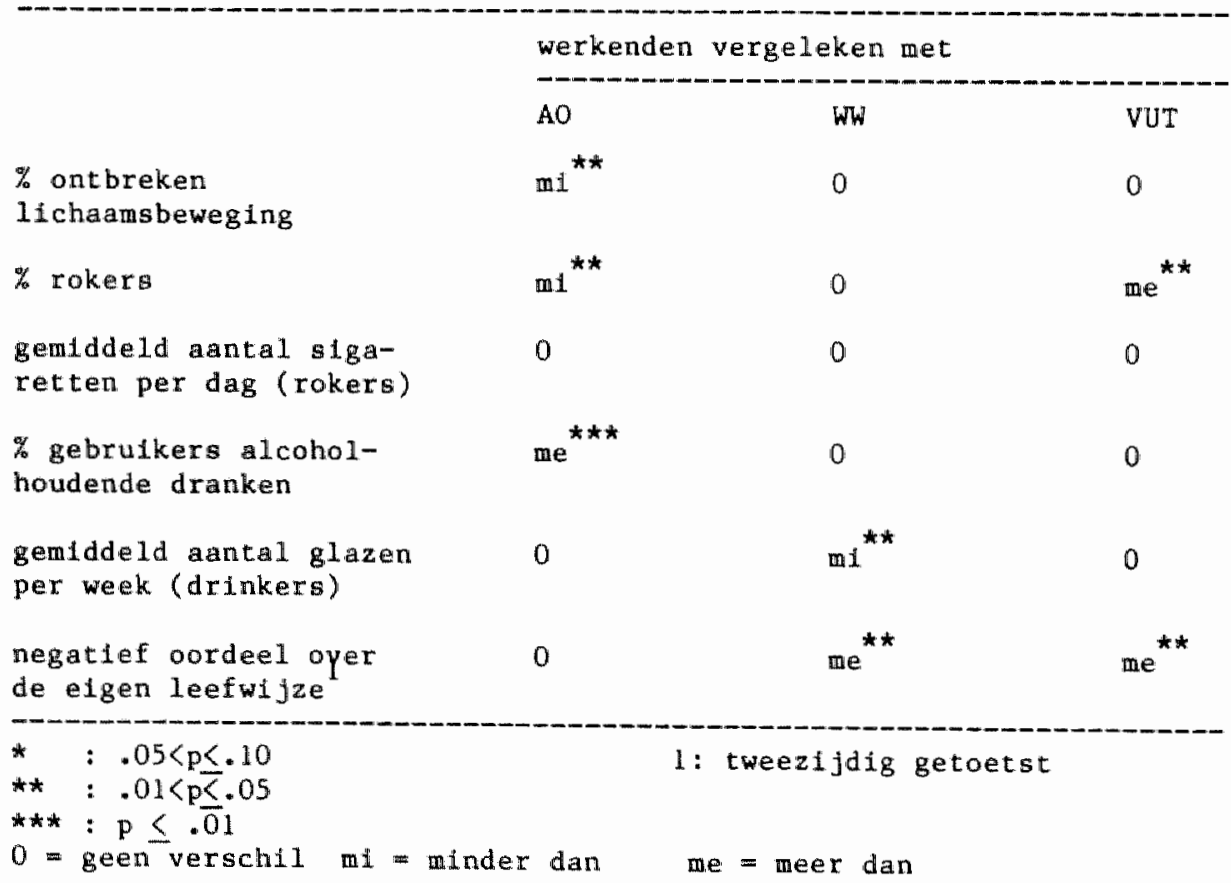


Global bezien valt op dat werkenden zich gedeelcelijk in riskante gewoonten onderscheiden van arbeidsongeschikten en nawelijks verschillen van werklozen en vervroegd gepensioneerden. Wat betreft het oordeel over de eigen leefwijze verschillen werkenden zowel van werklozen als vervroegd gepensioneerden. Wanneer we per variabele werkenden met arbeldsongeschikten vergelijken, zien we het volgende:

- een groter gedeelte van de werkenden heeft regelmatig lichaambeweging ( $49 \%$ versus $38 \%$ voor de totale categorie);

- van de werkenden blijkt een kleiner percentage te roken ( $59 \%$ versus $67 \%$; wanneer we het aantal sigaretten van de rokers bekijken, b11jkt er geen onderling verschil te zijn;

- een groter gedeelte van de werkenden gebrulkt alcoholische dranken ( $89 \%$ versus $79 \%$ ). De "drinkers" onder de werkenden gebruiken evenveel glazen alcoholhoudende dranken per week als de drinkende arbeidsongeschikten (respectievelijk 12,8 en 13,3 glazen);

- in het oordeel over de eigen leefwijze vinden we geen verschil.

Vergelijken we werkenden met werklozen, dan blijkt dat werkenden:

- overeenkomen in het percentage bij wie regelmatige lichaambeweging ontbreekt ( $47 \%$ resp. $45 \%)$;

- eenzelfde percentage rokers hebben ( $54 \%$ resp. $64 \%$ ), met een gelijk gemiddeld aantal sigaretten (17 resp. 16) per dag per roker;

- een gelijk percentage gebruikers van alcoholhoudende dranken hebben $(90 \%$ resp. $89 \%)$; werkenden drinken gemiddeld echter minder glazen. per week $(13,4$ versus 18,4$)$;

- een negatiever oordeel over de eigen leefwijze hebben (2,7 vergus $2,4)$

Vergelfjken we tot slot werkenden met vervroegd gepensioneerden dan zien we het volgende:

- het percentage werkenden dat niet aan Ilchaamsbeweging doet verschilt niet $(49 \%$ resp. $39 \%)$;

- In de categorle werkenden 1 s het percentage rokers hoger ( $59 \%$ versus $42 \%$ ). Het gemiddeld aantal sigaretten onder de rokers $1 \mathrm{~s}$ gelijk (17 resp. 18);

- zowel in het percentage gebruikers van alcoholhoudende dranken $(90 \%$ resp. 93\%) als in het gemiddeld aantal glazen per week onder de 
drinkers (12 resp. 11) komen werkenden en vervroegd gepensioneerden overeen;

- werkenden blijken een negatiever oordeel over de eigen gezondheld te hebben $(2,7$ versus 2,3$)$.

\subsection{Conclusies}

Dok hier zullen we omwille van de averzichtelijkheid de hypothesen herhalen, achtereenvolgens voor de vergell fkingen tussen niet werkenden onderling en tussen niet werkenden en werkenden.

Set 1. Niet werkenden onderling.

$$
\begin{aligned}
& \text { hypathese opmerkingen/ } \\
& \text { bevestigd bijzonderheden }
\end{aligned}
$$

1. 1 Arbeidsongeschikten vertanen

a. minder riskante gewoonten neen dan werklozen

b. meer riskante gewoonten dan vervroegd gepensioneerden
- gedeeltelijk meer (antbreken 1ichaamsbeweging; sigaretten roken)

- gedeeltelijk evenveel (overige variabelen) gedeelte- - gedeeltelijk meer contlijk ja breken lichaamsbeweging;percentage rokers)

- gedeeltelijk hetzelfde (arntal sigaretten en alcohol houdende dranken)

- gedeeltelijk minder (percentage gebrulkers alcoholhoudende dranken)

$$
\begin{aligned}
& \text { 1.2 Werklozen hebben meer neen overwegend geen ver- } \\
& \text { riskante gewoonten dan } \\
& \text { vervroegd gepensloneerden }
\end{aligned}
$$


Onze hypothesen worden overwegend verworpen; arbeidsongeschikten hebben eerder meer dan minder riskante gewoonten dan werklozen, zij hebben slechts gedeeltelijk meer riskante gewoonten dan vervroegd gepensioneerden. Werklozen blijken op hun beurt niet apvallend te verschillen van vervroegd gepensioneerden.

Voorts valt op dat arbeidsongeschikten een minder positief oordeel over de eigen leefwijze hebben dan werklozen en vervroegd gepensioneerden.

Set 2. Niet werkenden en werkenden.

$$
\begin{aligned}
& \text { hypothese opmerkingen/ } \\
& \text { bevestigd bifzonderheden }
\end{aligned}
$$

2. 1 a Arbeidsongeschikten hebben meer riskante gewoonten dan werkenden

$$
\begin{aligned}
\text { gedeelte- } & \text { - uitgezonderd aantal } \\
\text { lijk ja } & \text { sigaretten en aantal } \\
& \text { glazen alcoholhoudende } \\
& \text { dranken (evenveel) } \\
\text { - } & \text { uitgezonderd percen- } \\
& \text { tage gebrukers alco- } \\
& \text { holhoudende dranken } \\
& \text { (minder) }
\end{aligned}
$$

neen
glazen alcoholhoudende
dranken (meer)

\subsection{Vervroegd gepensioneerden groten- ultgezonderd percentage komen met. werkenden over- deels ja rokers (minder) een in riskante gewoonten}

Onze hypothesen worden gedeeltelijk bevestigd war het arbeldsongeschikten en verworpen waar het werklozen in vergelljking met de werkenden betreft. Dat werklozen overwegend niet verschillen van werkenden hadden we geenszins werwacht. Vervroegd gepensioneerden komen overwegend met werkenden overeen.

Hoewel we geen hypothesen geformuleerd hebben over het oordeel over de 
eigen leefwijze, achten wj het opvallend dat arbeidsongeschikten en werkenden bierin niet verschillen, terwijl werklozen en vervioegd gepensioneerden wel van werkenden verschillen door een positiever oordeel.

\subsection{Samenvatting}

- Uit de anderlinge vergelijking van de niet werkenden blijkt dat alle drte categorieën op éen aspect onderling verschillen: het percentage dat geen 1ichaamsbeweging heeft. Onder arbeldsongeschikten vinden we het kleinste en onder werklozen het grootste percentage mannen dat regelmatig 11 chaamsbeweging heeft.

Rokende arbeidsongeschikten roken voorts meer sigaretten dan werklozen, komen met vervroegd gepensioneerden hierin overeen en verschillen van vervroegd gepensioneerden door een lager percentage gebruikers van alcoholhoudende dranken. Vervroegd gepensioneerden en werklozen verschillen op deze laatste drie aspecten onderling niet. Vervroegd gepensioneerden onderscheiden zich van de andere twee categorieën alleen in het percentage rokers, dat bij hen het laagst is. Hierin verschillen arbeidsongeschikten en werklozen niet. Onder de drinkers blijken geen verschillen te bestaan tussen de drie categorieën in het aantal glazen alcoholhoudende dranken per week. Arbeldsongeschikten blijken het minst positieve oordeel over de elgen leefwlje te hebben, terwijl werklozen en veruroegd gepensioneerden niet verschillen.

- BIj de vergelijking van werkenden met arbeldsongeschikten blijkt dat werkenden zich drie keer wel (groter percentage met lichaamsbeweging, kleiner percentage rokers en groter percentage gebruikers alcoholhoudende dranken) en twee keer niet (aantal sigaretten en alcoholhoudende dranken) onderscheiden naar riskante gewoonten. In het oordeel over hun leefwijze verschilien zij niet.

Bij vergelijking van de werkenden met werklozen, blijkt dat werkenden op Een aspect minder riskante gewoonten hebben. Op de overige vier aspecten blijken er geen verschillen te zijn. Opvallend is het minder positieve oordeel over de eigen leefwijze van werkenden. In de vergelijking van werkenden met vervroegd gepensioneerden, 
blijken werkenden zich op éen van de vijf riskante gewoonten te onderschelden, namelijk een groter percentage rokers. Vergeleken met vervroegd gepensioneerden hebben werkenden een negatiever oordeel over de elgen leefwijze.

- Werkenden onderscheiden $z i c h$ vooral van arbeidsongeschikten (met gedeeltelijk minder en gedeeltelijk meer riskante gewoonten), in mindere mate van werklozen (met minder riskante gewoonten) en het minst (met meer riskante gewoonten) van vervroegd gepensioneerden. Opvallend is dat het oordeel over de eigen leefwijze van werkenden niet verschilt van dat van arbeldsongeschikten, terwijl werkenden in vergelijking met werklozen en vervroegd gepensioneerden een negatiever oordeel over de leefwijze hebben. 


\section{Participatie}

\subsection{Inle1ding}

Analoog aan de opzet van het voorgaande hoofdstuk behandelen we de resultaten van de analyse van particlpatie. In hoofdstuk 5 is deze term Inhoudelijk aan de orde gesteld. In het kort zullen we deze ulteenzetting hier nog even samenvatten.

We beginnen met een onschrijuing van de verschillende variabelen. warmee we participatie gemeten hebben.

- sociale contacten gemeten met de frequentie van contacten met vrienden/kennissen, famille en (ex-)collega's. De in de tabellen vermelde getallen verwijzen naar vijf scores: 1 = elke dag, 2 = een paar keer per week, 3 = Één keer per week, 4 = een paar keer per maand en $5=$ minder vaak.

Voor de omgang met (ex-)collega's hebben we ook het percentage mannen dat contacten onderhoudt per categorie berekend.

- participatie $1 n$ verenigingen/clubs, gemeten met het percentage dat lid hlervan $1 \mathrm{~s}$ én de tijdsbesteding (van de verenigingsleden) in uren per week.

- idemtificatie met het politieke bestel, gemeten met het al dan niet stemmen bij verkiezingen.

- Identificatie met kerkgenootschappen, gemeten met het al dan niet $11 d$ zijn van enig(e) kerkgenootschap, sekte of organisatie van levensbeschouwelijke aard.

ook hier zullen we steeds bekijken of er sprake is van verschillen tussen de nlet werkenden onderling $(14.2)$ én tussen de successieve1ijke categorieën niet werkenden en werkenden (14.3). Zoals eerder, laten we ons ook hier lelden door de resultaten na correctie.

In paragraaf 14.4 geven we de conclusies op basis van de hypothese weer. De sianenwating komt in 14.5 aan de orde. 
14.2 Een onderlinge vergelijking van niet werkenden naar particlpatie

In onderstaande tabel volgt een overzicht van de genoende vier onderwerpen, warvan de eerste twee (sociale contacten en particlpatie verenlgingen/clubs) naar een aantal aspecten geconcretiseerd $z i j n$.

Tabe1 14.1 Arbeidsongeschikte, werkloze en vervroegd gepensioneerde mannen onderling vergeleken nar particlpatie (1983).

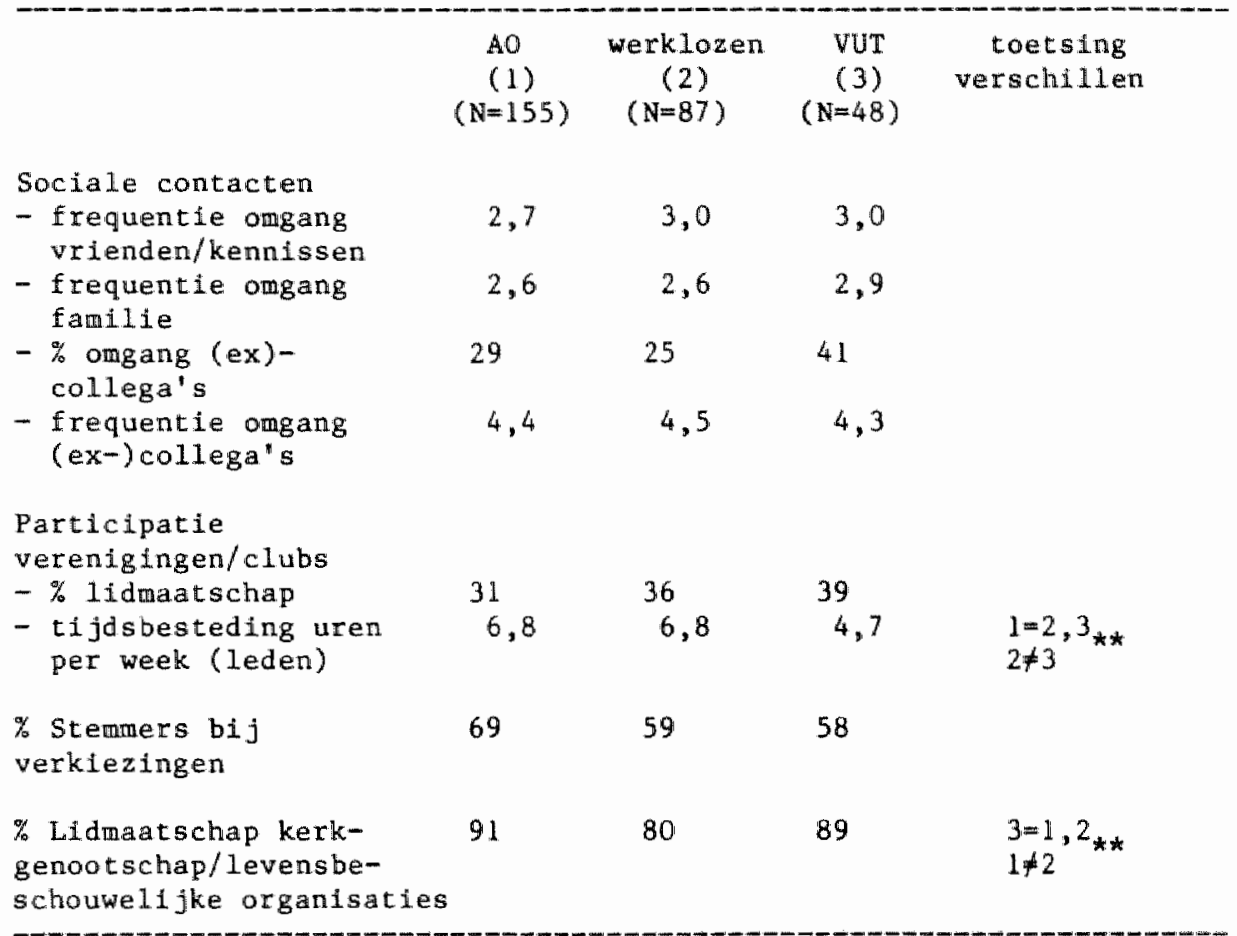

$* * .01<\mathrm{p} \leq .05$

$\star * \star=\quad \mathrm{p} \leq .01$

Tabel 14.1 laat zien dat:

- de drie categorieën eenzelfde gedrag vertonen met betrekking tot saclale contacten met vrienden/kennissen, familie en (ex-) collega"s;

- het percentage per categorie dat lid is van verenigingen/clubs onderling niet verschilt. Wel zien we dat vervroegd gepensioneerden minder uren per week aan clubs/verenigingen besteden. Zij blijken echter alleen van werklozen te verschillen $(4,7$ versus 6,8$)$. Arbeidsongeschikten en werklozen verschillen echter niet;

- het percentage stemmers bij verklezingen verschilt niet;

- arbeidsongeschikten relatief vaker lid zijn van een kerkgenootschap. 
$21 \mathrm{j}$ blifken in dit opzicht alleen te verschillen van werklozen ( $91 \%$ versus $80 \%$ ). Vervroegd gepensioneerden komen weer met arbeidsongeschikten en werklozen overeen.

De concluste luidt dat de niet werkenden ondering op zes van de acht aspecten van participatie overeenkomen. Verschilien vinden we alleen bij uren tijdsbesteding per week aan verenigingen en het percentage dat lid 18 van een kerkgenootschap.

\subsection{Een vergelijking naar particlpatie van werkenden en niet werken- den}

In deze paragraaf geven we een overzlcht van de statistische bewerkingen van de vergelijking tussen arbeidsongeschikten, werklozen en vervroegd gepensioneerden enerzijds en werkenden anderzijds (Tabel 13.2).

Tabel 14.2 Verschillen/overeenkomsten in participatie tussen werkende $(N=412)$ en niet werkende mamen (1983).

\begin{tabular}{|c|c|c|c|}
\hline & werker & eleken & \\
\hline & AO & WW & VUT \\
\hline $\begin{array}{l}\text { Sociale contacten } \\
\text { - frequentie omgang } \\
\text { vrienden/kennissen }\end{array}$ & $\min i_{* *}^{* * *}$ & 0 & 0 \\
\hline $\begin{array}{l}\text { - Erequentie ongang } \\
\text { familie }\end{array}$ & $\min ^{* * *}$ & 0 & 0 \\
\hline $\begin{array}{l}\text { - \% omgang (ex)- } \\
\text { collega's }\end{array}$ & $m e^{\star \star \star}$ & $\operatorname{me} e^{\star \hbar \hbar}$ & $\mathrm{me} e^{\star \star \star *}$ \\
\hline $\begin{array}{l}\text { - frequentie ongang } \\
(\mathrm{ex}-) \text { collega"s }\end{array}$ & 0 & 0 & 0 \\
\hline $\begin{array}{l}\text { Participatie } \\
\text { verenigingen/clubs }\end{array}$ & & & \\
\hline - \% Lidmaatschap & $\operatorname{me}_{* *}$ & me $e^{*}$ & 0 \\
\hline $\begin{array}{l}\text { - tijdsbesteding uren } \\
\text { per week (leden) }\end{array}$ & $\mathrm{mi}$ & 0 & 0 \\
\hline $\begin{array}{l}\text { W Stemmers bij } \\
\text { verklezingen }\end{array}$ & $\operatorname{men} e^{* *}$ & $\operatorname{me} e^{\star *}$ & 0 \\
\hline $\begin{array}{l}\text { H Ldmaatschap kerk- } \\
\text { genootschap/levensbe- } \\
\text { schouwelijke organisaties }\end{array}$ & 0 & 0 & 0 \\
\hline$* \quad: .05<p \leq .10$ & & & \\
\hline$* *: .01<\mathrm{p} \leq .05$ & & & \\
\hline $\begin{array}{l}* * *: P \leq .01^{-} \\
0=\text { geen verschil }\end{array}$ & 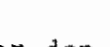 & & \\
\hline
\end{tabular}


Globaal bezien valt op dat werkenden het meest van abeldsongeschikten en het minst van vervroegd gepensioneerden verschillen.

Wanneer we per varlabele en per categorle niet werkenden de resultaten In ogenschouw nemen zien we bijwerkenden in vergelijking met arbeldsongeschikten:

- minder contacten met vrienden/kennissen $(3,2$ versus 2,7$)$;

- minder contacten met familie $(3,0$ versus 2,6$)$;

- een groter percentage dat ongang heeft met (ex-)collega"s (91\% versus 26\%); onder degenen die contacten hebben vinden we bij vergelijking van beide categorieën een even frequent contact met (ex)collega"s $(4,3)$;

- een hoger percentage dat $11 d$ is van een verenlging of club ( $49 \%$ versus 37\%); voor zover men $11 \mathrm{~d}$ is vinden we voor de werkenden een geringer aantal bestede uren per week aan vereniging of club $(4,6$ versus 6,7 uren);

- een hoger percentage dat bij verkiezingen zijn stem uitbrengt ( $94 \%$ versus $89 \%$ );

- geen verschil in het percentage dat lid is van een kerkgenootschap.

Werkenden blijken niet zelden te verschilien van werklozen. We zien:

- geen verschil in contactfrequentie met vrienden/kennissen $\langle 3,1$ versus 2,9$)$;

- eveneens geen verschil in contactfrequentie met familie $(2,9$ versus $2,7)$;

- een aanzienlifk hoger percentage dat contacten onderhoudt met (ex)collega's ( $91 \%$ versus $29 \%$ ); werkenden en werklozen die omgang hebben met (ex-)collega's, doen dat in gelijke mate $(4,3$ versus 4,3$)$.

- een hoger percentage dat $11 d$ is van verenigingen of clubs (50\% versus 38\%); in tijdsbesteding wan de leden vinden we geen verschil van betekenis $(4,5$ en 5,7 uren per week);

- een aanzlenlijk hoger percentage dat bif verklezingen zijn otem ultbrengt ( $94 \%$ versus $78 \%$ );

- geen verschil in het percentage dat 11d ls van een kerkgenootschap ( $57 \%$ versus $56 \%$ ).

Werkenden en vervroegd gepensioneerden komen vrljwel overeen in participatie. Onderlinge vergelijking leert ons dat er geen verschillen bestaan ten aanzien van: 
- contactfrequentie met vrienden/kennissen $(3,1$ versus 3,0$)$;

- contactrequentie met familie $(3,0$ versus 2,6$)$;

- contactrequentie met (ex-)collega"s voor zover men met hen omgat buiten het (vroegere) werk $(4,3$ versus 4,4$)$;

- het percentage dat lid is van verenigingen/clubs ( $50 \%$ versus $42 \%$ );

- t1 jdsbesteding aan verenigingen $(4,5$ versus 5,6$)$;

- het percentage stemmers b1j verkiezingen ( $95 \%$ versus 96\%);

- het percentage dat lid is van enig kerkgenootschap of organisatie van levensbeschouwelijke grondslag ( $58 \%$ versus $54 \%$ ).

Het enlge verschil betreft het percentage dat contacten met (ex-)collega's onderhoudt ( $89 \%$ versus $49 \%$ ).

14.4 Conclusies

Achtereenvolgens gewen we de conclusies op basis van de hypothesen weer vaor de vergelijkingen tussen nlet werkenden onderling en tussen niet werkenden en werkenden.

Set $\mathbb{1}$ Niet werkenden onderling

$$
\begin{aligned}
& \text { Hypothese Opmerkingen/ } \\
& \text { bevestigd bijzonderheden }
\end{aligned}
$$

1.1 Arbeidsongeschikten hebben neen vergeleken met werklozen een hogere participatiegraad

1.2 Arbeldsongeschikten hebben neen vergeleken met vervroegd gepenstomeerden een lagere participatiegraad

1.3 Merklozen hebben vergeleken neen met vervroegd gepensioneerden een lagere participatiegraad verschillen niet; uitgezonderd het percentage dat 1 id is van enig kerkgenootschap (arbeidsongeschikten bl1 jken vaker 1id)

verschillen niet verschillen niet; uitgezonderd tijdsbesteding verenigingen (werklozen hebben hogere participatiegraad) 
Onze hypothesen worden verworpen: de drie categorieèn nlet werkenden blijken onderling overwegend niet te verschilien in de mate warin $1 \mathrm{j}$ participeren.

Set 2 Niet werkenden en werkenden

Hypothese opmerkingen/
bevestigd bljzonderheden

gedeelte- geldt voor:

lijk ja - \% contacten met $(e x)$ collega's

- \% lidmatschap verenigingen en stemers bif verkiezingen

gedeelte- - meer contacten met $11 j k$ neen vrienden en familie, tijdsbesteding clubs

2.1b Werklozen hebben een lagere grotendeels participatiegraad dan neen werkenden

$$
\begin{aligned}
\text { gedeelte- } & -\% \text { contacten met (ex)- } \\
\text { lijk ja } & \text { collega's } \\
- & \% \text { lidmaatschap veren1- } \\
& \text { gingen } \\
- & \% \text { stemmers bij ver- } \\
& \text { klezingen }
\end{aligned}
$$

2.1c Vervroegd gepensioneerden ja uitgezonderd $\%$ omgang hebben eenzelfde particithet $(\mathrm{ex}-)$ collega's patiegraad als werkenden

\subsection{Samenvatting}

Op het merendeel der onderschelden aspecten komen de arbeidsongeschikte, werkloze en vervroegd gepensloneerde mannen onderilng overeen. Op geen enkel aspect verschilien de categorieèn alle drie van elkaar. 
Op twee van de acht aspecten vinden we verschillen: het aantal uren dat leden van verenigingen per week aan hun vereniging besteden (vervroegd gepensioneerden besteden minder uren dan werklozen), en het percentage dat aangerloten is bij een kerkgenootschap of organisatie op levensbeschouwelijke grondslag (onder arbeidsongeschikten is een groter gedeelte 11 d dan onder werklozen).

Werkenden blijken op twee van de acht aspecten met arbeidsongeschikten overeen te komen, op drie aspecten is de particlpatie minder en eveneens op drie meer.

Werkenden blijken op vijf van de acht aspecten met werklozen overeen te komen en op drie aspecten blifkt de participatie van werkenden groter. De verschilien tussen werkenden en werklozen wijzen in de richting van een hogere particfpatie van werkender.

Wanneer we de drie vergelijkingen nast elkaar leggen, springen de vervroegd gepensioneerden duidelijk in het oog: uitgezonderd het percentage omgang met (ex-)collega"s komen zij met werkenden geheel overeen.

Concluderend: werkenden komen het meest overeen met vervroegd gepensioneerden, en het minst met arbeidsongeschikten, terwijl werklozen een middenpositie innemen. 


\section{Conclusies en Discussie}

In tegenstelling tot onze verwachting blijken arbeidsongeschikten (lets) meer riskante gewoonten te hebben dan werklozen en vervroegd gepensioneerden. We achten het opvallend dat arbeidsongeschikten eerder méer dan minder riskante gewoonten hebben dan werkenden. Gelet op hum slechte gezondheid hadden we verwacht dat zij eerder ninder dan meer riskante gewoonten dan werklozen zouden hebben. Arbedisongeschukten blijken niet alleen een rislcogroep vanwege hun slechte gezondheld, mar ook wanwege hun ten dele méer riskante gewoonten (percentage rokers en percentage bij wie regelmatig lichamsbeweging ontbreekt). Niettemin winden we onder arbeidsongeschikten een lager percentage gebruikers van alcoholhoudende dranken dan onder werkenden, hoewel de "drinkers" onder hen evenveel glazen tot zich nemen als de "drinkers" onder de werkenden. De bevinding dat arbeidsangeschikten méer riskante gewoonten hebben dan vervroegd gepensioneerden komt met onze verwachting overeen, hoewel wij een groter verschil veronderstelden.

Vergeleken met werkenden verschillen werklozen en vervraegd gepensioneerden nauwel1jks; onder werklozen hadden we mér riskante gewoonten dan onder werkenden verwacht.

Dat arbeldsongeschikten hun leefwijze als minder gezond beoordelen dan de andere twee categorleän niet werkenden, behoeft ons nu niet meer te verbazen, gezien hun riskante gewoonten.

De overeenkomst van werkenden en arbeidsongeschikten in de beoordeling van de eigen leefwijze 1 ijkt derhalve niet herleld te kunnen worden tot eenzelfde profiel inzake riskante gewoonter. Het $11 \mathrm{gt}$ voor de hand te veronderstellen dat het verschll in wel en geen betaflde arbeld verrichten hieraan tenminste mede debet is. In dat geval zouden werkenden en werklozen ook moeten verschillen; dit blijkt echter nlet het 
geval. We gaan we er daarom vanuit dat onder niet werkenden het oordeel over de elgen leefwijze met gezondheld en riskante gewonten samenhangt, terwijl onder werkenden het oordeel over de eigen leefwijze met het verrichten van betalde arbeid samenhangt.

Tot zower de riskante gewoonten als eén aspect van de leefwijze.

Wat betreft particlpatie zijn de onderlinge verschillen minder groot dan wat betreft riskante gewoonten: de drie categorieën niet werkenden komen overwegend onderling overeen. Het entge opvallend onderscheid is dat onder werklozen een kleiner percentage lid is van kerkgenootschappen dan onder arbeldsongeschikten. Wanneer we niet werkenden met werkenden vergelljken valt op dat vervroegd gepensioneerden vrijwel geheel, werklozen gedeeltelfjk en arbeidsongeschikten in beperkte mate met werkenden overeenkomen. Binmen alle drie categorieën onderhoudt een kleiner percentage contacten met (ex-)collega's dan onder werkenden. Deze bevinding zal nlemand verbazen. Opvallend is dat onder arbeidsongeschikten en werklozen vergeleken met werkenden een kleiner percentage 11d is van verentgingen/clubs en een kleiner percentage bij. verklezingen hun stem uitbrengt. Even opvallend is dat arbeldsongeschikten vergeleken met werkenden niet minder frequent meer juist frequenter contacten onderhouden met vrienden/kennissen en familie én meer uren besteden aan verenigingen en clubs.

Gelet op het onderscheiden profiel van arbeidsongeschikten en werklozen in relatie tot werkenden mogen we aannemen dat de oorzaak van het niet werken (ongezondheid versus ontbreken van betalide arbeid) onderscheiden consequenties heeft voor participatie. Gedwongen niet werken, dat voor belde categoriean geldt, kan kennelijk wel tot politieke apathie (niet stemmen) lefden en het minder vaak lid $z i j n$ van verenigingen.

Wanneer we letten op contacten met mensen uit de directe omgeving (vrlenden/kennissen, famflie) verschillen werklozen niet van werkenden, terwijl arbeidsongeschikten zelfs frequenter contact hebben dan werkenden.

Voorzover er sprake is van maatschappelifke scheidslijnen in particlpatie bestaat er een gedeeltelijke scheidslijn tussen enerzijds ar- 
beldsongeschikten en werklozen en anderzijds werkenden en vervioegd gepensioneerden.

Wat betreft riskante gewoonten loopt de voornaamste gedeeltelijke scheidslijn tussen enerzijds arbeidsongeschikten en anderzijds werklozen, vervroegd gepensioneerden en werkenden. 

Deel IV: De Duur van het Niet Werken

16. Inleiding Deel IV

17. Een Tranversale Analyse

18. Een Longitudinale Analyse

19. Conclusies en Discussie 



\section{Inleiding Deel IV}

In dit deel zullen we uitsluitsel geven over de samenhang tussen de duur van het niet werken en bovengenoemde onderwerpen. We volgen hiertoe twee wegen. De eerste betreft een transversale analyse door langdurig en kortdurig niet werkenden met elkaar te vergelljken (hoofdstuk 17). Zo we verschillen vinden, is nog geensins duidelijk of deze verschillen verklaard kunnen worden vanuit een selectie-effect dan wel een causal effect. Wanneer bijvoorbeeld uit de transversale analyse blijkt dat langdurig niet werkenden een slechtere gezondheld hebben dan kortdurig niet werkenden kan dit het gevolg z1jn wan het felt dat degenen met een goede gezondheid wel en met een minder goede gezondheid geén werk hebben kunnen vinden (selectle-effect). Het is eveneens mogelijk dat het verschil in gezondheid het gevolg is van een negatleve Invloed van de duur van het niet werken op gezondheid (causaal effect). Zo dit laatste het geval is moet dit uit een longltudinale analyse naar voren komen. Het is ufteraard eveneens mogelijk dat er zowel sprake is van een selectie-effect als van een causaal effect. De resultaten van deze amalyse worden in hoofdstuk 18 gerapporteerd.

De analyses zijn op dusdanige wijze uitgevoerd dat in geval van transversale analyses de invloed van achtergrondkenmerken uttgeschakeld 1 s met behulp van ANOVA. Bij de longitudinale analyses hebben we de invloed van de achtergrondkenmerken ultgeschakeld door preciate-matching van niet werkenden met werkenden. Meer informatie hierover wordt in de inleidingen van de afzonderlijke hoofdstukken gegeven, alsmede in hoofdstuk 5 .

In de afslufting van de afzonderlijke hoofdstukken geven we de conclusies en de samenvatting weer.

In hoofdstuk 19 zetten we de conclusles van de transverbale en longl- 
tudinale analyses nast elkaar. Ondat we niet alle hypothesen transversaal én longitudinaal hebben kunnen toetsen, zoals die over de beheersingsoriëntatie, kunnen we soms geen uitsluitsel geven over de richting van de relaties.

Tot slot wijzen we erop dat vervroegd gepensioneerden wel transversaal mar niet longitudinad geanalyseerd $z 1 \mathrm{jn}$. Het aantal gematchte vervroegd gepensioneerden dat na matching overbleef ( 8 ) bleek dusdanig kleln dat we hiervan afgezien hebben. 


\section{Een Tranversale Analyse}

\section{Inleiding}

De vraag die hier central staat is of langdurig en kortdurig niet werkenden onderling verschillen op de eerder besproken variabelen. We houden de volgorde aan zoals deze in de voorgaande hoofdstukken aan bod gekomen is: gezondheld, gezondheidsopvattingen, riskante gewoonten en participatie. Per onderwerp komen de arbeidsongeschikten, werklozen en vervroegd gepensioneerden apart an de orde.

Per tabel zullen we darom steeds voor elke categorie afzonderlijk de langdurig met de kortdurig niet werkenden vergelijken. De verdeling van de antalien respondenten over de rubrieken lang- en kortdurig niet werkend is overeenkomstig die welke in hoofdstuk 5 aangegeven werd.

On uit te sluiten dat eventuele verschillen (mede) samenhangen met leeftijd, burgerlifke staat en sociaal-economische klasse, zullen we steeds voor deze variabelen corrigeren.

In de tabellen geven. we per variabele aan of er sprake is van overeenkomst of verschil; het verschil zullen we uitdrukken in de termen "minder" of "meer". 


\section{2 Gezondhe1d en gezondheidsopvatt1ngem}

\section{2 .1 Gezondheid}

In tabel 17. 1 komt naar voren dat er sprake is van twee verschillen; belde betreffen het percentage chronische aandoeningen.

Zowel langdurig arbeidsongeschikten als werklozen rapporteren een hoger percentage chronische aandoeningen dan kortdurig niet werkenden; respect lewelifk $76 \%$ versus $60 \%$ en $31 \%$ versus $11 \%$.

De lang- en kortdurig vervroegd gepensioneerden verschillen onderling niet.

Tabel 17.1 Verschillen en overeenkomsten in gezondheid tussen lang- en kortdurig niet werkende mannen (1983).

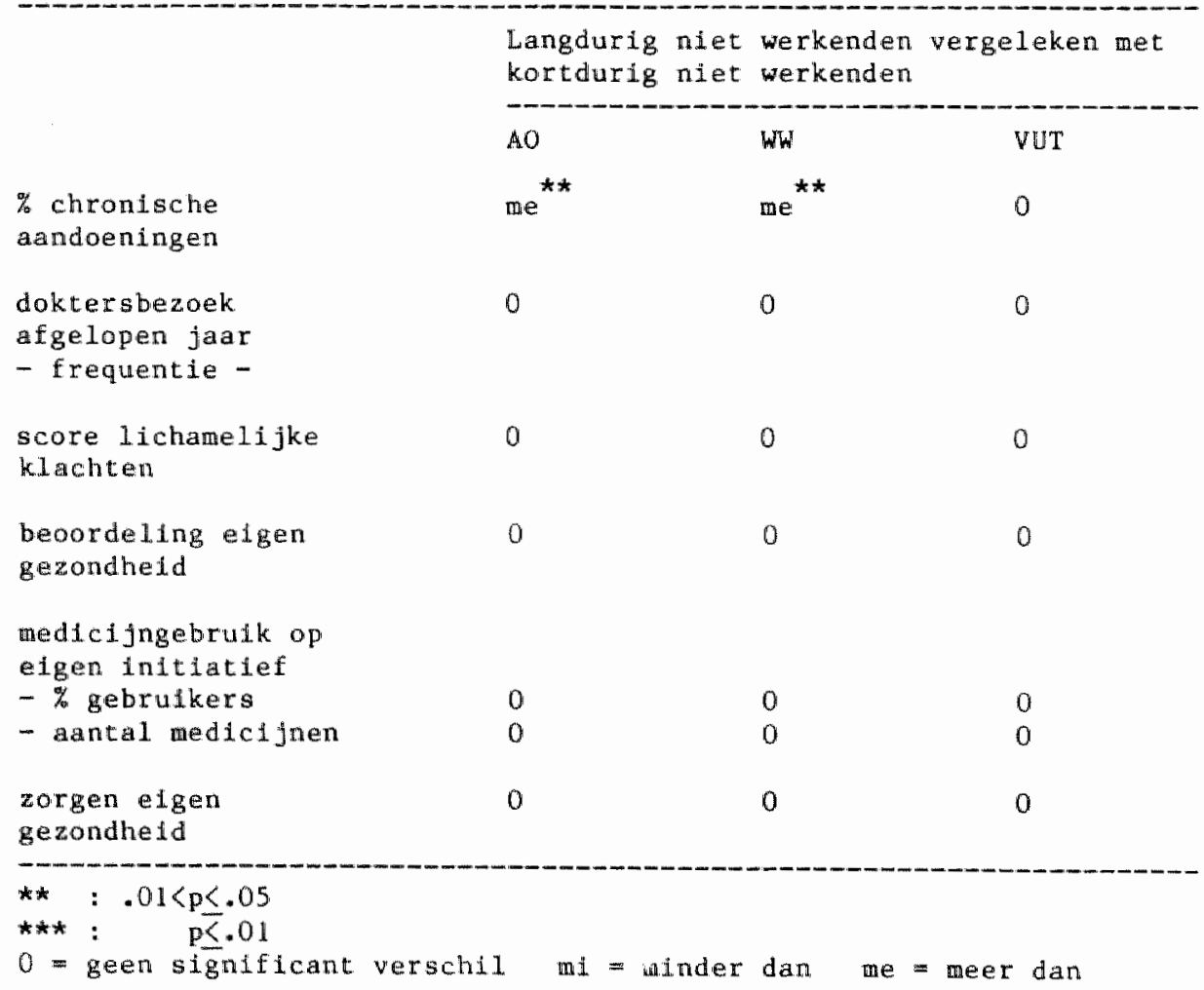




\subsubsection{Gezondheidsopvattingen}

Uit tabel 17.2 blijkt dat er nawwelijks sprake van verschillen is in gezondheidsopvattingen tussen lang- en kortdurig niet werkenden. Het enige verschil betreft de arbeidsongeschikten: langdurig arbeidsongeschikten zijn meer toeval- of kansgeoriënteerd dan kortdurig arbeidsongeschikten $(20,7$ versus 18,5$)$.

\section{Tabel 17.2 Verschillen en overeenkomsten in gezondheidsopvattingen tussen Iang- en kortdur1g niet werkende mannen (1983).}

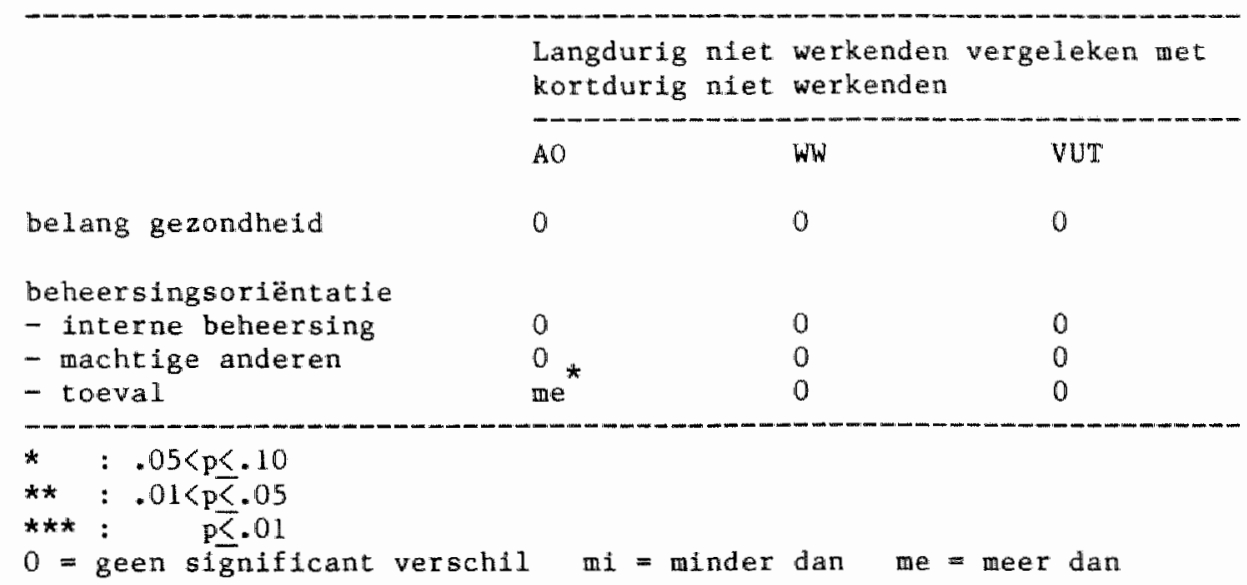




\subsection{Righante gewoonten en oordeel eigen leefwiljze}

In de volgende tabel vergelijken we wederom, per categorie, de langen kortdurig niet werkenden.

Tabel 17.3 Verschillen en overeenkomsten in riskante gewoonten en oordeel eigen leefwijze tussen lang- en kortdurig niet werkende mannen (1983).

\begin{tabular}{|c|c|c|c|}
\hline & $\begin{array}{l}\text { Langdurig niet } \\
\text { kortdurig niet }\end{array}$ & $\begin{array}{l}\text { werke } \\
\text { werke }\end{array}$ & leken 畔e \\
\hline & $\mathrm{AO}$ & $W W$ & VUT \\
\hline $\begin{array}{l}\text { \% ontbreken } \\
\text { lichaamsbeweging }\end{array}$ & 0 & 0 & $m e^{*}$ \\
\hline $\begin{array}{l}\text { roken } \\
\text { - \% rokers } \\
\text { - antal } 1 \text { garetten } \\
\text { per dag (rokers) }\end{array}$ & $\operatorname{me}^{* *}$ & $\operatorname{me}^{\star *}$ & $\begin{array}{l}0 \\
0\end{array}$ \\
\hline $\begin{array}{l}\text { alcoholgebruik } \\
\text { - \% gebruikers } \\
\text { - aantal glazen per } \\
\text { week (drinkers) }\end{array}$ & $\begin{array}{l}a \\
a\end{array}$ & 0 & $\begin{array}{l}0 \\
0\end{array}$ \\
\hline $\begin{array}{l}\text { negatief oordeel over } \\
\text { eigen leefwjjze }\end{array}$ & 0 & $\mathrm{me} \mathrm{e}^{* *}$ & 0 \\
\hline 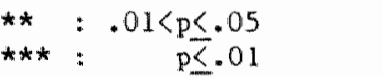 & & & \\
\hline
\end{tabular}

Terzake van riskante gewoonten en het oordeel over de eigen leefwijze komen langdurig niet werkenden overwegend overeen met kortdurig niet werkenden. De wer verschllen die we vinden zijn verdeeld over de drie categorieën:

- onder langdurig vervroegd gepensioneerden vinden we een hoger percentage manen bif wie regelmatige lichamsbeweging ontbreekt ( $65 \%$ versus 38\%);

- onder langdurig werklozen en arbeidsongeschikten biljkt een hoger percentage te roken (respectievelijk $71 \%$ versus $57 \%$ en $86 \%$ versus $62 \%$ );

- langdurig werklozen blifken een negatiever oordeel over de eigen leefwijze te hebben. 


\subsection{Particlpatie}

Evenals in de vorige tabellen geven we ook nu de verschillen tussen de lang- en kortdurig niet werkenden. Zo er verschillen zijn vermelden we de richting van de verschillen.

We vinden alleen significante verschillen onder arbeidsongeschikten en werklozen:

- onder langdurig arbeidsongeschikten gaat een kleiner percentage nog met (ex-) collega's om (21\% versus $42 \%$ );

- langdurig werklozen gaan minder frequent met familieleden om $(2,6$ versus 2,8 );

- onder langdurig werklozen brengt een kleiner gedeelte zijn stem uit bij verkiezingen ( $58 \%$ versus $82 \%$ ).

Tabel 17.4 Verschillen en overeenkomsten in participatie tussen langen kortdurig niet werkende mannen (1983).

Langdurig niet werkenden vergeleken met kortdurig niet werkenden

AO WW WUT

Sociale contacten

- frequentie omgang vrlenden/kennissen

- frequentie omgang. familie

- \% omgang (ex)collega"s

- frequentie omgang $(\mathrm{ex}-)$ collega's

$\begin{array}{lll}0 & 0 & 0 \\ 0 & \mathrm{mi}^{* *} & 0 \\ 0 & 0 & 0\end{array}$

Participatie verenigingen/clubs

- \% I1dmatschap

- tijdsbesteding uren

$\begin{array}{lll}0 & 0 & 0\end{array}$ per week (leden)

stemers b

0

0

0

verkiezingen

\% Lidmaatschap kerkgenootschap/levensbe- 


\subsection{Conclusies.}

Achtereenvolgens geven we de conclusies op basis van de hypothesen weer voor de vergelijkingen tussen de lang- en kortdurig niet werkendert.

\section{Gerapporteerde}

gezondhe1d
Hypothese Opmerkingen/

bevestigd bijzonderheden

1.1 Langdurtg arbeldsongeschikten

hebber vergeleken met kort-

durig arbeldsongeschikten:

a een slechtere subjectieve neen

gezondhetd

b een slechtere objectieve gedeelte- - * chronische andoegezondheid. $1 \mathrm{ijk}$ ningen: ja

- doktersbezoek: neen

1.2 Langdurig werklozen hebben vergeleken met kortdurig werklozen:

a een slechtere subjectieve neen gezondheid

b een slechtere objectieve gedeelte- - \% chronische aandoegezondheid lijk ningen: ja

- doktersbezoek: neen

1.3 Langdurig vervroegd gepenstoneerden hebben vergeleken met kortdurig vervroegd gepensioneerden:

a eenzelfde subjectieve ja gezondheid

b eenzelfde objectieve ja gezondheid 
Onze hypothesen inzake arbeldsongeschikten en werklozen blijken gedeeltelijk verworpen te worden wat betreft de objectleve gezondheid; ze worden geheel verworpen wat betreft de subjectieve gezondheld. Die met betrekking tot vervroegd gepensioneerden worden bevestigd.

Het percentage chronische aandoeningen is de enige variabele warop langdurig arbeldsongeschikten en werklozen verschillen van de respectievelijke kortdurig nfet werkenden: langdurig (gedwongen) niet werkenden omvatten een hoger percentage mensen met chronische aandoeningen dan kortdurig (gedwongen) niet werkenden.

2 Gezondheidsopvattingen

2.1 Belang gezondheid

a Langdurig arbeidsongeschikten neen achten gezondheid belangrijker dan kortdurig arbeidsongeschikten

b Langdurig werklozen achten gezondheid belangrijker dan kortdurig werklozen

c Langdurig vervroegd gepensioneerden komen overeen met kortdurig vervroegd gepensioneerden

2.2 Interne beheersingsoriëntatie

a Langdurig arbeidsongeschikten hebben een lagere beheersingsorlëntatie dan kortdurig arbeldsongeschikten

b Langdurig werklozen hebben een lagere beheersingsoriëntatie dan kortdurig arbeidsongeschikten

c Langdurig vervroegd gepensioneerden komen overeen met kortdurig vervroegd gepensioneerden
Hypothese Opmerkingen/

bevestigd bijzonderheden

neen verschillen niet

ja

neen verschillen niet

neen verschillen niet verschilien niet verschillen niet 
2.3 Externe beheersingorientatie

a Langdurta arbeldgongeschiken hebben een hogere externe

orientatie dan korturig

arbeldsongeschikten

b Langdurig werklozen hebben

neen

verschillen niet

een hogere externe orfëntatie

dan kortdurfg werklozen

c Langdurig vervroegd gepen-

sioneerden komen met

kortdurig, verviaegd gepen-

sloneerden overeen

Onze hypothesen 1mzake arbeidsongeschikten en werklozen worden geheel verworpen. Die inzake vervroegd gepensioneexden worden bevestigd. Het enige verschil dat we exploratief gevonden hebben betreft de toevalsof kansorlëntatie: langdurig arbeldsongeschikten zijn mér toeval- of kansgeoriënteerd dan kortdurig arbeidsongeschikten.

3. Riskante gewoonten

$$
\begin{aligned}
& \text { Hypothese Opmerkingen/ } \\
& \text { bevestigd bijzonderheden }
\end{aligned}
$$

3.1 Langdurig arbeidsongeschik- neen

uttgezonderd roken: meer ten hebben méer riskante

gewoonten dan kortdurig

arbeidsongeschikten

3.2 Langdurig werklozen

neen

uitgezonderd roken: meer

hebben mếr riskante

gewoonten dan kortdurig

werklozen

3.3 Langdurig vervroegd gepen-

groten- uitgezonderd lichams-

stoneerden komen overeen.

deels ja beweging: minder

met kortdurig vervroegd

gepensioneerden

Dok hier blijkt dat onze hypothesen over arbeidsongeschikten en werklozen verworpen worden. Dit geldt - wederom - niet voor vervroegd 
gepensioneerden. Onder alle drie categorleën vinden we op een ondergeschikt aantal riskante gedragingen onderlinge verschillen: onder langdurig vervroegd gepensioneerden zien we een hoger percentage mannen bij wie regelmatig lichaamsbeweging ontbreekt; onder langdurig werklozen en arbeidsongeschikten blijkt een hoger percentage rokers dan onder kortdurig niet werkenden.

Exploratie van de variabele "oordeel over de eigen leefwjze" levert het volgende resultaat op: alleen langdurig werklozen verschillen van kortaurig werklozen, terwijl we onder de andere twee categorieern geen verschillen vinden. Langdurig werklozen achten hun leefwijze minder gezond dan kortdurig werklozen.
4. Participatie
Hypothese Opmerkingen/
bevestigd bijzonderheden

4.1 Langdurig arbeidsongeschikten

hebben wergeleken met kortdurig arbeidsongeschikten

- lagere participatiegraad

neen

uitgezonderd: kleiner \% omgang met $(e x-)$ collega's

4.2 Langdurig werklozen hebben vergeleken met kortdurig werklozen

- lagere participatiegraad

neen $\quad$ uitgezonderd:
- kleiner $\%$ stemers bij
$\quad$ verkilezingen
- toinder contacten
famille

4.3 Langdurig en kortdurig ja vervroegd gepenstioneerden verschlllen niet

Wederom worden de hypothesen inzake arbeidsongeschikten en werklozen verworpen en die van vervroegd gepensioneerden bevestigd. Wat betreft particlpatie blifken de lang- en kortdurig niet werkenden nlet vaak te verschillen. De gevonden verschillen betreffen arbeldsongeschikten en werklozen: langdurig werklozen hebben minder frequent ongang met 
Familie en omvaten een kleiner aantal stemers bij verkiezingen dan kortdurlg werklozen. Onder langdurig arbeldsongeschikten gat een kleiner percentage met (ex-) collega's om dan onder kortdurig arbeidsongeschikten.

Concluderend mogen we stellen dat:

1 het antal gevonden verschillen gering is in relatie tot het aantal verwachte verschilien;

2 megen van de tien verschilien betrekking hebben op arbeldsongeschikten en werklozen.

Deze verschillen zijn verspreid over de vier thema's gezondheid, gezondheldsopvattingen, riskante gewoonten en partipatie.

onder vervroegd gepensioneerden blijkt slechts éen verschil: van degenen die lange tijd zonder werk zijn, heeft een kleiner percentage 1Lchaamsbeweging dan van degenen die karte tijd zonder werk zijn.

\subsection{Samenvatting}

De transversale vergelijking tussen lang- en kortdurig niet werkenden levert per categorle weinig onderlinge verschillen op.

Onder langdurig arbeldsongeschikten vinden we, vergeleken met kortdurig arbeidsongeschikten:

- een groter percentage mannen met chronische aandoeningea;

- de opvatting dat gezondheld sterker door het toeval bepaald wordt;

- een groter percentage rokers;

- een kleiner percentage dat met (ex-)collega's contacten onderhoudt. Onder langdurig werklozen vinden we, vergeleken met kortdurig werklozen:

- een grater percentage mannen met chronische aandoeningen;

- een groter percentage rokers;

- een negatiever oordeel over de eigen gezondheld;

- een minder frequente omgang met famille;

- een kleiner percentage dat bij verkiezingen zijn stem uitbrengt. onder langdurig vervroegd gepensioneerden vinden we, vergeleken met kortdurig vervroegd gepensioneerden, éen verschil: een hoger aantal mannen bij wie regelmatige lichaambeweging ontbreekt. 


\section{Een Longitudinale Analyse}

\subsection{Inleiding}

In dit hoofdstuk zullen we uitsluitsel geven over de vraag of bij de afzonderlijke categorieën de duur van het niet werken $(' 81-' 83)$ invloed heeft op variabelen van de afzonderlijke thema's of onderwerpen. Tenelinde te kunnen vaststellen of eventuele veranderingen voortvloeien uit de tijdsduur dat betaald werk ontbreekt, hebben we de niet werkenden gematcht met werkenden. Beide categorieën zijn in de analyse opgenomen. Om tot zo genuanceerd mogelijke ultspraken te komen hebben we werkenden en niet werkenden met elkaar vergeleken in 1981 ên in 1983; daarnaast hebben we voor onderzoekgroep en contrastgroep afzonderlijk vastgesteld of er verschillen zijn over de periode 1981-1983. Ook de transwersale analyses tussen nlet werkenden en werkenden zijn van belang om tot verantwoorde "longltudinale" uitspraken te komen. De matching procedure was als volgt: bij elke niet werkende is een werkende partner gezocht die overeenkomt in burgerlijke staat (gehuwd/ samenwonend versus alleenstaand), leeftijdsklasse (10 jaarklassen), sociaal-economische status (drie klassen: de twee hoogste, de midden en de twee laagste), landsdeel (vier delen: noord, oost, west en zuid) en urbanisatiegraad (drie klassen: stad, geurbanlseerd platteland en platteland).

Langs deze weg hebben we 55 (van de 92) arbeidsongeschikten, 17 (van de 21) werklozen en 8 (van de 27) vervroegd gepenstoneerden kunnen paren. Het tekort onder vervroegd gepensloneerden en arbeldsongeschikten vloelt voort ult de ondervertegenwoordiging van werkende ouderen van 60 jaar en ouder onder de 264 werkenden die in 1981 en 1983 geIntervlewd zijn. Dit behoeft ons nlet te verbazen, gelet op het in hoofdstuk 2 vermelde relatlef geringe aantal werkende mannen van 60 jaar en ouder. 
Vanwege de relatief klelne aantalien binnen de gematchte groepen dienen we enige voorzichtigheid in acht te nemen bij de conclusies. We tekenen hierbif echter aan dat scores op varlabelen van de grotere aantallen nlet gematchte arbeldsongeschikten $(N=92)$, werklozen $(N=21)$ en vervroegd gepensioneerden $(N=27)$ in 1981 en 1983 vrijwel geheel overeenkomen met de gematchte kleinere aantallen. Desondanks hebben we besloten de vervroegd gepensioneerden buiten deze rapportage te houden; het aantal van 8 achten we te klein om aan de uitkomsten enige betekenis te kunnen geven. Om een tweetal redenen zijn per onderwerp (gezondhedd, enzovoorts) een beperkt aantal variabelen in de verge$11 \mathrm{jking}$ betrokken:

1 de variabelen die in 1983 gemeten $z i j n$, waren slechts voor een gedeelte in 1981 in het onderzoek opgenomen;

2 sommige varlabelen in belde deelonderzoeken zijn niet op overeenkomstige wijze gemeten.

Voor de overzichtelijkheid bespreken we telkens én categarie niet werkenden. Dientengevolge komen, in afwijking van de hoofdstukken 8 , 12 en 13 in elke paragraaf alle onderwerpen aan de orde: gezondheid, gezondheldsopvattingen, riskante gewoonten/oordeel van de eigen leefwije en participatie. Alle variabelen zijn per onderwerp in én tabel ondergebracht, zodat met eên oogopslag vastgesteld kan worden of er sprake is van:

- verschillen per jaar tussen niet werkenden en de met hen gematchte werkenden;

- verandertrigen onder niet werkenden en werkenden over de periode 1981-1983.

We wijzen erop dat we bij de in dit hoofdstuk vermelde resultaten voorbijgaan aan de ultval onder de drle categorleën vanwege ziekte en overlijden en vanwege werkhervatting. In hoofdstuk 19 komen we hierop terug. Selectieve uitval kan immers anlelding vormen de resultaten van dit hoofdstuk te herzien.

Bij elke vergelijklng hebben we per varlabele de scores vermeld, de rekenkundige gemiddelden, en de p-waarden. Statistische tweezijdige toetsing tussen de partner-categorieën berust op de Mann-Whitney U-Wllcoxon Rank Sum W Test; eenzijdige toetsing per deelcategorie over $1981 / 1983$ vindt plaats aan de hand van de Wilcoxon Matched Pairs Signed Rank Test. 


\subsection{Arbeldsongeschikten en werkenden}

Achtereenvolgens bespreken we gezondheid, gezondheldsopvatingen, riskante gewonten/oordeel over de eigen leefwijze en particlpatie.

\subsubsection{Gezondheid}

In tabel 18.1 komen de bevindingen inzake gezondheid aan de orde.

Tabel 18.1 Vergelljking genatchte paren arbeidsongeschikten en werkenden over 1981,1983 en ' $81 /$ '83 naar gezondheld $(N=55$ paren).

$\begin{array}{llll}81 \quad \mathrm{p} & 83 & \mathrm{P} & \mathrm{P} / \mathrm{8}\end{array}$

\% chronische aandoeningen arbeidsongeschikten

werkenden

76

69

.00

20

.00

frequentie doktersbezoek

arbeidsongeschikten

5.8

.00

werkenden

1.9

.00

Lichameli jke klachten arbeidsongeschikten

$\begin{array}{lllll}8.5 & & 7.4 & .02 \\ 3.6 & .00 & & .00 & -\end{array}$

beoordeling gezondheld ${ }^{*}$ arbeldsongeschikten.

$\begin{array}{ll}3.2 & .00\end{array}$

3.3

werkenden

4.0

4.1

.00

\% medicljn gebrulk op elgen initiatief

arbeldsongeschikten

51

.06

werkenden

33

53

43

$\begin{aligned} *: & =\text { zeer slecht } \\ 3 & =\text { mat } 1 \mathrm{~g} \\ 5 & =\text { zeer goed }\end{aligned}$


Zowel voor 1981 als voor 1983 geldt, dat arbeldsongeschikten op bijna alle variabelen afuljken van werkenden. Arbeiasongeschikten blijken in relatile tot werkenden:

- een hoger percentage chronische aandoeningen te hebben;

- vaker de dokter te bezoeken;

- meer lichamelijke klachten te uiten;

- een slechtere beoordeling van de elgen gezondheld te rapporteren. Wat het percentage medicijnengebrukers betreft, zien we dat arbeidsongeschikten in 1981 een tendens vertonen hoger te scoren dan werkenden, terwj1 wij in 1983 nlet meer van hen verschillen. Dit vloelt voort ult een niet significante toename onder werkenden over de periode $81-83$.

Voorts valt op dat over de periode 1981 tot 1983 nauwelijks veranderingen in gezondheid geconstateerd kunnen worden bij arbeidsongeschikten en werkenden. De enige verandering betreft een vermindering in 11chamelijke klachten bij arbeidsongeschikten tussen 1981 en 1983 van 8.5 nar 7.4.; onder werkenden vinden we een niet signiflcante afname van lichamelijke klachten.

Concluderend mogen we stellen dat onder arbeidsongeschikten het niet werken gepaard gat met een vermindering van het aantal lichamelijke klachten.

18.2.2 Gezondheidsopvattingen

De resultaten over gezondheidsopvattingen worden in tabel 18.2 weergegeven.

Tabe1 18.2 Vergelijking gematchte paren aroeidsongeschikten en werkenden naar gezondheldsopvattingen over 1981,1983 en ' $81 /{ }^{\prime} 83$ ( $N=55$ paren).

\begin{tabular}{|c|c|c|c|c|c|}
\hline & 81 & $p$ & 83 & $\mathrm{p}$ & $\begin{array}{c}81 / 83 \\
\mathrm{p}\end{array}$ \\
\hline $\begin{array}{l}\text { Belang gezondheid* } \\
\text { arbeidsongeschikten } \\
\text { werkenden }\end{array}$ & $\begin{array}{l}12.8 \\
12.1\end{array}$ & .06 & $\begin{array}{l}12.7 \\
12.7\end{array}$ & - & $\begin{array}{l}- \\
-\end{array}$ \\
\hline
\end{tabular}


In tabel 18.3 vinden we bif twee van de vier variabelen tendensen tot verschllen. Arbeidsongeschlkten 11 jken vergeleked met werkenden:

- In 1981 een klelner percentage gebruikers van alkohollsche dranken te onvaten; in 1983 is er geen onderling verschil meer ten gevolge van een, niet signiflcante, toename van het percentage gebruikers van alkoholhoudende dranken onder arbeidsongeschikten;

- In 1981 een even groot en in 1983 een groter percentage rokers te omvatten. Dit verschil blijkt herleid te kunnen worden tot een sterkere daling van het percentage rokers onder de werkenden ten opzlchte van de arbeidsongeschikten over de periode 1981 tot 1983.

De duur van het niet werken leldt er niet toe dat arbeldsongeschikten vergeleken met werkenden minder gaan roken.

\subsubsection{Participatie}

Bij het vierde onderwerp, particlpatie, bespreken we het percentage stemmers bij verkiezlngen en het percentage dat rapporteert lid te zijn van enig kerkgenootschap of organisatie van levensbeschouwelijke aard. In tabe1 18.4 worden de resultaten weergegeven.

Tabel 18.4 Vergelijking gematchte paren arbeldsongeschikten en werkenden naar participatie over 1981, 1983 en ' $81 /^{\prime} 83 \quad$ ( N $=55$ paren).

$81 \quad \mathrm{p}$

\% stemers bij verkiezingen arbeidsongeschikten werkenden

\% lidmaatschap kerkgenootsch.
95

94

65

74
a rbeldsongeschikten werkenden

$-$

83

p

$81 / 83$

$\mathrm{p}$
93

98

60

65

In de voorgaande tabel valt éen verschil te constateren, namelijk bij de werkenden tussen 1981 en 1983: over een periode van twee jaar zien we een afname van het percentage werkenden dat rapporteert lid te $z i j n$ van enig kerkgenootschap. 
Concluderend kunnen we stellen dat onder arbeidsongeschikten vergeleken met werkenden de duur van het niet werken niet gepaard gaat met een daling van het percentage dat zichzelf als lid beschouwt van enig kerkgenootschap.

\subsection{Werklozen en werkenden}

Conform de opzet van paragraaf 18.2 bespreken we de bevindingen inzake werklozen en werkenden.

18.3.1 Gezondheid

De resultaten inzake gezondheid worden weergegeven 1 n tabel 18.5 .

Tabel 18.5 Vergelfjking gematchte paren werklozen en werkenden over 1981,1983 en $181 / 83$ naar gezondheid ( $N=55$ paren).

\begin{tabular}{|c|c|c|c|c|c|}
\hline & 81 & $\mathrm{p}$ & 83 & $\mathrm{p}$ & $\begin{array}{c}81 / 83 \\
\mathrm{p}\end{array}$ \\
\hline $\begin{array}{c}\text { - \% chronische aandoeningen } \\
\text { werklozen }\end{array}$ & 18 & & 18 & & - \\
\hline $\begin{array}{l}\text { werkenden } \\
\text { - frequentie doktersbezoek }\end{array}$ & 20 & & 27 & & - \\
\hline werklozen & 2.5 & - & 1.1 & .02 & .02 \\
\hline $\begin{array}{l}\text { werkenden } \\
\text { - lichamelijke klachten }\end{array}$ & 1.9 & & 4.1 & & .05 \\
\hline werklozen & 3.9 & - & 3.3 & - & - \\
\hline $\begin{array}{l}\text { werkenden } \\
\text { - beoordeling gezondheld }\end{array}$ & 6.1 & & 5.4 & & - \\
\hline werklozen & 3.9 & - & 3.9 & - & - \\
\hline $\begin{array}{l}\text { werkenden } \\
\text { - } \% \text { medicijn gebruik op } \\
\text { elgen initiatief }\end{array}$ & 3.9 & & 3.9 & & - \\
\hline werklozen & 59 & - & 23 & .09 & .03 \\
\hline werkenden & 53 & & 53 & & - \\
\hline
\end{tabular}

*: 1 zeer slecht

$3=\operatorname{mat} \mathbb{g}$

$5=$ zeer goed 
Werklozen en werkenden komen overwegend in gezondheid overeen. Waar er sprake 1 van verschillen (frequentie doktersbezoek en het percentage gebruikexs wan medicijnen op eigen initiatief) blijken deze herleid te kunea worden tot veranderingen gedurende de periode 1981/1983.

werklozen bijken vergeleken met werkenden:

- In 1983 minder frequent de dokter te bezoeken. Dit verschil vloeit voort uit een daling in doktersbezoek van werklozen tussen 1981 en 1983 en ten stijging in doktersbezoek van werkenden in dezelfde periode;

- In 1983 eveneens een lager percentage gebrukers van medicijmen op eigen intidatief te amvatten. Dit verschil hangt samen met een dallng van het percentage gebrulkers onder werklozen in de periode tusser 1981 en 1983.

Concluderend: bij een langere duur van het niet werken blijken werklozen minder valk de dokter te raadplegen terwijl het percentage ondex hen dat medicijnen gebrulkt daalt.

\subsubsection{Gezondheidsopvattingen}

In de volgende tabel staan de resultaten inzake gezondheidsopvattingen vermeld.

Tabel 18.6 Vergelijking gematchte paren werklozen en werkenden naar gezondheldsopvattingen over 1981,1983 en $181 / 183 \quad(N=17$ paren).

$81 \quad$ p $83 \quad p \quad \begin{gathered}81 / 83 \\ \text { p }\end{gathered}$

Belang gezondheid*

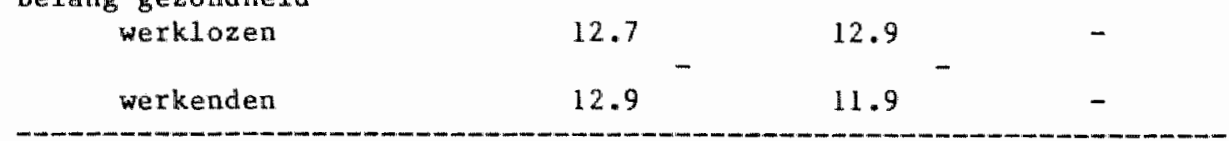

*: $3=1 \mathrm{aag}$

$15=\operatorname{hoog}$

Uit tabel 18.6 blijkt dat werklozen en werkenden onderling geheel overeen komen in de opvatting over het belang van gezondheid; daarnast vinden we geen veranderingen in de tijd. 
Concluderend: de duur van het niet werken heeft geen inwloed op de opvattingen over het belang van gezondheid.

18.3.3 Riskante gewoonten en oordeel eigen leefwijze

In tabel 18.7 geven we de transwersale en longttudinale vergelijking weer van werklozen en werkenden wat betreft riskante gewoonten en de beoordeling van de eigen leefwijze.

Tabel 18.7 Vergelijking gematchte paren werklozen en werkenden naar riskante gewoonten en beoordeling eigen leefwijze over 1981,1983 en $181 / 183(\mathrm{~N}=17$ paren $)$.

$\begin{array}{ccccc}1981 & p & 1983 & p & 81 / 83 \\ p\end{array}$

$\%$ ontbreken 1ichaams beweging werklozen $59 \quad 53$

werkenden

67

\section{3}

40

\% gebruik alcoholische dranken werklozen

$\begin{array}{ll}88 & 82\end{array}$

werkenden

100

93

$\%$ rokers

werklozen

71

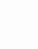

werkenden

53

71

53

$2-$

Werklozen en werkenden komen in riskante gewoonten zowel in 1981 als 1n 1983 overeen. We bespeuren in tabel 18.7 evenmin veranderingen in de tijd.

Wat betreft het oordeel over de elgen leefwijze uinden we een onder- 
1ing verschil in 1983: werklozen rapporteren een miader gezonde leefwille dan werkenden. Dit vergchil vloeit yoort uit een minder positief geworden oordeel van werklozen over de efgen manier van leven in 1983 , ten opzichte van 1981.

Concluderend kunnen we stellen dat de duur van het niet werken onder werklozen gepaard gat met een minder gunstig oordeel over de elgen leefwijze in termen van gezond.

\subsubsection{Part1cipatie}

Werklozen en werkenden blijken onderling niet te verschillen met betrekking tot participatie, noch in termen van het percentage stemmers bij verkiezingen noch wat betreft het percentage mannen dat aangeeft 1id te zijn van kerkgenootschappen (Tabe1 18.8).

Tabel 18.8 Vergelijking gematchte paren werklozen en werkenden naar particlpatie over 1981,1983 en $181 / 83$ ( $N=17$ paren).

$81 \quad \mathrm{P}$

$83 p$

\% stemmers bij verkiezingen

$$
\text { werklazen }
$$

werkenden

\% 1Ldwaatschap kerkgenootschap werklozen werkenden
94

87

65

73
82

93
53

73 


\subsection{Conclusies}

We beginnen met de conclusies op basis van de hypothesen.

1 Gerapporteerde gezondheid

$$
\begin{aligned}
& \text { Hypothese Opmerkingen / } \\
& \text { bevestigd bljzonderheden }
\end{aligned}
$$

Duur nlet werken heeft:

1.1 Bij arbeidsongeschikten een negatief effect op

a de subjectieve gezondheid

$$
\text { meen }
$$

b de objectleve gezondheld

$$
\text { neen }
$$

$\begin{array}{ll}\text { neen } & \begin{array}{l}\text { kleiner \% medicijnge- } \\ \text { bruikers }\end{array} \\ \text { gedeelte- minder doktersbezoek } \\ \text { lijk }\end{array}$

1.3 Bij vervroegd gepensioneerden

a geen effect op de subjectieve gezondheld

b geen effect op de objectieve gezondheid minder lichamelijke klachten

verandert niet

niet getoetst

niet getoetst

Onze hypothesen inzake arbeidsongeschikten en werklozen blijken overwegend verworpen te worden: de duur van het nlet werken heeft nawwe$11 \mathrm{jks}$ effect op de gezondheid. Voor zover er van invloed sprake is $11 \mathrm{jkt}$ deze veeleer tot een (1ets) betere gezondheid te leiden. Op het eerder gemaakte voorbehoud vanwege de ultwal wegens ziekte en overlijden komen we in hoofdstuk 19 terug. 
2 Gezondheidsopvat ingen

Duar ndet werken bewardert belang gezondheld bij

2.1 Arbeldsongeschikten

2.2 werklozen

Duur niet werken heeft

geen invloed op belang

gezondheid bif

2.3 vervroegd gepensioneerden

\section{Hypothese Opwerkingen / \\ bevestigd bijzonderheden}

neen

geen verschi1

neen

geen verschil

Onze kypathesen over de invloed van de duur van het niet werken op het belang dat an gezandheld wordt gegeven, worden verworpen: de dur van het niet werken blijkt geen invloed te hebben op het belang dat arbeidsongeschikten en werklozen aan gezondheld geven. De hypothesen over de beheersingsoriëntatie hebben we niet kunnen toetsen.

3 Riskante gewoonten

\begin{abstract}
Duur niet werken heeft
negatief effect op

riskante gewoonten van
\end{abstract}

3.1 Arbeldsongeschikten

3.2 Werklozen

Duur njet werken heeft

geen negatief effect op

riskante gewoonten van

3.3 vervroegd gepensioneerden
Hypothese Opmerkingen /

bevestigd bijzonderheden

neen

uitgezonderd op roken

neen

niet getoetst

De hypothesen over de invloed van de duur van het niet werken op riskante gewoonten worden verworpen: de duur van het niet werken blijkt geen invloed te hebben op riskante gewoonten van arbeidsongeschikten en werkłozen. De enige uitzondering betreft het percentage rokers: in 
vergelijking met werkenden neemt het percentage rokers onder arbeldsongeschikten niet af. We mogen derhalve annemen dat de duur van het niet werken hieraan debet 1 s.

Letten we op het oordeel over de eigen leefwijze, dan constateren we dat de duur van het zonder werk zijn allén onder werklozen fnvloed blijkt te hebben: zij gaan hun leefwijze als minder gezond beoordelen.

Participatie is alleen gemeten aan de hand van het percentage stemers bij verkiezingen en het percentage dat lid is van een kerkgenootschap.

4 Participatie

Duur niet werken

bewerkstelligt lagere

particlpatiegraad onder

4. 1 Arbeldsangeschikten

4.2 Werklozen

Durur nilet werken beeft

geen invloed op

particlpatiegraad van

4.3 Vervroegd gepensioneerden
Hypothese Opmerkingen /

bevestigd bijzonderheden

meen

neen

Ook de hypothesen over de invloed van de duur van het niet werken op participatie blijken verworpen te worden: de duur van het niet werken heeft onder arbeldsongeschikten en werklozen geen inwloed op het al dan niet stemmen en het al dan niet lid zijn van enig kerkgenootschap.

\subsection{Samenvatt1ng}

Niet werken gedurende een periode van twee jaar leidt bif arbeidsongeschikten tot:

- een afname van het aantal 11chamelijke klachten;

- eenzelfde percentage rokers, terwijl werkenden minder gaan roken;

- eenzelfde percentage dat $11 d$ is van een kerkgenootschap, terwijl dit percentage onder werkenden afneemt. 
Onder werklozen zien we gedurende dezelfde perlode:

- een afname van het doktersbezoek, terwijl onder werkenden sprake is Yan een toename;

- een afname van het percentage mannen dat medicijnen op eigen initiatief slikt;

- een minder positief oordeel over de eigen leefwijze ontstan.

vanwege het te kleine aantal vervroegd gepensioneerden ( 8 ), hebben we hen bulten de analyse gehouden.

over de uftkomsten dient in zoverre een voorbehoud gemaakt te worden dat de ultval vanwege zlekte en overlijden bulten beschouwing gebleven 1s. In het volgende - afsluitende - hoofdstuk komen we hierop cerug. 


\section{Conclusies en Discussie}

Zoals we uit de conclusies van de hoofdstukken 17 en 18 hebben kunnen opmaken, woeten we onze hypothesen over arbeidsongeschikten en werklozen inzake gezondheid grotendeels verwerpen, terwijl we die over veruroegd gepensioneerden als bevestigd moeten beschouwen. De latste categorie hebben we alleen transversal getoetst. Hoewel langdurig arbeidsongeschikten en werklozen op ten varlabele (percentage chronische aandoeningen) een slechtere gezondheid hebben dan de respectievelijke deelcategorleën kortdurig niet werkenden - en op de andere variabelen geen verschillen vertoonden - bleek dat de gezondheld van deze categorieën longitudinaal bezien iets beter werd. Onder arbeidsongeschikten zagen we op ến variabele een verbetering (1ichamelijke klachten), onder werklozen zagen we op twee variabelen een verbetering (doktersbezoek en percentage gebruikers van medicijnen).

Wat betreft de niet werkenden hebben we ons afgevraagd in hoeverre de longitudinale bewindingen geconditioneerd zijn door de uitval van niet werkenden ten gevolge van de matching en de samenstelling van de categorleër naar duur niet werken. We hebben daartoe de te onderscheiden categorieen, gesplitst naar kort- en langdurig niet werkenden zowel onder de gematchte als onder de niet gematchte categorfeên, longltudinal geanalyseerd. Dit leverde vrijwel dezelfde longltudinale gezondheldsprofielen op als hierwor beschreven. We mogen derhalve aannemen dat een selectie ten gevolge van matching en een selectie ten gevolge van een specifleke verdeling van de populatieg naar duur van het niet werken geen noemenswardige rol spelen.

We moeten echter rekening houden met een ander selectie-effect tem gevolge van ultval van respondenten tussen 1981 en 1983 . Het betreft ultwal vanwege zlekte en over 11 jden en vanwege werkhervatting. In de longltudinale analyses $z 1 j \mathrm{j}$ uteraard niet degenen opgenomen die in 
1983 niet geinterviewd konden worden wegens zlekte of overlijden. In hoofdstuk 5 hebben we herop al gewezen. Bij het tweede interview in 1983 bleek dat $13 \%$ wan de arbeidsongeschikten die in 1981 geinterviewd. werden, overleden waren dan wel ziek ( $8 \%$ overleden; $5 \%$ ziek). Van de werklozen bleek $2 \%$ overleden te $2 i j n$, terwil er geen uitval wegens ziekte was. Van de vervroegd gepensioneerden bleek dat $17 \%$ wegens ziekte en overldjden geen tweede keer gejnerviewd kon worden $6 \%$ overleden; $11 \%$ ziek). Daarbij tekenen we nog aan dat becreffende arbeldsongeschikten over alle leeftijden verdeeld waren en dat betrokken vervroegd gepensioneerden in leeftijd warieerden tussen 57 en 64 jaar. Met name de uitwal van de bedoelde arbeldsongeschikten kan een aanzienlijke vertekening opgeleverd hebben wan het longitudinale beeld, zodanig dat er sprake is van een te positief beeld.

Er ls mogelijk ook nog een andere vertekening opgetreden namelijk door de ultval na 1981 van degenen die het werk hervat hebben; dit betreft 12 werklozen en 11 arbeidsangeschikten (zie tabel. 5.2). Zoals we amnemen dat ufrval door ziekte of dood tot een te positief beeld heeft geleid, zo mogen we veronderstellen dat de uitval door werkherwatting tot een te negatief beeld geleld heeft. zo komen we tot de volgende onderstelling: degenen die in 1981 werkloos of arbeidsongeschikt waren en in 1983 betalde arbeid verrichten, hebben een betere gezondheid dan degenen die in 1981 én 1983 werkloos respectievelijk arbeldsongeschikt bleven. Deze onderstelling hebben we getoetst, Dit gebeurde op grond van vijf gezondheldsvariabelen, te weten percentage chrontsche andoentugen, doktersbezoek, 1ichamelijke klachten en beoordeling gezondheld en medicijngebruik op eigen initiatief. De uitkomsten van deze toetsing $z i j n$ als volgt:

- "bl1juend" werklozen hebben in 1981 en 1983 in beperkte mate een slechtere gezondheld dan werkhervatters: In 1981 en 1983 gebruikte onder eerstgenoemden een hoger percentage medicijnen en in 1983 bleken blijvend werklozen darenboven een slechtere beoordeling van de eigen gezondheid te hebben.

- blifvend arbeidsongeschikten bleken eveneens in 1981 en 1983 een slechtere gezandheid te hebben dan werkhervatters: in 1981 gebruikte onder eerstgenoenden een hoger percentage medicijnen, blijuend arbeidsongeschikten hadden bovendien een slechtere beoordeling van 
de elgen gezondheld; in 1983 hadden zij vaker contact met de dokter

en owvatten zif een groter percentage mensen met chronische aandoeningen.

Onze onderstelling kunnen we derhalve als bevestigd beschouwen. Tegelijktijd wordt hiermee de in de literatuur vermelde uitspraak bevestigd dat gezonde of minder ongezonde niet werkenden meer kans tot reintegratie in het arbeldsproces hebben dan niet of minder gezonde nlet werkenden.

Welke bijdrage de afzonderlijke selectie-effecten (zlek of overleden versus werkhervatting) op de longltudinale uitkomst hebben valt niet precies te zeggen. Onder arbeldsongeschikten is de ultval vanwege ziekte of overlijden in leder geval bijna twee keer zo groot als die vanwege werkhervatting (24 versus 11 ). Onder werklozen is de uitval. vanwege werkhervatting 12 keer zo groot als die vanwege ziekte of over11jden ( 12 versus 1$)$.

Wat betekent dit nu voor de uitkomsten van de longitudinalle analyse? We zullen de drie categorieën achtereenvolgens aan bod laten komen. We veronderstellen dat wanneer de werkhervatters in 1983 als werklozen in het onderzoek opgenomen waren het gezondheldsprofiel over twee jaren niet opvallend anders zou zijn dan het beschrevene in het vorige hoofdstuk. Daarnaast zou de ene overledene wanneer deze nog "het leven zou hebben" $\mathbb{i n} 1983$ het profiel waarschijnlijk evenmin opvallend anders gemakt hebben, zelfs wanneer zijn gezondheid op alle variabelen aanzienlijk ongunstiger was.

Gelet echter op het feit dat de eerdergenoemde werkherwatters $z 1 c h \mathbb{A}$ 1983 ook nog onderschelden van de bl1jvend werklozen door een positlever oordeel over de eigen gezondheld, mogen we niet uitsluiten dat werkhervatting een (t1jdelijk?) positieve weerslag heeft op de ervaren gezondheid. De bevinding dat de potentiele werkhervatters als werklozen zich in 1981 al onderscheidden van de blifvend werklozen door een kleiner percentage medicijngebruikers, wijst er echter op dat eerstgenoemden in 1981 al een lets betere gezondheid hadden.

Wanneer we de arbeldsongeschikten onder de loep nemen, dienen we gelet op het grotere aantal ultvallers wegens zlekte en vooral overlijden 
dan wegens werkheryatting, de eerder gedane voorlopige uitspraak dat de gezondheld hetzelfde blijft dan wel lets beter wordt, te relativeren. Er is voldoende reden om de uitspraak te herzien in de steling dat "arbeldsongeschikt 21 jin op den dur tot een slechtere gezondheid letdt* . De vraag 15 echter of deze verslechterde gezondheid het gevolg 18 wan nlet werken, dan wel inherent is an het verloop van het ziekteproces als zodanig. Wanneer we ervan uitgaan dat de gezondheid van werklozen in de loop van de tijd niet verslechtert, en daartoe is voldoende reden waneer we het voorgaande in beschouwing nemen, moeten we tot het tweede besluiten. Het is echter niet onmogelijk dat arbeldsongeschikten het niet werken als een groter probleem beschouwen dan werklozen, ondanks de medische legitimering, omdat zij nawwelijks perspectief hebben oolt tot werkhervating te komen. De oorspronkelijke slechte gezondheid en het gemis aan arbeid kunnen beide bijdragen tot een verdere achteruitgang van de gezondheid.

Hoewel we vervroegd gepensioneerden niet longtudinal gevolgd hebben, dienen we toch even stil te staan bij het, vergelleken met andere categorieën, hoogste percentage ultvallers wegens ziekte tussen " 81 en 183. Dit wijst op een sterk verslechterde gezondheid tussen 1981 en 1983. Dht beeld contrasteert aanvankelijk met de eerdere bevindingen dat vervroegd gepenstoneerden niet verschillen van werkenden. We moeten rekening houden met de mogelijkheid dat het bij transversale meting ontbreken van onderlinge verschillen warschijnlijk ten gevolge van selectie-effect een onjuist beeld geeft van de werkelijkheid. Helaas kunnen we niet vaststellen of de zlektegevallen terug te voeren zljn op VUT-ers dan wel op mannen die om andere redenen eerder met pensloen $z$ ijn gegaan. We kunnen helaas evenmin vaststellen of de ziekte samenhangt met het gemis van arbeld. Dit lastste ligt niet zozeer voor de hand ondat twee jaar na ontslag onder de in hoofdstuk 3 vermelde gedwongen VUT-ers (Philips) blijkt dat "slechts" $13 \%$ het werk mist (Durinck, Kijlstra-ten Thije, 1986). Ondat dit mensen betreft die gedwongen werden van de vur gebruik te maken, veronderstellen we dat dit percentage onder vr1jw111ige vuT-ers nog lager $\mathbb{1} 1 \mathrm{gt}$.

Wanneer we nu terugkeren nar de uitkomsten wan de longitudinale en transversale analyse, komen we tot de volgende conclusie inzake ar- 
beidsongeschikten. De lets slechtere gezondheid van langdurig arbeldsongeschikten ten opzichte van kortdurig arbeidsongeschikten hangt met twee effecten samen:

- een selectie-effect ten gevolge van reintegratie in het arbeidsproces van gezondere arbeidsongeschikten;

- een duur-effect samenhangend met een $1 n$ de tijd verslechterende gezondheidstoestand, die hoogstwaarschijnlijk ziektegebonden is, mar waarbij niet uitgesloten kan worden dat het gemis van arbeid hierop een negatieve invloed heeft.

Wat betreft werklozen concluderen we dat de lets slechtere gezondheld van langdurig werklozen ten opzichte van kortdurig werklozen voorname$1 i j k$ een selectie-effect is ten gevolge van reIntegratie van gezonde werklozen; daarbij sluften wij geensins uit dat reIntegratie zelf bovendien een al dan niet tijdelijk positief effect heeft op de gezondheid.

Over de gezondheldsopvattingen kunnen we kort zijn. Transversaal vonden we onder arbeidsongeschikten en werklozen, in tegenstelling tot onze verwachting, geen verschillen. Wel bleek dat langdurig arbeidsongeschikten meer toevalsgeoriënteerd waren dan kortdurig arbeidsongeschikten (hieromtrent hadden we geen hypothesen geformuleerd). Longitudinaal hebben we alleen kunnen nagaan of het gepercipleerde belang van gezondheid verandert: dit bleek noch het geval bij arbeidsongeschikten, noch bij werklozen.

Riskante gewoonten vormt het volgende onderwerp. Ook de hypothesen over de riskante gewoonten inzake arbeldsongeschikten en werklozen werden grotendeels verworpen, terwijl die over vervroegd gepensioneerden grotendeels bevestigd werden. De enige variabele warop langdurig arbeldsongeschikten en werklozen verschllden van degenen die korte t1jd geen werk hebben, bleek het percentage rokers: onder langdurig niet werkenden rookt een groter percentage dan onder kortdurig niet werkenden. Longltudinaal bezlen vonden we dit verschil alleen en dan nog in vergelijking met werkenden - terug onder arbeidsongeschikten: vergeleken met werkenden bleken zij niet minder te gaan roken. We nemen dan ook aan dat het verschil in percentage rokers 
onder arbeldsongeschikten voormanelljk een selectie-effect is en in mindere mate een gevolg van de duur van het niet werken.

We mogen aannewen dat onder werklozen alleen sprake is van een selectie-effect. Hervoor is geen directe verklaring voorhanden.

In het hoofdstuk riskante gewoonten hebben we ook de variabele beoordeling van de elgen leefwijze gevoegd. Onder werklozen vonden we zowel transversaal als longttudinaal verschillen. Dit impliceert dat de duur van het niet werken ertoe bijdraagt dat werklozen een minder gunstig oordeel over de elgen leefwljze ontwikkelen. We kunen aiet uitsluiten dat hierb1j ook sprake is van een selectie-effect.

Partıclpatle vormde ons laatste onderwerp. Helaas hebben we allén het stemgedrag bif verkiezingen en het 1 idmaatschap van kerkgenootschappen transversaal én longltudinaal kunnen meten. Transversaal bezien bleken hieromtrent geen verschillen te bestaan tussen langdurig en kortdurig arbeidsongeschikten. Longitudinal bezien vonden we éen verschil onder arbeldsongeschikten en wel in relatie tot werkenden: zlj bleken in de loop van de tijd meer dan werkenden zlchzelf nog als lid te beschouwen van enig kerkgenootschap. Omdat het een relatieve verandering betreft hoeft het ons niet te verbazen dat dit verschil transversaal niet teruggevonden wordt.

onder werklozen vonden we én transversaal verschil onder het percentage stemmers bif verkiezingen; onder langdurig werklozen bracht een k1einer percentage zijn stem uit dan onder kortdurig werklozen. Longitudinaal bleek er geen signiflcante werandering te zijn. Het lijkt erop dat er sprake is van een selectle-effect. Niettemin mogen we veronderstellen dat er mogelijk ook sprake is van een causaal effect: onder werklozen zien we een niet significante afname en onder werkenden een niet significante toename in het percentage stemers (tabel 18.8).

De vraag die zich andlent is wat we ons moeten voorstellen bij een selectie-effect; we veronderstellen dat niet stemmen een vorm van (politiek) apathisch gedrag is, welk gedrag samenhangt met het ontbreken van enig vertrouwen in de arbeidsmarkt. Dit laatste brengt met zich mee dat men zich ook niet meer "nodeloos" inspant om werk te vinden. Dit kan er weer toe bijdragen dat de kans om werk te vinden, 
die toch al klein is, vrijwel uitgesloten is. Analoog aan deze redenering zullen de stemers als politiek geInteresseerden actiever zijn en nog wel enig vertrouwen hebben in de arbeldsmarkt met als gevolg dat zif meer "werkzoek gedrag" vertonen en mogelijk ook werk vinden. Een en ander sluit niet uit dat er reele gronden kunnen $2 \mathrm{j} \mathrm{j}$ op grond waarvan werklozen wel of niet apathisch zijn. Het zou gelet op de arbeldsmarkt naIef $z 1 j n$ om het al dan geen werk vinden uitsluitend te verklaren vanult de theorle van de "self fullfilling prophecy". Tot slot wijzen we op het transversaal gevonden verschil onder werklozen in de omgangsfrequentie met familleleden: langdurig werklozen hebben minder frequente omgang met familie dan kortdurig werklozen (zoals eerder gesteld kunnen we longitudinaal bezien hierover geen uitspraak doen). De enig mogelijke verklarling die we hiervoor kumnen geven is dat langdurig werklozen meêr dan kortdurig werklozen geneigd zljn contacten te vermijden om de confrontatie met het werkloos zijn ult de weg te gaan ("Heb je nog geen werk gevonden?"). Een vriendenof kennissenkring kan men wel veranderen indien men zich als werkloze niet geaccepteerd voelt. De kring van familieledem is niet of moeilijker te veranderen; de meest voor de hand liggende reactie bij ongewenste contacten met familie is vermijidingsgedrag. 

Deel V: Afsluiting

20. Conclusies en Nabeschouwing

21. Samenvatting

Summary 



\section{Conclusies en Nabeschouwing}

In het onderhawige onderzoek is een vergelijking gemaakt van niet werkende arbeidsongeschikte, werkloze en vervroegd gepenstoneerde mannen onderling en wet werkende mannen naar gezondheid en leefwijze. Het doel van dit onderzoek was vast te stellen in hoeverre genoemde categorieën onderling verschillen in gezondheld en leefwijze. Tevens waren we geinteresseerd in de vraag in hoeverre de duur van het niet werken de gezandheid en de leefwijze beĩnvloedt.

Teneinde de vraagstelling zo zuiver mogelijk te kunnen beantwoorden, hebben we de volgende overgangscategorieën tussen niet werkende en werkende mannen uitgesloten:

- zij die betaalde arbeld verrichten en drie maanden of langer ziek zijn;

- arbeldsangeschikten, werklozen en vervroegd gepensioneerden die zowel een uitkering genieten als een (deeltijd)baan hebben.

Op deze wijze kunnen de gevonden verschillen in gezondheid en leefsituatie herleid worden tot het onderscheld niet en wel werken. Werken is hierbij synoniem aan het verrichten van betaalde arbeid in lowndienst of als zelfstandige.

Dit brengt met zich mee dat:

- de steekproef werkenden mogelijk lets gezonder 1 s dan de totale populatie werkenden;

- de steekproef niet werkenden mogelijk lets ongezonder is dan de totale populatie nlet werkenden.

Aan de resultaten van dit verslag 11 ggen twee onderzoeken ten grondslag:

- een landelijk representatief panelonderzoek in 1981 en 1983 onder niet werkenden en werkenden;

- een onderzoek in een aantal huisartsprakt1jken in Limburg, behorend tot een gezondhe1dscentrum. 
Het eerate onderzoek is opgezet en ultgevoerd om inzicht te verkrijgen In de gezondheid en leefwijze van de Nederlandse bevolking. Alle resultaten van deze dissertatie, uitgezonderd die van hoofdstuk 9 , berusten op secundaire analyse van gegevens uit dit panel. Het tweede onderzoek, door onszelf opgezet en uitgevoerd, diende om uit te zoeken of de door hutsartsen vastgestelde gezondheld van niet werkende en werkende mannen afwijkt van de door wergelijkbare mannen gerapporteerde gezondheid.

In onze onderzoeksresultaten komt dudelijk naar varen dat arbeidsongeschikten vergeleken met werklozen, veruroegd gepensioneerden en werkenden een intrinslek slechtere gezondheid hebben. Daarnaast blijkt dat werklozen, vervroegd gepensioneerden en werkenden in gezondheid nagenoeg overeenkomen. Deze gegevens gelden zowel voor 1983 als 1981 . Aan de resultaten van de vergelijkingen ligt een statistische correctie ten grondslag op de ondexlinge verschillen in leeftijd, sociaaleconomische klasse en burgerlijke staat. Waar het de vergelijkingen tussen de drie categorieën niet werkenden betreft, is ook gecorrigeerd voor verschillen in de duur van het niet werken. Analyse van de onderzoeksgegevens met behulp van clusteranalyse, waarbij de eerdergenoemde correcties niet zijn toegepast, leidt tot dezelfde conclusies. Arbeidsongeschikten enerzijds en vervroegd gepensioneerden en werklozen anderzijds blifken derhalve geen uitwisselbare categorieën te zijn. Wel blijkt ult de clusteramalyse dat het percentage ongezonden onder de vervroegd gepensioneerden (38\%) hoger is dan onder de werklozen $(27 \%)$. Het $1 \mathrm{igt}$ voor de hand dat dit verschil herleid kan worden tot het verschll in leeftijd tussen beide categorieën. De door ons uitgevoerde discriminantanalyse bevestigt dit.

De gegevens van huisartsen over de gezondheid van niet werkenden en werkenden verschillen niet van de resultaten uit de steekproef: de via interviews verkregen resultaten (gerapporteerde gezondheid) komen overeen met de resultaten op basis van door huisartsen in medische dossiers vastgelegde gegevens over de gezondheid. Er is derhalve geen sprake van "cognitieve trucage"', hetgeen wil zeggen dat arbeidsongeschikten zlch niet "klageriger" en dat werklozen zich niet "flinker" voordoen dan hun gezondheid rechtvaardigt.

We dienen ons hierbij te realiseren dat het landelijk panelanderzoek en de praktljkstudie weliswar dezelfde categorieèn arbeidsongeschik- 
ten, werklozen, vervroegd gepensioneerden en werkenden betreft, war niet dezelfde personen. Dok al zou de limburgse populatie in gezondheid afwijken van de landelijke steekproefpopulatie, dan nog is er geen reden te veronderstellen dat de door vergelifking verkregen profielen inzake de gerapporteerde en inzake de door artsen vastgestelde gezondheld niet naast elkaar gelegd zouden nogen worden. We zijn immers nagegaan of de onderlinge verschillen en overeenkomsten tussen eerdergenoemde categorieën binnen de landelijke steekproefpopulatie afwijken van de onderlinge verschillen en overeenkomsten tussen dezelfde categorieën binnen de praktijkpopulatie. Dat wil zeggen dat wanneer Limburgers gezonder of ongezonder zijn dan de getiddelde Nederlander, dit voor alle Limburgse categorieën niet werkenden en ook voor Limburgse werkenden zou gelden. Een dergelijke systematisehe vertekening kan thet vergelijkingsprofiel niet verstoren. Wietemin verdient het aambeveling ow onze eerdergenoemde uitsprak dat de gerapporteerde gezondheid niet verschilt van de door huisartsen vastgestelde gezondheid, te toetsen onder dezelfde personen behorende tol: de drie onderscheiden categorieën niet werkenden en werkenden.

Wat betreft de samenhang tussen de duur van het ndet werken en gezondheld blijkt het volgende.

Transversaal bezien hebben langdurig werklozen en arbeldsongeschikten een iets slechtere gezondheld dan de respectievelijke deelcategorieën die korte tijd zonder werk zijn. Tussen lang- en kortdurig werklozen en arbeidsongeschikten blijkt éen verschil: langdurig niet werkenden omvatten een groter percentage personen met chronische aandoeningen. op grond hiervan mogen we concluderen dat langdurig werklozen een suboptimale gezondheid hebben; we spreken van suboptimaal ondat zij niet echt verschillen van werkenden. Langdurig arbeidsongeschikten zijn nog lets ongezonder dan arbeidsongeschikten die korte tijd geen werk meer hebben. Onder de vervroegd gepensioneerden vinden we geen verschillen tussen degenen die lange tijd en degenen die korte tijd zonder werk zijn.

Vanuit een longitudinal gezlchtspunt hebben we geconstateerd dat de gezondheld van arbeldsongeschikten en werklozen die in 1981 en 1983 geinterviewd zijn een lichte tendens tot verbetering vertoont. Gelet echter op de relatief grote uitval tusisen beide fiaren onder arbeidsongeschikten, vooral vanwege overlijden, moeten we concluderen dat de 
gezondheld van arbeldsongeschikten in de loop van de tijd slechter wordt. Omdat we ook onder werklozen in de loop van de tijd een lichte verbetering in gezondheld vaststelden, en bij hen de uitval wegens overlifden zeer gering is (ến respondent), nemen we aan dat werkloos zijn geenszins de gezondheid negatief beinvloedt. Van uitval wegens ziekte bleek geen sprake. We mogen derhalve aannemen dat de achteruitgang in gezondheid van arbeidsongeschikten niet het gevolg is van het zonder werk $z 1 \mathrm{jn}$, maar veeleer samenhangt met een aan de zlekte autonoom werbonden proces.

We stelden tevens vast dat degenen die over de periode 1981-1983 als arbeldsongeschikten en werklozen zonder werk bleven, een slechtere gezondheld hebben dan de arbeldsongeschikten en werklozen die tussen 1981 en 1983 het werk hervatten. Dat wil zeggen dat tegenover de ultval wegens ziekte of overlijden een ultval staat wegens werkhervatting van meer gezonde werklozen of minder ongezonde arbeidsongeschikten. Het aantal uitvallers onder arbeldsongeschikten vanwege ziekte of overlifden bleek twee keer zo groot als het aantal uitvallers ten gevolge van werkhervatting. Dit bracht ons tot de voorgaande uitspraak dat de gezondheid van arbeidsongeschikten verslechterd is; het gezondheldsniveau zou nog slechter geweest zijn als de uftvallers wegens ziekte en overlijden ook in de longitudinale analyse opgenomen geweest. waren.

Onder werklozen was de verhouding omgekeerd: 12 werkhervatters tegenover I overledene. Niettemin is de gezondheid van de zonder werk blijwende werklozen toch nog iets verbeterd. Mogelijk vloeit dit voort ult een voortschrljdende aanpassing aan of berusting in het werkloos zijn.

Gelet op de werkhervatting tussen 1981 en 1983 van gezondere werklozen en minder ongezonde arbeidsongeschikten ligt het voor de hand te veronderstellen dat een minder goede gezondheld van werklozen en een grotere ongezondheld van arbeidsongeschikten de kans op reIntegratie in het arbeldsproces verklelnt. Het langs transwersale weg gevonden verschil tussen lang- en kortdurig werklozen dient dan ook vanuit dit perspectief verklaard te worden. Het gevonden verschil tussen lang- en kortdurig arbeidsongeschikten hangt zowel met deze selectie, als uet de duur van de zlekte en mogelijk de duur van het niet werken samen.

Met de uitspraak dat werkloosheld op den dur niet tot ongezondheid leidt, kunnen en willen we uiteraard geen afbreuk doen aan het mense- 
lijk leed dat met werkloos zijn gepaard kan gaan. Gelet op de ard van de variabelen warmee we gezondheid gemeten hebben en op grond warvan we tot deze uitspraak gekomen zijn, kunen we niet uitsluiten dat de mentale gezondhela wêl negatief beInvloed wordt. Het medicijngebruik in termen van slaaptabletten, tranquililizers enzavoort, wijst echter niet in deze richting, mar kan dit geenszins uitsluiten. Aan de andere kant zagen we wel dat werklozen op den duur de eigen leefuljze als winder gezond gingen beoordelen. Het ligt niet direct woor de hand dat dit wijst op een slechter wordende mentale gezondheid. (Op het onderwerp "oordeel over de eigen leefwijze" komen we later in deze nabeschouwing terug). Uiteraard kunnen onze bevindingen niet uitsluiten dat, wanneer niet werkenden in de toekomst (nog) minder financiële middelen toegewezen krijgen, niet werken via armoede wel een effect kan hebben op gezondheid. Evenmin kunnen we uitsluiten dat er specifieke subgroepen werklozen zign bij wie het niet werken wể, en bij wie dit gén negatief effect op de gezondheld heeft.

Hoewel we vervroegd gepensioneerden niet longltudinal gevolgd hebben, dienen we toch even stil te staan bij het opwallend (hoogste) percentage uitvallers onder hen wegens ziekte tussen 181 en 183. Dit wijt

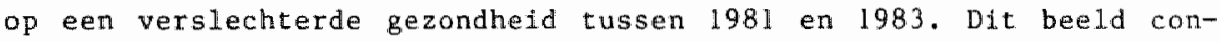
trasteert met de eerdere bevindingen dat vervroegd gepensioneerden nlet verschillen van werkenden. We moeten rekening houden met de mogelfjkheid dat de transversale bevinding dat er niet sprake is van onderling verschil door specifieke selectie een onjuist beeld geeft. Helaas kunnen we niet waststellen of de ziektegevallen terug te voeren zijn op VUT-ers dan wel op mannen die om andere redenen eterder met pensioen zijn gegaan. Uit de resultaten van elders verricht longitudinaal onderzoek onder VUT-ers, mogen we aannemen dat bij hen ziekte niet samenhangt met het gemis van arbeid (Durinck, Kijlstra, Ten Thi je, 1986).

De uftkomsten van de clusteranalyse geven anlefding in deze beschouwing even stil te staan bij het thema verborgen werkloosheid en verborgen arbeidsongeschiktheid. In deze context gat het niet on de vraag hoeveel potentlële arbeldskracht aanwezig is onder het bestand trekkers van arbeidsongeschiktheidsuitkeringen. Wetende dat slechts $10 \%$ tot $15 \%$ van de arbeidsongeschikten geen enkele restcapaciteit heeft, mogen we aannemen dat de hoeveelheld potentiële arbeidskracht 
aanzienlijk is (Hunfeld, 1980). Het gat ons vooral on de 1 th hoof 3 vermelde uitsprak van Van de Bosch en Retersen warbij gesuggereerd wordt dat circa eén derde van de arbeidsomgeschikten op basis van hun gezondheld ten onrechte een arbeidsongeschiktheidsultkering heeft. Overigens stelt de overheid, volgens Hermans et al. (1986), dat de werkloosheldscomponent in de arbeidsongeschiktheidsregelingen structureel $50 \%$ van het aantal uttkeringsdagen bedraagt. We wijzen daarom op het relatief lage percentage (van 17\%) gezonde mannen onder de arbeldsongeschlkten. Tevens wijzen we op het relatief hoge percentage van $27 \%$ ongezonde mannen onder de werklozen.

Hoewel we geenszins stellen dat zowel gezonde arbeidsongeschikten en verborgen werklozen als zieke werklozen en verborgen arbeidsongeschikten synoniemen $z i j n$, verdienen deze twee onderscheiden getallen bijzondere aandacht.

Zo het om wat voor reden dan ook polltiek gewenst blifft verborgen werkloosheid onder arbeidsongeschikten op te sporen, verdient het evenzo overwegling, om redenen van matschappelijke rechtvaardigheid, werklozen te screenen op "werborgen arbeidsongeschiktheid". De verborgen arbeidsongeschiktheid onder de werklozen zou wel eens een grotere omvang kunnen hebben dan de verborgen werkloosheid onder de arbeidsongeschikten.

De uftkomsten van de eerste screening op verborgen werklozen onder arbeidsongeschikten onder de 30 jaar bevestigt tot nog toe de vanuit professlonele kringen woorspelde sterke overschatting van de kant van de overheid (Hermans, Sas, Schraven, 1986). Volgens een krantenpublicatle op basis van nieuwste GMD cljfers heeft de herkeuring ertoe geleld dat $14 \%$ de uitkering helemal verliest, terwij1 $11 \%$ nog slechts een gedeeltelijke ultkering krijgt (Volkskrant, 21 juli 1988). Overigens kwam zowel in deel II van dit onderzoek als in een onderzoek van de GMD naar voren dat er onder arbeidsongeschikten geen relatie is tussen leeftljd en gezondheid (GMD, 1987). Voorzover de beslissing met betrekking tot genoumde leeftijdsgrens berust op de vooronderstelling dat deze relatie er wEl 1s, 11 jkt deze vooralsnog onjuist te zijn. In de clusteranalyse kwam ook nar voren dat het percentage $z$ ieke werklozen vrijwel gelijk is aan het percentage zieken onder de werkenden. Dit ligt in het verlengde van onze eerdere conclusie, op basis van een andere analysetechniek, dat werkenden en werklozen niet in gezondheld verschillen. Wanneer we de "werkenden" die drie maanden of 
langer ziek zijn mede in anze analyse betrokken hadden, was het percentage ongetwijfeld hoger witgekomen. Dat neemt niet weg dat in geval van $27 \%$ zieke werkenden, niet duidelijk is welk deel ervan op het werk afwezig is wegens ziekte en welk deel tot de categorie zieke doorwerkers behoort. Zolang men als zieke het vermogen heeft om gezondheidsstoornissen zodanig te hanteren dat men in de werksituatie naar behoren kan blijven functioneren, kan men tot een afwegingsproces blijven komen en de definitieve keuze door te werken effectueren.

We veronderstellen dat een aanzlenlijk deel der zieken (te) lang blijft doorwerken of vanwege identificatie met het werk, bedrijf, collega's of vanwege de angst voor ontslag of voor verregaande verzuimbestrijdende matregelen. Hoewel een werknemer kan menen naar behoren te functioneren, is het denkbar dat vanuit de bedriffsleiding hierover anders gedacht wordt. Dit kan weer tot verzuimstimulerende matregelen leiden door betrokkene aan te sporen gebruik te maken van de ziektewet of de arbeidsongeschiktheidsregeling. Kennelijk gat "de kruik net zo lang te water tot hij barst" : ult een rapport van de GMD blijkt dat maar liefst 50\% van de in 1985 tot de WAO toegetredenen, rapporteerden winder dan 2 weken verzuimd te hebben in het laatste jaar voor de WAO toetreding. Het is met name de oudste leeftijdcategorle (55-64 jaar) die het laagste zlekteverzuim vertoonde en minder vaak melding makte van aantasting van prestaties door klachten (GMD, 1987). Gelet op de door ons gehanteerde matstaven om mensen in te delen naar ziek en gezond, mogen we aannemen dat "onze" zieke werkenden aanienlijke risico's lopen arbeldsongeschikt of werkloos te worden.

Behalve naar gezondheld, hebben we ook onderlinge vergelijkingen gemakt naar gezondheidsopvattingen en leefwijze. Wat gezondheidsopvattingen betreft, onderscheiden arbeldsongeschikten zich net als bif het thema gezondheld van overige niet werkenden en werkenden. Zif blifken minder dan anderen de menling toegedaan dat zij hun elgen gezondheld kunnen beinvloeden (interne orlëntatle), terwifl zij méer dan anderen de opvatting huldigen dat machtige anderen, vooral artsen, hun gezondheld kunnen beinvloeden (externe oriëntatie). Gelet op hun afhanke11 jkheid van artsen hoeft dit ons niet te verbazen.

Vervroegd gepensioneerden komen gedeeltelijk met werkenden overeen, terwijl werklozen niet verschillen wan werkenden. 
In het oordeel over de eligen leefwijze blijken arbeidsongeschikten en langdurig werklozen zich te onderscheiden van de overïge (deel)categorleën nlet werkenden, door een negatlever oordeel over de eigen leefwijze; zij komen hierin wet werkenden overeen (1). Kennelijk brengt arbeldsongeschikt en langdurig werkloos zijn, alsmede het verrichten yan betaalde arbeid, een leefsituatie met zich mee warin wen onvoldoende komt tot een leefwljze die men zelf gezond acht. We veronderstellen dat het in vergelijking met dat van vervroegd gepensioneerden minder positieve aordeel van arbeldsongeschikten en langdur1g werklozen ook samenhangt met hun groter aantal riskante gewoonten. Overigens hebben arbeldsongeschikten en werklozen gedeelte$11 \mathrm{jk}$ ook meer riskante gewoonten dan werkenden.

Kennelijk liggen er bij werkenden enerzijds en bij arbeidsongeschikten en langdurig werklozen anderzijds twee onderscheiden factoren ten grondslag aan hetzelfde minder positieve oordeel: bij werkenden vooral de arbeldsdruk en bij genoemde niet werkenden een minder goede gezondheld, riskante gewoonten en hoogstwaarschijnlijk het gemis aan een zinwolle structurering van het dagelijks leven (Knibbe, 1984).

Longltudinal bezien leidt een langere duur van het niet werken niet tot meer riskant gedrag. Omdat langdurig arbeidsongeschikten, zeer gedeeltelijk, en langdurig werklozen, gedeeltelijk, wel méer riskante gedragingen vertonen dan de respectievelijke deelcategarleën niet werkenden die korte tijd zonder werk zijn, lijkt het dat niet alleen een minder goede gezondheld, maar ook riskant gedrag een selectieeffect heeft: mensen met xiskante gedragingen hebben minder kans op reintegratie $\mathbb{i n}$ het arbeidsproces.

Tegen de achtergrond wan het voorgaande sluiten we niet uit dat een minder goede gezondheld gepard gat met riskante gewoonter.

Het 45 inmiddels duidelijk dat arbeidsongeschikten niet alleen een risicogroep $z 1 \mathrm{jn}$ vanwege hun slechte gezondheid, maar ook vanwege hun riskante gewoonten. Gelet op hun gezondheidsopvattingen, waaruit blifkt dat zif minder dan anderen van mening zijn hun gezondheid zelf te kunnen beInvloeden, mogen we annemen dat zij niet gemakkeiljk uit zichzelf ertoe komen de riskante gedragingen te stoppen. Mogelijk zijn artsen meer de aangewezen personen om dit te beinvloeden, gezien de hoge externe orlëntatie van arbeidsongeschikten. We zagen echter in hoofdstuk 9 dat huisartsen onder arbeidsongeschikten niet méér riskan- 
te gedragingen signaleerden dan onder werkenden. We nemen aan dat huisartsen hierop niet bijzonder alert zijn bij arbeldsongeschikten.

Een deelverklaring voor verschillen in oordeel over de eigen leefwijze vanut verschillen in sociale participatie ligt niet zozeer voor de hand: van opvallende verschillen in participatie tussen de drie nlet werkende categorieën enerzijds en tussen niet werkenden en werkenden anderzijds is geen sprake. Bovendien blijken de gevonden verschillen niet in dezelfde richting te wijzen.

Onze bevindingen contrasteren met die van het Sociaal Cultureel Planbureau. Het SCP stelt dat niet werkenden vergeleken met werkenden minder contacten onderhouden met vrienden en familieleden; dit zou zich bij arbeidsongeschikten geprononceerder voordaen dan bij werklozen (Becker, Vink, 1984). In ons onderzoek komt nar woren dat arbeidsongeschikten en werklozen, vergelleken met werkenden, weliswar minder vaak lid zijn van verenigingen/clubs, maar $z 1 j$ blijken in gelijke mate als werkenden, arbeidsongeschikten zelfs vaker, contacten te hebben met vrienden, kennissen en familieleden.

De in vergelijking met werkenden geringe politiek belangstelling van arbeidsongeschikten en werklozen zoals door het SCP gesignaleerd, komt wel overeen met onze bevindingen. Transversaal blijkt dat onder langdurig werklozen een kleiner percentage stemt dan onder kortdurig werklozen; longitudinal zien we een tendens tot minder stemmen. Onder arbeidsongeschikten zien we echter geen samenhang tussen duur van het niet werken en stemgedrag. We mogen derhalve concluderen dat beide categorieën $z$ lich minder dan werkenden met het matschappelijk politiem ke bestel identificeren. Het 1 ijkt erop dat bij werklozen het vertrouwen in de politieke organisatie in de loop van de tijd minder wordt. Wat betreft het lidmaatschap van kerkgenootschappen springen alleen de werklozen erult in relatie tot arbeldsongeschikten: werklozen blijken verhoudingsgewijs minder vaak lid te $z i j n$. In vergelifking met werkenden onderschelden werklozen zich evenmin als arbeldsongeschikten en vervroegd gepensioneerden. Hanneer we de arbeldsongeschikten in de tijd volgen, zien we dat het percentage mannen dat rapporteert 1 id te zijn van een kerkgenootschap niet terugloopt, terwijl dit bijwerkenden wel het geval is. Kennelijk heeft het lidmaatschap van kerkgenootschappen voor werklozen minder betekenis dan voor arbeidsongeschikten; daarnaast heeft het 11 dmatschap zeker op den duur relatief meer bete 
kenis voor arbeidsongeschikten dan voor werkenden. Vanuit welke achtergronden de verschilien te verklaren $z i j n$, is niet zonder meer duldelijk.

We kumen ons voorstellen dat de eens door de socloloog Parsons geformuleerde rechten (en plichten) van zieken, voortkomend vanult de christel1jke moraal, binnen kerkgenootschappen sterker onderkend worden dan erbuften. Tegenover de aan arbeidsongeschikten op basis van hun zlekte mogelijk toegekende rechten (of gunsten) op extra zorg en aandacht en ontheffing van sociale verplichtingen, zou immers vanuit de kerken de plicht bestaan deze rechten in de praktijk tot uitdrukking te brengen.

Werklozen verkeren wat dat betreft in een ongelijke positie ten opzichte van arbeldsongeschikten, omdat het etiket "ziek" niet op hen van toepassing is. Daarnaast $11 \mathrm{jkt}$ het concurrende etiket "armoede" in Nederland evenmin op hen van toepassing. Zoals we in de Verenigde Staten en Groot Brittanie zien, leidt armoede ook tot extra zorg en aandacht vanuit de kerken. Of dit als recht dan wel als gunst gezien wordt, vanult gevende en ontwangende partij, is ons onvoldoende bekend.

Arbeidsongeschikten blijken op den duur van werkenden te verschillen door een hoger percentage leden van kerkgenootschappen. Ook dit verschil valt mogelifk te verklaren vanuit door arbeidsongeschikten ervaren extra zorg en aandacht.

Werklozen onderscheiden zich zowe 1 in 1981 als in 1983 van werkenden door een - welfswaar niet signiflkant - lager percentage leden. Ondat dit verschil systematisch in dezelfde richting wijst. mogen we hieraan enige betekenis geven. Herklozen ervaren mogelijk een onduldelijke positie blinnen de kerken. Zij worden noch als zlek en noch als arm beschouwd, terwij1 de schuldeloosheid aan het niet werken mogelijk in het gedrang is (Maassen en de Goede 1987).

De schuldvraag zou wel eens gevoed kunnen worden vanuit christelijke (nast burgerlijke) argumenten, dat arbeld een wezenlijke, onmisbare voorwarde is voor het mens-zijn (Beerling, 1964). Vanuit deze interpretatie wordt mogelijk de twijfel gevoed of werklozen echt al het mogelljke doen om betalde arbeid te vinden.

In hoeverre onze veronderstellingen juist zijn, staat te bezien. Verder onderzoek kan hierover meer uitsluitsel geven. 
Gelet op de matschappelijke discussie over de tweedaling van de samenleving, is het van belang vast te stellen in hoeverre er sprake is van scheidslijnen tussen niet werkenden en werkenden. Voor zover er sprake van is, blijken deze per thema te variëren in de mate en in de richting warin de categorieën zich schelden.

Wat betreft gezondheld zien we een duidelijk verschil tussen enerzijds arbeidsongeschikten en anderzijds de overige niet werkenden categorieën en werkenden.

Vanuit het gezichtspunt van gezondheidsopvattingen loopt een scheidsIijn voornamelijk tussen arbeldsongeschikten enerzijds en werkenden anderzijds. Arbeidsongeschikten blijken zich te onderscheiden door een lage interne en een hoge externe beheersingsoriëntatie. Dit is naar wij aannemen het gevolg van de patiëntencarriere. Een dergelljke carriere brengt hen kennelijk tot de opvatting dat zij zelf weinig aan hun gezondheid kunnen doen, maar dokters veel.

Letten we op de riskante gewoonten dan zien we tussen arbeldsongeschikten en werklozen enerzijds en werkenden anderzijds een gedeeltelijke scheidslijn lopen: werkenden vertonen minder riskante gewoonten. Vanuit het gezichtspunt "oordeel eigen leefwijze" kunnen we eveneens een $11 j n$ trekken tussen enerz1jds arbeidsongeschikten en werkenden en anderzijds vervroegd gepensioneerden en werklozen.

Wat betreft participatie is er sprake van zeer gedeeltelijke scheidslijnen: arbeidsongeschikten en werklozen onderscheiden zich voorname$11 \mathrm{jk}$ van werkenden, en niet van vervroegd gepensioneerden, door een kleiner percentage personen dat stemt bij verkiezingen en contacten heeft met (ex-) collega's én een kleiner percentage dat lid 1 s van verenigingen/clubs.

De meest in het oog springende scheidslijnen achten we die betreffende gezondheid en gezondheidsopvattingen. Arbeldsongesichikten, zijnde de enige echt ongezonde categorie, blijken de mening toegedaan dat zijzelf niet en artsen als machtige anderen wel de gezondheld kunnen beInvloeden. Dit laatste kan gelet op hun gezondheld begrijpelifk zijn. Hoewel zij relatief vaak de dokter bezoeken, lijkt het erop dat. in het bezoek arbeidsongeschikt zifn als persoonlijke beleving en in zijn matschappelijke consequentles niet of nauwelifks ter sprake komt. Dat het nlet werken voor hen, en voor werklozen, een probleem 1s, komt 1 n de literatuur duidelijk naar voren (Merens-Riedstra, 
1981). In de probleemlijsten van de huisartsen komt het probleem "geen werk" slechts ến keer voor. We mogen dan ook aannemen dat de relatie niet werken en gezondheld niet direct binnen het aandachtsveld van de hulsarts valt. Deze bevinding contrasteert met de huisartsgeneesicundige takopvatting van integrale continue en persoonlijke zorg. Huisartsen zouden kunnen opmerken dat patiënten problemen rondom het niet werken zelf nlet ter sprake brengen. Hoogstwaarschijnlijk doen patienten dit niet ondat $z i j$ menen dat (huis)artsen dit niet relevant achten; zo zij denken dat $z i j$ het wel van belang achten om hieraan aandacht te besteden, verwachten zij waarschijnlijk dat de (huis)arts hlermee niet uit de voeten kan. Deze perceptie weerhoudt hen ervan de psychosociale problemen van niet werken, voortvloeiend uft of samenhangend met de ziekte te bespreken met huisarts, specialist en wijkverpleegkundige. Deze perceptie vinden we terug bij patiënten met chronische aandoeningen (bijvoorbeeld diabetes en reuma), waar het gaat of psychosociale problemen samenhangend met of voortvloeiend uit de ziekte (Kleln Tesselink, Sonmemans, 1985; van der Horst e.a., 1986).

Dat het probleem arbeldsongeschiktheid weinig besproken wordt, zou onder andere daarmee samenhangen dat huisarts en patiënt niet gewend zijn om problemen rond werken en niet werken met elkaar te bespreken (Knottnerus, 1985). Misschien verklaart dit ook wel het geringe aantal contacten tussen huisartsen en werklozen; de werkloze heeft minder gauw dan de arbeidsongeschikte een medisch alibi om bimnen te komen am vervolgens ook desgewenst het niet werken ter sprake te brengen. Op de probleeml1fsten van werkloze patiënten komt het probleem "niet werken" trouwens geen enkele keer voor.

Het $1 s$ in dit kader van belang erop te wijzen dat de arbeldsongeschikten en (langdurig) werklozen van de huisarts niet zozeer vragen am de oplossing van allerlei problemen, als wel "het geven van viertrouwen an lemand die soms in alle opzichten vertrouwen en zekerheid mist" (Jordans, aangehaald in Knottnerus, 1985).

of hulsartsen vanuit deze optiek arbeidsongeschikten benaderen is niet bekend. Gelet op de uitkomsten in de (schaarse) literatuur hierover ligt det niet voor de hand (Kagenaar e.a., 1985). 


\section{Samenvatting}

De doelstelling van deze studie is vast te stellen in hoeverre arbeldsongeschikte, vervroegd gepensioneerde en werkloze mannen onderling en in vergelijking met werkende mannen verschilien in gezondheid en leefwijze.

Een nevendoelstelling van dit onderzoek is inzicht te verwerven in de relatie tussen de duur van het niet werken enerzijds en gezondheid en leefwijze anderzijds.

Deze studie bestaat ult vijf delen. Elk deel begint met een inleiding en wordt afgesloten met conclusies.

Deel I is inleidend van karakter (hoofdstuk 1-6). In de delen II, III en IV geven we de onderzoeksresultaten weer.

Deel II (hoofdstuk 7-11) handelt over gezondheid en gezondheidsopvattingen.

In deeI III (hoofdstuk 12-15) schenken we aandacht aan twee aspecten van de leefwijze, namelijk de voor de gezondheld riskante gewoonten en de sociale particlpatie.

In deel IV (hoofdstuk 16-19) bespreken we de samenhang tussen de duur van het niet werken enerzifds en gezondheid, gezondheidsopvattingen, riskante gewoonten en participatie anderzijds. We doen dit aan de hand van een transversale en een longltudinale analyse.

Deel $\mathrm{V}$ vormt het afslultend gedeelte.

In hoofdstuk 2 van deel $I$ wordt het maatschappelijk verschijnsel niet werken beschreven. Aangegeven wordt welke categorieën niet werkenden In de Nederlandse samenleving onderschelden kunnen worden en hoe deze zich in de loop van de tijd ten opzlchte van elkaar en ten opzichte van werkenden naar omvang ontwikkeld hebben. 
Dok bespreken we de verdeling van de beroepsbevolking naar leeftijd en geslacht. Aan de hand van de beschlkbare literatuur gaan we eveneens in op enkele achtergrondkenmerken van de drie categorieän niet werkenden, te weten de verdelingen naar leeftijd, sociaal-economische klasse en provincie. De duur van het niet werken komt eveneens aan de orde.

In hoofdstuk 3 gaan we aan de hand van binnen- en buitenlandse 1iteratuur in op de samenhang tussen niet werken en gezondheid. We bespreken de invloed van ongezondheld op niet werken, dan wel zonder werk geraken, en de invloed van nitet werken op gezondheid.

Het lifkt zeer aannemelifk dat een slechte gezondheid niet alleen tot arbeldsongeschlktheid leidt, maar voor een deel ook tot werkloosheid. Vooral bij reorganisaties blijken minder gezonden grotere kans op ontslag te hebben; bij bedrijfssluitingen lijkt dit niet het geval. Dat een slechte gezondheid tot vervroegde pensionering leidt, wordt niet aangetoond en ligt ook niet voor de hand.

Met betrekking tot de vraag of niet werken tot een slechte gezondheid leidt, lopen de bevindingen in de literatuur nogal uiteen, vooral waar het gaat over de mate waarin de gezondheid negatief beInvloed wordt. Gezondheid blijkt trouwens op vele manieren geoperationaliseerd te worden.

Resultaten van onderzoek ap hoog geaggregeerd niveau hebben bijgedragen tot een methodologische en inhoudelifke bezinning op de relatie niet werken en gezondheid. Er blijkt behoefte aan drie "typen" anderzoek, b1j voorkeur op \#ndividueel niveau, om hierin inzicht te krijgen:

- explorerend-beschrijvend onderzoek on tot ontwikkeling van gedragsmodellen te komen;

- transversaal onderzoek om de samenhang tussen werken en gezondheid te kunnen bestuderen;

- longltudinal onderzoek om duldelijkheid te verschaffen over de causale relatie niet werken en gezondheid.

Langs deze wegen kan ook kennts vergaard worden over varlabelen die tot niet werken en gezondheid predisponeren en over variabelen die de relatie niet werken en gezondheld doorkruisen (zoals riskante gewoonten). 
Voortbouwend op de bevindingen in de voorgaande hoofdstukken vervolgen we in hoofdstuk 4 met de probleemstelling, hypothesen en operationalisering. Voorafgaand aan de probleemstelling, geven we aan de hand van de gedeeltelijk eerder besproken literatur een overzicht van bevindingen en overwegingen die richting en inhoud geven aan het onderzoek.

Ons onderzoek heeft voornamelijk een toetsend en gedeeltelijk een explorerend karakter.

Hoofdstuk 5 omvat de methoden van onderzoek en de beschrijuing en verantwoording van de onderzoekspopulaties. Tevens worden de gebruikte statistische methoden aangegeven.

De dissertatie berust op twee onderzoeken:

1 een panelonderzoek naar de gezondheid en leefwijze van de Nederlandse bevolking van 21 tot 65 jaar. Voor dit panelonderzoek, wamrvoor zowel in 1981 als in 1983 een meting is verricht, is gebruik gemaakt van een gestandaardiseerde vragenlijst;

2 een praktijkonderzoek naar de gezondheld van arbeidsongeschikte, werkloze, vervroegd gepensioneerde en werkende mannen. Vijf huisartsen hebben de gezondheld vastgelegd van de tot hun patientenbestand behorende mannen van 21 tot 65 jaar. Dit gedeelte van het onderzoek diende ertoe om na te gaan of de door respondenten gerapporteerde gezondheid verschilt van de door huisartsen in medische dossiers vastgelegde gezondheid.

In deel II, hoofdstuk 8 , wordt duidelijk dat arbeldsongeachikten een intrinsiek slechtere gezondheld hebben dar werklozen, vervroegd gepensloneerden en werkenden. Laatstgenoemde drie categorieën biljken tevens onderling vrijwel geheel overeen te komen. De hypothesen blijken grotendeels bevestigd te worden. Een bevinding contrasteert met onze verwachting: werklozen hebben géen slechtere subjectleve gezondheid dan vervroegd gepensioneerden en werkenden, mar komen met hen overeen.

Uit hoofdstuk 9 blijkt een grote overeenkomst tussen de door niet werkenden gerapporteerde en de door hulsartsen vastgestelde gezondheid 
van niet werkenden (en wexkenden) op basis van medische dossiers. We hebben geen reden om te twijfelen an de betrouwbarheid van gezondheldsrapportages van mensen over hum elgen gezondheid.

Gezondhe1dsopvattingen komen eveneens in hoofdstuk 8 aan de orde. Onze hypothesen ower de gezondheldsopwattingen met betrekking tot niet werkenden onderling blijken voor meer dan de helft bevestigd te worden. Arbeldsongeschikten blijken, in tegenstelling tot onze onderstelling, niet van werklozen en vervroegd gepensioneerden te verschillen met betrekking tot het belang dat gezondheid woor hen heeft. Evenmin blijken zlj een lagere interne oriëntatie te hebben dan werklozen, terwijl zij met vervroegd gepensioneerden overeenkomen. Arbeidsongeschlkten blijken wel een hogere orlëntatie op artsen als machtige anderen te hebben dan werklozen.

De hypothesen over de vergelijking van niet werkenden en werkenden onderling worden grotendeels bevestigd. Niet werkenden blijken trouwens vaker van werkenden dan van elkaar te verschillen. Opvallend is echter dat arbeidsongeschikten gezondheid niet en vervroegd gepensioneerden gezondheid wêl belangrijker achten dan werkenden.

Arbeidsongeschikten onderscheiden zich in vergelijking tot de andere categorleën niet werkenden het meest uitdrukkelljk van werkenden naar gezondheldsopvattingen: vooral de lagere interne oriëntatie en de hogere oriëntatie op artsen als machtige anderen valt op. Gezien hun afhankelijkheid van het medisch circuit is dit niet verwonderlijk.

Een belangrijk aandachtspunt is de in hoofdstuk 10 besproken consistentle van de onderzoeksbevindingen over de gerapporteerde gezondheid. Vorenstaande resultaten betreffen de gegevens van 1981 . Resultaten uit dezelfde panelstudie uitsluitend over het jaar 1981, leveren eenzelfde profiel op.

De door ons op een andere wijze dan de in hoofdstuk 8 verrichte analyse, namelijk clusteranalyse, bevestigt de eerder gevonden uitkomsten met betrekking tot gezondheld. Opvallend is dat het percentage zieke werklozen hoger is dan het percentage gezonde arbeldsongeschikten. 
In deel III, hoofdstuk 13, blijkt dat, in tegenstelling tot onze verwachting, arbeldsongeschikten (lets) meer riskante gewoonten hebben dan werklozen en verwroegd gepensioneerden. Gelet op hun slechte gezondheid hadden we verwacht dat zij er eerder minder, dan meer riskante gewoonten dan werklozen op na zouden houden. De bevinding dat arbeldsongeschikten mëer riskante gewoonten hebben dan vervroegd gepensioneerden komt met onze verwachting overeen, hoewel wij een groter verschil veronderstelden.

Herklozen en vervroegd gepensioneerden verschillen nawwelijks van werkenden. We hadden onder werklozen mér riskante gewoonten verwacht. We achten het opvallend dat arbeidsongeschikten eerder (iets) mEEr dan (iets) minder riskante gewoonten hebben dan werkenden. Zij blijken niet alleen een risicogroep vanwege hun slechte gezondheld, maar ook vanwege hun ten dele mếr riskante gewoonten (percentage rokers en percentage bij wie regelmatig lichaamsbeweging ontbreekt). Niettemin vinden we onder arbeidsongeschikten een lager percentage gebruikers van alcoholhoudende dranken dan onder werkenden. De "drinkers" onder hen drinken evenveel als de "drinkers" onder de werkenden.

Wat betreft participatie (hoofdstuk 14) zijn de onderlinge verschillen minder groot dan wat betreft riskante gewoonten: de drie categorieën niet werkenden komen overwegend onderling overeen. Het enige opvallende is dat onder werklozen een kleiner percentage lid is van een kerkgenootschap dan onder arbeidsongeschikten.

Wanneer we niet werkenden met werkenden vergelijken valt op dat vervroegd gepensloneerden vrijwel geheel, werklozen gedeeltelijk en arbeidsongeschikten in beperkte mate met werkenden overeenkomen. Binnen alle drie categorleën onderhoudt een kleiner percentage contacten met (ex-)collega's. Opvallend is dat onder arbeldsongeschikten en werklozen een kletner percentage $11 \mathrm{~d}$ is van verenigingen/club en een kleiner percentage bif verkiezingen zijn stem ultbrengt. Vergeleken met werkenden blifken arbeidsongeschikten niet minder frequent maar juist frequenter contacten te onderhouden met vrienden/kennissen en familie en meer uren te besteden aan vereniglngen/clubs. 
Transversaal bezten hebben langdurig werklozen en arbeidsongeschikten - zo blljkt ult deel IV, hoofdstuk 17, - een lets slechtere gezandheid dan de respectievelijke deelcategorieen kortdurig niet werkenden. Lang- en kortdurig vervroegd gepensioneerden verschillen onderling niet. De gezondheid van de arbeidsongeschikten die in 1981 en 1983 geInterviewd $21 j n$, blijkt lets te verbeteren. Wanneer we echter letten op de uitval legens ziekte en overlijden onder de arbeidsongeschikten na 1981 moeten we concluderen dat de gezondheid van arbeidsongeschikten in de loop van de tijd verslechtert. We veronderstellen dat de achteruitgang van arbeldsongeschikten samenhangt met hun ziekte, omdat de gezondheld van werklozen tussen 1981 en 1983 iets verbetert. Voor vervroegd gepensioneerden vinden we transversaal geen verschil. We hebben hen niet in de longitudinale analyse opgenomen vanwege het zeer kleine aantal. Opvallend is dat het aantal vervroegd gepensioneerden dat in de tweede meting niet aan het interview deelnam wegens ziekte, aanzlenlijk groot was. Het ligt niet voor de hand dat dit het gevolg. is van het niet werken, hoewel we dit niet kunnen uitsluiten.

De resultaten van ons onderzoek over gezondheidsopvattingen zijn als volgt: transwersaal vinden we onder arbeidsongeschikten en werklozen, in tegenstelling tot onze verwachting, nauwelijks verschillen. Wel bleek dat langdurig arbeidsongeschikten meer toevalsgeoriënteerd waren dan kortdurig arbeldsongeschikten (hieromtrent hadden we geen hypothesen geformuleerd). Longitudinaal hebben we alleen kunnen nagaan of het gepercipleerde belang van gezondheid verandert: dit bleek noch het geval bij arbeldsongeschikten, noch bij werkiozen.

ook de hypothesen over de riskante gewoonten inzake arbeldsongeschikten en werklozen worden grotendeels verworpen, terwijl die over vervroegd gepenstoneerden grocendeels bevestigd werden. De enige variabele warop langdurig arbeidsongeschikten en werklozen verschillen van degenen die korte tijd geen werk hebben, blijkt het percentage rakers: onder langdurig niet werkenden rookt een groter percentage dan onder kortdurig niet werkenden. Longttudinal bezien vinden we dit verschil. alleen - en dan nog in relatie tot werkenden - terug onder arbeidsongeschikten: vergeleken met werkenden blijken zij niet minder te gaan 
roken. We nemen dan ook aan dat het verschil in percentage rokers onder arbeidsongeschikten voornamelijk een selectie-effect is en in mindere mate een gevolg van de duur van het nlet werken.

We mogen aannemen dat onder werklazen allekn sprake is van een selectie-effect: niet rokers keren waarschijnlijk eerder terug in het arbeldsproces omdat zij naar wij annemen gezonder zijn. Onder riskante gewoonten hebben we ook de varlabele beoordeling van de efgen leefwijze gevoegd. Onder werklozen vinden we zowel transversaal als longltudinaal verschillen. Dit impliceert dat de duur wan het niet werken ertoe bifdraagt dat werklozen een minder gezond oordeel over de eigen leefwijze ontwikkelen.

Participatie is in dit onderzoek zowel transwersal als longitudinal gemeten door middel van het stemgedrag bij verkiezingen en het 1 idmaatschap van een kerkgenootschap. Transversaal bezien blijken hieromtrent geen verschillen te bestaan tussen langdurig en kortdurig arbeidsongeschikten. Longitudinaal bezien vinden we Eén verschil onder arbeldsongeschikten en wel in relatie tot werkenden: $z i j$ blijken in de loop van de tijd minder dan werkenden zichzelf miet meer als $11 d$ te beschouwen van enig kerkgenootschap. Omdat het een relatileve verandering betreft hoeft het ons niet te verbazen dat dit verschil transversaal niet terug gevonden wordt.

Onder werklozen vinden we én transversal verschtl onder het percentage stemmers bif verklezingen; onder langdurlg werklozen bracht een kleiner percentage $z$ jn stem uit dan onder kortdurig werklozen. Longitudinaal bleek er geen significante verandering te zijn. Dit betekent dat er in leder geval sprake is van een selectie effect. Niettemin veronderstellen we dat er daarnaast in mindere mate ook sprake is van een causal effect ten gevolge van het nlet werken: onder werklozen zien we gemiddeld een niet significante afname en onder werkenden gemiddeld een niet significante toename in het percentage stemmers. 


\section{Summary}

The objective of this study was to compare self-reported health, health locus of control, unhealthy habits and social participation in four categories of Dutch men aged between 21 and 65 years, viz. workers (employees and self-employed men), unemployed, early retired (not for reasons of 111 health) and those incapacitated for work. In Eng11sh summarles of Dutch articles and books we often find the term 'arbeldsongeschikten' translated by 'disabled'. We prefer the term 'Incapacitated for work', because the term 'arbeidsongeschikten' encompasses more than people with a clear physical and mental disablement.

More speclfically, we wanted to find out whether non-workers belonging to each of the three categories mentioned, differ from each other and from workers. Especially from a macra-economic point of view it has been stated that there is hardly any distrinction between those incapacitated for work and the unemployed: it has been suggested that a considerable percentage of the incapiacitated are "concealed" unemployed instead of actually being incapacitated for work.

Moreover, we were interested in the relationship between the duration of non-employment on one hand and health locus of control, unhealthy hablts and soctal participation on the other hand. This issue was approached in a transversal and a longitudinal manner.

Chapter two describes the Dutch population in terms of working and non-working, in the sense of having no paid work. It became clear that the number of unemployed and incapacitated men has grown enormously during the last decade. We describe these categories and the early retired in terms of back-ground variables and duration of non-employment. Attention is drawn to the fact that the duration of unemployment has increased sharply over the last few years. 
Chapter three introduces the discussion of the relationship between health and not having a paid job from two points of view:

1 does poor health cause loss of one's job?

2 does the loss of one"s job cause poor health?

On the basis of Dutch and international Iiterature the unemployed, the incapacitated and the early retired are discussed separately, from both points of view.

We conclude that poor health may lead to a status of being incapacitated or a status of being unemployed. The suggestions made by the Ministery of Social Affairs that poor health may also lead to early retirement, do not seem to be correct.

We conclude that life without work, especially in the sense of being unemployed, and probably also in the sense of being incapacitated, may lead to reduced health as well. Nevertheless there is no scientific evidence for this, in spite of the fact that research on a high aggregate level has resulted in correlations between unemployment and health. Conclusions based on these correlations are subject to methodological criticism. Another reason for doubts about the conclusions lies in the concepts of health used in varies studies. These vary considerably: phystcal health, mental health, social functioning, role functioning, well-being, mortality and morbidity, life expectation, and behaviour that might lead to 111 health (smoking, drug and alcohol-abuse). Operationalizations of each of these concepts differ as we11.

In order to avold results that are open to criticism, several economists and social scientists have suggested dolng micro-level studies wh a transwersal and longitudinal approach and restricting the concepts of health to diseases, 11lness and 111ness behaviour. In our research we have followed these suggestions.

In chapter four, the research questions that we set out to answer, are formulated. Hypotheses and operationalizations are given as we11. The questions were as follows:

1 Do men who are incapacitated for work, who are unemployed or early retired differ from each other and from working men in reported health, locus of control, habits which endanger health and social particlpation? 
2 Does duration of non working influence health, locus of control, unhealthy habits and socdal participation, and if so, in what way? Because the rellablilty of health reports by those incapacitated for work or unemployed has been questloned, we have paid attention to this issue as well. Some sclentists argue that people belonging to the first category are inclined to report poorer health than they actually experience, while those belonging to the second are inclined to report better health than they experience. They are thought do so to legitimate their position of non-employability. These suppositions have led to a third research-question: Does the reported health-status of Incapacitated, unemployed and early retired men differ from the actual state of health as abstracted by general practitioners from their medical files.

On the basis of the 1iterature referred to in chapter two, as well as in chapter four, hypotheses were formulated.

State of health was measured using criteria such as presence of chronic diseases or handicaps (disease), number of visits to the doctor (medical consumption), reported health in general terms, worrying about health, physical complaints (illness), and self-medication such as use of tranquilizers (illness behaviour). State of health, as measured by doctors, was classified in terms of the International Classification of Primary Care (ICPC).

Health locus of control was subdiulded into three dimensions: internal orlentation, external orientacion (doctors) and chance orientation. Moreover we have measured the relative weight the interviewees attached to their health.

Unhealthy habits were measured in terms of the percentage of smokers and the numbers of clgarettes consumed, the frequency and quantities of alcohol consumption, and the frequency of bodily excercise. Moreover interviewees have been asked for their opinion about their way of life in terms of healthy/unhealthy.

Social particlpation was subdivided into: 
- number of contacts with friends "relatives and (ex)colleagues;

- membership of clubs and number of hours spent on this per week;

- voting behaviour (in political elections);

- membership of religious organisations/sects.

Chapter five deals with the research methods, populations and statistical methods used. This dissertation is based on two studies.

The first concerns a large nationwide panel-survey ( 1981 and 1983 ) among working and non-working men.

The number of non-working participants in the panel-survey consisted of 49 unemployed in 1981 and 89 in 1983, 179 incapacitated for work in 1981 and 155 in 1983 , 46 early retired in 1981 and 49 in 1983.

The second study involved research in general practice: with the aid of medical files, flve general practitioners belonging to the same health center drew up problemilsts of working, incapacitated, unemployment and early retired men. This information enabled us to compare reported health with health as assessed by health care professionals. Non-working particlpant in this "GPstudy" included 63 unemployed men, 170 men incapacitated for work and 32 early retired men.

Results of the panel are based partly on analysis of variance (ANOVA) and partly on precision matching. These methods enabled us to control differences between categories in marital status, age, social status and, if necessary, duration of non-employability.

other (statistical) methods we used included the Mann-Whitney-UWilcoxon-Rank Sum W Test and the H1coxon Matched PaIrs Signed Rank Sum $W$ Test.

The results of the two studies are summarized below.

Health.

Those incapacitated for work showed high relative and absolute scores on nearly all varlables used, compared to unemployed, early retired and working participants. Unemployed workers did not differ from the working population in these respects. The same applies to the early retired, who had even lower scores for physlcal complatints. These results, which date from 1983, largely confirmed the proflle found in 1981. 
When consldered health as reported by doctors we found the same profile. This means that the so-called subjective judgement on health did not differ from the so-called objective judgements made by doctors, in spite of the fact that reported health was measured in a different way from health as stated by doctors.

cluster analysis made clear that within the category of men incapacitated for work $17 \%$ reported good health. These might possibly be 'concealed umemplayed", although we must be careful in applying this label to them. Their good health might also be conditional, in the sense that absence of work(pressure) might have led to this state of heaith.

Although good health is not synonymous with concealed unemployment government's estimation of $50 \%$ unemployed among the incapacitated seems to be far from realistic.

of the umemployed, $27 \%$ reported poor health; if the $17 \%$ mentioned above belong to the 'concealed unemployed', these $27 \%$ might belong to the category of 'concealed incapacitated'. Nevertheless, we found that nearly the same percentage of workers $(28 \%)$ were in poor health as we11.

Among the retired $38 \%$ were in a poor state of health, which is not amazing, since all of them were between 57 and 65 years old.

\section{Locus of control.}

The three categories of non-workers did not differ in their chance orientation. The unemployed did not differ from the other two categories in their internal orientation, but the incapacitated showed a lower internal orientation than the early retired. This means that, compared to the early retired, the incapacitated have less falth in their ability to influence their own health. As far as external orlentation is concerned, the incapacitated showed more faith in doctor' abilities to influence their health than the unemployed. The early retired did not differ form the other two categories in this respect. All three categorles attached the same weight to health as such. Workers differed from the incapacttated in their internal orientation (higher) and in their external orlentation (lower). Workers showed less external orientation than the early retired; moreover they 
attached less weight to health as such. Workers and unemployed did not differ form each other.

Unhealthy habits

Contrary to our hypothesis, the incapacitated were found to have more unhealthy habits than the unemployed and the early retired. Because of their bad health we expected fewer such habits.

The unemployed and early retired scarcely differed from workers in this respect. The incapacitated differed from workers in nearly the same way as they differed from the other two categories of non-workers. Among the incapacitated we found a lower percentage of drinkers than among the workers.

The incapacitated differed from the unemployed and the early retired in their opinions about their way of life in terms of healthy / unhealthy; they perceive their way of $11 f$ as less healthy. The workers and the incapacitated did not differ from each other in this respect. The unemployed and the early retired however percelved their way of life as more healthy than workers do.

\section{Social participation}

The three categories of non-workers hardly differed in social participation. Nevertheless we found that the unemployed were less often members of religious organisations. The unemployed spent more hours in clubs than the early retired, but did not differ from the uncapacitated in this respect. The early retired hardly differed from the workers, while the unemployed differed slightly from them and the incapacltated differed greatiy.

Among the incapacitated and among the unemployed we found a lower percentage of members of clubs, as well as a lower percentage of people voting in political elections, as compared to workers.

All three categories of non-workers did not differ in the percentage of membership of religlous organisations. However, the incapacitated have more frequent contacts wh friends, acquaintances and relatives than workers; moreover, they spend more hours in clubs. 
Duration of non-employability

In this study the phrase 'long term non-employment' is taken to mean 21 years or longer whout paid work; the phrase "short term unemployment' is taken to mean less than 2 years without paid work.

The longitudinal approach meant that we followed non-workers for two years. In order to be sure that any differences between the 1981 and 1983 situations could be attributed to 11 fe without work, we developed a prectsion-matching procedure, resulting in a matching of 55 incapacitated men with 55 comparable working men, a matching of 17 unemployed men with 17 comparable working men and a matching af 8 early retired men with 8 comparable working men. This last group was so small that we decided not to include it in our results.

Matching was based on age, social class, marital status, urbanization and region.

Long and short teru early retired did not differ in reported health. Long term unemployed and incapacitated men showed a slightly poorer state of health than the short-term non-workers.

From a longltudinal point of view, the health of the Incapacitated and unemployed did not change. However, among the incapacitated more than $8 \%$ ( 15 men) of the 1981 population died before 1983 ; among the unemployed this precentage was 'only" $2 \%$ ( 1 man). Therefore we concluded that long term non-employability among the incapacitated leads to poor health.

Since this was not the case among the unemployed, we suppose that the cause of the poorer health status of the incapacitated was initial poor health, rather than life without work. We did not measure state of health and other aspects of the early retired in a longitudinal manner, because the numbers were too small (8); nevertheless the percentage of men not interviewed in 1983 because of reported sickness was higher ( $11 \%$ ) than that mong the Incapacitated (5\%) and the unemployed $(0 \%)$. We do not know whether this high percentage was caused by IIfe without work. However, we do not consider it likely, as most of them probably stopped working voluntarily.

Locus of control was only measured in a transversal manner, since questions on this topic were not used in 1981. The only difference we 
found was that the long term incapacitated were less chance orlented than the short term incapacitated. As far as the relative weight given to health was concerned, we found no differences between 1981 and 1983.

Among the long term incapacitated and unemployed we found one point of difference in unhealthy habits compared to short term incapacitated and unemployed. Both long term categories included a higher percentage of smokers. In the longitudinal study we only found a relative increase in the percentage of smokers among the incapacitated.

This means that the transversal difference found among the unemployed is probably due to a selection effect and not to the duration of non-employability.

As for the particlpants' views on thelr own lives, we only found differences among the unemployed. The long term umemployed perceived their way of life as less healthy than the short term unemployed. Moreover duration of unemployment led to a perception of the participants way of Iife as less healthy. This probably means that the transversal aifference found is not a selection effect, but merely an effect caused by being unemployed.

Transversally, we compared the long and short term non-workers with regard to all variables of participation mentioned above.

Longitudinally, we used only two valables, v1z. voting behaviour and nembership of religious organisations. The other variables could not be compared for 1981 and 1983. In the transversal study we found no differences among the incapacitated. Longltudinally, we found only one relative change: a decrease in the percentage that reported to be a member of a religlous organisation. Among the unemployed we found one difference in the transversal approach: among the long term unemployed there appeared to be a lawer percentage of voters than under the short term unemployed. In the longitudinal study we did not find any differences in this respect. This means there is probably only a selection effect. Nevertheless a causal effect of unemployment on voting behaviour cannot be excluded: among the unemployed we saw a non-significant decrease, whlle among the employed we saw a not slgnificant increase in the percentage of voters between 1981 and 1983 . 

Literatuur

Bijlagen

Dankwoord

Curriculum Vitae 



\section{Literatuur}

- Adriaanse H, Drop MJ, Halfens $R$, Philipsen $H$. Leeft Nederland Oké? Verslag van een onderzoek naar de beleving, opvattingen en gedragingen inzake gezondheid. Maastricht: Rijksuniversiteit Limburg, 1981.

- Banks MH, Jackson PR. Unemployment and risk of minor psychiatric disorder in young people: cross sectional and longitudinal evidence. Psychol Med 1982; 12: 789-98.

- Bartley M. Unemployment and health: selection or causation - a false antithesis. Med Sociol News 1985; 11: 8-9.

- Becker JW, Vink R. Werklozen, arbeidsongeschikten en werkenden vergeleken. Den Haag: Soclaal en Cultureel Planbureau, Stukwerk 18, 1984.

- Beerling RF. Filosofie en arbeld. In: Arbeid en Samenleving. Rotterdam: Untversitaire pers, 1964.

- Bos GAM van den, Maas PJ van der, Habbema JDF. Rapport "Zorgbehoeften en zorggebruik bij chronisch zieken". Amsterdam/Rotterdam: Instituut Sociale Geneeskunde, Universiteit van Amsterdam en Instituut Matschappelijke Gezondheidszorg, Erasmus Universitelt Rotterdam, 1986. Rapport.

- Bosch FAJ van den, Petersen C. Arbeldsmarkt en arbeidsongeschiktheid. Econom Stat Ber, 1979: 580-6.

- Bosch FAJ van den, Petersen C. De omvang van de verborgen werkloosheld in de WAO. Econom Stat Ber, 1980: 52-8.

- Bramlage CAA. Gezondheld en Zlekte te Zutphen. Een enquete naar de gezondheldszorg bij 536 gezinnen. Assen: van Gorcum, 1962.

- Brenner MH. Industrialization and economic growth. Estimates of their effects on the health of populations. In: Brenner MH, Mooney A, Nagy TG (eds). Assesining the contributions of the soclal sciences to health. Washington: American Academy for the advancement of sclence, 1980 . 
- Brenner MH. Economic change and mortality by cause in selected European countries: special reference to behaviour health risks, emphasising alcohol consumption. In: Svensson PG, Zöliner H (eds). Health policy implications of unemployment. Copenhagen: WHO, 1985: 143-81.

- Bremer MH. Economic changes and heart disease mortality. Am Public Health 1971; 61: 606-11.

- Brenner MH. Health costs and benefits of economic policy. Inter Health Serv 1977; 1: $581-623$.

- Brenner MH. Mortality and the national economy: A review, and the experience of England and Wales. Lancet 1979; 11: 568-73.

- Broadhead W, Kaplan B, Sherman A, Wagner E, Schoenbach $V$, Grimson R, Heyden $S$, Tibblus $G$. The epidemiological evidence for a relationship between social support and health. Am J Epldemiol 1982; 521-37.

- Buys PC. Curatieve gezondheidszorg, ziekteverzuin en arbeidsongeschiktheid. Rotterdam, 1984. Proefschrift.

- CBS, Statistieken, Den Haag.

- Crawford A, Plant MA, Kruitman N, Latcham R. Unemployment and drinking behavior: some data from a general population survey of alcohol. BI J Addict 1987; $82: 1007-16$.

- Currer C, Stacey M (eds). Concepts of health, illness and disease. Lemington, Hamburg, New York: Berg, 1986.

- Dupults FMHM, Hasman A, Heumakers TAJ, Schoonbrood GGM. Beschrijving Hulsartsonderzoek Systeem (HOS). Tijdschr Med Informat 1986; 15: $25-9$.

- Dupuits FMHM, Hasman A, Heumakers TAJ, Schoonbrood GGM. HTOS en huisartsinformatle en onderzoekssysteem. Medisch Informatica Congres (MIC), proceedings, 1987; 154-60.

- Dupults FMMM, Hasman A, Heumakers TAJ. Het huisartsinformatie en onderzoekssysteem (HIOS). Tifdschr SOC Gezondheidszorg 1986; $23:$ $733-4$.

- Durinck JR, K1Jlstra-ten Thije AM. Eerder ophouden met werken; invloeden op de gezondheld. Elndhoven: Philips Bedrijfsgezondheid, 1986, Intern rapport.

- Eyer J. Prosperity as a cause of death. Int J Health Serv 1977; 7: $125-50$. 
- Fagin L, Little M. The forsaken families: a timely and disturbing report on the effects of unemployment on famly life in Britain. Harmondsworth: Penguin Books, 1984.

- Forbes JT, McGregor A. Unemployment and mortality in post-war Scotland. I Health Econ 1984; $3: 239-57$.

- Fryer D. Monmouthshire and Marienthal: Sociographics on two unemployed communities. In: Unemployed people. Fryer D, U1lah P (eds). Philadelphia: Open University Press, 1987.

- Gemeenschappelijke Medische Dienst. WAO-toetreders uit 1985. Een beschrijving GMD cahier nr. 12, november 1987. Amsterdam.

- Gore S. The effect of sacial support in moderating the health consequences of unemployment. J Health Soc Behaw 1978; 19: 157-65.

- Gravelle HSE. Time Series Analysis of Mortality and Unemployment: editorlal. J health Econ 1984; 3: 297-305.

- Gravelle HSE. Does unemployment kill? Nuffield/York portfolios. Nuffield Provincial Hospltal Trust. Oxfordshire: Burgers \& Son (Ablingdon) Ltd, 1985; 9: 1-8.

- Gravelle HSE, Hutchinson G, Stern J. Mortality and unemployment: a critique of Brenner's time series analysis. Lancet 1981; 11: 675-9.

- Groothoff JW. Epidemialogie van de arbeldsongeschiktheid. Tijdschr Soc Geneeskd 1980; 58 (suppl); 80-3.

- Groothoff JW. Gezondheldstoestand van de beroepsbevolking. Groningen, 1986. Proefschrift.

- Groothoff JW. Gezondheldszorg en 3-maands verzuimgevalien. Tijdschr Soc Geneeskd 1981; $59: 42-9$.

- Hagenaars AJM. The perception of poverty. Leiden, 1985. Proefschrift

- Halfens RJG, Drop MJ, Philipsen H. Leefwijze en subjectieve gezondheid wan een panel ult de Nederlandse bevolk1ng. Maastricht: Rijksuniversiteit Limburg, 1984.

- Halfens RJG. Locus of control. Beheersingsorientatie in relatie tot zlekte en gezondheidszorg. Mastricht, 1985. Proefschrift.

- Halfens R, VHsser A Ph, Adriaanse H. De beheersingsorlëntate met betrekking tot gezondheids- en zlektegedrag. In Press.

- Hermans D, Sas C, Schraven B. Schat de regering de arbeldsongeschiktheidsschatting juist in? Sociaal Maandblad Arbeid, februar 1986: 127-36. 
- Hoofddrectie Personeelszaken PTT. Experiment flexibel uittreden van PTT personee1. Den Haag* 1980. Rapport.

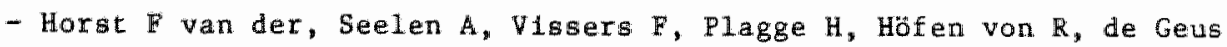
C. Kleijnen J. Reglstratie in de hulsartspraktijk: over de betrow baarheid, practische hanteerbaarheid en adequatheid van het $R F E$ classificatiesysteem. Hulsarts wet $1985 ; 28: 229-34$.

- Horst $F$ van der, Bartholomeus P, Berkhout J, Zuidweg J. Diabetesspreekuur in de eerste $11 j n$ : knelpunten en aanbevelingen. In: Beugen $M$ van, Boerma WGW, Cate RS ten et al. Eerstelijnszorg. Alphen aan de Rijn: Samson Stafleu, 1985: 127-38. Losbladig.

- Hunfeld A. Werkloosheid, WAO en ABP. In: Wrooland V Chr. Wao en werkgelegenhe1d. Amsterdam: Stichting CCOZ, 1980.

- Huygen FJA. Preventie en somatische fixatie. Huisarts Wet. 1978; 21 : $363-65$.

- Janssen HJ, Kools JHGM. Experiment flexibel uittreden bif PTI: kenmerken en motieven van deelnemers en niet-deelnemers. Den Haag: PTT centrale afdeling sociaal wetenschappelijk onderzoek, 1981 . Rapport.

- Jackson PR, Warr PB. Unemployment and psychological 111 health: the moderating role of duration and age. Psychol Med; 14: 605-614.

- Joosten J, Drop MJ. De betrouwbaarheld en vergelijkbaarheid van drie versies van de VOEG. Gezondh Samenl 1987; 4: 251-65.

- Kagenaar DB, Stolk AP, Timer LM (red.). Huisarts en arbeidsongeschiktheid: inleiding. Alphen aan de Rijn: Samson Stafleu, 1985.

- Kaplan A, Camacho T. Percelved health and mortality: a nine-year follow-up of the human population laboratory cohort. Am I Epid 1983; $117: 292-304$.

- Kesteloo A. Bedrijfsgeneeskundige aspecten van een bedrijfssluiting I en II. Tijdschr Soc Geneeskd 1975; 53: 472-7; 516-20.

- Klein Teeselink H, Sonnemans $W$. Bouwstenen voor diabeten thuiszorg. Eindverslag van het diabetes thuiszorgproject bij de Provinciale Groninger Vereniging "Het Groene Kruis". Wageningen: Landbouwhogeschool Wageningen, 1985. Doctoraalscriptie.

- Knlbbe R. Van gangbaar tot problematisch drankgebrulk. Maastricht, 1984. Proefschrift.

- Knottnerus JA. Het arbeidsongeschiktheidsprobleem in de huisartspraktijk. In: Kagenaar DB, Stolk AP, Timmer LM (red.), Huisarts en arbeidsongeschiktheid. Alphen aan de Rijn: Samson Stafleu, 1985. 
- Krause N, Strijker S. Stress and we1l-being: the buffering role of locus of control beliefs. Soc Sc Med 1984;18:783-90.

- Kruidenier HJ, Bakker TPV. De Invloed van het personeelsverloop op de ontwikkeling van het zlekteverzuim. Tijdschr Soc Gezondheidsz $1985 ; 63: 302-8$.

- Lamberts H, Wood $\mathrm{M}$ (eds..). ICPC International Classification of Primary Care Oxford. Oxford: University Press, 1987.

- Lange de J, Senhorst G. Als je man de hele dag thuis is. Een onderzoek naar ervaringen en perspectieven van vrouwen van werklozen en WAO'ers. Nijmegen: Katholieke Universiteit Nijmegen, 1985. Doctoraliscriptie.

- Levi L, Brenner 5o. Vulnerability among long term unemployed; a longitudinal study of mental and physical health among Swedish women at different stages of unemployment. Ljubljana, 1985. Paper.

- Luttik R. De werkloosheidsomvang op basis van de registratie van de arbeidsbureau's en volgens de arbeidskrachtentelling van het CBS. ETI bulletin 1987; 12:11-4.

- Luyckx RTH. De lotgevallen van de langverzulmer. Groningen, 1982. Proefschrift.

- Maassen GM, Goede MPM de. Hoe zien andere mensen werklozen en hoe zien werklozen zlchzelf: resultaten van tien jaar onderzoek over de publieke opinie. In: Spruit I, Tazelaar F (red). Leven met werkloosheid. Groningen: Wolters, 1987.

- McAvinchy ID. Unemployment and mortality: some aspects of the Scottish case 1950-1978. Scote J Polit Econ 1984; 31: 827-53.

- Meems A. Een onderzoek naar de effecten van een dreigende bedrijfssluiting (70 recidivi en 70 primi). Tijdschr Soc Geneeskd 1981; 59: $565-71$.

- Merens-Riedstra HW. Leven zonder werk: een soclaal-wetenschappelijk onderzoek naar arbeidsongeschiktheid. Mastricht, 198l. Proefschrift.

- Metsemakers JFM, Plagge HWM. De probleem11jst. Registratienet Hulsartspraktijken Rijksuniversiteit Limburg, 1987. Rapport.

- Meyer JS, Brouwer H, Lamberts H. De ICPC als diagnostische classiflicatie I: nog meex kewze voor de hulsarts? Hulsarts Wet 1987; 30 : $13-9$. 
- Minfsterie van Soclale Zaken. vut, verwroegde uittreding in ontwikkeling. Den Haag: 1981. Rapport.

- Nifhul F, Kalpachild F. Werkloosheid, dreigende werkloosheid en gezondheld: een literatuuronderzoek. Maastricht: Rijksuniversiteit Limburg; 1982. Rapport.

- Nithuls F, Soeters J. Zliekteverzuim, arbeidsongeschiktheld en de organlsatie van de arbeid. Tijdschr Soc Geneeskd 1983; 19:686-93.

- Nijhuls Fullinga R. ReIntegratiebeleid in organisaties. Tijdschr Soc Geneeskd 1987; 65;816-12.

- ormel. H. Moelte met leven of een moeilljk leven? Groningen: Konstape1, 1980.

- Prag BMS van, Emanuel H. On the concept of non-empioyability with respect to a non-homogeneous labourforce. Leiden: 1981. Rapport COEP.

- Phllipsen H. Afwezlgheid wegens ziekte. Groningen: Wolters Noordhoff, 1969.

- Rapportage Arbeidsmarkt. Ministerie van Sociale zakeri en Werkgelegenhe1d. Den Haag: 1982-1987.

- Research en Marketing. Verantwoordingsrapport inzake het onderzoek "Gezondheid: een panelonderzoek naar de beleving, de opvattingen en de leefwijze inzake gezondheid", ten behoeve van de Rijksuniversiteit Limburg, Heerlen: Research en Marketing, 1983. Rapport.

- Reek J van, Diederiks J, Philipsen H, Zutphen W van, Seelen $T$. Subjective complaints and blood pressure. J Psychosom Res 1982; 26: $155-65$.

- Reek van J. Brleven: De invloed van kosten, vrouwenemancipatie en anti-rookinformatie op veranderingen in het rookgedrag. Tijdschr Alcohol Drugs, 1984; $1: 41-3$.

- Sandlow Lu, Bashook PG. Problem oriented medical records: self instruction for practitioners. Chicago: Michael Reese Hospital in Medical Center, 1978.

- Schepers Th. Werkloos .... en wat dan? Scheveningen: Stichting. Maatschappij en Oaderneming, 1980 .

- Schuttemaker R. Vroegrijp voor de WW: jeugdwerkloosheid, inzicht en ultweg. Deventer: Kluwer, 1981 .

- Segers JHG, Hagenaars JAD. Sociologische onderzoeksmethoden deel IX. Technieken van causale analyse. Assen: Van Gorcum, 1980. 
- Smulders FGW, Leeuwen P van, Nooten WN van. Werkloosheid en ziekteverzuim: theorie en longitudinaal onderzoek. Gezondh Samenl 1983; 4: $23-32$.

- Sociaal en Cultureel Planbureau (SCP). Enige aspecten van arbeid in de toekomst: saciale en culturele studies. 7. "s Gravenhage: staatsuttgeverij, 1986 .

- Soeters J. Patiënt, gezondheidszorg en langdurige ziekte. Maastricht, 1983. Proefschrift (stelling).

- Smart RG. Drinking problems among employed, unemployed and shift workers. J Occ Med 1979; 11: 731-36.

- Soclaal en Cultureel Rapport 1978. Sociaal Cultureel Planbureau. Den Ha.ag: 1978 .

- Sprengers M, Tazelaar F. Werkloosheid en sociaal netwerk. In: I. Spruit en F. Tazelaar (red). Leven met werkloosheid. Groningen, Wolters-Noordhoff, 1987.

- Spruit IP. Unemployment, employment and health. Leiden: 1983. Proefschrift.

- Spruit I. Definities van werkloosheid en analyseproblemen. Sociol Gids $1984 ; 31: 25-31$.

- Spruit IP, Verkley $H$, de Jong-Gierveld J, Steverink E. Eenzaameid. en de rol van ondersteunende kontakten en zorgen bij werkloosheid. In: Spruit I, Tazelaar F (reds). Lewen met werkloosheid. Groningen: Wolters Noordhoff, 1987.

- Svensson PG, Zöllner H. Introduction. In: WHO. Health policy implication of unemployment. Copenhagen: WHO, 1985: 1-7.

- Tazelaar F, Sprengers M. Werkloosheid en soclaal dsolement. Soclol Gids $1984 ; 31: 48-80$.

- Ullah P, Banks M, Warr P. Soclal support, social pressure and psychological distress during unemployment. Psychol Med 1985; 15 : 283-9.5.

- Verkley H, Sprult IP, Bastiaansen JPAM, Nieuwenhuljzen MG van. Gezondheldsklachten en hulpvragen van werklozen. Med Contact 1984; $45: 1441-4$.

- Verkley H, Sprult IP. Werkloosheid en gezondheld: een wederkerfge relatie. In: Sprult IP, Tazelaar F. (reds). Leven met werkloosheid. Gronlngen: Wolters Noordhof, 1987: 65-83. 
- Visbers AMC, ter Huurne AO. De zin van het arbeidsethos. Waardenveranderlng en/of culturcris1s, 1984 . Congrespaper.

- Vroege D. Verkenningen rond het koncept belasting-belastbaarheid. Tijdschr Soc Geneeskd 1982; $24 ; 793-8$.

- Warr PB. Psychological aspects of the employment and unemployment. Peychol Med 1982; 12:7-11.

- Warr PB. A national study of non-financial employment commitment. J Decup Psychol 1982; 55; 297-312.

- Warr PB, Payne RL. Soctal class and reported changes in behavior after job 10ss. MRC/SSRC SAPU 1982; memo 535.

- Warr PB. Werk en werkloosheid. Handboek arbeids- en organisatiemaatschapp1j. Deventer: Van Loghum Slaterus 1983; 9; 213-31. Lo6bladig.

- Warr PB. The psychological fmpact of continuing umemployment: some longltudinal data on a general model. Ljub1jana: who, oktober 1985. Congress paper.

- Weeda HWh. Herstel van revalidatie na hartinfarct. Ned Tijdschr Geneeskd 1984: 868-9.

- Westcott G. The effect of unemployment on the health of workers in a UK steel town: preliminary results. In: WHO, Health policy implicatIons of unemployment. Copenhagen: WHO, 1985; 261-73.

- Wetenschappelijke Raad voor het Regeringsbeleid. In: Ministerie van CRM. Actieven en nlet-actieven, 1979. Rapport.

- Wiersma D. Psychasociale stress en langdurige arbeidsongeschiktheid. Gronlngen: Konstape1, 1980.

- Weze1 JAM van. Beleving van werkloosheid. Gedrag 1975; 2: 63-79.

- WHo, Unemployment and heaith. New approaches in research and action. Copenhagen: WHO, 1983.

- Zee $J$ van der. De vraag naar diensten van de huisarts. Maastricht, 1982. Proefschrift. 


\section{Bijlagen}

Tabel l Vergelijking verdeling werkloze, arbeidsongeschikte en verwroegd gepensioneerde mannen 1981 en 1983 naar landsdeel* (\%).

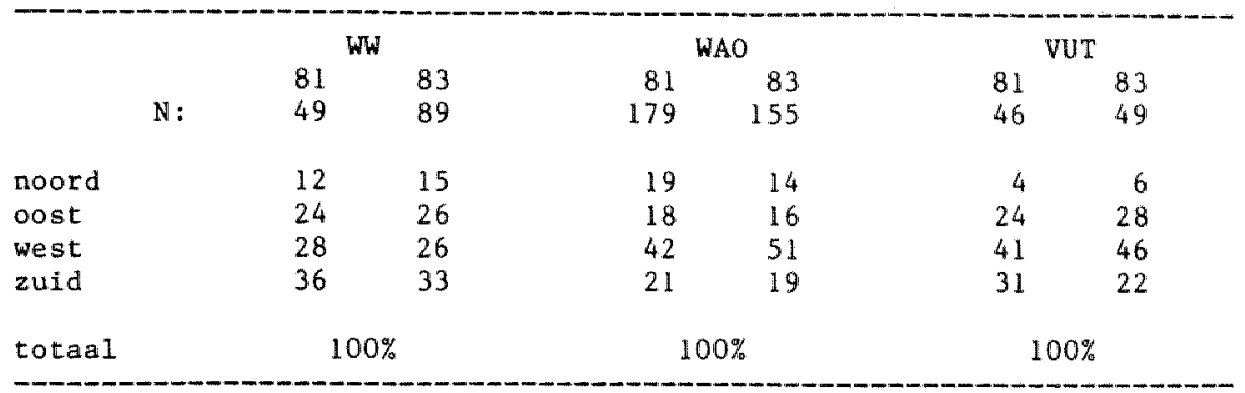

* noord omvat Groningen, Friesland en Drente oost omvat Gelderland en Overijssel

west omvat Noord- en Zuid-Holland, Utrecht en Zeeland

zuid omvat Noord-Brabant en Limburg

Tabel 2 Vergelijking verdeling werkloze, arbeidsongeschikte en vervroegd gepensioneerde mannen in 1981 en 1983 naar urbanisatiegraad $(\%)$

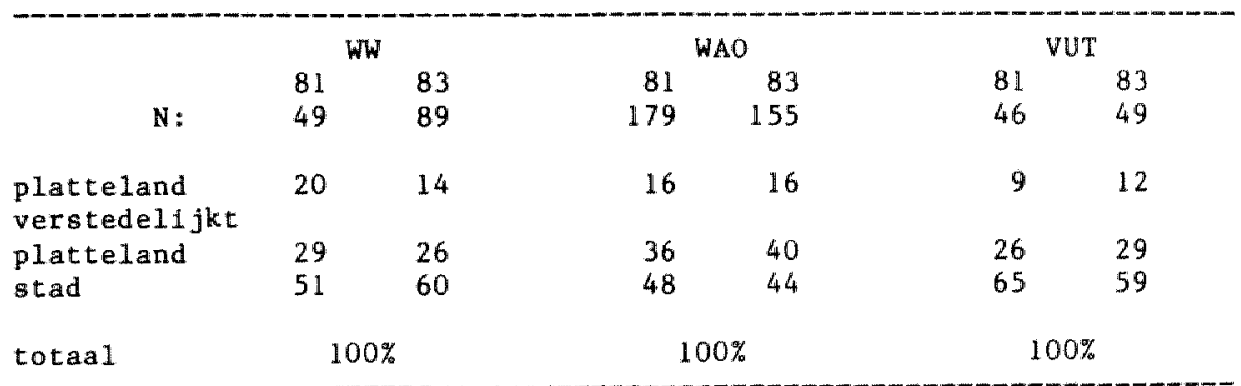


Tabel 3 Vergelljking verdeling werkloze, arbeidsongeschikte en vervroegd gepensioneerde mannen in $81 / 83$ op basis van 1981 naar burgerlijke stat $(\%)$.

$\begin{array}{lrrr} & \text { Wh } & \text { WAO } & \text { VUT } \\ & 21 & 91 & 27 \\ \text { gehuwd } & 71 & 89 & 81 \\ \text { samenwonend } & 5 & 1 & 4 \\ \text { ongehuwd/ngg } & 19 & 2 & 4 \\ \text { gescheiden } & 5 & 7 & 4 \\ \text { weduwhaar } & - & 1 & 100 \% \\ \text { total } & 100 \% & 100 \% & \end{array}$

Tabel 4 Vergelijking verdeling werkloze, arbeldsongeschikte en vervroegd gepensioneerde mannen in $81 / 83$ op basis van 1981 naar sociaal-economische klasse (\%).

$\begin{array}{lrrr} & \text { N: } & \text { WAO } & \text { VUT } \\ & 21 & 91 & 27 \\ \text { hoog } & & 10 & 33 \\ \text { midden } & 14 & 19 & 30 \\ \text { laag } & 86 & 71 & 37 \\ \text { total } & 100 \% & 100 \% & 100 \%\end{array}$


Tabel 5 Vergelijking verdeling werkloze, arbeidsongeschikte en vervroegd gepensioneerde manmen in $81 / 83$ op basis van 1981 naar landsdee $1(\%)$.

\begin{tabular}{lrrr} 
& WW & WAO & VUT \\
& 21 & 91 & 27 \\
noord & 10 & 14 & - \\
oost & 19 & 12 & 30 \\
west & 29 & 54 & 30 \\
zuld & 42 & 20 & 40 \\
total & $100 \%$ & $100 \%$ & $100 \%$ \\
\hline
\end{tabular}

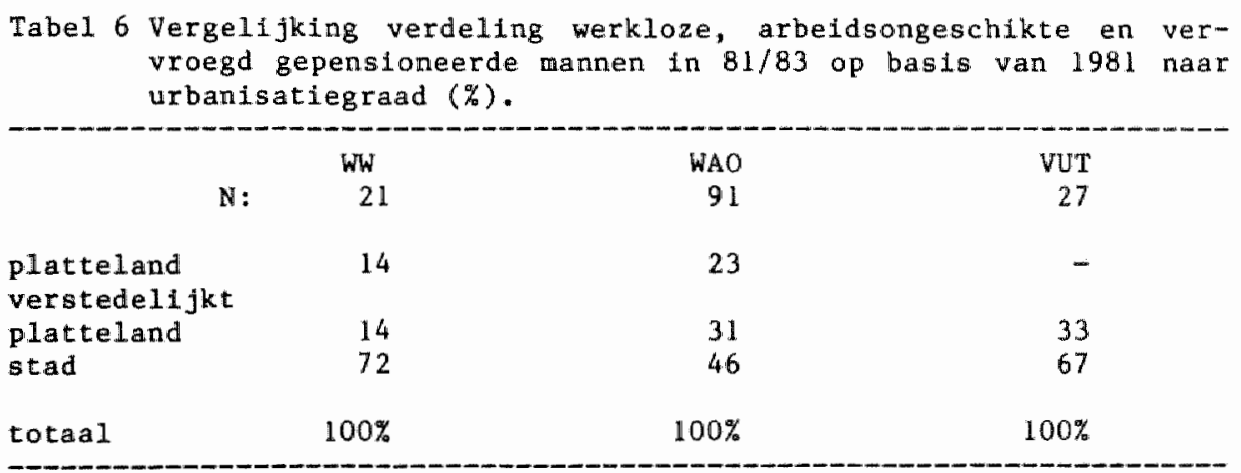




\section{III}

- Totstandkoming populatle in de huisartspraktijk.

De doe1groep bestaat uit mannen van 21 tot 65 jaar, met de Nederlandse nationalitelt en niet wonend in Instellingen; 65 jarigen zijn hierbij uitgesloten. Gegeven deze omschrijuing vielen in eerste instantie 2631 patienten onder de potentièle onderzoekspopulatie, zoals uit het valgende overzicht naar voren komt. Buitenlanders en instellingsbewoners waren zoveel mogelijk uitgesloten. Zoals we later in deze tekst zien, werden toch nog buitenlanders en instellingsbewoners ontdekt. Het verschil in het aantal mannen binnen de leeftijdscategorie van 21-64 jaar in de vorige tabel (3056) en deze tabel (2631) kan in eerste instantie toegeschreven worden aan buitenlanders en insteliingsbewoners.

- vastgestelde totale aantal mannelijke patiënten 21-64 jaar 2631

- buitenlandse mannelijke patiënten $\quad-60$

- verstuurde vragenlijsten $\quad 2571 \quad 100 \%$ bruto response $\quad-1620 \quad 63 \%$

$\begin{array}{lll}\text { bruto non response } & 951 & 37 \%\end{array}$

Uit dit overzicht blijkt dat 60 mannelifke patiënten in tweede instantie geidentficeerd zijn als butenlanders en derhalve alsnog bulten de onderzoekspopulatie vallen. De totale response bedroeg 1620 (63\%). Binnen twee weken na het versturen van de vragenlijsten waren 1115 formulieren 1ngevuld terug ontvangen. Na een herinnering volgden nog eens 505 enquêteformulieren. Het vermelde percentage (63\%) kan rede$11 \mathrm{jk}$ genoemd worden. Niettemin hadden we een hoger percentage verwacht (circa $80 \%$ ), omdat de vragenlijst verstuurd was met een begeleidende brief die mede ondertekend was door de hulsartsen. 
Screening van de ingevulde formulieren makte duldelifk dat 197 personen $(12,2 \%)$ toch nog buiten de doelgroep vielen. De verantwoording ervan is als volgt:

- ingevulde formulieren:

- instellingsbewoners $\quad 74$

- vrouwen 56

- buitenlanders 18

- niet door geadresseerde persoon ingevuld 4

- 65 jaar of ouder 8

- niet ingevulde formulieren:

- uit praktijk ten gevolge van verhuizing

- uit praktijk vertrokken om andere redenen

- overleden

Dit brengt ons op de volgende correctie op de response:
- ongecorrigeerde response
1620
$100 \%$
- response bulten gedefi- nieerde insluitingscriteria onderzoekspopulatie
- gecorrigeerde response

Resteert nog de bespreking van de weigeringen. In totaal waren er 15 weigeringen, op basis van de volgende gronden:

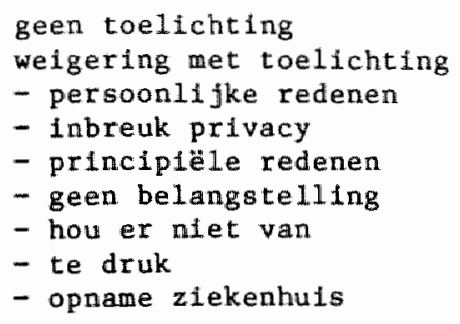

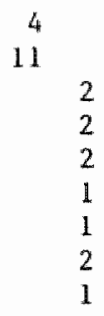

15

Het percentage van de netto response weigeringen 1 s derhalve $1 \%$ ( $15 /$ 1423 . $100 \%$, hetgeen een lag getal 1 . 
Per saldo is de vaststelling van het gecorigeerde nettoresponse percentage als wolgt berekend.

We platsen in de teller de gecorrigeerde response, verminderd met de welgerlngen; in de noemer komt: het aantal verstuurde vragenlijsten min de response die buiten de gedefinieerde onderzoeksgroep valt, verminderd wet het veronderstelde gedeelte van de bruto non-response dat bulten de onderzoeksgroep valt. Het geschatte gedeelte berust op de eerder vermelde response buiten de gedefinjeerde onderzoekspopulatie. In cijfers uftgedrukt:

$\left(257 \overline{1}-1 \frac{1}{9} \frac{423}{7}\right)-\left(12 \frac{1}{12}, \overline{2} \% \times 951\right)=\frac{1408}{2158}=65,3 \%$ 
Uit de op de volgende pagina vermelde tabel komt naar voren dat een aantal der werklozen en arbeldsongeschikten een volledige, dan wel een deelt1jdbaan heeft. Het aandeel werklozen dat een deeltijdbaan heeft is aanzienlifk: 16 van de $81(20 \%)$. Eveneens valt op dat het merendeel der partieel arbeidsongeschikten (68\%: 21 van de 31) rapporteert een baan te hebben. Van alle volledig arbeldsongeschikten rapporteert een klein gedeelte ( $5 \%: 9$ van de 170) een baan te hebben. Onder de vervroegd gepensioneerden is het opwallend dat $19 \%$ ( 8 van de 42 ) vermeldt betald werk te verrichten.

omdat in de panelstudie een vergelijking gemaakt is van niet werkende arbeidsongeschikten, werklozen en vervroegd gepensioneerden met werkenden, hebben we degenen die tot deze categorieën behoren en toch (deel)arbeid verrichten niet in de analyse betrokken. 


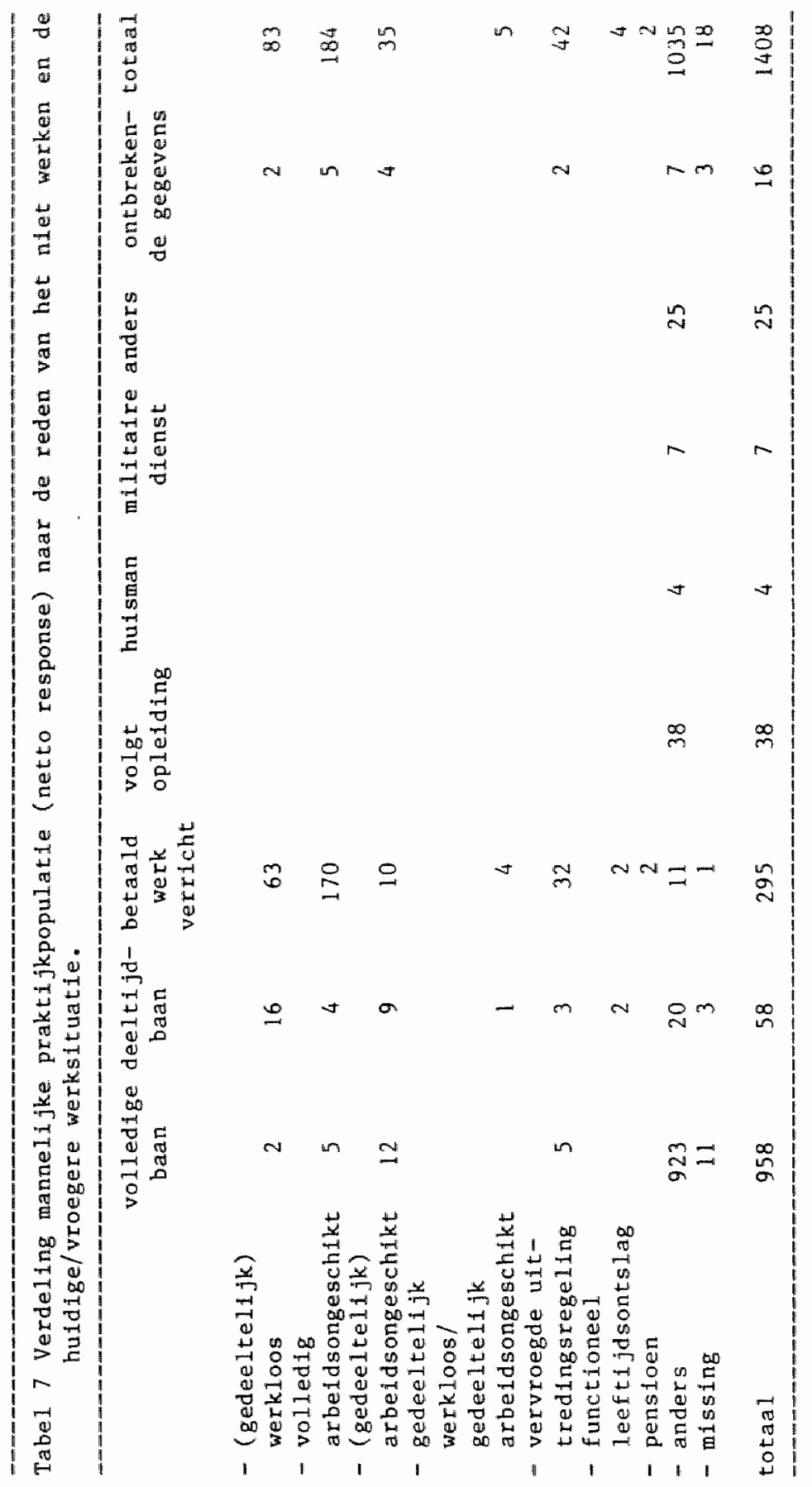




\section{Dankwoord}

Vanaf het moment dat het onderzoek "Gezondheld en niet werken", drie Jaar geleden, starte heb ik veel steun ervaren van al degenen die op enigerlei wijze bij het onderzoek én de voorbereiding van het proefschrift betrokken waren.

Alvorens een aantal van hen bij naam te noemen, wil ik eerst de voor mij anonieme niet werkende en werkende mannen bedanken, die al voor de start van dit onderzoek de bereldheid toonden de interviewers van het Nederland oké panelonderzoek thuis te ontvangen en te woord te staam. Een groot deel van deze dissertatie berust op door hen verstrekte Informatie. Uiteraard ben ik bók de anonieme patiënten uit de huisartspraktijk erkentelijk voor hun medewerking aan het tweede deel van dit onderzoek.

Mijn drie promotores, Prof.dr. Cees de Geus, Dr. Frans Nijhuls en Prof.dr. Hans Philipsen dank ik hartelijk voor het 1 m mij gestelde vertrouwen en voor de prettige en deskundige begeleiding.

Cees de Geus, voorzitter van de vakgraep Hulsartsgeneeskunde, heeft mij de ruimte gegeven dit onderzaek te starten en te voltaolen. Cees, jouw persoonl1jke betrokkenheid en jouw adviezen heb ik altijd zeer op prijs gesteld. De lage drempel van jouw kamex maakte het gemakkelijk spontaan binnen te stappen om inzichten uit te wisselen en ontstane perikelen te bespreken. Ik ben je ook erkentelijk woor de geboden mogelijkheid om binnen het Registratienet Huisartsgeneeskunde (RNH), waarvan $11 j$ destijds voorzltter was, het hulsartsenpraktijkonderzoek te starten.

Het is niet toevallig dat mijn onderzoek in het deelproject verzelld raakte binnen "Arbeld en Gezondheld" waar Dr. Frans N1jhuls voorzltter is. Frans, jouw nuchtere aanpak heeft mij altijd geboeid en gestimuleerd. Het was voor mij verrassend te bemerken dat veel aspecten van 
het onderzoek in jouw ogen eenvoudiger waren dan in de mijne. Het was fijn te erwaren dat jif altijd bereid was, vaak op korte termijn, welk aspect van het onderzoek in welke fase dan ook, op te pakken en op een deskundige ijze in alle rust te bespreken. Deze gesprekken zet ik graag voort: samenwerking wet jou is méer dan de moeite waard.

Hans Philipsen heeft mij geattendeerd op de mogelijkheid het onderwerp "Gezondheid en niet werken" op basis van het Nederland oké materiaal. op te pakken. Het heeft mij niet verbaasd, dat bók dit onderwerp voor hem bekend terrein is. Dat samenwerking met hem leerzaan en prettig zou zijn, was mij reeds. lang bekend. Direct na mijn kandidaatsexamen (1969) had ik in Leiden al het genoegen onder zijn hoede de specialisaties (oftewel bijvakken) methoden en technieken van het sociaal wetenschappelijk onderzoek en medische soclologie te volgen. Hans, ik dank je hartelijk voor de geboden mogelijkheid opnieuw onder jouw haede mijn studie te vervalgen. Jouw creativiteit en sociologische verbeeldingskracht hebben mij steeds opnieuw geinspireerd. Je adviezen heb ik als zeer zinvol ervaren. Ik stel het ook op prijs dat je de mij ontbrekende onderzoeksassistentie lange tijd ter beschikking stelde. Dat onze samenwerking met het afronden van deze studie geenszins voorbij is, vormt voor mij een boeiend perspectief.

In dit dankwoord wil ik niet voorbijgaan aan de waardevolle bijdrage aan mijn proefschrift van de leden van de beoordelingscommissie. Ik was zeer verheugd dat ik twee leden ervan uit de "Leidse studieperiode" kende, namelijk Prof.dr. Jouke van der Zee en Mw.dr. Henrlütte Merens-Riedstra. Hun kritische opmerkingen én waardevolle suggesties waren er niet minder om. Jouke en Henriëtte, ik ben jullie zeer erkentelijk voor de nauwgezette wijze warop jullie het conceptproefschrift doorgelezen hebben en van commentaar voorzien. Ik hoop dat de hernieuwde contacten naar aanlelding van dit proefschrift een vervolg zullen hebben.

Prof.dr. Maria Drop was niet minder kritisch en minstens zo behulpzaam. Riet, $1 \mathrm{k}$ heb wederom bemerkt dat het "meedenken" niet het monopolie is van de NMB. Ik was en ben onder de indruk van de wijze waarop jij je van je taak als beoordelaar, en adviseur, gekweten hebt. Eer$11 \mathrm{jk}$ gezegd ligt jouw aanpak geheel in de lijn van onze eerdere con- 
tacten binnen en buiten de vakgroep Medische Soclologie. Ik voel mij dan ook vereerd dat jij deel uitmakte van de beoordelingscommissle. Voor Prof.dr. Andre Knottnerus was, en is het onderwerp "Gezondheld en niet werken" verre van onbekend. In zijn hoedanigheid van lid (ên voorzitter) van de beoordelingscomissie kwam dit tot uitdrukking in zijn kritisch commentaar en adviezen. Andrê, ik heb jouw bijdrage zeer op prijs gesteld, temeer ook ondat jij deel uitmaakt van dezelfde vakgroep als ik ên ondat jij als nieuwe voorzitter van het RNH niet geheel onbekend was met mijn onderzoek in het gezondheldscentrum 't Withuis. Sedert de tijd dat jij werkzaam bent in de vakgroep Huisartsgeneeskunde, heb 1 k gemerkt dat er sprake is van een nieuw elan, dat ook op mij zijn witwerking heeft.

Prof.dr.J. Persoon ben ik erkentelijk voor zijn bereldheid zitting te nemen in de beoordelingscomissie. Ik realiseer mij dat ook hif de nodige tijd en moeite geĩnvesteerd heeft om het concept-proefschrift te bestuderen. Prof. Persoon, hoewel ik u als Nijmegenaar persoonlijk nauwelijks ken, ben ik u niet minder ekentelijk voor de inspanningen die u zich getroost heeft om tot een oordeel over het proefschrift te komen.

Het aantal personen dat ik persoonlijk wil bedanken is nog verre van uitgeput. Zoals ik in het begin van mijn dankwoord al vermeldde, hebben velen aan dit proefschrift bijgedragen.

Mevrouw Ans Huyben van de vakgroep Verplegingswetenschappen bleek als onderzoeksassistente onvermoeibaar. Zij heeft mij met enthouslasme weg-wijs gemaakt in het Nederland oké materlaal. Met veel inzet heeft zif programma"s uitgeschreven en computer-uitdraaien gemaakt.

Ans, lk heb je bijdrage altijd zeer gewaardeerd. ook toen jij aan andere projecten je bijidrage moest leveren, stond jij altijd klaar on met mij gegevens aan de computer te ontfutselen. Wanneer het voor de voortgang van mijn onderzoek gewenst was, schroomde je niet in je vrije tijd je deskundige bijdrage te leveren.

Dr. Ruud Halfens was "op en top" deskundige van het Nederland Oke panelonderzoek "leefwijze en subjectieve gezondheid". Vlak voor de definitleve start van dit onderzoek én daarna heeft hij mij ingewijd 
In de opbouw van het naterial en de computermatige aspecten ervan. Ruud, ik ben je exkentelijk voor je getoonde bereidheid mij van advies te dienen, anneer ik hierom vroeg.

De heer Henk Lebens zorgde voor een nlet te onderschatten rode draad In dit onderzoek. Ik stond altijd verbaasd dat hij behalve voor vele andere onderzoekers binnen de vakgroep Medische Sociologie, ook voor my $j$ altijd weer ruinte wist te maken om of adviezen te geven bf computer-uitdrailen te verzorgen. Ondanks zijn vaak drukke werkzaameden, wist hij een zekere rust uit te stralen. Tevens om die reden was het goed toeven met hem. Herk, $i k$ heb je leren kennen als een bijzonder mens. Ik begrijp nog niet hoe het je lukte om mij altijd zeer snel de helpende hand te bieden. Met grote vaardigheid en deskundigheid wist jij ledere keer opnieuw de computer te mennen. ook je levenswijsheid dwingt bij mij bewondering af.

Met de heer Henk Lebens ben $1 k$ bij de vakgroep Medische Sociologie beland. Vanaf het begin van mijn werkzaamheden aan de RL, heb ik in deze wakgroep mogen participeren. In deze vakgroep heb ik ervaren hoe belangrijk goede persoonlijke verhoudingen zijn voor de onderlinge samenwerking en de productiviteit.

Tk ben Dr. Jos Diederiks, plaatsvervangend voorzltter van deze vakgroep, en Drs. Jan Joosten zeer erkentelijk voor de geboden mogelijkheden met hen ultgebreld van gedachten te wisselen over voetangels en klemmen van dit (en ander!) onderzoek.

Jos, ik hoop dat onze samenwerking in de toekomst op dezelfde wijze voortgezet wordt. Ik ervaar deze als zeer wardewol; ik ben je erkentelljk voor de doordachte adviezen.

Jan, de contacten met jou waren niêt zonder wetenschappelijke en persoonlifke betekenis voor mij. Ons verblijf in dezelfde kamer gaf mij de mogelijkheid vele ervaringen uft te wisselen over en naar aanleiding van dit en ander onderzoek. De door jou steeds opnieuw getoonde bereidheid om met mij problemen te doorgronden, hanteerbaar te maken dan wel op te lossen, heb ik uitdrukkelijk gewaardeerd. Ik verheug mij op de voortzetting wan onze contacten.

Alle overige leden van de vakgroep Medische Socialogie ben ik eveneens erkentelijk voor de geboden emotionele en praktische steun. ook dank ik met name Luc de Witte voor het grondig doornemen en corrigeren van de eindtekst van de dissertatie. 
Mijn collega"s bij de vakgroep Huisartsgeneeskunde ben ik eveneens zeer erkentelijk voor de geboden praktische en emotionele steun. Mevrouw Bep Köhlen heeft als onderzaeksassistente van het Registratienet Huisartspraktijken (RNH) ongetwijfeld ervaren dat bok aan dit onderzoek wel eens behoorlijk taaie en saile kanten zitten, naast Inspirerende en zelfs uitdagende kanten. Haar volharding en opgeruimdheid hebben in belangrijke mate ertoe bijgedragen dat het onderzoek in de huisartspraktijk toch nog binnen redelijke termijn afgerond kon worden. Bep, ik wil ook jou bedanken voor je deskundige en enthousiaste inzet.

Drs. Nico Comans heeft als socioloog vooral zijn sporen in het huisartspraktijk-onderzoek gedeelte nagelaten. Hij is vanaf het begin betrokken geweest bij dit deel van het onderzoek; hij heeft daaraan een belangrijke bijdrage geleverd. Nico, zonder je bijdrage was dit deel anzienlijk later gereed gekomen. Jouw snelle en accurate manier van werken, getuigend van een groot inzicht, heeft mij geImponeerd. Ik denk graag terug an de vele reizen die wij gezamenlijk naar NoordLimburg makten.

Drs. Jos Hendriks schroomde niet om desgevraagd adviezen te geven inzake automatiseringsperikelen en allerlei hand- en spandiensten te verlenen. Mevrouw Ine Siegelaer-Gerardu en de heer Jimmy Tatipata hebben vele teksten van het proefschrift uitgetypt. Mevrouw Fien van Deurse sprong sons ook in als de nood hoog was. Paul Zwietering, huisarts, reikte van tijd tot tijd nieuwe literatuur aan en screende de literuurlijst. Drs. Rüdiger von Höfen heeft zich gedurende het eerste jaar van dit onderzoek vele inspaningen getroost om de basis te leggen voor de patiëntenformulieren.

Ook jullie bedank ik voor de onmisbare bijdrage. Alle huisartsen van het RNH ben ik erkentelijk voor de ultgebreide excercities thet de RFE en later de ICPC. Dank $z i j$ hun bijdrage is de bas 1 s gelegd voor een betrouwbaar, hanteerbaar en adequat classificatiesysteem. In dit kader mag aan de zinvolle samenwerking van destijds met Prof.dr. Henk Lambierts niet voorbij gegaan worden.

Graag wil ik in het bijzonder nog even stilstaan blj de bijdrage van mevrouw Trudie Seegers, onderzoeksassistente in de vakgroep Huisartsgeneeskunde. Vanaf het moment dat de eerste concept-teksten gereed 
kwamen, heeft zij deze op de tekstwerwerker ingetypt. Ik heb verzuimd vast te stellen hoeveel concept-versies van de onderscheiden hoofdstukken uitgetypt zijn; het moeten ex vele geweest zijn. Toen zij van functie veranderde en onderzoeksassistente werd, was ik zeer verheugd dat $z 1 j$ bereld bleek de teksten te verzorgen tot het moment dat het proefschrift gereed zou zijn.

Trudie, ik heb je bijdrage altijd zeer gewaardeerd. Voor je snelle, accurate en kritische wijze van werken heb ik alle bewondering. Je adviezen over taalgebruik en compositie ervoer ik als waardevol. Je bijdrage is het proefschrift ten goede gekomen.

Indrukwekkend was de aanpak van twee computerdeskundigen van de vakgroep Medische Informatica en Statistiek (MIS), de heren Francois Dupuits en Frits Schoonbrood. Zij gingen enthousiast aan de slag, nadat hun vakbaas Prof.dr. Arie Hasman geopperd, had dat het invoeren van de probleemlijsten, met behulp van speciale computerprogramma's, het project zou bespoedigen en tot meer betrouwbare resultaten zou leiden. Dit laatste is zeker het geval, het eerste durf ik te betwijfelen. Niettemin realiseer ik milj dat de opgedane ervaringen wardevol $z 1 j n$ voor het Registratienet Hulsartspraktijken.

Frits en Francols, hartelijk bedankt voor jullie deskundige bijdrage en niet aflatende inzet om in geval van storingen met de apparatuur steeds weer opnieuw naar Venlo op en neer te rijden.

ook de heer Job Metsemakers, huisarts, w11 ik niet onvernoemd laten voor zijn inspanningen om de Venlose huisartsen wegwijs te maken in de probleemgeorlënteerde registratie en de ICPC. Job, ik ben je ook erkentelljk voor het screenen van de probleemlijsten.

De medewerkers van het gezondheidscentrum ' $t$ Withuls hebben volgens mijn laatste informatle de computer-vuurdoop toch nog overleefd. Ik wil In de eerste plaats de heren Dr. Remy van der Grinten en Jean Muris (hulsartsen) en José Bijker (coördinator en vliegende keep) bedanken woor hun belangrijk aandeel in het praktijkonderzoek. De huisartsen Fons Receveur, Prof.dr. Harry Crebolder, Tonny van Kessel en Roelof Heida ben ik eveneens erkentelijk voor hun inspanningen en doorzettingsvermogen. Omdat de assistentes de vinger an de pols hielden, lukte het toch nog bimmen redelijke termijn alle patiëntengegevens ten behoeve van het onderzoek in te voeren. Mevrouw Sonja Kui- 
pers, Corry Verstegen, Henriette Adelmeyer, Leonie Engelsma, Anneke Maas en Mieke Lamberts bedank ik hartelijk voor hun bijdrage. Mevrouw Arlanne van der Grinten sprong zo nu en dan in om snel en accurat de ontstane achterstand in te lopen. De gasturijheld van mevrouw Annemie van dex Grinten heb ik zeer gewardeerd. Arlanne en Annemie bedankt. Terugkerend naar Maasticht, wil $1 \mathrm{k}$ de enthouslaste ondersteuning van mevrouw Marlène Kruijen en Anne Wevers in herinnering brengen, alsmede die van Drs. Gregor Franssen. Deze medewerkers wan het MEMIC van de RL hebben alle medewerking gegeven bij het literatuuronderzoek. Marlene, Anne en Gregor, bedankt voor jullie bijdrage.

De heer Guus van Rooy, grafisch ontwerper, ben ik erkentelifk voor zijn frale kaftontwerp en zijn adviezen inzake de lay out.

De adviezen van Drs. Jan Klerckx, Prof.dr. Gerhard Saenger en mevrouw Riet Bartholomeus inzake de Engelse samenvatting heb ik zeer op prijs gesteld.

Aan het eind van dit dankwoord wil ik mijn moeder bedanken en mijn vader gedenken. Zij boden mij de gelegenheid de studie sociologie, die de basis van dit proefschrift vormde, te volgen.

ook Anne wil ik hartelijk bedanken voor de geboden steun tijdens de voorbereidingen van deze studie.

Klaske, Bregje en Jorn hebben mij in de voortgang van dit proefschrift gestimuleerd, ondanks het feit dat ik vaak een teruggetrokken bestaan leidde. Deze emotlonele steun heb ik zeer op prijs gesteld. 


\section{Curriculum Vitae}

Ik ben geboren op 15 april 1944 te Amsterdam, als zoon van Martien van der Horst en Hennie Jepkes. Gedurende mijn lagere school periode woonde ik achtereenvolgens in Bogor (Indonesië), Den Haag en Delft. De middelbare school volgde ik in Delft, waar ik in 1963 het diploma HBS-A behalde aan het Stanislascollege. Na militalre dienst en maritieme omzwervingen ging ik aan de Rijksuniversiteit Leiden sociologie studeren. In 1969 legde $1 \mathrm{k}$ het kandidatsexamen niet-westerse sociologie af, specialisatle Latijns Amerika. Ik vervolgde de studie Westerse soclologie met als hoofdvakken empirische en wijsgerige sociologie en als bijuakken medische sociologie en methoden en technieken van sociaal wetenschappelfjk onderzoek. In 1973 legde ik het doctoraalexamen af.

Van 1972 tot augustus 1974 was ik als stafdocent verbonden aan de Sociale Academie De Amstelhorn te Amsterdam-Buitenveldert, sectie Kaderopleiding voor verpleegkundigen.

In augustus $1974 \mathrm{kwam}$ ik als medisch sacioloog in dienst van de Rijksuniversiteit Limburg bij de vakgroep Huisartsgeneeskunde. Ik heb mij tot nu toe vooral actlef beziggehouden met onderwijs en onderzoek, ten behoeve van de Medische Faculteit en de Faculteit der Gezondheidswetenschappen. Publicaties betroffen de onderwerpen: verslaglegging/ registratie in de hulsartspraktijk, begeleiding van chronische zieken, compliance, patientenvoorlichting, democratisering in en van de gezondheidszorg, revalidatie en continutteit van zorg. 